
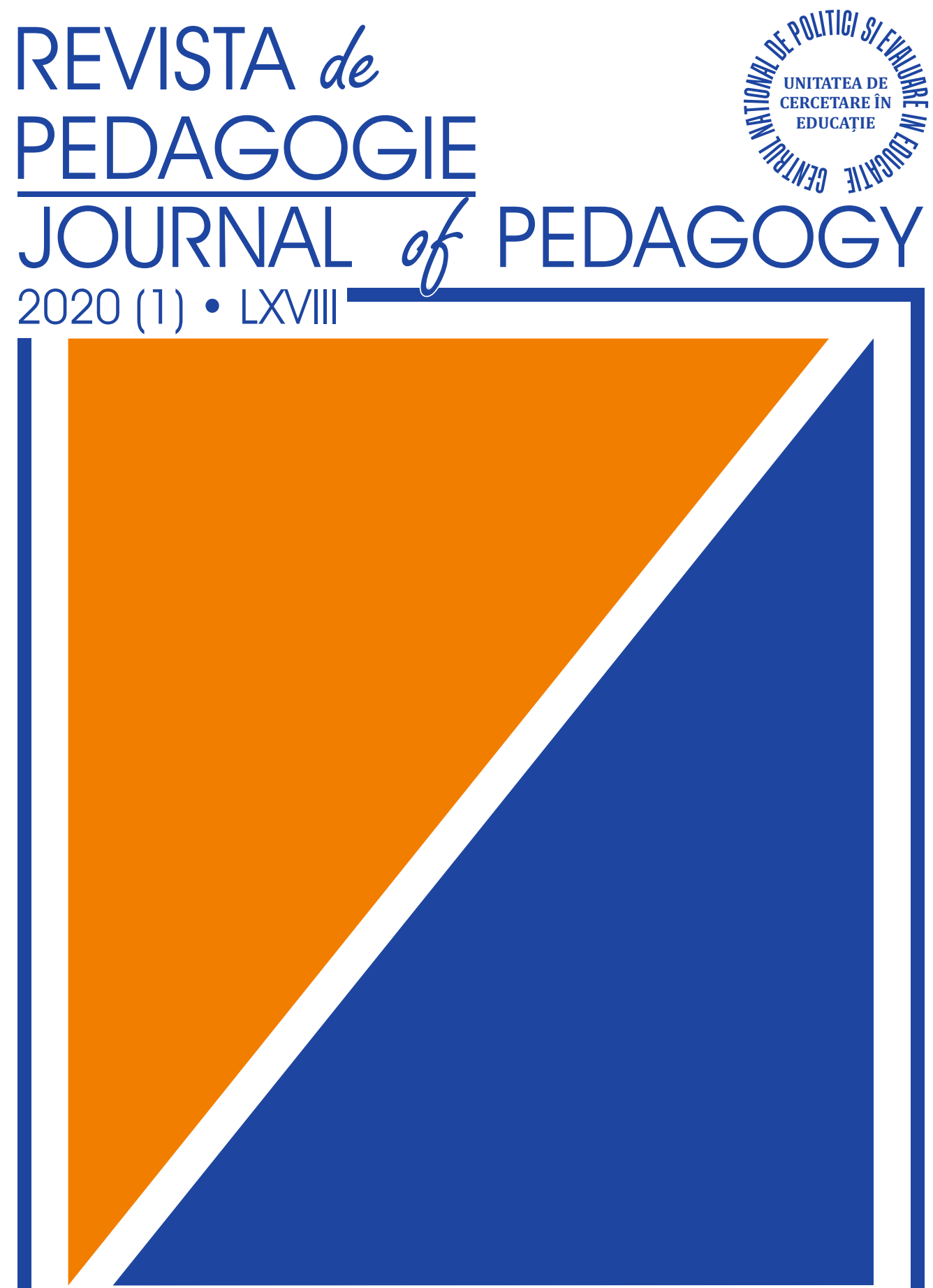
Prof. univ. emerit dr. Viorel NICOLESCU,

Universitatea din București, România

Prof. univ. dr. Constantin CUCOS,

DE

PEDAGOGIE

Universitatea „Al. I. Cuza” din Iași, România

\section{COLEGIUL DE REDACTIE:}

Prof. univ. dr. Gabriel ALBU, Universitatea de Petrol și Gaze din Ploiești, România

Cercet. şt. dr. Otilia APOSTU, C.N.P.E.E. - U.C.E.*, România

Acad. Alexandru BOBOC, Academia Română

Cercet. şt. dr. Laura Elena CĂPIŢ̆, C.N.P.E.E. - U.C.E. ${ }^{*}$, România

Prof. univ. dr. Carmen CREȚU, Universitatea „Al. I. Cuza” din Iași, România

Lector univ. dr. Alina Narcisa CRIȘAN, Universitatea Tehnică din Cluj-Napoca, România

Conf. univ. dr. Roxana ENACHE, vicepreședinte, Asociația „Academia Pedagogilor”, România

Prof. univ. dr. Irfan ERDOGAN, Universitatea din Istanbul, Turcia

Prof. univ. dr. Natasha Angelska GALEVSKA, Universitatea „Chiril și Metodiu” din Skopje, Macedonia

Prof. univ. dr. Dimitrios B. GOUDIRAS, Universitatea „Macedonia”, Salonic, Grecia

Cercet. şt. Atwell GRAHAM, Universitatea din Wales, Marea Britanie

Cercet. şt. dr. Irina HORGA, C.N.P.E.E. - U.C.E. ${ }^{*}$, România

Prof. univ. dr. Violeta MIRCHEVA, Institutul Național de Educație, Bulgaria

Prof. univ. dr. Ioan NEACŞU, Universitatea din București, România

Prof. univ. dr. Rodica NICULESCU, Universitatea „Transilvania” din Brașov, România

Prof. univ. dr. Aleksandra PEJATOVIC, Universitatea din Belgrad, Serbia

Prof. univ. dr. Rossitsa PENKOVA, Universitatea „K. Ohridski” din Sofia, Bulgaria

Lector univ. dr. Ana-Maria Aurelia PETRESCU, Universitatea „Valahia” din Târgoviște, România

Prof. univ. dr. Dan POTOLEA, Universitatea din București, România

Prof. univ. dr. Athina SIPITANOU, Universitatea „Macedonia”, Salonic, Grecia

Prof. univ. dr. Emil STAN, Universitatea de Petrol și Gaze din Ploiești, România

Acad. Alexandru SURDU, Academia Română

Prof. univ. dr. Nikos TERZIS, Universitatea „Aristotel”, Salonic, Grecia

Cercet. şt. dr. Simona Luciana VELEA, C.N.P.E.E. - U.C.E.*, România

Prof. univ. dr. Pavel ZGAGA, Universitatea din Ljubljiana, Slovenia

${ }^{*}$ Centrul Național de Politici și Evaluare în Educație - Unitatea de Cercetare în Educație

RESPONSABILI DE NUMĂR:

Cercet. șt. Oana IFTODE, Cercet. şt. dr. Ancuța PLĂEȘU

REDACTOR:

Miruna Luana MIULESCU

\section{TEHNOREDACTARE COMPUTERIZATĂ ȘI TIPAR:}

Vlad PASCU

\section{BROȘARE:}

Constantin CHIȚU

Print ISSN: 0034-8678

Online ISSN: 2559-639X

Indexare BDI: CEEOL, Citefactor, Crossref, De Gruyter (IBZ and IBR), DOAJ, EBSCO, ERIH Plus, Google Academic și Ulrichweb. Articolele care conțin subiecte despre învățământul superior pot fi indexate și în HEDBIB.

Informațiile și punctele de vedere prezentate în contribuțiile publicate sunt cele ale autorului (autorilor) și nu reflectă neapărat opinia oficială a Revistei de Pedagogie.

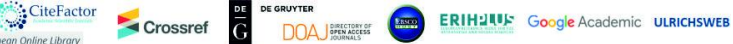

ADRESA REDACȚIEI: Str. Ştirbei Vodă Nr. 37, sector 1, București 010102

Tel.: 021-314.27.83 Fax: 021-312.14.47

E-mail: revped@ise.ro Pagina web: http://revped.ise.ro

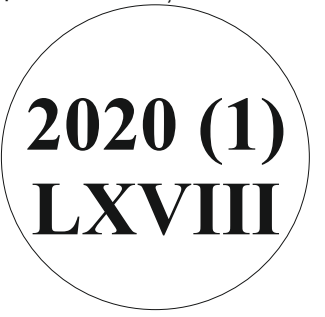




\section{REVISTA DE PEDAGOGIE/ JOURNAL OF PEDAGOGY 2020 (1) • LXVIII}





\section{CUPRINS}

Tinerii vulnerabili şi inegalitatea socială. $\mathrm{O}$ analiză a situa iei sociale a

tinerilor NEET în România

Sebastian $O C$

Slaba calitate a procesului educa ional - cauza principală a părăsirii timpurii a şcolii ...... 31

Adela Mihaela $\breve{A R A N U}$

Pozi ionarea elevilor cu status socio-economic scăzut fa ă de învă area

şcolară - studiu de caz

Octavia BORS

Resurse sociale ale şcolilor din zonele defavorizate 71

Aura $A B \breve{A} R \breve{A}$, Ovidiu BUNEA

Prezen a experien elor vie ii, a tradi iilor şi a istoriei romilor în manualele româneşti - o analiză a con inutului din perspectiva justi iei sociale

Cristina TUNEGARU

„Mersul pe sârmă”: provocări întâlnite de profesorii debutan i în practica didactică ..... 115

Miruna Luana MIULESCU

Competen ele de cetă enie digitală ale viitorilor profesionişti în educa ie. Abordări în

contextul măsurilor de distan are socială generate de răspândirea Covid-19

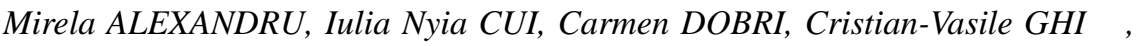
Mihaela-Elena IONICĂ, Alina Andreea MUŞESCU, Veronica Lulu Viorica SEREA, Leyla SAFTA-ZECHERIA

O privire critică asupra portofoliului ca instrument pentru învă area reflectivă:

percep ia studen ilor

Elena MARIN

Efectele activită ilor extracurriculare şi extraşcolare asupra performan ei şcolare 173 Andrea BARABÁS 
Autoeficien a cu privire la deprinderile academice şi aşteptările legate de absolvirea facultă ii ca predictori ai satisfac iei fa ă de domeniul de studiu ales şi ai inten iei de renun are la facultate

Raluca LIVIN I, Dragoş ILIESCU

Inducerea ruşinii şi vinovă iei în conducerea şi facilitarea actului de învă are al şcolarului mic: rela ia cu dezvoltarea simptomatologiei asociate anxietă ii

Leti ia ANCULETE, Gra iela SION 


\section{CONTENTS}

Vulnerable Young People and Social Inequality. An Analysis of the Social

Situation of NEETs in Romania

Sebastian $O C$

Low Quality of the Educational Process - Main Cause of the Early School Leaving ...... 31 Adela Mihaela $\breve{A R A N U}$

Students with Low-Socioeconomic Status and Their Representations on

School Learning. A Case Study 51

Octavia BORS

Social Resources of Schools from Disadvantaged Areas 71

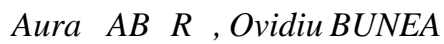

The Presence of Roma Life's Experiences, Traditions and History in the

Romanian Textbooks - A Content Analysis from a Social Justice Perspective

Cristina TUNEGARU

Walking the Tightrope: Challenges Encountered in Novice Teachers' Practice

\section{Miruna Luana MIULESCU}

Digital Citizenship Competences of Future Education Professionals. Approaches in the Context of the Covid-19 Social Distancing Measures

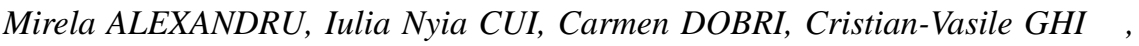
Mihaela-Elena IONICĂ, Alina Andreea MUŞESCU, Veronica Lulu Viorica SEREA, Leyla SAFTA-ZECHERIA

A Critical Look at the Portfolio as a Tool for Reflective Learning:

Students' Perceptions

Elena MARIN

The Effects of Extracurricular and Extraschool Activities on School Performance 173 Andrea BARABÁS 
Academic Skills Self-Efficacy and College-Going Outcome Expectations as

Predictors of Undergraduates' Satisfaction with Their Chosen Area of Study and

Dropout Intentions

Raluca LIVIN I, Dragoş ILIESCU

Inducing Shame and Guilt when Leading and Facilitating Learning in Young School

Children: the Relationship with Anxiety-associated Symptomatology

Leti ia ANCULETE, Gra iela SION 


\title{
TINERII VULNERABILI ŞI INEGALITATEA SOCIALĂ. O ANALIZĂ A SITUA IEI SOCIALE A TINERILOR NEET ÎN ROMÂNIA
}

Sebastian oc*

\author{
Şcoala Na ională de Studii Politice şi Administrative, \\ Institutul de Cercetare a Calită ii Vie ii, Academia Română, \\ Bucureşti, România \\ sebastian.toc@politice.ro,sebastian.toc@iccv.ro
}

\section{Rezumat}

În acest articol analizez situa ia tinerilor vulnerabili din România, cu accent pe tinerii NEET, una dintre categoriile aflate în risc de excluziune socială în spa iul european. Scopul este de a în elege situa ia tinerilor care se află în situa ii de vulnerabilitate, împreună cu problemele specifice sistemului de învă ământ, pie ei muncii şi care decurg din (in)eficien a sistemului de protec ie socială. Prima parte a lucrării are ca scop descrierea inegalită ilor sociale la care sunt expuşi tinerii din România. A doua parte propune analiza descriptivă a profilului tinerilor NEET din România şi din Uniunea Europeană. Realizez analize secundare utilizând date furnizate de Eurostat pentru a contura un profil al tinerilor NEET din România, date pe care le completez cu informa ii calitative ob inute de la tineri NEET şi asisten i sociali, prezentate într-un raport al Institutului de Ştiin e ale Educa iei (ISE, 2015). A treia parte se concentrează pe problemele cu care tinerii se confruntă la ieşirea din sistemul de învă ământ, precum şi pe inegalită ile de pe pia a muncii şi pe aspecte ce in de eficien a transferurilor sociale în România. Ultima parte este dedicată prezentării unor programe de tineret în contextul austerită ii.

Cuvinte-cheie: inegalită i sociale, pia a muncii, politici de tineret, tinerii NEET, vulnerabilitate.

Asist. univ. dr., Şcoala Na ională de Studii Politice şi Administrative, Bucureşti, România. Cercetător, Institutul de Cercetare a Calită ii Vie ii, Academia Română, Bucureşti, România. 


\section{Abstract}

In this article, I analyze the situation of vulnerable young people in Romania, with a focus on NEETs, one of the categories at risk of social exclusion in the European countries. The main objective is to understand the vulnerabilities of young people in relation to the outcomes of the education system, labor market, and the efficiency of the social protection system.

The first part of the paper aims to describe the social inequalities to which young people in Romania are exposed. The second part proposes a descriptive analysis of the NEETs profile in Romania and the European Union. I use quantitative data provided by Eurostat to outline the diversity of NEETs in Romania, complemented with secondary qualitative data collected from NEETs and social workers from a research report published by the Institute of Educational Science in Romania (ISE, 2015). The third part focuses on the problems that young people face when leaving the education system, as well as on labor market inequalities and issues related to the efficiency of social transfers in Romania. The last part aims to analyzing Youth programs in the context of austerity after the global economic crisis of 2008.

Keywords: labor market, NEETs, social inequalities, vulnerability, youth programs.

\section{Inegalitatea socială şi grupurile vulnerabile în România}

Creşterea inegalită ilor sociale a fost considerată una dintre consecin ele inevitabile ale transformărilor structurale din România ultimilor 30 de ani. Acest caracter de ,inevitabilitate" a generat o preocupare minoră pentru reducerea acestora. Studii precum cele ale lui Dragolea (2016), Hatos (2006), Zamfir (2012) sugerează că în perioada de tranzi ie nu a existat o preocupare politică reală pentru reducerea inegalită ilor sociale. Aşadar, în perioada de tranzi ie postsocialistă, reducerea inegalită ilor prin politici sociale şi salariale nu a constituit o prioritate, iar după aderarea la Uniunea Europeană lucrurile nu s-au schimbat semnificativ. Una dintre consecin ele vizibile a fost că, cel pu in în ceea ce priveşte indicatorii care măsoară inegalită ile de venituri, România se află printre ultimele locuri în Europa: indicele GINI ${ }^{1}$ a crescut de la 24 în 1989 (Zamfir, 2012, p. 26) la 35,1 în 2018 (Eurostat, indicator ilc_di12); raportul S80/S20² a crescut de la 4,5 în 2000 la 7,2 în 2018) (Eurostat, indicator ilc_di11). Inegalită ile pot fi ilustrate în România nu numai prin inegalitatea de venituri, ci şi prin prisma accesului inegal la servicii ce influen ează calitatea vie ii indivizilor: studii sectoriale privind accesul inegal la educa ie (Florian \& oc, 2018; oc, 2018), sănătate 
(Precupe u \& Pop, 2017), locuire (Briciu, 2016), pia a muncii (Domnişoru, 2014; Dragolea, 2008, 2016) sunt ilustrative. Pe de-o parte, inegalită ile sunt determinate de structura economiei, pia a muncii din România fiind puternic segmentată şi dominată de locuri de muncă cu salarii scăzute. De exemplu, în anul 2018, aproape jumătate dintre contractele de muncă încheiate aveau valoarea salariului minim sau erau sub salariul minim, cele mai multe fiind oferite de angajatori priva i (2,5 milioane din totalul de 3 milioane contracte de muncă mai mici sau egale cu salariul minim pe economie) (Monitorul Social, 2018). Pe de altă parte, există decalaje importante între mediul rural şi urban, precum şi importante diferen e de dezvoltare între regiuni. Există, totodată, inegalită i de acces la servicii publice între etnicii romi şi cei care apar in grupului etnic majoritar (Ra , 2010). De asemenea, chiar dacă diferen ele salariale între femei şi bărba i au scăzut în România, există în continuare inegalită i de gen pe pia a muncii, cauzate, în principal, de faptul că este mai probabil ca femeile să aibă ocupa ii mai slab remunerate (Domnişoru, 2014; European Commission, 2018). Suprapunerea mai multor tipuri de inegalită i a fost rar luată în considerare în procesele de constituire a politicilor publice, analiza inegalită ilor şi disparită ilor sociale dintr-o perspectivă intersec ională (Crenshaw, 1991) fiind rar întâlnită în România (Dragolea, 2016, p. 84). De altfel, recomandările Eurofound (2013) pentru studiul inegalită ii sociale sunt de a urmări cel pu in trei dimensiuni:

- inegalită i la nivelul rezultatelor (de ex., educa ionale, ocupa ionale, venituri etc.);

- inegalită i în privin a autonomiei indivizilor de a face alegeri/lua decizii;

- inegalită i de tratament (de ex., discriminare).

O problemă semnificativă care accentuează inegalită ile este, în toate ările europene, gradul scăzut de ocupare a for ei de muncă în rândul tinerilor. Criza economică din 2008 a afectat în mod particular tinerii, fiind dezvoltate strategii care să le faciliteze re(integrarea) pe pia a muncii în statele membre. Problema continuă să persiste şi astăzi, ponderea popula iei tinere inactive la nivelul tuturor ărilor UE şi criza şomajului în rândul tinerilor amenin ând modelul social european şi coeziunea socială (Eurofound, 2016). Potrivit datelor din 2018, în România, procentul tinerilor NEET ${ }^{3}$ cu vârste cuprinse între 15-24 ani era de 14,5\%, fa ă de 10,5\% media UE28. Iar în situa ia în care creştem intervalul de vârstă la 15-29 de ani, procentele sunt şi mai ridicate: $17 \%$ în România, peste media UE28 care e 12,9\% (Eurostat, 
indicator [edat_lfse_20]). Mai mult, România este ara în care sărăcia în rândul tinerilor cu vârste cuprinse între 15 şi 29 ani a fost constant peste 40\% începând cu 2007, cu excep ia anului 2018, când 36,4\% dintre tineri se aflau în risc de sărăcie sau excluziune socială (27,4\% în UE28), lucru care afectează participarea la educa ie şi ob inerea unui loc de muncă (Eurostat, indicato [ilc_peps01]). Aşadar, în contextul îmbătrânirii popula iei, a scăderii natalită ii şi a fenomenului migra iei în străinătate pentru muncă, inclusiv a tinerilor (Sandu, 2010), precum şi în contextul globalizării şi avansului tehnologic (Brown \& Lauder, 2010), există riscul apari iei unui dezechilibru între persoanele active contribuabile şi cele inactive.

Reducerea numărului de tineri NEET reprezintă o prioritate pentru toate ările europene. Fiind o categorie eterogenă de indivizi, este dificilă elaborarea de politici care să aibă un impact pozitiv asupra problemelor specifice ale diverselor categorii de tineri. De altfel, potrivit ultimului raport Eurofound (2016), tinerii NEET pot fi împăr i i în şapte subgrupuri, cu două mai multe decât în raportul precedent (2012), însă criteriul important rămâne împăr irea între grupul vulnerabil şi cel nevulnerabil, ultimul având şanse mai mici de excluziune socială.

Acest articol propune în elegerea situa iei tinerilor vulnerabili într-un context mai larg, adică în rela ie cu problemele sistemului de învă ământ românesc şi ale pie ei muncii din România şi în legătură cu programele menite să sprijine tinerii. Analiza este relevantă în contextul riscului ridicat de excluziune socială pe care îl experimentează persoanele care nu sunt ocupate. De asemenea, având în vedere că diversitatea categoriei tinerilor NEET a fost recunoscută la nivel guvernamental, este dezirabilă identificarea politicilor adecvate care să sus ină incluziunea socială a tinerilor vulnerabili. Pe această temă a existat un interes politic în ultimii ani în România şi în celelalte state membre. Au fost implementate programe sub umbrela Garan iei pentru Tineret ${ }^{4}$, care nu inteşte doar tinerii NEET, dar îi are în vedere în programele destinate creşterii calită ii ocupării, educa iei continue, sistemului de ucenicie şi formare, precum şi programe în cadrul Ini iativei pentru Ocuparea Tinerilor, ${ }^{5}$ prin care au fost alocate fonduri exclusiv pentru reducerea numărului de tineri NEET. 
Începând cu anul 2010 a fost construit un indicator cu scopul măsurării procentului de tineri NEET în fiecare ară din UE, fiind considerat mai relevant pentru situa ia tinerilor din prezent, comparativ cu indicatorii standard care măsoară participarea pe pia a muncii, mai ales în contextul vulnerabilită ii acestora pe pia a muncii, în condi iile crizei economice (Eurofound, 2016). Este importantă în elegerea termenului de NEET şi evitarea folosirii eronate a acestuia. De exemplu, nu discutăm numai despre tineri dezavantaja i social, existând o diversitate importantă în interiorul categoriei; o altă utilizare eronată este folosirea sintagmei ,tineri care nu vor să muncească” care duce la stigmatizarea acestei categorii; tinerii NEET nu trebuie în eleşi numai prin prisma statutului lor în raport cu pia a muncii, ci şi prin prisma altor factori precum responsabilită i familiale, dizabilitate, boală, care îi determină să nu lucreze (ibid.). Potrivit Eurofound (2012, 2016), cea mai bună clasificare a tinerilor NEET este între tineri vulnerabili şi tineri mai degrabă nevulnerabili. Spre deosebire de ultimii, primii sunt caracteriza i prin faptul că pot utiliza un stoc limitat de capital economic, social, cultural şi se află în risc de marginalizare socială. Cei mai mul i tineri NEET din România fac parte, însă, mai degrabă din prima categorie, făcând dificilă găsirea unor solu ii pentru ieşirea din zona de risc de sărăcie sau excluziune socială.

\section{Profilul tinerilor NEET in România şi Uniunea Europeană}

Cele mai multe ări din Europa se confruntă cu problema tinerilor inactivi care nu se află nici pe pia a muncii, nici în sistemul educa ional sau în alte tipuri de formare. Datele despre România din această sec iune vor fi analizate comparativ cu media UE28. In contextul acestui studiu, compara ia şi raportarea la mediile diverselor grupuri de ări este relevantă prin prisma persisten ei problemei ponderii popula iei tinere inactive la nivelul tuturor ărilor UE şi a şomajului în rândul tinerilor (Eurofound, 2016).

Dacă în anii aderării şi integrării în Uniunea Europeană a fost înregistrată o scădere substan ială a tinerilor NEET, începând cu anul 2009 a urmat o creştere până la 18\%. O ară similară cu România din punct de vedere socioeconomic, Bulgaria, are un procent asemănător, aproximativ 2 din 10 tineri fiind într-o astfel de situa ie. Croa ia este, de asemenea, una dintre ările foste socialiste cu o situa ie asemănătoare României sau Bulgariei. 
Tabelul nr. 1. Procentul tinerilor NEET cu vârste cuprinse între 15 şi 24 de ani

\begin{tabular}{|c|c|c|c|c|c|c|c|c|c|c|c|c|c|c|c|}
\hline & 2004 & 2005 & 2006 & 2007 & 2008 & 2009 & 2010 & 2011 & 2012 & 2013 & 2014 & 2015 & 2016 & 2017 & 2018 \\
\hline UE28 & 15.3 & 15.0 & 14.0 & 11.0 & 10.9 & 12.5 & 12.8 & 12.9 & 13.2 & 13.0 & 12.5 & 12.0 & 11.6 & 10.9 & 10.5 \\
\hline RO & 21.2 & 18.4 & 16.5 & 13.3 & 11.6 & 13.9 & 16.6 & 17.5 & 16.8 & 17.0 & 17.0 & 18.1 & 17.4 & 15.2 & 14.5 \\
\hline
\end{tabular}

Sursa: Eurostat, indicator [yth_empl_150]

Statele din zona mediteraneană s-au confruntat constant cu problema şomajului în rândul tinerilor, iar criza economică a generat o creştere substan ială a procentului de tineri şomeri, în special în Italia şi Grecia, dar şi în Spania şi Cipru. De asemenea, economia informală este dezvoltată în ările din sudul Europei, în special pentru tineri şi femei (Ferrera, 2010, p. 623). Aceasta este o posibilă explica ie pentru numărul mare de tineri şi tinere NEET în ările mediteraneene în contextul crizei economice.

Sub aspectul diferen elor de gen, în România, femeile au o probabilitate mai ridicată să fie NEET, comparativ cu bărba ii. Prin compara ie, diferen a între femei şi bărba i este mai scăzută la nivelul mediei UE28. Dintre ările europene, în cele mediteraneene, inegalită ile de gen sunt mai ridicate, în defavoarea femeilor. Acest lucru confirmă ideile conform cărora femeile au o prezen ă mai scăzută pe pia a muncii în aceste state, ca urmare a suplinirii rolului statului de către familie în asigurarea bunăstării şi a serviciilor de asisten ă socială (îngrijirea copiilor, bătrânilor, persoanelor cu dizabilită i etc.) (Ferrera, 2010). Excep ie face Spania care şi-a redus semnificativ diferen ele de gen în urma crizei economice, însă acest lucru s-a produs ca urmare a creşterii mai rapide a şomajului în rândul bărba ilor.

Tabelul nr. 2. Procentul tinerilor NEET cu vârste cuprinse între 15 şi 24 de ani (diferen e de gen)

\begin{tabular}{|c|c|c|c|c|c|c|c|c|c|c|c|c|c|c|c|}
\hline & 2004 & 2005 & 2006 & 2007 & 2008 & 2009 & 2010 & 2011 & 2012 & 2013 & 2014 & 2015 & 2016 & 2017 & 2018 \\
\hline EU28 (M) & 12.3 & 11.9 & 11 & 9.8 & 9.8 & 12.0 & 12.4 & 12.6 & 13.0 & 12.8 & 12.3 & 11.8 & 11.3 & 10.7 & 10.1 \\
\hline EU28 (F) & 18.3 & 18.1 & 17 & 12.2 & 12.1 & 12.9 & 13.2 & 13.3 & 13.4 & 13.2 & 12.7 & 12.3 & 11.9 & 11.2 & 10.9 \\
\hline RO (M) & 18.3 & 14.5 & 13 & 11.6 & 8.8 & 11.2 & 14.2 & 16.3 & 15.2 & 15.3 & 15.3 & 15 & 14.1 & 12.1 & 11.4 \\
\hline RO (F) & 24.2 & 22.4 & 20.1 & 15.1 & 14.5 & 16.8 & 19.2 & 18.7 & 18.5 & 18.7 & 18.8 & 21.4 & 20.8 & 18.4 & 17.8 \\
\hline
\end{tabular}

Sursa: Eurostat, indicator [yth_empl_150]

O altă caracteristică esen ială pentru în elegerea situa iei tinerilor NEET din România în raport cu pia a muncii, comparativ cu media ărilor europene, 
este ponderea şomerilor. Dacă în cazul mediei ărilor europene (UE28), raportul şomeri-inactivi (în total tineri NEET) este de $42 \%-58 \%$, în cazul României, ponderea tinerilor NEET inactivi este de aproximativ 70\%. Cei $30 \%$ şomeri nu trebuie confunda i cu şomerii care primesc indemniza ia de şomaj, în categoria celor din urmă intrând cei care nu au un loc de muncă şi care au căutat de muncă în mod activ în ultimele 4 săptămâni, sau cei care deja au găsit un loc de muncă pe care îl vor începe în următoarele trei luni. Procentul tinerilor inactivi este unul ridicat în România, însă aproape jumătate dintre tinerii NEET ar dori să muncească, indiferent dacă se află în căutarea unui loc de muncă sau nu (a se vedea Graficul nr. 2); acest procent este ceva mai scăzut, comparativ cu media UE28, unde aproximativ două treimi dintre tinerii NEET au declarat că ar dori să muncească. Mai mult, ieşirea din situa ia de NEET în cazul tinerilor cu vârste cuprinse între 15 şi 18 ani se poate face prin reînscrierea în învă ământ, acesta putând fi unul dintre motivele pentru care unii responden i declară că nu îşi caută sau nu sunt disponibili pentru a ocupa un loc de muncă.

\section{Graficul nr. 1. Raportul dintre şomeri şi inactivi în total tineri NEET cu} vârste cuprinse între 15 şi 24 (\%)

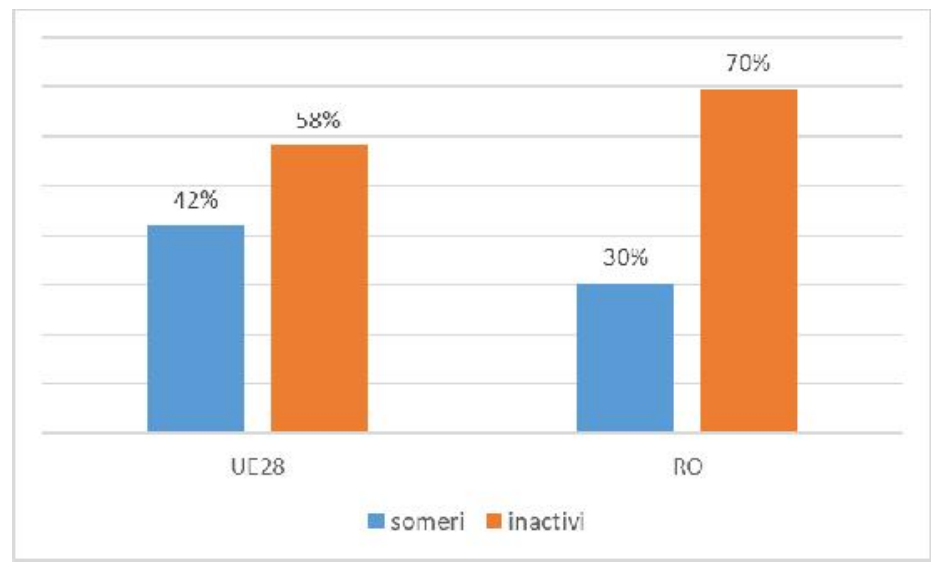

Sursa: Calcule proprii pe datele Eurostat pentru anul 2018, indicator [yth_empl_150]

Analizată dintr-o perspectivă de gen, situa ia este şi mai critică, atât în Europa (UE28), cât şi în România. Aproximativ 80\% dintre tinerele NEET din 
Graficul nr. 2. Raportul dintre cei care declară că sunt dispuşi să muncească şi cei care declară că nu sunt dispuşi să lucreze în economia formală, din total tineri NEET cu vârste cuprinse între 15 şi 24

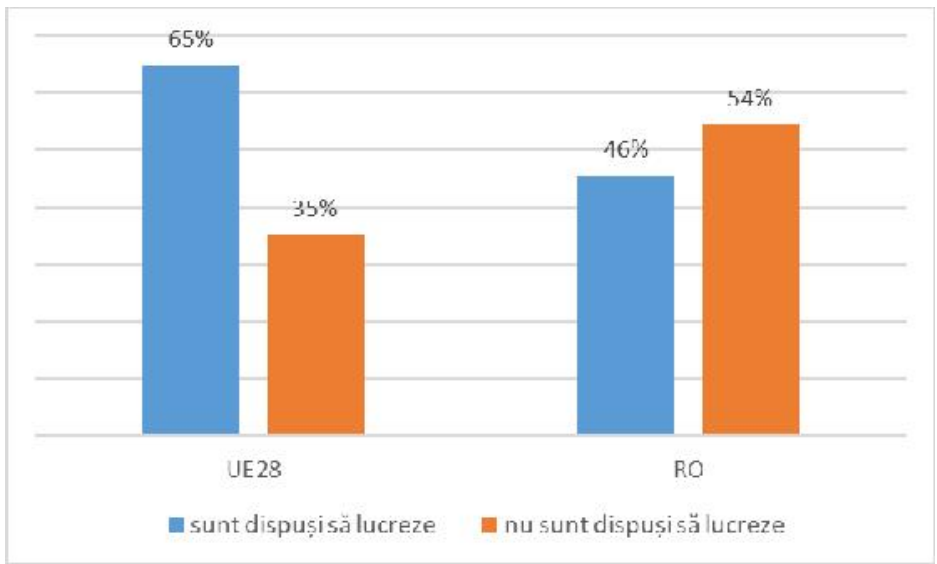

Sursa: Calcule proprii pe datele Eurostat pentru anul 2018, indicator [yth_empl_150]

România sunt inactive, comparativ cu media UE28 care este $66 \%$ (a se vedea Graficul 3). De asemenea, 66\% dintre tinerele NEET din România nu sunt dispuse a ocupa un loc de muncă, fa ă de $43 \%$ în UE28.

Graficul nr. 3. Raportul dintre şomeri şi inactivi din total tineri NEET de GEN FEMININ, cu vârste cuprinse între 15 şi 24

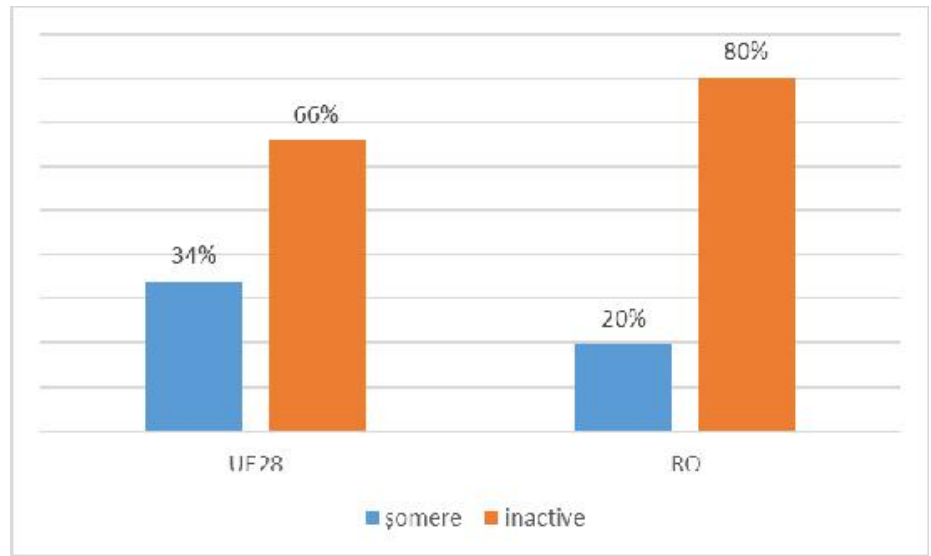

Sursa: Calcule proprii pe datele Eurostat pentru anul 2018, indicator [yth_empl_150] 
Graficul nr. 4. Raportul dintre persoanele care declară că sunt dispuse să muncească şi cele care declară că nu sunt dispuse să lucreze în economia formală, din total tineri NEET de gen feminin cu vârste cuprinse între 15 şi 24

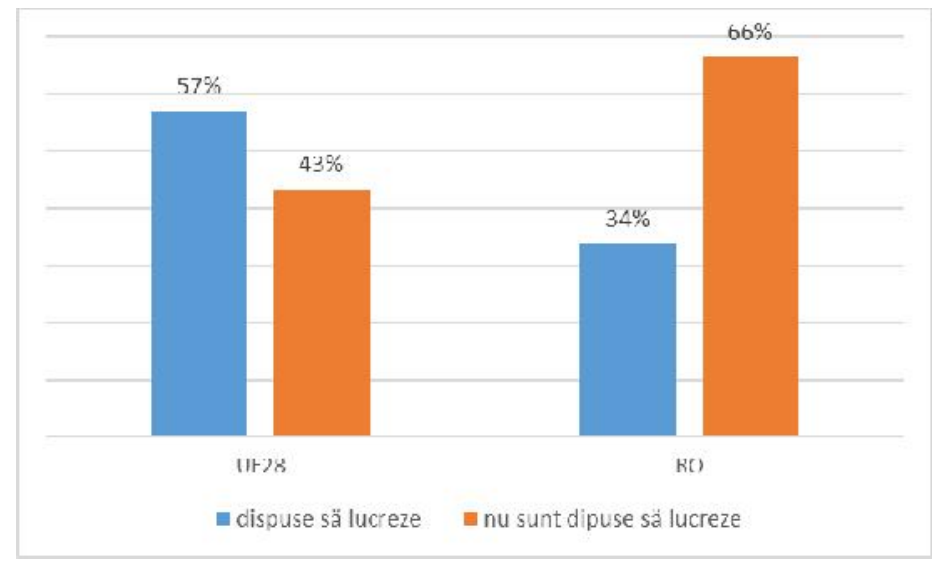

Sursa: Calcule proprii pe datele Eurostat pentru anul 2018, indicator [yth_empl_150]

Este important de men ionat de asemenea faptul că, spre deosebire de media UE28 unde nu există diferen e majore în func ie de gradul de urbanizare, în România, tinerii NEET au o probabilitate mai ridicată să locuiască în rural sau urban mic şi suburbii (Eurostat, indicator [edat_lfse_29]). În ceea ce priveşte nivelul de şcolaritate al tinerilor NEET, nu există diferen e semnificative între aceştia, ponderea tinerilor NEET fiind asemănătoare între cele 3 categorii: maxim gimnaziu, liceu şi postliceală, respectiv studii universitare (Eurostat, indicator [edat_lfse_21]). Pe scurt, următoarele caracteristici sunt esen iale pentru a în elege contextul în care tinerii ajung să se afle în categoria NEET:

- Locuiesc mai degrabă în mediul rural, oraşe mici sau suburbii, decât în urban.

- Nivelul de şcolaritate nu este un factor esen ial care influen ează probabilitatea de a fi în categoria NEET, aceştia sunt distribui i aproape egal în grupurile cu nivel de şcolaritate scăzut, mediu sau ridicat.

- Jumătate dintre tinerii NEET ar dori să muncească, indiferent dacă se află sau nu în căutarea unui loc de muncă.

- Diferen ele de gen sunt importante, ponderea tinerelor NEET fiind mai 
mare comparativ cu cea a bărba ilor. De asemenea, este mai probabil ca femeile NEET să fie inactive şi nedispuse pentru a ocupa un loc de muncă, comparativ cu bărba ii.

Profilul tinerilor NEET poate fi completat şi de studii cantitative, precum cel al lui Plăeşu şi al ii (2015), care estimează şi un număr semnificativ de tineri de etnie romă, tineri din comunită i dezavantajate, afectate de sărăcie. Realizat în regiunile Sud-Muntenia şi Sud-Vest Oltenia, studiul sugerează că problemele tinerilor NEET pot fi în elese în contextul lipsei unei ,,infrastructuri care să genereze oportunită i de ocupare" (Plăeşu et al., 2015, p. 127). Oportunită ile sunt mult mai limitate pentru tinerii NEET din mediul rural, probabilitatea ca aceştia să se afle în situa ie de deprivare materială fiind ridicată (ibid.). Mai mult, experien a în general negativă a tinerilor NEET cu institu iile şi serviciile publice de educa ie, formare şi ocupare, dublate de practici discriminatorii, a generat mai degrabă o lipsă de încredere în institu ii publice (ibid., p. 132).

O altă problemă importantă referitoare la tinerii NEET cu vârste cuprinse între 15-24 de ani din România este faptul că mai mult de $25 \%$ sunt dificil de identificat, practic sunt, ,invizibili”: nu sunt înregistra i la agen ii de for ă de muncă, au un nivel de şcolaritate scăzut şi nu au experien ă în munca formală (Eurofound, 2016). Un studiu al Institutului de Ştiin e ale Educa iei (ISE, 2015) sugerează, de asemenea, că în România există / se manifestă o apreciere nefavorabilă a consilierilor din cadrul Agen iilor locale şi jude ene pentru ocuparea for ei de muncă (AJOFM/ALOFM) fa ă de tinerii inactivi sau afla i în căutarea unui loc de muncă prin intermediul acestor agen ii. Consilierii au utilizat atribute individuale, în general negative, pentru a explica numărul mare de tineri care fie nu au un loc de muncă, fie nu se află într-o formă de formare: tinerii sunt descrişi ca ,neserioşi” şi ,,dezinteresa i în a-şi găsi un loc de muncă”, pu ini având o ,, intă în via ă”, ,,dependen i de părin i”, „nu sunt atraşi de şcoală dar îşi doresc bani” (ISE, 2015, pp. 50-51).

\section{Tinerii vulnerabili - ieşirea din sistemul de învă ământ şi dificultă ile de integrare pe pia a muncii}

Problema tinerilor afla i în situa ie de vulnerabilitate trebuie în eleasă şi în contextul deficien elor sistemului de învă ământ din România. Monitorul 
Educa iei şi Formării actualizează anual indicatorii relevan i din domeniul educa ional (Comisia Europeană, 2017, 2018, 2019). Potrivit rapoartelor, România se află pe ultimele locuri în Uniunea Europeană la majoritatea indicatorilor care ilustrează situa ia educa iei. În anul 2018, procentul din PIB alocat educa iei a fost de 2,8\%. Mai mult, finan area per elev/student e direct propor ională cu nivelul de studii. Astfel, în învă ământul universitar se cheltuie de 2,3 ori mai mult pe student decât se cheltuie cu un elev în învă ământul primar şi gimnazial şi de 1,8 ori mai mult decât în învă ământul liceal şi post-liceal. În acelaşi timp, rata de părăsire timpurie a şcolii ${ }^{6}$ este printre cele mai mari din UE, aproximativ 16,4\% în 2018 - prin compara ie media UE28 este $10,6 \%$.

Se poate argumenta că există un număr important de tineri care au finalizat cel mult învă ământul gimnazial şi că sunt predispuşi să fie în categoria NEET, având în vedere faptul că finalizarea studiilor gimnaziale reprezintă o condi ie obligatorie pentru ob inerea unei calificări. În mediul rural situa ia este şi mai problematică în contextul în care rata de părăsire timpurie a şcolii este 25,4\% (Eurostat, indicator [edat_lfse_30]). Nu în ultimul rând, în România sărăcia în rândul tinerilor cu vârste cuprinse între 15 şi 24 ani a scăzut pentru prima dată sub 40\% abia în 2018 (39\%), lucru care afectează participarea la educa ie şi ob inerea unui loc de muncă. Situa ia din viitor nu este promi ătoare, în contextul în care participarea la educa ie este influen ată negativ de sărăcie, iar procentul copiilor între 6 şi 10 ani afla i în risc de sărăcie sau excluziune socială a scăzut abia în ultimii doi ani sub 50\% (nivelul din 2018 era 41\%), în timp ce procentul celor cu vârste cuprinse între 11 şi 15 ani, afla i în risc de sărăcie sau excluziune, era, în anul 2018, de aproximativ $39 \%$ (Eurostat, indicator [ilc_peps01]).

Poten ialele probleme la ieşirea din sistemul educa ional pot fi ilustrate şi de testările interna ionale PISA. Acestea îşi propun evaluarea competen elor de citire, matematică şi ştiin e pentru elevii de 15 ani. Rezultatele elevilor din România sunt slabe, sub media OECD, iar discu iile cu privire la testările din 2012, 2015 şi 2018 s-au concentrat pe lipsa competen elor de bază, denumite în presă ,,analfabetism func ional”. Dintre elevii participan i la PISA, aproape $40 \%$ sunt sub nivelul $2^{7}$, adică pot în elege texte şi rezolva probleme de dificultate redusă (dublu fa ă de media UE28). Mai mult, impactul statutului socioeconomic al părin ilor ${ }^{8}$ este unul major: aproximativ $60 \%$ dintre elevii 
cu un statut socioeconomic scăzut nu au competen e de bază. Dacă împăr im elevii în grupuri în func ie de statutul socioeconomic al părin ilor, putem spune că lipsa competen elor de bază este de 3 ori mai probabilă în cazul elevilor din ultima quartilă, comparativ cu prima. În contextul discu iei despre tinerii NEET, lipsa competen elor de bază este foarte relevantă, aceasta fiind, cel mai probabil, un impediment important pentru integrarea pe pia a muncii, în special a grupurilor defavorizate.

Într-o analiză anterioară am arătat, folosind datele PISA, că factorii care influen ează scorurile ob inute la citire, matematică şi ştiin e variază semnificativ în func ie de ocupa ia părin ilor şi de stocul de capital cultural de inut în familie, iar dintre resursele şcolare, cel mai important factor este calitatea resurselor educa ionale din şcoală $\breve{a}^{9}$, care are totuşi un efect mai mic, comparativ cu factorii familiali ( oc, 2016, 2018). Inegalită ile nu sunt ilustrate numai de testările interna ionale, ci şi de testările na ionale, pe baza cărora se face repartizarea la liceu. De exemplu, la testările na ionale din clasa a VIII-a, în anul 2018 aproximativ 35\% dintre elevii din mediul rural au ob inut sub nota 5 , fa ă de numai $14 \%$ în mediul urban ${ }^{10}$. Nu în ultimul rând, participarea la educa ie a elevilor romi a fost şi rămâne o problemă constantă în România: doar 38\% dintre copiii romi de 4 şi 5 ani frecventează grădini a (fa ă de $87 \%$ total), $77 \%$ dintre tinerii romi cu vârste cuprinse între 18 şi 24 ani au părăsit timpuriu şcoala; $64 \%$ dintre tinerii romi sunt NEET, 29\% dintre elevii romi înva ă în continuare în clase segregate etnic (FRA, 2016). Percep iile func ionarilor din serviciile sociale, ilustrate de datele calitative colectate de ISE (2015, pp. 68-69), sunt că se lucrează cu dificultate cu persoanele de etnie romă. Aceştia atribuie cauzele eşecului şcolar şi de integrare ocupa ională mai degrabă indivizilor (etnicilor romi) şi mai pu in institu iilor educa ionale sau problemelor de pe pia a muncii. În general, sunt folosite simplificări stereotipale pentru a explica eşecul, putând fi resim ită şi o resemnare în discursurile func ionarilor intervieva i: ,,sunt refractari”, ,,sunt limita i”, ,,abandonează din cauza tradi iilor, a căsătoriilor timpurii şi a faptului că fac copii devreme”, ,,problema porneşte de la educa ia părin ilor, de la cei 7 ani de acasă". Pe de altă parte, tinerii romi NEET au relatat experien e care ilustrează dezavantaje structurale majore, cele mai importante fïind sărăcia şi excluziunea socială, iar în plan secund se poate discuta despre subaprecierea propriilor abilită i. Aşadar, institu iile educa ionale şi cu atât mai pu in institu iile care oferă asisten ă socială nu 
sunt considerate responsabile pentru facilitarea accesului şi participării la educa ie a elevilor.

În condi iile în care sistemul de învă ământ se confruntă cu aceste probleme, este explicabilă dificultatea tranzi iei din sistemul educa ional către pia a muncii pentru tinerii din România. Sistemul de învă ământ nu oferă şanse egale la educa ie elevilor din medii dezavantajate ${ }^{11}$, fiind mai probabil ca aceştia să părăsească timpuriu şcoala, să nu aibă competen e de bază sau să urmeze un liceu aflat în ultima quartilă din punctul de vedere al notelor, care oferă şanse mici de îmbunătă ire a nivelului competen elor. Practic, acest lucru sugerează incapacitatea sistemului de învă ământ de a contribui la procese de mobilitate socială ascendentă, fiind mai probabilă ,contribu ia” acestuia la reproducerea inter-genera ională a sărăciei.

Cu toate că lipsa educa iei este un impediment major în integrarea tinerilor afla i în situa ie de vulnerabilitate din România pe pia a muncii, acesta nu este singurul. Dragolea (2016) argumentează că, în contextul în care riscul de sărăcie s-a men inut constant în perioada post-criză, se poate vorbi despre un eşec al politicilor redistributive în România. Cheltuielile publice alocate pentru reducerea excluziunii sociale au fost constant scăzute în ultimii 10 $\operatorname{ani}^{12}$ (0,2\% din PIB în medie, comparativ cu 0,5 în UE28), iar riscul de sărăcie după efectuarea transferurilor sociale este printre cele mai ridicate din Europa, în special în rândul tinerilor ${ }^{13}$ (Dragolea, 2016, pp. 205-206). Mai mult, transferurile financiare directe nu sunt suficiente pentru oferirea unei protec ii sociale adecvate, iar transferurile non-financiare destinate protec iei sociale sunt de 10 ori mai mici comparativ cu UE 28 (ibid., pp. 206-212). Toate aceste informa ii sugerează un impact scăzut al cheltuielilor cu protec ia socială în oferirea de şanse de a ieşi din sărăcie grupurilor vulnerabile. În ultimă instan ă, pia a muncii oferă pu ine oportunită i reale, iar acolo unde există, sunt în general caracterizate prin salarii scăzute şi condi ionate de naveta zilnică. Cercetarea calitativă realizată de Preoteasa (2015) este sugestivă din acest punct de vedere, autoarea argumentând faptul că alternativele la ocuparea formală în comunitatea rurală studiată sunt: munca la negru, pensionarea anticipată, migra ia sau agricultura de subzisten ă. Dintre factorii identifica i de Preoteasa (2015), cei mai importan i sunt de natură contextuală: lipsa infrastructurii de transport; lipsa ofertei de muncă la nivelul localită ii; absen a serviciilor publice de îngrijire a copiilor şi 
a persoanelor dependente (adul i sau vârstnici). Nivelul salariului, care este unul scăzut, în special pentru persoanele necalificate sau slab calificate, cu un nivel de şcolaritate redus, poate fi de asemenea o barieră importantă, mai ales dacă este condi ionat de navetă şi lucru în schimburi ${ }^{14}$. Nu în ultimul rând, în raportul ISE (2015, p. 37) sunt recunoscute constrângerile întâmpinate de tinerii NEET, generate de lipsa locurilor de muncă, calitatea şi remunerarea acestora.

\section{Strategii privind reducerea inegalită ilor}

Cel mai important document strategic în care regăsim ca propunere explicită reducerea inegalită ilor este Pilonul European al Drepturilor Sociale, care îşi propune asigurarea echită ii şi dreptă ii sociale în Uniunea Europeană ${ }^{15}$. Acesta reuneşte 20 de principii care vizează domenii de politici publice care variază de la excluziune socială şi discriminare, până la solidaritate genera ională şi protec ia drepturilor copilului. Trei direc ii de ac iune sunt considerate fundamentale: şanse egale şi acces la pia a for ei de muncă; condi ii de muncă echitabile; protec ie socială şi incluziune socială.

Cea mai recentă evaluare, realizată la nivelul datelor statistice din anul $2016^{16}$, arată faptul că situa ia României este una critică la nivelul indicatorilor din cadrul celor trei direc ii de analiză. Astfel, România înregistrează valori critice la indicatori precum: persoanele care părăsesc timpuriu sistemul formal de educa ie şi formare profesională; decalajul de ocupare dintre femei şi bărba i; numărul persoanelor aflate în risc de sărăcie şi excluziune socială şi ponderea tinerilor care nu sunt angaja i şi nici nu sunt cuprinşi în sistemul educa ional sau de formare profesională. În privin a evaluării progresului strategiilor şi politicilor publice care vizează Pilonul European al Drepturilor Sociale în domeniul protec iei sociale şi incluziunii, România înregistrează valori scăzute la indicatori precum: impactul transferurilor sociale asupra reducerii sărăciei, nevoii neîndeplinite de îngrijire medicală şi nivelul competen elor digitale ale indivizilor, precum şi o situa ie slabă, dar în curs de ameliorare, a indicatorului privind participarea în învă ământul preşcolar a copiilor cu vârste mai mici de 3 ani. 
Potrivit unei analize elaborate de Fondul Monetar Interna ional (Chen et al., 2018), inegalitatea economică între tineri şi vârstnici a crescut semnificativ după criza economică din 2008. Tinerii au o probabilitate mai ridicată de a se afla în situa ia de risc de sărăcie sau excluziune socială decât vârstnicii, iar în unele ări (inclusiv România), munca nu reprezintă în mod obligatoriu o garan ie pentru ieşirea din sărăcie, în contextul prevalen ei sărăciei în muncă (17,4\% în 2017, conform Eurostat, indicator [ilc_iw01]) şi al ocupării parttime involuntare (mai mult de jumătate din contractele part-time înregistrate în România intră în categoria „ocuparea part-time involuntară” conform Eurostat, indicator [lfsa_eppgai]). Chiar FMI recunoaşte faptul că politicile de consolidare fiscală, alături de evolu ia pie ei muncii şi de designul institu iilor de protec ie socială, au contribuit la exacerbarea inegalită ilor existente anterior crizei economice, la şomajul în rândul tinerilor şi la trendul către locurile de muncă mai pu in stabile. Mai mult, inclusiv tinerii care au contracte de muncă ce le oferă venituri suficiente pentru asigurarea unui trai decent (Guga et al., 2018) sunt vulnerabili, în eventualitatea în care îşi pierd locul de muncă, întrucât de in numai 5\% din totalul avu iei din Europa şi fie au credite ipotecare, fie plătesc chirie, în mai mare măsură decât alte categorii de vârstă (Chen et al., 2018). De asemenea, şomajul în rândul tinerilor are un efect important asupra participării viitoare pe pia a muncii. Este mai probabil ca tinerii care au experimentat şomajul să aibă locuri de muncă precare, să aibă mai multe perioade de şomaj, să aibă o stare de sănătate mai proastă şi o bunăstare generală scăzută (O'Reilly et al., 2015). Mai mult, există în Europa un proces de „moştenire” a dezavantajelor, tinerii care au avut părin i şomeri având o probabilitate ridicată să experimenteze şomajul.

Scopul general al unei politici în domeniul tineretului este de a facilita depăşirea provocărilor şi obstacolelor de către tineri, în tranzi ia de la copilărie la via a adultă (Siurala, 2006). Din acest punct de vedere, situa ia din România este ilustrată în ultimul raport elaborat în cadrul proiectului EXCEPT $^{17}$, proiect de cercetare ce şi-a propus să analizeze situa ia tinerilor pe pia a muncii şi care se află în risc de excluziune socială în Uniunea Europeană şi Ucraina (Pantea, 2018). Potrivit raportului, în cazul României, problema tinerilor nu e considerată foarte importantă, dacă este să ne uităm la agenda de politici publice sau chiar la agenda de cercetare. Acest lucru este explicat în principal prin faptul că un procent semnificativ de tineri migrează în Europa de Vest, dar şi prin faptul că absenteismul electoral nu îi 
face un grup foarte relevant pentru elaborarea de politici, mai ales că, în contextul disparită ilor regionale, tinerii reprezintă un grup eterogen.

Conform aceluiaşi raport, institu iile din România nu înregistrează date privind programele destinate integrării pe pia a muncii a tinerilor, iar procentul din PIB alocat politicilor active de (re)integrare pe pia a muncii este insignifiant (ibid.). Una dintre cele mai importante ini iative menite să sprijine tinerii vulnerabili este INTESPO - Înregistrarea Tinerilor în Eviden ele Serviciului Public de Ocupare ${ }^{18}$, scopul central fiind acela de a creşte numărul de tineri NEET înregistra i pentru a sprijini integrarea acestora în programe de formare şi pe pia a muncii. Activită ile au fost mai degrabă axate pe o componentă administrativă şi nu iau în calcul problemele structurale cu impact asupra şomajului în rândul tinerilor, precum: lipsa locurilor de muncă de calitate şi bine plătite, costurile ascunse ale continuării educa iei, calitatea redusă a educa iei profesionale, raportul problematic dintre salarii şi costul vie ii, formele atipice de ocupare, în special ocuparea precară, tot mai răspândite (Pantea, 2018).

Alte programe implementate au vizat dezvoltarea sistemului de ucenicie din România. Ucenicia este considerată ca o solu ie pentru facilitarea tranzi iei tinerilor de la şcoală la pia a muncii, oferind formare profesională ini ială şi continuă de calitate şi asigurând un loc de muncă ce furnizează securitate socială pentru tineri. Însă, potrivit Raportului Proiectului Pilot IER: Evaluarea sistemului de Ucenicie din România, elaborat de Ministerul Muncii, Familiei, Protec iei Sociale şi Persoanelor Vârstnice (2015), au fost încheiate un număr redus de contracte. Evaluarea realizată de Pantea (2018) sugerează că programul nu reuşeşte să aibă un impact asupra principalelor cauze ale şomajului şi excluziunii sociale în rândul tinerilor. Interven iile sunt mult prea centrate pe companii, iar riscul utilizării ucenicilor pe post de angaja i nu este luat în considerare. Nu în ultimul rând, nu există dovezi care să sugereze că stagiile de ucenicie au întrerupt seria ,locurilor de muncă pe termen scurt" şi că, în final, calificările au fost utilizate cu succes de tineri pentru a găsi locuri de muncă.

Alte politici sociale care sunt în strânsă legătură cu incluziunea socială sunt cele legate de locuire sau de sprijinire a ocupării grupurilor vulnerabile. Programe precum „Prima chirie" ${ }^{19}$ au ca obiectiv sprijinirea persoanelor 
care se deplasează pentru ob inerea unui loc de muncă la o distan ă mai mare de $50 \mathrm{~km}$, pe o perioadă de maximum 36 de luni. Programul nu a func ionat însă, numărul de beneficiari a fost redus, iar principalele cauze ale excluziunii sociale sau şomajului în rândul tinerilor nu au fost luate în considerare. Mai mult, în implementarea programului nu s-a inut cont de disponibilitatea locurilor de muncă în proximitatea domiciliului (ibid.).

Un alt program este „Promovarea participării pe pia a muncii a tinerilor cu risc de marginalizare socială" ${ }^{20}$, care func ionează pe principiul subven ionării angajatorilor pentru fiecare persoană angajată, cu vârste cuprinse între 16-26 ani, care se află în diverse situa ii de marginalizare. Măsura a sprijinit integrarea pe pia a muncii a 50\% din numărul total de tineri afla i în grupul intă, însă evaluarea sugerează că este problematic din mai multe puncte de vedere: grupul intă este foarte eterogen, calitatea ocupării este scăzută (măsurată inclusiv prin măsurile de sprijin reduse pentru ca angajatorii şi ceilal i angaja i să fie pregăti i pentru a nu discrimina beneficiarii, pentru a în elege problemele cu care aceştia se confruntă) (ibid.).

Singurul exemplu de succes prezentat de Pantea (2018) este legat de oferirea de educa ie profesională tinerilor din sistemul secundar de învă ământ, prin parteneriat între sistemul public de educa ie, o companie privată şi elevi. Acest tip de interven ie a fost însă realizată la nivel local, numărul de beneficiari fiind scăzut. Cu toate acestea, pregătirea a fost considerată de calitate, iar tinerilor le-au fost oferite locuri de muncă în companie la finalizarea studiilor. Problema fundamentală a acestor programe care func ionează la scară mică este că, în condi iile implementării la o scară mai largă, angajatorii pot deveni foarte selectivi cu persoanele care finalizează învă ământul.

\section{Concluzii}

În această lucrare mi-am propus să analizez situa ia tinerilor vulnerabili din România într-un context mai larg. Accentul a fost pus pe tinerii NEET şi pe cei predispuşi să se afle în risc de excluziune socială. În prima parte am descris principalele tipuri de inegalită i sociale la care sunt expuşi tinerii din România. Tinerii reprezintă o categorie vulnerabilă, mai expusă riscului 
de sărăcie sau excluziune socială şi care este afectată de schimbările pie ei muncii şi de apari ia ocupa iilor atipice, inclusiv cele specifice capitalismului de tip platformă (companii care oferă solu ii hardware şi software astfel încât indivizi ter i să îşi desfăşoare activită i economice - Uber, Aribnb etc. $)^{21}$. În a doua parte am analizat care sunt principalele caracteristici ale tinerilor NEET din România în raport cu media UE28. Tinerii NEET locuiesc mai degrabă în mediu rural, oraşe mici sau suburbii, decât în urban; sunt distribui i uniform din punctul de vedere al nivelului de şcolaritate; sunt mai degrabă inactivi care nu îşi caută sau nu sunt disponibili pentru a munci, decât şomeri care au căutat activ un loc de muncă în ultimele 4 săptămâni; jumătate dintre tinerii NEET ar dori să muncească, indiferent dacă ei caută sau nu un loc de muncă, lucru care infirmă stereotipurile conform cărora decizia de a munci sau nu ine de o alegere individuală; diferen ele de gen sunt importante, numărul tinerelor NEET fiind mai mare, comparativ cu cel al bărba ilor şi sunt, mai degrabă, inactive şi, mai degrabă, indisponibile pentru a munci, comparativ cu bărba ii.

Am argumentat, de asemenea, că problema tinerilor vulnerabili trebuie în eleasă în raport cu problemele din învă ământ, dar şi cu cele de pe pia a muncii. Printre motivele cele mai importante pentru care tinerii ajung să fie vulnerabili se numără şi rezultatele sistemului de învă ământ românesc precum: abandon şcolar timpuriu ridicat; lipsa competen elor de bază la ieşirea din sistem; inegalită i educa ionale, în defavoarea celor cu statut socio-economic al familiei scăzut, fenomen ce duce la reproducerea intergenera ională a sărăciei. De asemenea, politicile sociale sunt ineficiente în reducerea sărăciei, iar structura pie ei muncii, disparită ile geografice şi diviziunea rural-urban reprezintă deseori un impediment în integrarea tinerilor, mai ales în contextul în care România este ara cu o pondere mare a persoanelor care deşi muncesc se află sub pragul sărăciei, situa ie cauzată în principal de numărul mare de persoane ocupate în munci agricole de subzisten ă realizate în propria gospodărie.

Analiza programelor în domeniul tineretului, cu accent pe cele care îşi propun incluziunea socială şi reducerea şomajului, în contextul austerită ii de după criza economică globală din 2008, ilustrează că impactul acestora este mai degrabă limitat (a se vedea şi Strat et al., 2018). Până în prezent, cele mai multe măsuri implementate în România au avut un impact scăzut asupra 
incluziunii sociale a grupurilor vulnerabile. $\mathrm{Cu}$ alte cuvinte, politicile şi programele implementate şi cele aflate în implementare nu reuşesc să atenueze problemele structurale care generează vulnerabilitate în rândul tinerilor. Luarea în considerare a particularită ilor grupurilor vulnerabile şi îmbunătă irea capacită ii administrative a serviciilor de ocupare pentru înregistrarea tinerilor afla i în căutarea unui loc de muncă, reprezintă condi ii importante pentru politicile ce îşi propun sprijinirea tinerilor. De asemenea, procesul de evaluare a impactului politicilor existente trebuie îmbunătă it, în condi iile în care evaluarea administrativă este preferată deseori studiilor de impact.

\section{Mul umiri}

Această lucrare a primit sprjin financiar din partea Programului Opera ional Capital Uman 2014-2020, co-finan at prin Fondul Social European, proiect POCU/ 380/6/13/124708 nr. 37141/23.05.2019, cu titlul, ,Cercetător-antreprenor pe pia a muncii în domeniile de specializare inteligentă (CERT-ANTREP)", coordonat de către Şcoala Na ională de Studii Politice şi Administrative. Doresc, de asemenea, să aduc mul umiri Irinei Lonean, recenzen ilor şi editorilor Revistei de Pedagogie pentru comentariile pertinente pe primele versiuni ale acestui articol.

\section{NOTE}

1 GINI măsoară modalitatea în care distribu ia veniturilor dintr-o ară se abate de la o distribu ie egală (unde zero înseamnă egalitate perfectă, iar 100 inegalitate perfectă).

2 S80/S20 reprezintă raportul dintre cei mai boga i $20 \%$ şi cei mai săraci $20 \%$ din punctul de vedere al veniturilor. $\mathrm{Cu}$ cât raportul e mai mare cu atât inegalitatea dintre cele două grupuri e mai mare.

3 Tineri care nu sunt nici angaja i, nici nu îşi continuă educa ia sau formarea.

4 Detalii aici: https://ec.europa.eu/social/main.jsp?catId=1079\&langId=en

5 Detalii aici: https://ec.europa.eu/social/main.jsp?catId=1176

6 Procentul popula iei cu vârste între 18-24 care au cel mult şcoală gimnazială şi nu se mai află în sistemul de educa ie sau formare.

7 „Nivelul 2 este considerat nivelul de bază necesar a fi atins de către un tânăr de 15 ani până la finalizarea învă ământului obligatoriu, pentru a putea func iona eficient în societatea cunoaşterii." (https://www.edu.ro/rezultatele-elevilorrom\%C3\%A2ni-la-testarea-oecd-pisa-2015). 
8 OECD a construit un index al statusului economic, social şi cultural care ia în considerare educa ia şi ocupa ia părin ilor, dar şi bunurile materiale, culturale şi resursele educa ionale de inute în familie (OECD, 2016).

9 Aprecierea directorilor cu privire la calitatea materialelor de instruc ie, echipamente de laborator, computere, softuri şi internet, materiale din bibliotecă. Detalii aici: https://www.edu.ro/sites/default/files/2017-06-30\%20Dosar\% 20EN\%202017\%20v3.pdf

11 Criteriile pentru stabilirea mediilor dezavantajate sunt multiple, iar unii indivizi pot experimenta mai multe în acelaşi timp. De exemplu, probabilitatea ca o femeie romă, dintr-o comunitate săracă, ai cărei părin i au un nivel de şcolaritate scăzut, un statut precar pe pia a muncii, care locuieşte în mediul rural şi are lipsuri materiale majore va întâmpina dezavantaje multiple în participarea la educa ie, inclusiv generate de efecte comune ale acestor factori.

12 Eurostat, indicator [spr_exp_gdp].

13 Înainte de transferuri sociale, riscul de sărăcie era în anul 2015 29,3\%, iar după transferuri sociale $25,4 \%$ (în UE28 era $25,9 \%$ înainte de transferuri sociale, respectiv 17,3\% după transferuri) (Eurostat (ilc_li10), (ilc_li02)).

14 De exemplu, o familie formată din doi adul i şi doi copii care au veniturile totale formate din două salarii minime şi două aloca ii pentru copii nu au reuşit să atingă în ultimii 27 de ani nivelul calculat al coşului minim decent şi nici nivelul coşului minim de subzisten ă (Zamfir et al., 2017).

15 Detalii aici: https://ec.europa.eu/commission/priorities/deeper-and-fairereconomic-and-monetary-union/european-pillar-social-rights/european-pillarsocial-rights-20-principles_ro\#

16 Vezi Social Score Board 2018, disponibil la adresa: http://europa.eu/rapid/ attachment/IP-18-1341/en/Factsheet\%20-\%20Social\%20Scoreboard\%20$\% 202018 \% 20$ Country\%20Reports.pdf

17 Detalii aici: http://www.except-project.eu/about-the-project/

18 Detalii aici: http://www.mmanpis.ro/intespo-inregistrarea-tinerilor-in-evidenteleserviciului-public-de-ocupare-pocu13523113589/

19 Detalii aici: http://gov.ro/ro/guvernul/sedinte-guvern/norme-pentru-aplicareaprogramului-prima-chirie-destinat-stimularii-mobilitatii-fortei-de-munca

20 Detalii aici: http://www.ajofmiasi.ro/continut/servicii-pentru-angajatori\#ancora6

21 Detalii aici: https://www.eurofound.europa.eu/data/platform-economy/records/ platform-capitalism

\section{Referin e}

- Briciu, C. (2016). Politici sociale de locuire. Calitatea vie ii, 27(1), 42-62.

- Brown, P., \& Lauder, H. (2010). Economic globalisation, skill formation and the consequences for higher education. In M. Apple, S. Ball \& L. A. Gandin 
(Eds.), The Routledge International Handbook of the Sociology of Education. Routledge.

- Chen, T., Hallaert, J.-J., Pitt, A., Qu, H., Queyranne, M., Rhee, A., Shabunina, A., Vandenbussche, J., \& Yackovlev, I. (2018). Inequality and Poverty across Generations in the European Union. International Monetary Fund.

- Crenshaw, K. (1991). Mapping the Margins: Intersectionality, Identity Politics, and Violence Against Women of Color. Stanford Law Review, 43(6), 12411299. https://doi.org/10.2307/1229039

- Dragolea, A. (2008). Preferin e şi mecanisme pe pia a muncii-o abordare de gen sau cum ,aleg” femeile performan e profesionale mai scăzute şi bani mai pu ini. În O. Bălu ă (Ed.), Gen şi interese politice. Teorii şi practici. Tritonic.

- Dragolea, A. (2016). Statul bunăstării după criza economică. Tritonic.

- Domnişoru, C. (2014). The largest drop in income inequality in the European Union during the Great Recession: Romania's puzzling case. ILO.

- Eurofound. (2012). NEETs - Young people not in employment, education or training: Characteristics, costs and policy responses in Europe. Publications Office of the European Union.

- Eurofound. (2013). Third European Quality of Life Survey - Quality of life in Europe: Social inequalities. Publications Office of the European Union.

- Eurofound. (2016). Exploring the diversity of NEETs. Publications Office of the European Union.

- European Commission. (2017, 2018, 2019). Education and training monitor Romania. Publications Office of the European Union.

- European Commission. (2018). 2018 Report on equality between women and men in the EU. Publications Office of the European Union.

- Ferrera, M. (2010). The South European Countries. In F. G. Castles, S. Leibfried, J. Lewis, H. Obinger \& C. Pierson (Eds.), The Oxford Handbook of the Welfare State. OUP Oxford.

- Florian, B., \& oc, S. (2018). What Happens to Policies When Assuming Institutions? A Short Story About Romania's Never-Ending Educational Reform. European Education, 50(4), 320-335. https://doi.org/10.1080/10564934.2017.1344862

- Hatos, A. (2006). Sociologia educa iei. Polirom.

- Guga, Ş., Mihăilescu, A., \& Spătari, M. (2018). Coşul minim de consum lunar pentru un trai decent pentru popula ia României. Studiu Syndex.

- ISE. (2015). Aspecte privind incluziunea socială a tinerilor afla $i$ în afara sistemelor de educa ie, formare şi ocupare profesională (NEET). http://www.ise.ro/wp-content/uploads/2016/12/Raport-cercetare-NEET_final_ 2016.pdf.

- Ministerul Muncii, Familiei, Protec iei Sociale şi Persoanelor Vârstnice. (2015). Raport Proiect Pilot EIR: Evaluarea Sistemului de Ucenicie din România. 
http://sgg.gov.ro/docs/File/UPP/doc/analiza_impact/Analiza\%20privind\% 20sistemul\%20de\%20ucenicie\%20in\%20Romania.pdf

- Monitorul social. (2018). Contracte de muncă: întreprinderi de stat vs întreprinderi private. Funda ia Friedrich Eberth Stiftung.

https://monitorsocial.ro/data/contracte-de-munca-intreprinderi-de-stat-vsintreprinderi-private/

https://monitorsocial.ro/indicator/contracte-de-munca-intreprinderi-de-stat-vsintreprinderi-private/?fbclid=IwAR1TnT_3Omv_cz1eahBtRQIyVG4VkL fo0YpmqZmZxIhqNzgSB_0IQZKYNOU

- OECD. (2016). PISA 2015 Results in Focus. OECD Publishing.

- O’Reilly, J., Eichhorst, W., Gabos, A., Hadjivassiliou, K., Kurakova, L., Lain, D., Lesckhe, J., McGuinness, S., Nazio, T., Ortlieb, R., Russell, H., \& Villa, P. (2015). Five Characteristics of Youth Unemployment in Europe: Flexibility, Education, Migration, Family Legacies, and EU Policy. SAGE Open, 5(1), 1-19. https://doi.org/10.1177/2158244015574962

- Pantea, M. C. (2018) Youth employment policies in Romania. EXCEPT Working Papers, WP No. 45, Tallinn University.

http://www.except-project.eu/working-papers/

- Plăeşu, A. (coord.) (2015). Discriminarea-factor de risc în incluziunea socială a tinerilor NEET. Pro Universitaria.

- Precupe u, I., \& Pop, C. E. (2017). Pentru o abordare socială în domeniul sănătă ii. Factorii structurali ai determinării stării de sănătate. Calitatea vie ii, 28(3), 219-242.

- Preoteasa, A-M. (2015). Munca precară, solu ie pentru popula ia vulnerabilă din mediul rural. Rezultate dintr-o cercetare calitativă. Calitatea vie ii, 26(1), 36-59.

- Ra , C. (2010). Incluziune adversă. Presta ii sociale şi persisten a sărăciei în rândul romilor din România. In S. Toma \& L. Foszto (Eds.), Spectrum: Cercetări sociale despre romi. Editura Institutului pentru Studierea Problemelor Minorită ilor Na ionale.

- Siurala, L. (2006). A European framework for youth policy. Directorate of Youth and Sport Council of Europe Publishing.

- Strat, V. A., Trofin, L., \& Lonean, I. (2018). A theory based evaluation on possible measures which increase young NEETs employability. Proceedings of the International Conference on Business Excellence, 12(1), 931-941. https://doi.org/10.2478/picbe-2018-0083

- Sandu, D. (2010). Lumile sociale ale migra iei româneşti în străinătate. Polirom.

- oc, S. (2016). Familie, şcoală şi succes şcolar în învă ământul liceal românesc. Calitatea vie ii, 27(3), 189-215.

- oc, S. (2018). Clasă şi educa ie. Inegalitate şi reproducere socială în învă ământul românesc. Pro Universitaria. 
- Zamfir, C. (2012). Ce fel de tranzi ie vrem? Analiza critică a tranzi iei II, Raportul social al ICCV nr. 5.

http://old.iccv.ro/sites/default/files/Raport\%20ICCV\%205-2012.pdf

- Zamfir, C. (Eds.). (2017). Raport social al ICCV 2017. Starea socială a României.

Calitatea vie ii: situa ia actuală şi perspective pentru 2038.

http://www.csnmeridian.ro/files/docs/Raport\%20social\%20Academia\%20

Romana\%20-\%20ICCV\%202017.pdf

The online version of this article can be found at: http://revped.ise.ro/category/2020-en/

\section{(oc) EY-NG-BA}

This work is licensed under the Creative Commons Attribution-NonCommercial-ShareAlike 4.0 International License.

To view a copy of this license, visit http://creativecommons.org/licenses/by-nc-sa/4.0/ or send a letter to Creative Commons, PO Box 1866, Mountain View, CA 94042, USA.
Versiunea online a acestui articol poate fi găsită la: http://revped.ise.ro/category/2020-ro/

\section{(c) EY-NC-SA}

Această lucrare este licen iată sub Creative Commons Attribution-NonCommercial-ShareAlike 4.0 International License.

Pentru a vedea o copie a acestei licen e, vizita $i$ http://creativecommons.org/licenses/by-nc-sa/4.0/ sau trimite i o scrisoare către Creative Commons, PO Box 1866, Mountain View, CA 94042, SUA. 



\title{
LOW QUALITY OF THE EDUCATIONAL PROCESS - MAIN CAUSE OF THE EARLY SCHOOL LEAVING
}

\author{
Technical University of Civil Engineering, \\ National Center for Policy and Evaluation in Education, \\ Education Research Unit, \\ Bucharest, Romania \\ adelataranu@gmail.com
}

Adela Mihaela ăranu*

\begin{abstract}
The association of three concepts - quality, equity, inclusion - represents the transversal axis of international and European educational policy documents nowadays, hence being an important aim for all education systems. According to the UNESCO strategic documents on education for the period up to 2030 and to the development objectives for this millennium, the creation of inclusive educational systems stands as the surest path to social inclusion. Inclusion is an aspect consistent with value and with the principle of equity, aimed at ensuring the right of all children to develop and reach their full potential. The European Commission defines equity as the extent to which individuals can benefit from and access educational opportunities, educational interventions and outcomes, along with those of professional education and training.

At an international level, the early school leaving indicator assesses the extent to which a given system manages to fight inequalities in terms of exclusion. According to the Eurostat 2019 data on Romania, at a level of $16.4 \%$ in 2018 , the early school leaving and training rate (for individuals aged 18 to 24) remains one of the highest rates in the EU. The percentage is significantly higher compared to the EU average and to the national target for 2020. The study argues that in spite of the policies for
\end{abstract}

* Associate profesor PhD, Technical University of Civil Engineering, Teacher Training Department, Bucharest, Romania.

Researcher, National Center for Policy and Evaluation in Education (NCPEE),

Education Research Unit, Bucharest, Romania. 
improving the quality of education over the past decade, most of the measures are focused on approaching the social barriers regarding the access to education, and less on increasing the quality of the education provided in schools (education as a process).

Keywords: early school leaving, educational policies, equity, inclusive education, quality education.

\section{Rezumat}

Asocierea a trei concepte - calitate, echitate, incluziune - reprezintă acum axa transversală a documentelor de politici educa ionale interna ionale şi europene, deci şi o intă importantă pentru toate sistemele de învă ământ. Potrivit documentelor strategice ale UNESCO referitoare la educa ie în perspectiva anului 2030 şi la obiectivele de dezvoltare pentru mileniul în curs, calea cea mai sigură pentru incluziunea socială o reprezintă crearea sistemelor educa ionale incluzive. Incluziunea reprezintă un aspect consecvent valorii şi principiului echită ii, menit să asigure dreptul tuturor copiilor de a se dezvolta şi de a-şi atinge întregul poten ial. Comisia Europeană defineşte echitatea drept gradul în care persoanele pot valorifica accesul şi oportunită ile educa ionale, interven iile şi rezultatele educa iei, respectiv ale formării profesionale.

La nivel interna ional, indicatorul ,early school leaving” înregistrează măsura în care un sistem reuşeşte să combată inechită ile în termeni de excluziune. Conform datelor Eurostat 2019 pentru România, la un nivel de 16,4\% în 2018, rata părăsirii timpurii a şcolii şi formării (de către persoanele între 18 şi 24 de ani) rămâne una dintre cele mai crescute din UE. Procentul este semnificativ ridicat comparativ cu media UE şi fa ă de inta na ională pentru 2020. Studiul sus ine că, în ciuda politicilor de îmbunătă ire a calită ii educa iei din ultimul deceniu, majoritatea măsurilor sunt axate pe abordarea barierelor sociale în calea participării şcolare şi mai pu in pe creşterea calită ii educa iei oferite în şcoli (calitatea de proces).

Cuvinte-cheie: calitatea educa iei, echitate, educa ie incluzivă, părăsirea timpurie a şcolii, politici educa ionale. 


\section{Three concepts, multiple challenges}

Quality, equity and inclusion are the three concepts aimed at fundamentally changing educational perspectives and practices. On the quality - quantity axis, our aim is to point out the dynamics of such concepts as school participation and inclusion. As it is characteristic to systems, satellite concepts gravitate at the intersection between values and actions, serving an important role in the assessment of the distance between declarative/ ideational and actuality/ practicality. Such a concept is the one of early school leaving, the key through which we will then look at the specific educational policies at the European level and at the level of the Romanian educational system as well. This analysis has the aim to underline, as much as possible, the evolutions, the snapshot realities and the effects that these concepts will have as they are identified in the field of literature. We think that a reflexive approach will be interesting for researchers, evaluation programme staff and teachers, which can observe the cleavages between practice and the theoretical conceptualisation and, as a result, they could adopt a creative approach on their practice.

\subsection{Quality education, between unification and conceptual problematisation}

The concept of quality education is a constant concern in terms of the education-focused type of discourse at international level, with a recent comeback through the increasingly sustained attempts at its operationalisation. Organisations such as UNESCO, the World Bank, OECD or the institutions of the European Union emphasise that high-quality education is a crucial matter in post-2015 educational agendas, correlated with the social and economic development objectives of the states. On the other hand, there is not any consensus on the conceptualisation of quality, as shown by a document of $\operatorname{UNESCO}(2005$, p. 1): 'There is no one definition, list of criteria, a definitive curriculum, or list of topics for a quality education. Quality education is a dynamic concept that changes and evolves with time and changes in the social, economic and environmental contexts of place'. Beyond the international discourse, with the movement for ensuring the quality of education, at the level of national systems the 
main challenge is the need of increasing the quality of education in terms of how to ensure high-quality education in a cost-effective manner.

A series of articles and summary reports on literature (Laurie et al., 2016) refer to several dominant models: (1) the economic model of education, based on the theory of human capital, refers to quantifiable inputs and outputs (measurable quantitative results); (2) the humanistic model, based on the theories of human development, regards education as a process at the centre of which are the pupils and students and it refers to broader personal and social objectives; (3) the model of contextualised learning/ education, based on the constructivist paradigm, proposes the integration of the relevant knowledge from the local level onto academic learning as a solution for ensuring the sustainability of the programmes.

Some authors recommend several unifying perspectives on quality, such as the framework for quality education designed by Nickel and Lowe (2010, p. 599) structured on seven dimensions of quality in education: effectiveness (the extent to which the declared educational objectives are accomplished), efficiency (the economic grounds of quality), equity (ensuring access and participation in education for all individuals), responsiveness (responding to the needs of every pupil taking their uniqueness into consideration), relevance (the utility of education for pupils both in the short and long term), reflexivity (the ability to adapt to change and uncertainty), and sustainability (a focus on behaviour change and the increase of responsibility at individual, local and global levels).

The mere reading of these dimensions shows that the sphere which the concept of quality aims to encompass is impossible to be described so that its complex reality can be analysed and improved. Hence, educational policies have encouraged educational systems to assume more liberty/ decentralisation in terms of choosing management models and assuming responsibility toward the actors involved. At the same time, stances of teachers and researchers were developed, according to which liberty and professional responsibility must be protected from the external assessment of the educational processes as a product of quality assurance procedures (Doherty, 2008). Conversely, an increasingly noticeable suggestion regards an orientation toward reflection on the practices/ the analysis of the micro- 
processes of teaching and learning and of quality work (Elken \& Stensaker, 2018). Moreover, a group of theorists and practitioners in the field of education influenced by the philosophy of Deleuze (Dahlberg, 2016; Moss, 2016) support the search for alternatives to quality, which they regard as counterproductive in relation to the social and educational objectives referring to diversity, participation, inclusion and innovation. The beyond quality movement advocates that the desire for quality, the language of quality, and the methods for quality continue to dominate throughout policy documents, academic studies, and the discourses of practitioners, oftentimes void of content and thus lacking the possibility of problematisation, which may entail great disservice for education (Moss, 2016, p. 132).

\subsection{Educational equity, beyond equality}

The concept of equity is very often invoked in relation to that of quality, even as a dimension of the quality of education, as mentioned above. Its discursive sphere comprises concepts such as social justice, solidarity, responsibility, tolerance, individual autonomy, exclusion / marginalisation. Whereas equity gradually became a common ground, there are heavily ideological discourses of deficit and drawbacks running in the background that come to insidiously stereotype the representations of teachers, the curricula and pedagogical practices (Webster \& Ryan, 2018).

The promotion of equity in education was introduced by the United Nations through key documents and the 2015 Incheon Declaration which reaffirmed the importance of equity for a renewed education agenda (UNESCO, 2015). The OECD also has a history of over 50 years advocating for the concepts of equality and equity, oriented in four directions: equity of access or equality of opportunity, equity in terms of learning environment or equality of means, equity in production or equality of achievement (of results), and equity in using the results of education (Levin, 2003). Also, the EU designed relevant documents on the matter of equity at the level of its member states, especially after the year 2000. In one of them, the EU defines equitable education systems as those that make sure that the results of education and training are independent from the socio-economic environment or from other factors leading to educational disadvantages, and that the educational interventions 
reflect the individuals' specific learning needs (CEC, 2006, p. 2).

As in the case of quality, there is no consensus on the conceptualisation of equity either. An extremely large amount of literature was written on the topic of equity in education, indicating, if we were to greatly simplify it, on the one hand the acknowledgement of the fact that there are groups struggling with significant obstacles in education (especially referring to women, ethnic minorities, disabled persons and socio-economically disadvantaged groups) and, on the other hand, expressing the intention of promoting education for all. Educational equity implies the adjustment of educational opportunities (including adaptation, varied resources and media) in order to respond to the needs of all and each, which are not the same/ equal. In contrast, equalityif it refers to equal chances, the equality of results or the equality of opportunity - implies the uniform distribution of resources and services, regardless of needs, hence regardless of individual and social circumstances (Levin, 2003, p. 9).

It is a known fact that school is not a neutral space and that individual data do not become barriers or opportunities in isolation, but only in interaction with others in the common space (of school), hence the idea that educational inequity is related to the inequality in the capacity of various groups to influence the structure of the curriculum, the essence of formal education (Webster \& Ryan, 2018, p. 127). The effectiveness of policies in the field depends on the knowledge of the phenomenon; hence, one of the challenges is the necessity to make inequity visible. The definitions of educational inequality usually operate with three criteria, as noted by the authors of a Report carried out by the USA on the matter of educational equity (Edley et al., 2019, p. 23): the existence of significant disparities among groups in matters of graduation or access to educational resources, reflected in educational results; the existence of a weak correlation between resources and pupils' needs; the inadequacy of the efforts for reducing educational segregation or the structural disadvantages of a group of pupils. The report supports the introduction of certain indicators for equity that would offer decision makers and the concerned parties the occasion '...to make their own judgments as to the importance of an observed disparity and what can be done to reduce it, considering other calls on political will and resources' (Edley et al., 2019, p. 23). 


\subsection{Inclusion and the challenge of diversity in education}

Inclusion represents an aspect consistent with value and the principle of equity and it refers to the ability to ensure the right of all children to develop and reach their full potential (UN, Convention on the Rights of the Child, 1990). Even those who deconstruct concepts such as quality and equity in education agree that inclusion is a concept of maximum relevance for education and that inclusive education proposes the most viable actionable solutions possible (Jones et al., 2016).

The effects related to discrimination and segregation represent a constant concern of the UN in matters of human rights, and the moment of the World Declaration on Education for All (Jomtien, 1990) and the one of the Salamanca Statement (1994) are regarded as benchmarks in the acknowledgement at a global level of the fact that inclusive education is 'an ongoing process aimed at offering quality education for all while respecting diversity and the different needs and abilities, characteristics and learning expectations of the students and communities, eliminating all forms of discrimination' (UNESCO, 2008, p. 3).

Inclusion is also a concept highly reliant on values, hence 'the current debate is no longer about what inclusion is and why it is needed; the key question is how it is to be achieved' (European Agency for Special Needs and Inclusive Education, 2014, p. 5). The literature (European Agency for Special Needs and Inclusive Education, 2018) and metastudies (Göransson \& Nilholm, 2014) on the empirical evidence observe the challenges of the implementation of inclusion caused by the variety of meanings of inclusive education within national practices, by the lack of coherence and consistency of policies, by large variations in the formation of the competencies of professionals, by inclusive pedagogies and resources, and by the yet inconclusive results of research data on the effects that inclusion has on the learning and development of pupils.

The inclusion of all children and the ensuring of educational progress for every pupil implies that change has to occur in all aspects - legislative, structural and institutional, in terms of mindset/ behaviour. Hence, the model of inclusion cannot be imported and the strategy of a given country for 
identifying its own perspective on inclusion has to take into consideration, according to analysts (Ainscow, 2016), the following elements: inclusion is a continuous process; inclusion is concerned with the identification and removal of barriers; inclusion refers to the presence, participation and achievement of all students; inclusion involves a particular emphasis on those groups of learners who may be at risk of marginalisation, exclusion or underachievement.

At the level of the European Union, the Report on the Implementation of ET 2020 - the Strategic Framework for European Cooperation in Education and Training proposes that inclusive education, equality, equity, nondiscrimination and the promotion of civic competences be placed among the priorities of European cooperation in the field of education and training (EU, 2015).

Despite several formal rulings in favour of inclusion, at national levels the tensions and disputes arising from the lack of coherence and from competing interests negatively affect their implementation (The European Agency for Special Needs and Inclusive Education, 2018). The studies have identified a strong correlation between national traditions and practices for inclusion, which means that it is very difficult for countries and schools to implement an advanced model of inclusive educational policies in a short timeframe.

\section{Educational exclusion and the phenomenon of early school leaving}

The extent to which a given educational system manages to combat inequities in terms of exclusion constantly refers to the early school leaving indicator. In accordance with international and European practice (Council Recommendation, 28.06.2011), early school leaving is defined to describe the situation of individuals aged 18-24 who leave the education and training system at the level of secondary education or before this level. According to the strategy aimed at reducing early school leaving in Romania, the category of young people who are not included in the education system hence consists of those who have concluded only the pre-school education, primary school or no more than two years of upper secondary education 
(ISCED - the International Standard Classification of Education), respectively those young people who completed a level of pre-vocational and vocation training which did not allow them to obtain a Capacity Certificate. Diminishing early school leaving is in line with both the ET 2020 objective of intelligent growth through the improvement of education and professional training levels, and with the objective of inclusive growth, through dealing with one of the most significant risk factors in terms of unemployment, poverty and social exclusion, with a reduction target at EU level set to less than $10 \%$ by the year 2020 .

To a larger extent than social interventions, a deep understanding of the phenomenon of participation in education and actions with a direct impact on the educational process stand as conditions for increasing quality and equity in the educational system (UNICEF-ISE, 2017).

\subsection{Educational exclusion and the excluded}

As in the case of inclusion, educational exclusion can be understood in a context broader than the usual one, referring to all the situations/ strains that may result in temporary, long-term or permanent exclusion (including the disciplinary type) or referring to full participation in education (caused by difficulties in interacting or by the feeling of not being valued by others, difficulties in understanding what is taught in school, etc.).

The concept of vulnerability is related to exclusion and it refers to individuals or groups who are more exposed to risk, who need specific support or benefits in order to compensate for health-related, economic or social drawbacks. In an extensive study on the conceptualisation of vulnerability (Virokannas et al., 2020), the authors bring to our attention several topics related to vulnerability and the critical comments on this concept which has become fashionable. According to them, the largest number of studies referred to the groups of population in situational vulnerability, among which the youth transitioning to adult life hold an important place, especially those who are likely to develop risk-increasing behaviours. Among them, naturally/ born vulnerable groups were identified on criteria especially relating to gender and disability. In general, we can distinguish among three fundamental areas 
that can result in the vulnerability of young people, a vulnerability that tends to unfold into a downward spiral (World Bank, 2005), so that with each shock, the child goes down further reaching a new level of vulnerability, and with each level he/ she is exposed to a host of new risks: material aspects shelter, food, clothing, money, medical care and education; emotional aspects - care, love, support and emotional control; social aspects - not belonging to a social group of equals, lack of role models to follow or guidance in difficult situations and risks in one's close environment. Based on data from the national longitudinal study on the youth in the US, Berzin (2010) aimed to identify the patterns in the development of the youth transitioning to adult life based on their level of education and social outcomes. His analysis shows that demographic characteristics, the main features of the growing environment at home and psychosocial resources can predict membership to risk groups; in this regard, involvement in youth-serving government systems is associated with poorer outcomes and remains salient when considered with other risk factors (Berzin, 2010).

Regarding the debatable aspects of operating with concepts such as vulnerable, excluded, marginal or at risk, we should recall the fact that these practices result in a delimitation between those inside and outside the norms of competence and success (Dahlberg, 2016, p. 128) and in differentiation procedures which can generate counterproductive classification and labelling such as the NEET (Not in Education, Employment or Training). Elina Virokannas et al. (2020) conclude that it is necessary to admit the temporal, situational, relational and structural nature of vulnerability, and that social research should be focused on vulnerabilityinducing life situations and on the role of social or educational services/ interventions in the reduction, but also in the accumulation or (re)production of vulnerability.

In accordance with this perspective, using the level of visibility of the data regarding children (visible/ invisible children), UNICEF designed a detailed framework for the categories of children and adolescents either excluded or at risk of exclusion. The UNICEF multidimensional model of exclusion makes the difference between the children/ adolescents who are not included in the education system and those at risk of early school leaving and distinguish among the children/ adolescents who are out of school as a result 
of early school leaving, the children/ adolescents who enrol late in school and the children/ adolescents who will never go to school (UNICEF, 2017, pp. 5-6).

\subsection{The slippery realities and the early school leaving policies}

As mentioned above, in accordance with international and European practice, early school leaving refers to adolescents and young people who leave the training and school system at the level of secondary education or before this level. The complementary concept of school dropout is one of the severe forms of non-participation in school and its estimation can be a relevant indicator for an in-depth understanding of the phenomenon of early school leaving, however, the methodological differences arising among states when it comes to its definition and calculation limit its relevance at an international level. Moreover, the impossibility of a realistic assessment on the phenomenon of school dropout, hence on combating it, is exacerbated by the non-harmonisation of the definitions with which each national system operates, as in the case of Romania (UNICEF-ISE, 2017).

Alternatively, one of the methods used is the analysis of school dropout cohort analysis, focused on a given generation throughout a full school cycle. This indicator calculated for Romania as well, with the support of UNICEF (UNICEF-ISE, 2017), offers a more accurate perspective on this phenomenon, allowing for a better substantiation of the set of existing data at the level of the system and educational policies.

A recent analysis (Tuparevska et al., 2019) carried out on the most important European policy decisions in the field of education, shows that most of the measures are aimed at early school leavers and they are offered a wide range of measures ranging from second chance schools and opportunities to high-quality early childhood education and care. Among those, the measure on the development of basic skills is one of the most invoked directions when referring to the low-skilled and early school leavers. The New Skills Agenda for Europe (EC, 2016, p. 5) suggests to 'where possible - develop a wider set of skills leading to an upper secondary education qualification', but it is again literacy, numeracy and digital skills that is on 
offer for vulnerable groups such as early school leavers and the low-skilled. A series of authors emphasizes that a focus on critical literacy (which allows one to read the world, i.e. Freire) will not only ensure the democratic skills for people which are so necessary to making these groups visible, but it will also make the discourse on basic skills less individualistic and competitive (Tuparevska et al., 2019). The same study notes that despite EU policies for reducing social exclusion, Eurostat data show that the statistical indicators of poverty and social exclusion (AROPE) have not significantly improved since the launch of Europe 2020. Hence there are certain groups that continue to face barriers when it comes to benefiting from the measures provided through various programmes or risk of being excluded from learning opportunities, such as the unemployed, Roma, the persons who live in rural or distant areas, disabled persons, single parents, the homeless, former criminals, accumulating the initial disadvantage and passing it from one generation to another.

\subsection{The approach of early school leaving in Romania}

Unlike individual data processing, i.e. beyond our personal or group experience (which could be either positive or negative), when it comes to decision making in a national education system, statistics is the one to set reality.

According to the Eurostat 2019 data, the early school leaving rate (for ages 18-24) in Romania, situated at 16.4\% in 2018 (down from 18.1\% in 2017), remains among the highest in the EU. Its value is significantly above the EU average (10.6\%) and above the national target for $2020(11.3 \%)$. In 2017, the participation of children aged between 4 and the mandatory school age of 6 slightly increased to $89.6 \%$, a value still under the $95 \%$ reference value of Education and Training 2020 (EC, Education and Training Monitor, 2018).

The Country Report Romania 2019 identifies the main realities leading to the poor educational performance: a low level of educational expenditure (among the lowest in the EU), especially when it comes to early childhood education, considered essential for preventing early school leaving, a low 
level of engagement in the system of childhood care and education (also due to lack of facilities); challenges regarding the development of basic and digital skills; a weak correlation between the school network and demographic tendencies; the insufficient development of teachers' competencies to apply an approach that is focused on the pupil; the persistence of rural-urban disparities; limited access to quality education for vulnerable groups, especially for disabled persons and Roma. The data shows limited government financial commitment to education (3.7\% of the GDP in 2017, compared to the EU average of $4.7 \%$, Eurostat, 2019); in 2016, the level of educational expenditure of public and private educational institutions for each pupil / student was of approximately 2,074 EUR, compared to the EU average of 6,869 EUR. When it comes to infrastructural and institutional development, Romania drafted a strategy for the modernisation of educational infrastructure (2018-2023) in order to approach significant efficiency-related and equityrelated challenges: $10 \%$ of schools are overcrowded (especially in urban areas), whereas $60 \%$ are underused (especially in rural areas); school transportation services are generally insufficient and inadequate, whereas accessibility worsens as pupils go through the school system.

When it comes to participation, significant disparities at ethnic (especially for Roma) and territorial (especially in rural areas) levels are mentioned. Whereas $95 \%$ of children aged 7-14 are enrolled in primary and secondary education, this is true for only $77 \%$ of Roma children, and only $34 \%$ of Roma children aged 15-18 participated in secondary higher education (FRA, 2016).

According to the 2018 Education and Training Monitor, Romanians are significantly behind the EU average when it comes to the basic skills that predict the continuation and completion of studies. Although Romania's PISA scores improved starting with 2006 and dropped in 2018 in comparison to the ones in 2015, they still remain significantly lower than those of other states in the EU. The implementation of the competence-based curriculum is in progress and it has encountered difficulties. In addition, teachers' skills of practicing a student-centered pedagogy are insufficiently focused on the challenges in the classroom, including on the support of children with learning deficiencies or of children at dropout risk (ISE, 2018). 
Based on the European Union's (EU) jobs and growth strategy for 2010-20 (EU 2020), Romania has developed five national strategies in the field of education, focused on the great challenges for the Romanian education system: reducing early school leaving (2015-2020), improving the quality of tertiary education (2015-2020) and the VET(2016-2020), the promotion of lifelong learning (2015-2020) and investments in the infrastructure of educational institutions (2018-2023).

To approach the critical topics mentioned above, the National strategy for the reduction of early school leaving 2015-2020 highlighted the importance of the early childhood years in child development and school readiness, as a prerequisite for success in school and it focused on the concept of integrated response in terms of policies and services from all relevant fields (education, healthcare, social protection, etc.), with the horizontal and vertical coordination between the relevant public and private actors. The programmes proposed in this pillar refer to the increasing of enrolment rates in early childhood education, primary and secondary lower education. In the context of the expansion of participation in education, it proposes granting special attention to the progressive expansion of preschool education (ages 3-5) in order to obtain a universal enrolment rate. Additional results on enrolment in the primary and secondary inferior cycles are also proposed for approaching disparities in learning outcomes among the various target groups of children aged 11 to 17, especially for those in precarious economic environments from rural areas, Roma children and other minority groups through: developing systems for early detection and intervention; the consolidation, expansion and personalisation of counselling services and the introduction of promotion mechanisms for educational student-centered programmes, as well as of other types of programmes for keeping pupils in the system.

A series of other additional strategies has been developed. The Strategy on poverty reduction and social inclusion 2016-2020 renders explicit the main government objective of insuring equality of opportunities for the promotion of quality education for all, paying special attention to the quality of education and professional training and to their relevance for both the necessities of the labour market and those of individuals. It also aims at improving teachers' abilities to efficiently provide an inclusive education 
to Roma children and to eliminate the segregation, discrimination and negative stereotyping of Roma children in schools. Increasing the access of children from marginalised areas represents another critical topic calling for: the improvement of facilities, qualified teachers, educational materials and modern equipment. Also, according to the National Youth Strategy 2015-2020 the objectives specific to the education pillar refer to ensuring access to education and a quality formal and non-formal education for all the youth and adolescents; the improvement of the non-formal education options; ensuring a practical relevance for the competencies acquired through formal and non-formal education.

When we refer to outcomes, a relevant fact may be that in the year 2017 less than a quarter of the allocated budget was spent for the four educational strategies. Along with financial limitations, delayed decision making and their implementation, as well as the discrepancies in the changes recorded for the rural area and the urban area (the case of early school leaving) limit the development of these strategies.

\section{Discussions}

As we have seen above, the period after the years 2014/2015 meant an accentuation of equity-related aspects in EU policies, especially the measures on reducing early school leaving, a fact that also echoed in national policies, as in the case of Romania. On the other hand, the EU and OECD statistics, in spite of their many errors and reporting ambiguities, serve the main role of adjusting policies at national levels, identifying the action areas and lending them legitimacy. Some authors talk about a transition of educational systems toward Europeanisation (Alexiadou et al., 2019), through which the groups of disadvantaged youngsters, such as Roma, now have a chance to not become lost because of legislation and policies.

The discussion in our study of the three initial concepts - quality, equity, inclusion - revealed that a large part of international institutions, school and government-level decision makers, researchers and practitioners consider that participation in school until the tertiary level represents a clear measure of / result of quality and equitable education and a guarantee for 
social and personal success. This simplistic view on the educational path and transitions from a period of schooling to another or to the labour market has been the basis for the policies and programmes. We also saw that the problematisation by specialists and practitioners regarding the various aspects of designing and experiencing these educational transitions, reflect their processual nature and the necessity of an integrated approach (at the intersection of education, healthcare, social and labour policies).

In Romania, the situation of those who leave/ do not participate in school is 'traditionally' tolerated as a normal loss in school selection/ evolution. This rhetoric is less likely to change in the near future, in the context of conceptualisations that leave room for defining the problematic aspects of education in stigma terms, with rather socially oriented solutions. The UNICEF-ISE study (2017) suggests that the measures that reached the disadvantaged groups (from a territorial, economic and ethnic perspective) were rather focused on approaching the social barriers to participation in school and the high rate of early school leaving is likely to persist. It mentions that despite the policies for improving the quality of education in this past decade, among which the designing of a new curriculum, the promotion of measures for an internal assurance of the quality of school, investments in school/ educational infrastructure or the implementation of in-service learning programs for teachers and school management, the interventions were not sufficiently correlated.

In this complex and contradictory space, in the context of the discursive avalanche and of the pressure of the policies directly mandating schools to address issues of diversity, inclusion and equity, teachers stand as the most important variable of schools when it comes to the valuing of inter-individual differences, with clear effects on the outcomes (Ewing, 2013, as cited in Webster \& Ryan, 2018).

A study on unexcused school absenteeism carried out in a community in Sweden (Ekstrand, 2015) highlighted that the pupils who are absent from school usually experience and regard school work and education as lacking in meaning, in challenges, and they react to this by contesting or ignoring it. The positive approach on school culture and of pedagogy, highlighting the strengths (and not the weaknesses) is a process implying the need for change 
at all levels - of the government, the community, the school organisation and among the personnel. The success in Romania of the program A second chance addressed to those who resume their studies after having dropped out or to those who have never been enrolled in school confirms the theses according to which pupils need adults to take care of them, respect them and involve them both socially and educationally. On the other hand, ensuring basic skills represents a necessary condition for learning, but it is also necessary to add the ability of self-reflection and decision-making which, along with self-esteem, creates the feeling of being capable of tackling schoolwork, and even the capacity to resume going to school (Ekstrand, 2015).

\section{References}

- Ainscow, M. (2016). Diversity and Equity: A Global Education Challenge. New Zealand Journal of Educational Studies, 51, 143-155.

https://doi.org/10.1007/s40841-016-0056-x

- Alexiadou, N., Helgøy, I., \& Homme, A. (2019). Lost in transition - policies to reduce early school leaving and encourage further studying in Europe. Comparative Education, 55(3), 297-307.

https://doi.org/10.1080/03050068.2019.1619327

- Berzin, S. (2010). Vulnerability in the transition to adulthood: Defining risk based on youth profiles. Children and Youth Services Review, 32(4), 487-495.

https://doi.org/10.1016/j.childyouth.2009.11.001

- Commission of the European Communities (CEC). (2006). Efficiency and equity in European education and training systems (COM(2006) 481 final). Commission of the European Communities.

- Council of the European Union. (2011). Recomandarea Consiliului din 28 iunie 2011 privind politicile de reducere a părăsirii timpurii a şcolii. https://eur-lex.europa.eu/legal-content/RO/TXT/PDF/?uri= CELEX:32011H0701(01)\&from=EN

- Dahlberg, G. (2016). An ethico-aesthetic paradigm as an alternative discourse to the quality assurance discourse. Contemporary Issues in Early Childhood, 17(1), 124-133. https://doi.org/10.1177/1463949115627910

- Doherty, G. (2008). On quality in education.Quality Assurance in Education, 16(3), 255-265. https://doi.org/10.1108/09684880810886268

- Edley, C., Koenig, J., Nielsen, N., \& Citro, C. (Eds.). (2019). Monitoring Educational Equity. National Academies Press. https://doi.org/10.17226/25389

- Ekstrand, B. (2015). What it takes to keep children in school: a research review. Educational Review, 67(4), 459-482. 
https://doi.org/10.1080/00131911.2015.1008406

- Elken, M., \& Stensaker, B. (2018). Conceptualising quality work in higher education. Quality in Higher Education, 24(3), 189-202. https://doi.org/10.1080/13538322.2018.1554782

- EU. (2015). Joint Report of the Council and the Commission on the implementation of the strategic framework for European cooperation in education and training (ET 2020) - New priorities for European cooperation in education and training.

https://eur-lex.europa.eu/legal-content/EN/ALL/?uri=CELEX\% 3A52015XG1215\%2802\%29

- European Commission/Eurydice România. (n.d.). Reforme în derulare şi evolu ii in materie de politici. https://eacea.ec.europa.eu/national-policies/eurydice/ content/ongoing-reforms-and-policy-developments-56_ro

- European Agency for Special Needs and Inclusive Education. (2014). Five Key Messages for Inclusive Education. Putting Theory into Practice.

https://www.european-agency.org/sites/default/files/Five\%20Key\% 20Messages\%20for\%20Inclusive\%20Education.pdf

- European Agency for Special Needs and Inclusive Education. (2018). Supporting Inclusive School Leadership: Literature Review.

https://www.european-agency.org/sites/default/files/SISL_Literature_Review.pdf

- European Commission. (2016). The new Skills Agenda for Europe. https://ec.europa.eu/social/main.jsp?catId=1223

- European Commission. (2018). Education and Training Monitor 2018, Country analysis: Romania. https://ec.europa.eu/education/sites/education/files/ document-library-docs/volume-2-2018-education-and-training-monitor-countryanalysis.pdf

- European Commission. (2019). Country Report Romania 2019 Including an In-Depth Review on the prevention and correction of macroeconomic imbalances. https://ec.europa.eu/info/sites/info/files/file_import/2019-europeansemester-country-report-romania_ro.pdf

- European Union Agency for Fundamental Rights (FRA). (2016). Second European Union Minorities and Discrimination Survey (EU-MIDIS II) Roma Selected findings. https://fra.europa.eu/sites/default/files/fra_uploads/fra-2016eu-minorities-survey-roma-selected-findings_ro.pdf

- Eurostat. (2019). Eurostat 2019 data. https://ec.europa.eu/eurostat/data/database; https://ec.europa.eu/eurostat/statistics-explained/images/e/e7/Total_general_ government_expenditure_on_education\%2C_2017_\%28\%25_of_GDP\%29.png

- Göransson, K., \& Nilholm, C. (2014). Conceptual Diversities and Empirical Shortcomings - ACritical Analysis of Research on Inclusive Education. European Journal of Special Needs Education, 29(3), 265-280.

https://doi.org/10.1080/08856257.2014.933545 
- Institutul de Ştiin e ale Educa iei (ISE). (2018). Raport privind nevoile de formare ale cadrelor didactice din învă ământul primar şi gimnazial.

https://www.educred.ro/noutati/nevoile-cadrelor-didactice-pentru-formarea-indomeniul-abilitarii-curriculare/

- Jones, L., Osgood, J., Holmes, R., \& Urban, M. (2016). Reimagining quality in early childhood. Contemporary Issues in Early Childhood, 17(1), 3-7. https://doi.org/10.1177/1463949115627912

- Laurie, R., Nonoyama-Tarumi, Y., Mckeown, R., \& Hopkins, C. (2016). Contributions of Education for Sustainable Development (ESD) to Quality Education: A Synthesis of Research. Journal of Education for Sustainable Development, 10(2), 226-242. https://doi.org/10.1177/0973408216661442

- Levin, B. (2003). Approaches to Equity in Policy for Lifelong Learning. Equity in Education.

http://www.oecd.org/education/innovation-education/38692676.pdf

- Moss, P. (2016). Why can't we get beyond quality? Contemporary Issues in Early Childhood, 17(1), 8-15. https://doi.org/10.1177/1463949115627895

- Nikel, J., \& Lowe, J. (2010). Talking of fabric: a multi dimensional model of quality in education. Compare: A Journal of Comparative and International Education, 40(5), 589-605. https://doi.org/10.1080/03057920902909477

- PISA. (2019). Rezultatele elevilor din România la evaluarea interna ională PISA 2018. https://www.edu.ro/rezultatele-elevilor-din-rom\%C3\%A2nia-laevaluarea-interna\%C8\%9Bional\%C4\%83-pisa-2018

- Tuparevska, E., Santibáñez, R., \& Solabarrieta, J. (2019). Equity and social exclusion measures in EU lifelong learning policies. International Journal of Lifelong Education, 39(1), 5-17.

https://doi.org/10.1080/02601370.2019.1689435

- Virokannas, E., Liuski, S., \& Kuronen, M. (2020). The contested concept of vulnerability - a literature review. European Journal of Social Work, 23(2), 327-339. https://doi.org/10.1080/13691457.2018.1508001

- Webster, S., \& Ryan, A. (2018). Equity and (critical) diversity. In S. Webster \& A. Ryan (Eds.), Understanding Curriculum: The Australian Context (pp.126-143). Cambridge University Press.

- UNESCO. (2005). Contributing to a more sustainable future: quality education, life skills and education for sustainable development.

https://unesdoc.unesco.org/ark:/48223/pf0000141019

- UNESCO. (2008). Inclusive education: the way of the future. Conclusions and recommendations of the 48th session of the international conference on education (ICE). Geneva.

http://www.ibe.unesco.org/fileadmin/user_upload/Policy_Dialogue/48th_ICE/ CONFINTED_48-5_Conclusions_english.pdf 
- UNESCO. (2015). Education 2030: Towards inclusive and equitable quality education and lifelong learning for all. Paris.

https://unesdoc.unesco.org/ark:/48223/pf0000233029/PDF/233029eng.pdf.multi

- UNICEF - ISE. (2017). La şcoală. O privire asupra participării la educa ie folosind analiza pe cohortă. Editura Alpha MDN. http://www.unicef.ro/wp-content/uploads/Studiu-Cohorta.pdf

- UNICEF. (2017). Cadrul de monitorizare al copiilor afla i în afara sistemului de educa ie. Monitorizarea copiilor afla i în afara sistemului de educa ie şi a copiilor cu risc de abandon şcolar din România. http://www.unicef.ro/wpcontent/uploads/Cadru-de-monitorizare-a-copiilor-aflati-in-afara-sistemului-deeducatie-Romania_2017.pdf

- World Bank. (2005). Children \& Youth. A Resurse Guide. http://siteresources.worldbank.org/INTCY/Resources/ResourceGuide.pdf

The online version of this article can be found at: http://revped.ise.ro/category/2020-en/

\section{(c) EY-NG-SA}

This work is licensed under the Creative Commons Attribution-NonCommercial-ShareAlike 4.0 International License.

To view a copy of this license, visit http://creativecommons.org/licenses/by-nc-sa/4.0/ or send a letter to Creative Commons, PO Box 1866, Mountain View, CA 94042, USA.
Versiunea online a acestui articol poate fi găsită la: http://revped.ise.ro/category/2020-ro/

\section{$(c c)$ BY-NG-SA}

Această lucrare este licen iată sub Creative Commons Attribution-NonCommercial-ShareAlike 4.0 International License.

Pentru a vedea o copie a acestei licen e, vizita $i$ http://creativecommons.org/licenses/by-nc-sa/4.0/ sau trimite i o scrisoare către Creative Commons, PO Box 1866, Mountain View, CA 94042, SUA. 


\title{
POZI IONAREA ELEVILOR CU STATUS SOCIO-ECONOMIC SCĂZUT FA Ă DE ÎNVĂ AREA ŞCOLARĂ - STUDIU DE CAZ -
}

\section{Octavia Borş*}

\author{
Centrul Na ional de Politici şi Evaluare în Educa ie, \\ Unitatea de Cercetare în Educa ie, \\ Bucureşti, România \\ octavia.bors@gmail.com
}

\section{Rezumat}

În România, persoanele cu un nivel ridicat de educa ie este mai probabil să dobândească un status ocupa ional mai înalt decât tatăl lor, o dată cu înaintarea în carieră (Jecan \& Pop, 2012) şi venituri mai mari cu fiecare an de şcoală absolvit (Varly et al., 2014). Totodată, decalajul dintre rezultatele elevilor reflectă inegalită ile socio-economice dintre aceştia (Botezat, 2019; Feşnic, 2019; Ivan, 2019; Tufiş, 2008; oc, 2016). Prezentul studiu de caz descrie şi pune în discu ie reprezentările profesorilor despre elevii cu status socio-economic scăzut şi pe cele ale elevilor despre învă are, într-un colectiv de clasa a VIII-a. Analiza prezentată în acest articol include date colectate în februarie 2018 prin interviuri cu profesori, dirigintele clasei şi elevi, respectiv prin observare neparticipativă la ore, în pauze şi în cadrul unei şedin e cu părin ii. Studiul de caz dezvăluie că, în discursul profesorilor, elevii sunt reprezenta i ca „,dezinteresa i” fa ă de educa ia lor formală, iar elevii, la rândul lor, se prezintă ca „leneşi” pentru că nu îşi fac temele, nu înva ă acasă şi/sau nu răspund suficient în clasă. Astfel, în cazul studiat, elevii cu status socio-economic scăzut par să îşi însuşească discursul deficitar al profesorilor, să îşi plaseze nevoile individuale, inclusiv cele de sprijin al învă ării, într-o zonă de ilegitimitate şi să-şi reprezinte învă area ca un act mai degrabă individual. Elevii opun rezisten ă la ore, dar reprezentările lor despre învă are nu contestă autoritatea pedagogică, ci dezvăluie eforturile acestora de auto-disciplinare.

* Cercetător ştiin ific, Centrul Na ional de Politici şi Evaluare în Educa ie (CNPEE), Unitatea de Cercetare în Educa ie, Bucureşti, România. 
Cuvinte-cheie: clasă socială, identitate, învă are şcolară, sprijin, status socioeconomic.

\section{Abstract}

In Romania, highly educated people are more likely to acquire a higher occupational status than their parents as they progress in their career (Jecan \& Pop, 2012) and higher incomes with every completed school year (Varly et al., 2014). On the other hand, the gap between the students' results mirrors the socio-economic inequalities among them (Botezat, 2019; Feşnic, 2019; Ivan, 2019; Tufiş, 2008; oc, 2016). In order to gain an in depth understanding of how inequality is perpetuating, the case study this article is based on aims to explore, describe and discuss the teachers' representations on students with low socio-economic status and the students' representations on learning. The analysis uses data collected in February 2018 through interviews with teachers, the class's tutor, students and nonparticipatory observation. The case study reveals that in the teachers' discourse, the students are presented as lacking interest and responsibility for studying. Also, the students describe themselves as 'lazy' because they do not do their homework or answer the teachers' questions. A closer look at these ideas suggests that the students are identifying with their teachers' deficit narrative; also they disregard their need for support in learning and think of learning as an individual act. In the classroom the students display resistance, however their narrative about learning does not question the pedagogic authority and also reveals their self-disciplinatory efforts.

Keywords: learners' identity, learning, social class, socio-economic status, support.

\section{Introducere}

Studiile realizate pe popula ie românească arată că între educa ie şi statusul socio-economic al indivizilor există o rela ie în ambele sensuri. În România, conform analizei lui Varly et al. (2014), cu fiecare an de şcoală absolvit, veniturile unei persoane cresc cu 8,5\% - 9,07\%. Totodată, Jecan şi Pop (2012) arată că, deşi primul loc de muncă se corelează cu statusul ocupa ional al tatălui, odată cu înaintarea în carieră, cu fiecare nivel de educa ie dobândit, românii au locuri de muncă cu status mai ridicat.

Pe de altă parte, în cazul ării noastre, se confirmă efectul Coleman (1966), 
variabilele care au cea mai mare putere explicativă în rela ie cu performan a şcolară a elevilor români fïind educa ia părin ilor (Tufiş, 2008), dotarea gospodăriilor, compozi ia socială a claselor şcolare (educa ia ta ilor) şi tipul unită ilor de învă ământ (Hatos, 2008), ocupa ia părin ilor şi bunurile materiale ( oc, 2016), capitalul cultural al părin ilor - numărul de căr i de inute (Botezat, 2019; Feşnic, 2019; Ivan, 2019), statusul ocupa ional al părin ilor (Botezat, 2019). Aceste analize ne oferă o imagine macro despre rela ia dintre statusul socio-economic al elevilor români şi performan a şcolară, însă din literatură lipsesc cercetările micro care ar putea să contribuie la în elegerea rela iei dintre inegalită ile sociale şi educa ie.

Încă din anii '70 este cunoscută şi studiată ideea că ac iunea pedagogică impune un arbitrar cultural, excluzând elevii care nu de in abilită ile şcolare (Bourdieu \& Passeron, 1978) sau limbajul elaborat (Bernstein, 1978) specific claselor privilegiate. Cercetări recente arată că profesorii nu se raportează explicit la apartenen a de clasă socială a elevilor, însă acest lucru le influen ează judecata (Dunne \& Gazeley, 2008), abordarea pedagogică (Lupton \& Hempel-Jorgensen, 2012) şi practicile de lucru la clasă (Devine \& McGillicuddy, 2016). Dunne şi Gazeley (2008) au descoperit că profesorii nu etichetează elevii în termeni de clasă socială, însă când explică situa iile de eşec şcolar, dacă elevul apar ine clasei muncitoare, cei intervieva i localizează cauza la nivelul familiei, iar dacă elevul apar ine clasei de mijloc, problema este plasată la nivelul didactic/al şcolii, profesorul considerând că stă în puterea lui să intervină. Lupton şi Hempel-Jorgensen (2012) arată că profesorii care predau copiilor ce apar in clasei muncitoare sunt adep i ai pedagogiei ,,perfomative”, fiind preocupa i de evaluările externe, de men inerea disciplinei, oferind autonomie redusă elevilor şi grupându-i în func ie de rezultate. Devine şi McGillicuddy (2016) au descoperit că profesorii descriu copiii care provin din clasa muncitoare punând accent pe deficitele acestora, formulează aşteptări mai scăzute pentru ei şi se centrează pe securizarea emo ională a acestora în detrimentul învă ării.

În ceea ce priveşte experien a şcolară a elevilor din diverse clase sociale, studiile dovedesc că, în timp ce elevii din clasa de mijloc simt că apar in şcolii (Bourdieu, 1999; Khan, 2011; Lareau, 2000) şi îşi exprimă nevoile cu uşurin ă, captând aten ia profesorilor (Calarco, 2011), cei care apar in clasei muncitoare consideră că trebuie să renun e la modul lor de a fi, pentru a 
avea succes şcolar (Reay, 2001). De asemenea, cei din urmă nu recunosc dimensiunea structurală a inegalită ilor, ci atribuie dificultă ile lor economice şi educa ionale factorilor personali sau familiali (Freie, 2014). Mai mult, ei îşi construiesc identitatea de elev în acord cu ideile şi practicile neoliberale meritocra ia, ubicuitatea oportunită ilor, individualismul, consumerismul, idealizarea statutului de clasă mijlocie (Freie, 2014; Stahl, 2016), reconciliind contradic ia dintre acestea şi condi ia lor socială, prin însuşirea ideii că sunt inferiori (Reay, 2001) şi nu îşi doresc mai mult decât independen ă şi un statut modest (Stahl, 2016).

Prezentul studiu de caz arată că în reprezentările profesorilor, elevii cu status socio-economic scăzut sunt ,dezinteresa i” fa ă de educa ia formală şi că, la rândul lor, elevii se prezintă ca „leneşi”. Explorarea acestor idei în profunzime sugerează că, în cazul studiat, elevii cu status socio-economic scăzut se auto-pozi ionează ca persoane care merită să fie sprijinite în învă are numai în măsura în care depăşesc alte nevoi individuale şi răspund aşteptărilor şcolii, în drumul lor spre o medie bună la evaluarea na ională, un liceu competitiv şi ocupa ii prestigioase.

\section{Designul cercetării}

Prin această cercetare s-a dorit explorarea reprezentărilor profesorilor despre elevii cu status socio-economic scăzut, precum şi a reprezentărilor celor din urmă despre şcoală. În cadrul acestui studiu, clasa (şcolară) este privită ca un spa iu cultural unde elevii îşi formează identitatea în rela ie cu ceilal i (Holland et al., 1998; Wenger, 1998) şi dispozi iile lor de clasă socială (Bourdieu, 1999), inclusiv o reprezentare despre învă area şcolară şi locul lor în acest proces. Pentru a surprinde reprezentările particulare ale elevilor cu status socio-economic scăzut şi ale profesorilor lor, s-a optat pentru o abordare metodologică calitativă (Creswell, 2014), de tip studiu de caz etnografic (Parker-Jenkins, 2016). Această abordare presupune restrângerea grani elor cercetării la o unitate de analiză (caz), spre investigarea holistică şi în context a cazului (Stake, 2005), într-un timp scurt (de la câteva zile, la câteva luni) şi care mobilizează tehnici şi intui ia etnografică: observare şi interviuri în teren, investigarea culturii grupului, interpretarea limbajului şi a practicilor subiec ilor prin referire la cultura grupului, pozi ionarea etnografului (Parker-Jenkins, 2016). 
Colectarea datelor s-a desfăşurat pe parcursul a 2 săptămâni, în februarie 2018 şi a inclus 6 vizite la şcoală. Datele colectate reprezintă rezultatul a 17 ore de observare la ore, în pauze şi în cadrul unei şedin e cu părin ii, respectiv interviuri cu dirigintele clasei, 5 profesori şi 14 elevi. Observarea la ore a fost nestructurată şi neparticipativă - datele au fost înregistrate prin noti e la fa a locului şi prin completarea unui jurnal zilnic de teren despre dialogul din clasă, apelativele folosite, limbajul non-verbal, detalii de organizare şi folosire a spa iilor sau a anumitor obiecte. Interviurile desfăşurate au fost de tip semi-structurat, urmărindu-se perspectiva profesorilor şi elevilor privind participarea şi performan a şcolară, obiceiurile de petrecere a timpului, practicile de predare. Interviurile cu elevii s-au desfăşurat individual sau în grupuri de două-trei persoane, formate la solicitarea şi alegerea responden ilor.

În cercetare s-a optat pentru selec ia subiectivă a unui caz unic, potrivit pentru a cerceta în profunzime reprezentările elevilor cu status socioeconomic scăzut şi pe cele ale profesorilor acestora (Small, 2009). Şcoala unde s-a desfăşurat cercetarea a fost selectată astfel încât să fie localizată într-o zonă industrială, presupunându-se că va include elevi cu status socioeconomic scăzut, dar şi în func ie de criteriul accesibilită ii. Clasa a VIII-a C, considerată cazul prezentei cercetări şi analize, a fost aleasă la recomandarea consilierului şcolar. În reprezentarea acestuia, elevii din această clasă sunt ,dezavantaja i”, referindu-se prin asta la faptul că apar in unor familii monoparentale, cu istoric de violen ă domestică, alcoolism şi/ sau aflate în sărăcie. După cum se poate vedea în Tabelul nr. 1, relatările elevilor despre ocupa ia şi educa ia părin ilor au confirmat relevan a cazului selectat pentru cercetare, cei mai mul i elevi din clasă având status socioeconomic scăzut.

La momentul colectării datelor, elevii din clasa a VIII-a C aveau 15-16 ani şi erau în semestrul al doilea din ultimul an de gimnaziu. Totodată, colectivul avea 16 elevi: 9 din componen a ini ială (de 22 elevi, dintre care 12 s-au transferat în alte colective sau şcoli), 2 transfera i de la alte şcoli şi 4 repartiza i aici pentru a repeta clasa a VI-a (trei din aceeaşi şcoală, unul dintr-o altă şcoală). 
Tabelul nr. 1. Ocupa ia şi nivelul de educa ie absolvit al părin ilor

\begin{tabular}{|c|c|c|c|c|c|}
\hline \multirow{2}{*}{$\begin{array}{l}\text { Nr. } \\
\text { Crt. }\end{array}$} & \multirow{2}{*}{ Pseudonim } & \multicolumn{2}{|c|}{ Ocupa ia părin ilor } & \multicolumn{2}{|c|}{ Nivelul de educa ie absolvit } \\
\hline & & Tata & Mama & Tata & Mama \\
\hline 1 & Marius & Şofer & $\begin{array}{l}\text { Operator, apoi mic } \\
\text { antreprenor } \\
\text { (firmă de între inere } \\
\text { lifturi) }\end{array}$ & 12 clase & 12 clase \\
\hline 2 & Alin & - & Farmacistă & Universitar (licen ă) & Universitar (licen ă) \\
\hline 3 & Cătălin & $\begin{array}{l}\text { Paznic } \\
\text { (*violen ă în familie) }\end{array}$ & $\begin{array}{l}\text { Îngrijitoare în } \\
\text { străinătate }\end{array}$ & - & 12 clase \\
\hline 4 & Bogdan & $\begin{array}{l}\text { Paznic } \\
(* \text { alcoolism })\end{array}$ & Neocupată & - & 12 clase \\
\hline 5 & Dragoş & $\begin{array}{l}\text { Muncitor în } \\
\text { construc ii }\end{array}$ & Muncitor în confec ii & 10 clase & 9 clase \\
\hline 6 & Nicoleta & $\begin{array}{l}\text { Antreprenor } \\
\text { (construc ii) }\end{array}$ & Neocupată & 12 clase & 8 clase \\
\hline 7 & Alexandra & Fermier & Contabilă & Universitar (doctorat) & Universitar (master) \\
\hline 8 & Maria & - & - & 10 clase & 10 clase \\
\hline 9 & Dan & $\begin{array}{l}\text { Fermier } \\
\text { (*violen ă în familie) }\end{array}$ & Vânzătoare & 12 clase & 12 clase \\
\hline 10 & Ionela & Zilier în construc ii & Liftieră & 12 clase & - \\
\hline 11 & Geanina & Zugrav & $\begin{array}{l}\text { Femeie de serviciu şi } \\
\text { spălătoreasă }\end{array}$ & 8 clase & 8 clase \\
\hline 12 & Nicolae & Tehnician Metrorex & Tehnician Metrorex & Universitar (licen ă) & 12 clase \\
\hline 13 & Lucian & Lăcătuş & Croitoreasă & 10 clase & 10 clase \\
\hline 14 & Ciprian & Absent & Femeie de serviciu & - & 10 clase \\
\hline
\end{tabular}

Datele anonimizate, transcrise şi centralizate au fost supuse unei analize în două etape. În prima etapă, s-a derulat o analiză tematică de tip groundedtheory (Corbin \& Strauss, 2008) - principalele teme identificate în această etapă au împrumutat din limbajul colectivului studiat. A doua etapă a presupus interpretarea temelor într-o cheie critică (Anderson, 1989). Rezultatele cercetării sunt prezentate într-un registru subiectiv şi narativ, în semn de recunoaştere a calită ii lor interpretative (Atkinson \& Hammersley, 2007) şi în încercarea de a reprezenta chiar tensiunile şi complexitatea spa iului social studiat (Lincoln, Lynham \& Guba, 2018). În plus, textul este bogat în fragmente de conversa ie şi noti e de teren asupra cărora cititorul este invitat să propună propriile interpretări (Stake, 2005). 
În vederea colectării datelor, s-a ob inut consim ământul informat al tuturor celor implica i, respectându-se politica de etică a Universită ii din Bucureşti. Dintre persoanele abordate, 2 băie i au refuzat participarea la studiul de caz, chiar dacă părin ii lor au fost de acord. Numele tuturor subiec ilor au fost înlocuite cu pseudonime, pentru protec ia identită ii acestora.

\section{Rezultatele cercetării}

3.1. Dezinteresul, o idee comună elevilor şi profesorilor

La finalul primei zilei de observare, la intrarea în sala profesorilor am fost întrebată „Cum au fost? Cumin i? Le-am spus să nu se prefacă, să fie aşa cum sunt de obicei: obraznici!". Această descriere a elevilor de la clasa a VIII-a C îmi era deja familiară, o auzisem de la profesorii pe care îi întâlnisem până la momentul respectiv, eram eu însămi obosită de zgomotul, mişcarea din timpul orelor şi urma să fie confirmată de reflec iile elevilor intervieva i. Profesorii şi elevii folosesc caracterizarea „obraznici” pentru a descrie situa iile, mai ales din timpul orelor, când elevii vorbesc cu colegii, exprimă impresii şi emo ii într-o manieră disruptivă, nu răspund la întrebări, nu urmăresc vizual profesorul sau colegul care răspunde, nu iau noti e, nu respectă sarcina primită, fredonează muzică, foşnesc haine şi caiete, ticăie pixuri, bâ âie din picior, gesticulează, mănâncă, butonează telefonul.

Cea de-a doua idee larg împărtăşită despre clasa a VIII-a C este că elevii sunt ,dezinteresa i”. Profesoara de matematică previzionează că la evaluarea na ională aproape jumătate vor lua note de 6,7 sau 8 , iar un sfert (4 elevi) nu vor promova. Profesorii de chimie şi limba română sunt de aceeaşi părere, iar principala lor explica ie este faptul că elevii nu depun efortul necesar succesului şcolar. Datele colectate arată că elevii întăresc imaginea de „dezinteresa i” când nu ridică mâna, nu se oferă să lucreze la tablă, nu scriu după dictare, nu rezolvă temele primite, nu memorează informa iile cerute, nu se pregătesc suplimentar pentru evaluarea na ională şi/sau lipsesc de la ore.

„Ce aş putea să- i spun despre ei? Sunt dezinteresa $i$, uite, Alexandra, cu mintea ei, ar putea să ia numai note de 9 şi 10, dar, pentru că $e$ dezinteresată, ia numai note de 4 şi 5." (Profesor, Chimie) 
Eşecul anticipat la evaluarea na ională nu este o surpriză pentru cadrele didactice, ci le confirmă aşteptările formate în baza originii sociale a elevilor. Însă, profesoara de limba şi literatura română este preocupată de cum se vor reflecta rezultatele la evaluarea na ională asupra şcolii, iar cea de matematică simte că nu-şi poate îndeplini misiunea de a pregăti elevi cu poten ial pentru a fi admişi la licee apreciate. Totodată, profesorii se împacă cu insuccesul şcolar al elevilor spunându-şi că indiferent de rezultatele ob inute, aceştia pot şi vor să-şi continue studiile pe ruta profesională:

„Legat de aspira ii, ce să spun, majoritatea îşi ştiu măsura [şi îmi arată cu mâna că prin măsură se referă la nivelul de jos], din câte am vorbit cu ei, vor merge la şcoli profesionale, la licee tehnice, pe profilul profesional.” Pentru a-mi explica mai bine ce vrea să spună, profesorul imi povesteşte despre o feti $\breve{a}$ dintr-o altă clasă, la acelaşi nivel cu elevii din „C”, ai căror părin $i$, in clasa a V-a, $i$-au spus că vor să $o$ ducă la liceu. Profesorul îmi dă de în eles că a fost surprins, dar nu le-a spus nimic. Însă, în clasa a VIII-a, părin ii au revenit la el şi i-au spus că feti a va merge „la bucătari”. Profesorul mi-a explicat uşurat că părin ii au conştientizat ceea ce el ştia deja, apoi mi-a povestit despre fra ii fetei care au avut succes ca ,frizeri”, ,le-a mers bine”. Aspira iile din clasa a V-a le-a pus pe seama dorin ei părin ilor ,„ă meargă şi cineva din familia lor la liceu." (Profesor, Chimie)

„Ca ştiin ă, ei primesc, aici, la şcoală tot... Copiii mai buni pleacă de aici, în clasa a V-a, aşa ne spun învă ătoarele. Îi pierdem pe cei pe care i-am putea propulsa...Nu avem rezultate pe municipiu sau ară. În ziua de azi, pentru olimpiadă, trebuie pregătire specială. Nu putem fi to i de olimpiadă. Până la urmă, scopul nostru este să avem copii la licee de top. Unii ajung." (Profesor, Matematică)

„Majoritatea doresc să înve e o meserie, să meargă la profesională. Cei care înva ă mai bine, au aspira ii mai înalte. E normal, nu trebuie să fim to i doctori, e firesc, e nevoie şi de instalatori." (Profesor, Matematică)

Asemeni profesorilor lor, elevii se auto-descriu ca „leneşi” pentru că nu ridică mâna, nu îşi fac temele, nu citesc lec ia pentru a doua zi. Însă, în imaginarul acestora, aşteptările profesorilor privind procesul de predareînvă are-evaluare se suprapun cu cele legate de disciplină, după cum se 
poate vedea în răspunsul lui Dan şi al Alexandrei:

,[...] ca noi să ştim toate lucrurile care ni se predau, să luăm note din ce în ce mai mari, să fim aten i la ore, să nu mai vorbim sau să facem alte chestii şi cam atât, nu îmi mai vin idei ..." (Dan)

,[...] să fim foarte serioşi în privin a materiei pe care o predau, adică să ne vadă că ne facem temele non-stop, că învă ăm lec ie de lec ie, că stăm cu mâinile ridicate, că ne dăm interesu'... da, atâta timp cât avem mâna ridicată, văd interesu' nostru pentru materia lor...” (Alexandra)

Întrebat cum ar putea şcoala să-1 sprijine mai mult, Alin a răspuns scurt: „Şcoala e ok, noi avem o problemă, nu învă ăm!”. Acest răspuns este reprezentativ pentru modul în care s-au derulat toate interviurile cu elevii. Aceştia au condus discu iile înspre ideea că ei nu răspund aşteptărilor profesorilor, plasând responsabilitatea, în primul rând, pe ei înşişi. De asemenea, cu excep ia a 3 dintre ei, elevii intervieva i nu formulează aşteptări fa ă de profesori, decât implicit sau la stăruin a cercetătorului şi îşi reprezintă celelalte nevoi individuale ca o digresiune fa ă de şcoală. Pentru a ilustra această observa ie, vor fi descrise în detaliu 3 micro-cazuri: Nicolae, Geanina şi Marius. Ideile celor 3 elevi sunt reprezentative pentru restul datelor colectate, reflec iile lor ilustrează atât ideile comune ale elevilor despre învă are, cât şi diferen ele în ceea ce priveşte formularea propriilor aşteptări fa ă de profesori.

\subsection{Nicolae, Geanina şi Marius ... despre dezinteres în nuan e}

Nicolae nu a fost prezent la primele 2 ore de observare, iar absen a lui nu a fost primită cu surprindere din partea colegilor şi profesorilor. Ajuns la şcoală, s-a aşezat singur, în banca a doua de la perete şi s-a remarcat imediat prin întrebările şi observa iile adresate tuturor, în legătură sau nu cu subiectul lec iei. Nicolae e unul dintre elevii căruia i se dau cele mai mici şanse să ob ină o notă de trecere la evaluarea na ională şi are cel mai mare număr de absen e din clasă.

Părin ii lui Nicolae sunt surdo-mu i şi lucrează la METROREX, mama sa a terminat liceul, iar tatăl lui studii superioare. Despre ei, Nicolae spune că îl îndeamnă să aspire mai sus decât au putut ei ajunge, nu se interesează de 
note, dar în fiecare zi îl întreabă dacă a fost la şcoală. Nicolae e convins că trebuie să termine 12 clase pentru a ob ine un loc de muncă bine plătit, vrea să-şi continue studiile în învă ământul profesional-dual, iar în viitorul îndepărtat speră să lucreze ca vânzător.

În mod obişnuit, în timpul orelor sau după şcoală, Nicolae petrece timp în aer liber, îi place să joace baschet, handbal şi să stea cu prietenii în parc. Despre grupul de prieteni din parc povesteşte că sunt familia lui, se simte în eles şi liber să împărtăşească ceea ce trăieşte.

Şcoala, echivalată cu ,teoria”, ,învă area”, ,matematica”, e ceva greu de fixat într-un cuvânt, iar învă area este asociată de Nicolae cu în elegerea şi demonstrarea cunoaşterii. El se delimitează de şcoală şi atribuie responsabilitatea eşecului, în primul rând, sieşi, nu profesorului. Nicolae îşi justifică op iunea pentru învă ământul profesional-dual explicând că este mai potrivit pentru muncă (practică), decât pentru teorie, iar pentru a motiva absen a de la orele suplimentare de matematică, el foloseşte acelaşi argument şi îşi dezînvinovă eşte profesoara.

În aceeaşi logică, a asumării responsabilită ii, Nicolae sus ine că aten ia este precondi ia învă ării. De asemenea, el recunoaşte şi regretă că nu e suficient de atent la ore, dar nu-şi poate încă explica de ce:

Nicolae: Oricum, scopul învă ării e aten ia, adică dacă eşti atent, prinzi, dacă $n u, n u$, pe mai scurt, să spun aşa, am observat, gen, că când nu dau deloc aten ie orei, mă întreb de ce nu ştiu şi când dau aten ie, mă prind mult mai uşor şi ştiu cum să răspund la anumite chestii...

C: Ok... atunci câtă aten ie dai orelor?

Nicolae: De obicei dau 60/40, adică dau mai multă aten ie...Am unele momente când nu dau, când vreau să vorbesc, să comunic decât, nu dau aten ie orei chiar dacă e mai importantă ora decât ce fac eu... şi primesc aten ii pentru chestii de genul, eu tot continui săfac asta, nu ştiu, vorbesc, acasă nu prea vorbesc... în general, cu ai mei... şi simt nevoia asta, de comunicare, nu de altceva...

La fel, despre experien a repeten iei, Nicolae povesteşte cu împăcare, însă nu poate să-şi explice comportamentul său din perioada respectivă:

Nicolae: Păi chiuleam cam mult [clasa a VI-a], aveam un grup al meu, 
în clasa cu care chiuleam, gen, plecam de la ore, veneam când voiam... şii... aaa şi râdeam în ore, făceam o grămadă de chestii, supăram profesorii, gen, în exces, adică exageram foarte mult, to $i$ şi nu băgam de seamă. Când am aflat că am rămas, oricum, ştiam că o să rămân, şii... sincer, am plâns prima oară, că, gen, mi-a părut rău că am pierdut un an degeaba, şi pe urmă m-am gandit, bă, totuşi, mi-a plăcut, m-am distrat, nu neg faptul că am fost rău şi de atunci m-am schimbat... bine, încă, mai chiulesc, dar, totuşi, m-am schimbat... şi am rămas vreo 10 copii din clasă.

[...]

C: De ce te comportai aşa?

Nicolae: $\mathrm{Nu}$ ştiu, nu aveam un motiv anume sau ceva, doar, pur şi simplu, aşa mă comportam.

$\mathrm{C}$ : De ce te-ai schimbat?

Nicolae: Pentru că am conştientizat că, băi, uite, gen, vorbeam cu mine însămi, băi, Nicolae, uite, nu-i bine ce faci, încearcă şi tu, uşor, uşor, să te schimbi, o să vezi că e mai bine aşa.

În opozi ie cu modul în care se prezintă, ca neadecvat pentru şcoală, răspunsurile lui Nicolae dezvăluie observa ii fine despre ceea ce ar putea să-i sprijine învă area. Profesorul de referin ă pentru Nicolae este profesoara de limba română din clasa a VI-a, fa ă de care se sim ea în siguran ă să ceară ajutorul şi care explica pe în elesul tuturor, în repetate rânduri:

Nicolae: Gen, am avut noi o profesoara acum 2 ani, gen, 3, gen, ne explica super ok, gen, nu ne ascundeam când nu ştiam la ea, dacă nu ştiam zicea: mă bucur că mi-ai spus ca să mai repet încă o dată pentru toată lumea, gen, stătea să ne explice până în elegea toată lumea, chiar şi cel mai nepregătit din clasă în elegea...

C: Şi veneai la ore?

Nicolae: Da, cu mare drag, la română, veneam la ore.

$\mathrm{C}$ : Pe bune?

Dragoş: Da, to $i$ veneam la ore... şi ne bucuram to $i$ că veneam la ore, când ne spunea să tăcem, nu mai scoteam un sunet, nimic [...] Nicolae: Când a venit într-a şaptea, o nouă profesoară, nu ştiu din ce motiv s-a enervat, da, că nu ne făcusem tema şi ... ce? ce nu vă convine? este ceva în neregulă cu stilul meu de predare? şi în momentul acela am început să plâng, gen, nu sunt eu o fire mai sensibilă, dar când e ceva, 
care mi-a plăcut foarte mult şi a plecat, mă simt foarte prost, gen, că am pus suflet în chestia aia şi gen, am zis, în timp ce plângeam: Nu doamna, nu este vina dumneavoastră, însă mie unul, nu ştiu dacă le e şi lor, ne-am acomodat foarte mult cu stilul dânsei de predare şi felul ei, ca să zic aşa, gen, cred că ne va lua pu in timp până să ne acomodăm cu dvs. ...

De asemenea, Nicolae este revoltat fa ă de colegi, pentru că, întreba i de profesori dacă au în eles explica iile primite, elevii răspund afirmativ, chiar dacă o parte dintre ei, asemeni lui, nu au în eles. În ciuda indignării, Nicolae adoptă acelaşi comportament, pentru că experien ele anterioare 1-au învă at că exprimarea nevoilor poate să atragă dezaprobarea profesorilor:

Nicolae: $\mathrm{Cu}$ profesorul nu am nimica personal ca să zic aşa, dar, gen, predă în modul ăla, clasic şi neîn eles, ca să zic aşa, gen, zice 2 chestii, 3 , la tablă şi întreabă $a$ i în eles şi toată lumea zice $d a$ şi chiar dacă nu au în eles, tot da zice, chiar dacă nu, nu în eleg de ce...

$\mathrm{C}$ : Tu spui $d a$ ?

Nicolae: Da, ca să nu mai repete, că după, poate are o pasă proastă şi nu vrea să repete...

C: Ce înseamnă nu ai în eles?

Nicolae: Gen, nu m-am prins, chiar dacă dau aten ie, nu m-am prins... să zicem la română [...] mai întreb încă o dată, ca să fiu sigur, dacă e corect sau nu, în special, şi îmi zic că $n u$, face doamna o fa ă, îşi dă ochii peste cap şi cred că în mintea ei e ceva de genul: Bă copile, ce nu în elegi, am explicat?

C: Da, bun, am în eles că a i explicat, dar, totuşi, nu e pe modul ăla, băbeşte, să zică cuvânt cu cuvânt, aşa e mult mai uşor de re inut...

Geanina stă în prima bancă, profesorii nu vorbesc despre ea şi numele ei se aude rar în clasă. Tatăl Geaninei este zugrav, iar mama sa are 2 locuri de muncă, noaptea lucrează ca spălătoreasă la un hotel, iar ziua ca femeie de serviciu, ambii au terminat 8 clase. Despre părin ii săi, Geanina povesteşte că se aşteaptă de la ea să vină la şcoală şi să ob ină medii de trecere, iar când se abate de la aceste aşteptări, o pedepsesc prin restric ionarea accesului la telefon sau calculator.

Geanina îşi doreşte să devină manichiuristă, nu ştie dacă şi unde îşi poate continua studiile, dar crede că educa ia este importantă pentru a avea acces 
la un viitor loc de muncă. Din ceea ce înva ă la şcoală, crede că îi sunt utile abilită ile de scris-citit pentru că o ajută să se descurce la cumpărături şi prevede că îi vor fi de folos pentru a completa acte.

În mod obişnuit, după ore, Geanina are grijă de casă şi cei 3 fra i mai mici, se uită la seriale şi rareori îşi face temele. În ziua interviului urma să meargă acasă şi să facă o temă restantă la matematică, disciplina pentru care se pregăteşte cel mai des. Când se pregăteşte pentru a doua zi, motiva ia Geaninei este respectul fa ă de profesor sau teama de a nu fi umilită în fa a clasei:

„De multe ori, noi, când ne facem o temă, nu ne e frică mai mult de notă, ne e frică mai mult că ştim că se ipă la noi, aşa şi ne sim im prost, mai ales de fa ă cu to $i$ copiii ..."

Când vorbeşte despre timpul petrecut acasă, Geanina foloseşte metafora de „mamă”. Ea îngrijeşte casa şi 3 fra i mai mici, nu are resentimente fa ă de părin i şi e convinsă că trebuie să se descurce singură.

„Mama mea munceşte foarte mult, munceşte de noapte şi mai are încă un serviciu de diminea ă şi nu prea are când să vină, să doarmă... doarme vreo 3-4 ore pe zi... restul stă neîncetat trează, tatăl meu lucrează ziua particular, adică se duce, găseşte pe undeva să lucreze şi nu prea are când să stea de mine... şi în al doilea rând, trebuie să mă descurc singură."

Când vorbeşte despre ea ca elev, Geanina spune că o caracterizează lenea, se plasează în categoria celor despre care profesorii spun că pot, dar nu vor. Spre exemplu, în conversa ia redată mai jos se poate vedea cum Geanina şi Ionela au condus discu ia despre aşteptările profesorilor înspre faptul că ei, elevii, nu îndeplinesc aceste aşteptări, iar lenea reprezintă prima explica ie pe care ele o propun pentru asta. Însă, detaliile împărtăşite ulterior de Geanina dezvăluie faptul că ea nu are foarte mult timp şi energie să se pregătească pentru oră - ceea ce ini ial pare a fi timp pierdut cu seriale, reprezintă o pauză de 1-2 ore de la responsabilită ile de îngrijire ale familiei:

C: Ce aşteptări crede i că au profesorii de la voi?

Ionela: Să învă ăm...

C: Ce înseamnă să învă a i?

Ionela: Să ştim lec iile în afară de doar citit şi memorat, ca să ştim... ştiu că putem, dar nu facem. 
Geanina: La mine e vorba mai mult despre lene ...[...] lene, adică noiii... putem să facem lucruri, dar nu vrem.

C: Asta crede i voi sau asta vă spun ei?

Geanina: Deci, asta, de multe ori ne mai spune, când nu vrem să facem o temă sau nu vrem să facem un exerci iu... nu ştiu, spunem că nu ştim să facem un exerci iu şi ne spune... bă, voi şti $i$, dar nu vre $i$.

[...]

$\mathrm{C}:$ Au ei dreptate?

Geanina: Într-un fel, au dreptate.

[...]

Geanina: Adică noi suntem genul, vrem să ieşim afară, să stăm... să stăm degeaba, aşa, de exemplu, eu mă uit la televizor... eu sunt cu serialele mele indiene şi de multe ori eu stau şi prefer să mă uit la ele... sau de multe ori sunt obosită...

[...]

Geanina: Adică, cum e cu mine, că eu trebuie să fac cură enie, să stau de copii, să astea, de fra ii mei, dacă prind nişte pauze mici de 10-15 min aşa, între, după aia, stau un pic, mă apuc iarăşi, stau un pic, mă apuc iarăşi... nu am...

C: La seriale când te ui i?

Geanina: Am un serial de la ora 7, da, adică, câteodată mă uit la unul, câteodată... mai începe unul la 5 jumate şi se termină fix la 6 ... câteodată mă uit la ăsta sau la ăla.

[...]

C: Atunci când sunte i liberi, de ce nu face i ceva legat de şcoală?

Geanina: Păi dacă am făcut atâtea ore, în lucru, ce să mai fac, încă... de exemplu, da, adică, când prindem şi noi 10-15 minute aşa, să ne odihnim, pentru că stând să facem toate chestiile care avem noi ocupa iile cu ele, când prindem timpul ăsta liber, ne gândim, în loc să ne odihnim, că ştim că după, peste câteva minute o să începem iarăşi acelaşi lucru, stăm să facem altceva şi ne epuizăm şi mai tare...

Asemeni lui Nicolae, Geanina îşi asumă responsabilitatea pentru neîndeplinirea aşteptărilor profesorilor. Fără a revendica sprijin, Geanina remarcă profesorii care îi facilitează învă area. În ce o priveşte pe profesoara de istorie pe care o are în prezent, apreciază faptul că explică folosind cuvinte accesibile, pe profesorul de chimie îl place pentru că explică lent. Profesoara 
ei preferată este cea de limba română din clasa a VI-a, pentru că explica într-o manieră accesibilă ei, avea aşteptări abordabile şi crea o atmosferă plăcută la clasă:

Geanina: E cam dificil să schimbi profesori pentru că fiecare are altă atitudine de a preda, învă a şi e mai dificil, aşa... nouă ne-a plăcut foarte mult de o profesoară de română, doamna C., era, ce, mi-a... a plecat din cauză că s-a pensionat şi noi am prins-o decât un an [...] ne preda aşa... într-un mod ca să în elegem, era, prin glume, făcea rime cu chestiile astea ...era atât de amuzantă şi calmă [...] ea era foarte în elegătoare cu noi, nu îi plăcea un lucru, când ne dădea... ne dădea teme foarte pu ine, alea 2-3 exerci ii pe care ni le dădea trebuia să le facem, aşa, cum o fi fost, greşite, cum erau ele, trebuia să le facem pentru că se sim ea prost, adică ea face atâtea pentru noi şi noi, un lucru mărunt nu putem să-1 facem... şi eu am luat notă mare la ea, 7-8... de obicei eu iau 5 la română.

Marius este un elev despre care profesorii spun că este diferit de ceilal i şi că ,s-a pierdut" rămânând în acest colectiv. El însuşi a meditat asupra ideii de a se transfera, s-a întâmplat la trecerea în clasa a V-a şi avea în vedere o şcoală pe care o considera mai bună, dar a avut îndoieli despre capacitatea lui de a se integra în noul colectiv şi a decis să rămână. Marius se prezintă ca o persoană independentă, inclusiv în rela ie cu părin ii săi şi care respectă independen a celorlal i.

Mama lui Marius gestionează propria firmă de mentenan ă şi între inere a lifturilor, iar tatăl său vitreg este şofer, ambii au absolvit 12 clase şi examenul de bacalaureat. Marius spune că niciunul dintre părin i nu insistă asupra lui în ceea ce priveşte reuşita sa şcolară sau pentru a face anumite alegeri şi sunt mul umi i că are rezultate bune. Pe viitor, Marius vrea să fie admis la un liceu ,destul de bun”, la filologie, apoi, inspirat de un avocat pe care 1-a întâlnit când unchiul său a fost arestat, şi-ar dori să studieze dreptul.

În mod obişnuit, după şcoală, Marius petrece timp cu prietenii, în special cu o vecină care are o problemă la un picior, se uită 2-3 ore la seriale, participă la medita ii, îşi face temele şi îşi citeşte noti ele. Şcoala, prin notele şi aprecierea profesorului, reprezintă pentru Marius o sursă foarte importantă de validare. El justifică timpul petrecut pentru pregătirea orelor povestind despre satisfac ia pe care o are când ob ine o notă bună sau e lăudat de profesori: 
C: Dacă ai a doua zi un test, ce faci?

Marius: Păi mă pregătesc pentru test... îmi place să iau note mari, mă simt... mă simt bine în pielea mea când iau note mari...

C: Aşa a fost dintotdeauna?

Marius: Da, de când sunt mic [...] gen, mă sim eam bine când eram lăudat de către profesori şi chestii din astea... şi am început să continui...

Asemeni tuturor elevilor intervieva i, Marius îi apreciază pe unii profesori mai mult decât pe al ii, iar preferata lui este tot profesoara de limba şi literatura română din clasa a VI-a. Însă, spre deosebire de colegii lui, el îşi exprimă opiniile cu o mai mare lejeritate, mai nuan at şi le formulează în rela ie cu nevoile sale. Spre exemplu, Marius justifică medita iile la matematică explicând că are nevoie de mai mult timp şi explica ii personalizate pentru a re ine formulele matematice şi a în elege rezolvarea exerci iilor:

C: Tu mergi la pregătire la matematică şi română?

E: Merg mar ea la română, la pregătire, gen la şcoală şi la mate, nu, pentru că am meditator, fac medita ii.

C: De ce preferi meditatorul în locul pregătirii de la şcoală?

E: Chiar nu ştiu, pur şi simplu simt că am nevoie de mai mult timp alocat matematicii decât o oră ca să pot să în eleg mai bine exerci iile, să învă formulele matematice şi chestii.

\section{Concluzii}

Studiul de caz a dezvăluit că „obraznici” şi ,dezinteresa i” reprezintă două caracteristici recurente în reprezentările profesorilor despre elevii din clasa a VIII-a C, dar şi în auto-reprezentările acestora din urmă. Profesorii sus in că elevii nu se conformează normelor de disciplină şi nu înva ă suficient, iar cei din urmă confirmă şi întăresc aceste idei. Însă, analizate în profunzime, preocupările elevilor dezvăluie că aceştia încearcă să reconcilieze aşteptările profesorilor fa ă de ei cu diverse nevoi individuale.

Elevii au în comun convingerea că şcoala este importantă pentru ob inerea unui loc de muncă bine plătit, iar succesul şcolar le-ar aduce recunoaşterea părin ilor, profesorilor şi a colegilor. De asemenea, elevii cunosc aşteptările 
profesorilor: să fie urmări i vizual, să ridice mâna, să dea răspunsuri corecte, să rezolve sarcinile primite în clasă sau pentru acasă. În acelaşi timp, însă, elevii au adus în discu ie şi nevoia de comunicare şi recunoaştere, de timp pentru îngrijirea familiei şi de odihnă, de socializare şi relaxare. După cum se poate constata în cazurile lui Marius, Nicolae şi al Geaninei, în eforturile lor de reconciliere, balan a înclină, mai mult sau mai pu in, în favoarea şcolii. Totodată, elevi precum unii dintre cei intervieva i, care nu îndeplinesc aşteptările profesorilor, se prezintă ca neadecva i pentru şcoală, nu îşi pot explica propriul comportament şi îşi recunosc cu dificultate sau deloc alte nevoi individuale (de exemplu, de odihnă).

După cum este ilustrat prin răspunsurile lui Marius, Nicolae şi ale Geaninei, în imaginarul elevilor, învă area este echivalentă cu a în elege, a face temele, a memora anumite informa ii şi a răspunde corect, cel mai important pentru aceştia fiind să în eleagă explica iile profesorilor. „Doamna” de limba şi literatura română din clasa a VI-a este prezentată ca profesorul ideal pentru că le oferea explica ii repetate, într-un limbaj accesibil, le recunoştea meritele şi le dădea teme abordabile. Totodată, în ciuda rezisten ei pe care o manifestă la ore şi independen ei cu care se identifică, cu câteva excep ii, elevii nu vorbesc despre nevoile lor de sprijin în învă are, decât într-un mod implicit, ca atunci când descriu profesorii lor prefera i sau la stăruin a cercetătorului. Astfel, în cazul studiat, elevii cu status socio-economic scăzut par să îşi însuşească discursul deficitar al profesorilor, să îşi plaseze nevoile individuale, inclusiv cele de sprijin al învă ării, într-o zonă de ilegitimitate şi să reducă învă area la dimensiunea ei individuală. Elevii opun rezisten ă la ore, dar reprezentările lor despre învă are nu contestă autoritatea pedagogică, ci dezvăluie eforturile acestora de auto-disciplinare. În cazul studiat, se confirmă poten ialul de inculcare şi excluziune al ac iunii pedagogice (Bourdieu \& Passeron, 1978). Totodată, faptul că cei mai aprecia i elevi verbalizează nevoile lor de sprijin în învă are sugerează că însăşi clasa este un câmp de for e (Bourdieu, 1999), iar pozi ionarea elevilor fa ă de învă are este modelată şi de statutul dobândit de elevi în colectiv.

\section{Referin e}

- Anderson, G.L. (1989). Critical Ethnography in Education: Origins, Current Status, and New Directions. Review of Educational Research, 59(3), 249-270. 
https://doi.org/10.3102/00346543059003249

- Atkinson, P., \& Hammersley, M. (2007). Ethnography: Principles in Practice (3rd ed.). Routledge.

- Bernstein, B. (1978). Teoria codurilor şi şcoala. In F. Mahler (Ed.), Sociologia educa iei şi învă ământului. Antologie de texte contemporane de peste hotare (pp. 187-207). EDP.

- Botezat, A. (2019). Factori determinan i ai analfabetismului func ional. O analiză a datelor PISA pentru România. In G. Bădescu (Ed.), Şcoala din România din perspectiva datelor PISA (ed. I, pp. 125-158). Editura Presa Universitară Clujeană.

- Bourdieu, P. (1999). Ra iuni practice: o teorie a ac iunii. Meridiane.

- Bourdieu, P., \& Passeron, J. C. (1978). Pentru o teorie a violenpei simbolice. In F. Mahler (Ed.), Sociologia educa iei şi învă ământului. Antologie de texte contemporane de peste hotare (pp. 89-97). EDP.

- Calarco, J. M. (2011). 'I Need Help!' Social Class and Children's Help-Seeking in Elementary School. American Sociological Review, 76(6), 862-882. https://doi.org/10.1177/0003122411427177

- Coleman, J. S. (1966). Equality of Educational Opportunity. U.S. Dept. of Health, Education, and Welfare, Office of Education.

- Corbin, J., \& Strauss, A. (2008). Basics of Qualitative Research: Techniques and Procedures for Developing Grounded Theory (3rd ed.). Sage Publication.

- Creswell, J. W. (2014). Research design: qualitative, quantitative, and mixed methods approaches (4th ed.). Sage.

- Devine, D., \& McGillicuddy, D. (2016). Positioning pedagogy—a matter of children's rights. Oxford Review of Education, 42(4), 424-443.

https://doi.org/10.1080/03054985.2016.1197111

- Dunne M., \& Gazeley, L. (2008). Teachers, social class and underachievement. British Journal of Sociology of Education, 29(5), 451- 463.

https://doi.org/10.1080/01425690802263627

- Feşnic, F. (2019). Determinan i ai succesului la testul PISA 2015. In G. Bădescu (Ed.), Şcoala din România din perspectiva datelor PISA (ed. I, pp. 159-177). Editura Presa Universitară Clujeană.

- Freie, C. (2014). Average American teenager? White working-class high school students navigate race, privilege and opportunity. Social Identities, 20(2-3), 123-138. https://doi.org/10.1080/13504630.2014.881280

- Holland, D., Lachicotte, W., Skinner, D., \& Cain, C. (1998). Identity and agency in cultural worlds. Harvard University Press.

- Ivan, C. (2019). Interpretând studiul PISA 2015. In G. Bădescu (Ed.), Şcoala din România din perspectiva datelor PISA (ed. I, pp. 83-124). Editura Presa Universitară Clujeană.

- Jecan, D., \& Pop, C. (2012). Education and occupation for five generations in 
Romania: a sequential analysis of cohort status consistency. Studia UBB Socologica, 57(1), 61-81.

- Khan, S. R. (2011). Privilege: The Making of an Adolescent Elite at St. Paul's School. Princeton University Press.

- Lareau, A. (2011). Unequal Childhoods. Class, Race, and Family Life. University of California Press.

- Lincoln, Y. S., Lynham, S.A., \& Guba, E. G. (2018). Paradigmatic controversies, contradictions, and emerging confluences, revisited. In N. K. Denzin \& Y. S. Lincoln (Eds.), The SAGE handbook of qualitative research (5th ed., pp. 213263). Sage.

- Lupton, R., \& Hempel-Jorgensen, A. (2012). The importance of teaching: Pedagogical constraints and possibilities in working-class schools. Journal of Education Policy, 27(5), 601-620.

https://doi.org/10.1080/02680939.2012.710016

- Parker-Jenkins, M. (2016). Problematising ethnography and case study: reflections on using ethnographic techniques and researcher positioning. Ethnography and Education, 13(1), 18-33. https://doi.org/10.1080/17457823.2016.1253028

- Reay, D. (2001). Finding or losing yourself?: Working-class relationships to education. Journal of Education Policy, 16(4), 333-346.

https://doi.org/10.1080/02680930110054335

- Small, M. L. (2009). "How many cases do I need?": On science and the logic of case selection in field-based research. Ethnography, 10(1), 5-38. https://doi.org/10.1177/1466138108099586

- Stahl, G. (2016). White working-class male narratives of 'loyalty to self' in discourses of aspiration. British Journal of Sociology of Education, 37(5), 663-683. https://doi.org/10.1080/01425692.2014.982859

- Stake, R. (2005). Qualitative Case Studies. In N. K. Denzin \& Y. S. Lincoln (Eds.), The SAGE Handbook of Qualitative Research (pp. 443-466). SAGE.

- Tufiş, P. A. (2008). Predictors of school success in Romania. Family background, school factors, and community factor. Calitatea Vie ii, 19(3-4), 389-405.

- oc, S. (2016). Familie, şcoală şi succes şcolar în învă ământul liceal românesc. Calitatea Vie ii, 27(3), 189-215.

- Varly, P., Iosifescu, C.Ş., Fartuşnic, C., Andrei, T., \& Her eliu, C. (2014). Costul investi iei insuficiente în educa ie în România. UNICEF.

- Wenger, E. (1998). Communities of practice: Learning, meaning, and identity. Cambridge University Press. 
The online version of this article can be found at: http://revped.ise.ro/category/2020-en/

\section{(CC) $\mathbb{B Y - N C - S A}$}

This work is licensed under the Creative Commons Attribution-NonCommercial-ShareAlike 4.0 International License.

To view a copy of this license, visit http://creativecommons.org/licenses/by-nc-sa/4.0/ or send a letter to Creative Commons, PO Box 1866, Mountain View, CA 94042, USA.
Versiunea online a acestui articol poate fi găsită la: http://revped.ise.ro/category/2020-ro/

\section{(cC) DY-NC-SA}

Această lucrare este licen iată sub Creative Commons Attribution-NonCommercial-ShareAlike 4.0 International License.

Pentru a vedea o copie a acestei licen e, vizita $i$ http://creativecommons.org/licenses/by-nc-sa/4.0/ sau trimite i o scrisoare către Creative Commons, PO Box 1866, Mountain View, CA 94042, SUA. 


\title{
RESURSE SOCIALE ALE ŞCOLILOR DIN ZONELE DEFAVORIZATE
}

\author{
Aura abără* \\ Ovidiu Bunea**
}

\author{
Universitatea „Al. I. Cuza”, \\ Iaşi, România \\ iasiaura@yahoo.com \\ ovidiulbunea@gmail.com
}

\section{Rezumat}

Articolul prezintă concluziile unei cercetări desfăşurate în anul 2019 în jude ul Iaşi, cercetare care a urmărit descrierea şi măsurarea principalelor resurse sociale ale şcolii, aşa cum rezultă din opiniile cadrelor didactice. Demersul a urmărit identificarea punctelor tari şi a celor slabe, în vederea realizării unei diagnoze în unită ile avute în vedere. Cercetarea pe bază de chestionar s-a desfăşurat în şase unită i şcolare, trei din mediul urban şi trei din mediul rural, încadrate în categoria localită ilor defavorizate socio-economic. În şcolile implicate înva ă 5237 de copii, iar activitatea este coordonată de 345 de cadre didactice, din care au răspuns la chestionar 156. Instrumentul a fost construit prin opera ionalizarea conceptului de Şcoală Prietenoasă Copilului, concept promovat de UNICEF, prin intermediul a cinci indicatori: eficacitate, incluziune, încredere a copiilor în şcoală, siguran $\breve{a}$, rela ia cu părin ii. Media cea mai ridicată a fost ob inută de variabila ,încredere”, urmată de „eficacitate”; în a doua categorie se află ,incluziunea” şi „rela ia cu părin ii”, iar „siguran a” este pe ultimul loc. În ansamblu, a rezultat că responden ii cadre didactice au o părere bună în ceea ce priveşte încrederea pe care copiii o au în şcoală şi în îndeplinirea misiunii lor, dar evaluează critic rela ia cu părin ii şi siguran a din unită ile de învă ământ.

Cuvinte-cheie: eficacitate, incluziune, resurse sociale ale şcolii, Şcoală Prietenoasă Copilului.

* Doctorand, Facultatea de Filosofie şi Ştiin e Social-Politice, Universitatea „Al. I. Cuza”, Iaşi, România.

** Lector asociat, Facultatea de Filosofie şi Ştiin e Social-Politice, Universitatea „Al. I.Cuza”, Iaşi, România. 


\section{Abstract}

The article presents the conclusions of a research carried out in 2019 in Iassi County, aiming to describe and measure the main school social resources, based on the teachers' opinion. The research aimed to identify the strengths and weaknesses in order to perform a diagnosis of the schools considered. The questionnaire-based research was carried out in three urban schools and three rural schools located in socially and economically disadvantaged areas. A total of 5237 students attend the six schools involved, with 345 teachers employed, of whom 156 provided answers to the questionnaire. The instrument was built by operationalizing the concept of Child Friendly School, promoted by UNICEF, using five indicators: effectiveness, inclusion, children's trust in school, safety, relationship with parents. The highest score was achieved by the "children's trust in school" indicator, followed by "effectiveness"; in the second category, there are "inclusion" and "relationship with parents", while "safety" scored the lowest. Overall, it turned out that the respondent teachers have a good opinion regarding the confidence that the children have in school and in the accomplishment of their mission, but critically evaluate the schools' relationship with the parents and safety in schools.

Keywords: Child Friendly School, effectiveness, inclusion, school social resources.

\section{Introducere}

În lumea modernă, şcolile sunt nevoite să se schimbe, să demonstreze că sunt organiza ii sănătoase (Miles, 1967), care îşi dezvoltă permanent condi iile de şcolarizare (Hargreaves, 1995). Şcoala se transformă din organiza ie birocratică în organiza ie managerială (Cristea, 2008) şi se afirmă ca o institu ie deschisă, sensibilă la schimbările din mediul intern şi extern, dispusă să îşi asume riscuri şi idei noi, să înve e din propriile experien e şi să-şi asume responsabilitatea pentru propria dezvoltare şi eficien ă.

Problematica dezvoltării institu iei şcolare (Fullan, 2007; Hargreaves, 1998; Hopkins, 2004) este abordată ca răspuns la presiunea politicilor de reformă, ca modalitate de corelare a politicilor cu practicile educa ionale pentru a ob ine învă are eficientă la elevi, prin intermediul profesorilor eficien i. În ara noastră, politicile şi reformele implementate în educa ie după anii '90 s-au concentrat, cu precădere, pe necesitatea îmbunătă irii doar a anumitor resurse educa ionale (resurse materiale şi capital uman), ca o garan ie a creşterii calită ii educa iei şi a rezultatelor şcolare ale elevilor. Studii recente 
demonstrează faptul că este utilă o schimbare a viziunii, argumentând oportunitatea orientării şi către al i factori, aceia care in de resursele sociale ale şcolilor ( oc, 2016).

Problema pe care noi am identificat-o în spa iul educa ional preuniversitar românesc este aceea a absen ei unui instrument uşor de aplicat, descriptiv, care să măsoare resursele sociale ale şcolilor din perspectiva şcolii prietenoase copilului şi care să faciliteze interven ii pentru eficientizarea şcolilor ca institu ii de formare, centrate pe respectarea drepturilor copiilor. În viziunea noastră, este importantă evaluarea incluziunii şcolare, a rela iei scoală-familie, a nivelului de încredere a elevilor în şcoală şi profesori ca resurse sociale ale şcolii, fiind factori de calitatea cărora depinde eficien a scolară.

Men ionăm faptul că datele prezentate şi analizate în cadrul acestui articol au fost ob inute în cadrul proiectului ,Şcoli prietenoase în comunită $i$ implicate”, cofinan at din fonduri europene şi implementat de Inspectoratul Şcolar Jude ean Iaşi.

\section{Perspective teoretice}

2.1. Eficien ă şi resurse ale institu iei şcolare

O şcoală eficientă este o şcoală care se dezvoltă, care implementează schimbări de lungă durată, atât în ceea ce priveşte calitatea procesului instructiv-educativ, cât şi asupra condi iilor organiza ionale care sus in învă area. Dacă avem în vedere eficien a şcolară, aceasta reprezintă ,gradul de valorificare a resurselor pedagogice (informa ionale, umane, didactico-materiale, financiare) existente la nivel de sistem şi de proces, în cadrul organiza iei şcolare şi al clasei de elevi” (Cristea, 2008, p. 107). Considerăm că o şcoală eficientă asigură progresul şcolar pentru elevi, dacă reuşeşte să valorifice toate resursele de care dispune. Eficien a unei institu ii şcolare depinde şi de măsura în care dezvoltă rela ii de încredere cu beneficiarii direc i şi indirec i ai educa iei. Profesorii au nevoie să descopere în părin i un partener pentru dezvoltarea copiilor, dar şi părin ii au nevoie să simtă că ideile şi ini iativele lor sunt importante pentru deciziile care se iau la nivelul şcolii. Familia este 
considerată unul dintre cei mai importan i factori-predictori ai succesului şcolar (Coleman et al., 1966), alături de factorii ereditari (Jensen, 1969) şi de condi iile socio-economice (Bowles \& Gintis, 1976). Existen a unor rela ii de încredere între membrii organiza iei şcolare, implicarea familiei în via a şcolii şi colaborarea autentică cu părin ii copiilor reprezintă factori de care depind progresul şi succesul şcolar, eficien a şcolară. Pornind de la această abordare, considerăm că un prim pas în analiza eficien ei este inventarierea şi măsurarea resurselor sociale de care dispune şcoala.

Studiile empirice recente au demonstrat că există diferen e considerabile în ceea ce priveşte influen a familiei, în func ie de nivelul de dezvoltare a ărilor: în ările dezvoltate, studiile argumentează că influen a statutului socio-economic al familiei asupra succesului şcolar s-a diminuat (Breen et al., 2009, apud oc, 2016), în timp ce în ările sărace sau în curs de dezvoltare, familia pare să aibă un rol important în generarea de oportunită i educa ionale (Buchmann \& Hannum, 2001, apud oc, 2016; Gamoran \& Long, 2006).

Spre deosebire de resursele materiale sau umane care se referă la timp, bani şi abilită i individuale, ,resursele sociale şcolare constau în structura şi calitatea rela iilor dintre membrii personalului care oferă resurse pentru practica şi perfec ionarea instruirii" (Hanselman et al., 2016, p. 3). Deşi instruirea se desfăşoară de obicei în mod independent, legăturile puternice dintre angaja i îi determină să fie inovativi să îşi îmbunătă ească practica educa ională, rela iile şi resursele sociale dintre membrii personalului şcolar sunt recunoscute din ce în ce mai mult ca fiind, ,esen a activită ii într-o comunitate şcolară” (Bryk et al., 2010, p. 137).

România este o ară în care sărăcia reprezintă o problemă de amploare, ce influen ează educa ia, mare parte din şcoli desfăşurându-şi activitatea în zone defavorizate. Studiile realizate în ara noastră au demonstrat că specificul acestor comunită i induce elevilor atitudini de dezinteres fa ă de învă are (Tufiş, 2008). Totodată, în aceste zone, familia are o influen ă educa ională importantă, în sensul în care elevii care provin din familii cu resurse socio-economice şi culturale reduse ob in rezultate şcolare slabe (Hatos, 2019; oc, 2016). Aceste studii recomandă ,,ca şcolile să se întrebe ce al i factori în afară de cei individuali pot avea un efect asupra performan elor şcolare şi ascensiunii educa ionale a elevilor" ( oc, 2016, p. 23). În opinia noastră, 
concentrarea aten iei asupra incluziunii şcolare, a dezvoltării rela iei şcoală - familie şi a încrederii în şcoală şi actorii ei reprezintă astfel de factori.

\subsection{Modelul Şcolii Prietenoase Copilului}

Experien a a demonstrat că strategiile de dezvoltare institu ională implementate la ini iativa şcolilor sunt ineficiente, deoarece şcolile reac ionează în mod spontan şi necoordonat la provocările mediului extern (Hopkins, 2004). În acest context, au fost dezvoltate şi implementate numeroase programe având ca scop eficientizarea şcolilor.

Dintre acestea, aten ia noastră se concentrează pe modelul Şcolii Prietenoase Copilului (SPC), un model global pe care UNICEF îl promovează începând cu mijlocul anilor 1990 şi care plasează în centrul preocupărilor sale drepturile copiilor. SPC urmăreşte incluziunea, eficien a academică a curriculumului şi relevan a acestuia pentru via a de zi cu zi, realizarea unui mediu sigur, protector şi sănătos pentru starea de bine fizică şi psihică a copiilor, echitatea şi sensibilitatea în raport cu aspecte legate de gen, implicarea şi participarea activă a familiilor şi a comunită ii în via a şcolii. Modelul este unul de şcoală eficientă, aspect eviden iat de analiza comparativă a dimensiunilor specifice şcolii prietenoase şi a aspectelor ce caracterizează şcoala eficientă, conform datelor din Tabelul nr. 1.

Modelul a fost conceput pentru a fi implementat şi adaptat în ări din zone şi continente diferite, care se caracterizează prin contexte economice, sociale şi culturale variate (Godfrey et al., 2012), fiind, astfel, o abordare care se poate aplica fără rezerve sistemului de educa ie din România.

Din această perspectivă, am propus un instrument descriptiv, care să măsoare resursele sociale ale şcolilor din perspectiva SPC, instrument structurat pe următoarele dimensiuni:

- Incredere: se referă la perceperea şcolii de către copii ca fiind o resursă la care apelează, mai ales atunci când se confruntă cu dificultă i. Ei se simt confortabil în şcoală şi apelează la profesori şi învă ători în probleme legate de învă ătură şi/ori de ordin personal. Am optat pentru această 
dimensiune ca resursă socială a şcolii, deoarece încrederea este considerată în literatura de specialitate ca fiind un element esen ial pentru buna func ionare a organiza iilor (Seashore \& Lee, 2016, p. 539; Uline et al., 1998, p. 470).

- Protec ie şi siguran ă: are în vedere măsura în care copiii percep mediul şcolar ca fiind unul sigur, atât din punct de vedere fizic, cât şi psihic, un spa iu în care incidentele (violen e, abuzuri) au o frecven ă redusă şi afectează în mică măsură sentimentul de siguran ă a elevilor. $\mathrm{O}$ şcoală sigură reprezintă o organiza ie sănătoasă în care elevii se simt bine şi capabili să înve e şi să se dezvolte (Uline et al., 1998, p. 470).

Tabelul nr. 1. Analiza comparativă între caracteristicile şcolii eficiente şi dimensiunile SPC

\begin{tabular}{|c|c|c|}
\hline $\begin{array}{c}\text { Şcoală eficientă } \\
\text { (Kaplan \& Owings, 2013) }\end{array}$ & $\begin{array}{l}\text { Şcoala eficientă } \\
\text { (Finley, 2000) }\end{array}$ & $\begin{array}{c}\text { SPC } \\
\text { (UNICEF, 2012) }\end{array}$ \\
\hline Leadership puternic & $\begin{array}{l}\text { Misiune clară } \\
\text { Leadership puternic }\end{array}$ & \\
\hline $\begin{array}{l}\text { Mediu de învă are sigur şi } \\
\text { stimulant }\end{array}$ & Mediu sigur, ordonat şi pozitiv & $\begin{array}{l}\text { Mediu sigur, protector şi sănătos } \\
\text { pentru starea de bine fizică şi psihică a } \\
\text { copiilor }\end{array}$ \\
\hline Rela ii puternice bazate pe & & Incluziune proactivă \\
\hline încredere şi valori etice & & $\begin{array}{l}\text { Echitate şi sensibilitate în raport cu } \\
\text { aspecte legate de gen }\end{array}$ \\
\hline $\begin{array}{l}\text { Capacitate profesională } \\
\text { crescută a profesorilor, de } \\
\text { instruire şi conducere }\end{array}$ & $\begin{array}{l}\text { Utilizarea la maximum a timpului de } \\
\text { instruire, de învă are }\end{array}$ & $\begin{array}{l}\text { Eficien a academică a } \\
\text { curriculumului şi relevan a acestuia } \\
\text { din punctul de vedere al dezvoltării }\end{array}$ \\
\hline Instruire centrată pe elev & $\begin{array}{l}\text { Practici educa ionale eficiente } \\
\text { Obiective, aşteptări înalte } \\
\text { Monitorizarea progresului elevilor }\end{array}$ & $\begin{array}{l}\text { competen elor cheie ale copiilor şi a } \\
\text { abilită ilor de via ă }\end{array}$ \\
\hline $\begin{array}{l}\text { Men inerea şi dezvoltarea } \\
\text { legăturii cu părin ii şi } \\
\text { comunitatea }\end{array}$ & Rela ii şcoală-familie pozitive & $\begin{array}{l}\text { Implicarea şi participarea activă a } \\
\text { familiilor şi a comunită ii în toate } \\
\text { aspectele ce in de via a şcolii }\end{array}$ \\
\hline
\end{tabular}

- Incluziune şi suport: exprimă capacitatea şcolii de a fi un sprijin pentru elevi, cu precădere pentru elevii vulnerabili (cu dizabilită i, săraci, afla i în măsuri de protec ie etc.). Şcoala modernă este acea institu ie care depune eforturi considerabile pentru a se adapta la nevoile elevilor, urmărind implicarea şi valorizarea tuturor copiilor, indiferent de etnie, statut social, dizabilitate, religie, gen etc. (UNICEF, 2012).

- Eficacitate: se referă la măsura în care se consideră că şcoala îşi atinge obiectivele ca institu ie de formare, reuşind să dezvolte la copii competen ele necesare integrării sociale şi profesionale ca viitori adul i. Rela iile interpersonale pozitive reprezintă o condi ie necesară pentru ca elevii să ob ină rezultate şcolare bune (Corwin \& Borman, 1998; Hoy 
et al., 1990). Predarea şi învă area au loc la nivelul clasei, în timp ce alte niveluri ale organiza iei oferă condi iile necesare pentru desfăşurarea acestor activită i (Uline et al., 1998).

- Implicarea şi suportul familiei: se referă la calitatea legăturii dintre şcoală şi părin i, la măsura în care familia este implicată în mod real în via a comunită ii şcolare. Parteneriatul şcoală-familie a fost îndelung abordat în cercetarea de specialitate, deopotrivă ca resursă pentru asigurarea respectării drepturilor copiilor şi ca premisă a eficien ei organiza iei şcolare.

Chestionarul se adresează cadrelor didactice, având în vedere calitatea lor de principali creatori ai culturii organiza ionale şi ai situa iilor de învă are, actori ai procesului educa ional, persoane autoreflexive şi interesate de dezvoltarea personală şi a institu iilor în care îşi desfăşoară activitatea. Pentru a răspunde la întrebările chestionarului, au fost situa ii în care profesorii au trebuit să se pună în locul elevilor lor; am optat pentru această modalitate de evaluare pentru a nu exclude din cercetare copiii de vârstă preşcolară şi elevii de vârste mici, care nu au o opinie formată asupra acestor probleme sau care nu ar reuşi să îşi exprime opinia pe care o au.

\section{Metodologie}

\subsection{Participan i}

Cercetarea s-a desfăşurat în şase şcoli din jude ul Iaşi, situate în medii defavorizate, trei din mediul urban şi trei din mediul rural. În unită ile de învă ământ selectate sunt înscrişi peste 5000 de copii, cu vârste cuprinse între 3 şi 19 ani, mare parte dintre ei fiind expuşi riscului de abandon şcolar. La cercetare au participat 156 de profesori, dintr-un total de 345 de cadre didactice care activează în cele şase şcoli. Date despre şcolile în care s-a desfăşurat cercetarea şi responden i sunt prezentate în Tabelul nr. 2.

Şcolile au fost selectate în func ie de clasa de defavorizare în care au fost încadrate de către Ministerul Educa iei Na ionale în Anexa nr. 1 la Ghidul solicitantului specific Programului ,Şcoală pentru to i”(2016), ghid elaborat în vederea implementării de proiecte finan ate din fonduri europene. Cele 
Tabelul nr. 2. Distribu ia responden ilor după unitatea de învă ământ

\begin{tabular}{lcccc}
\hline $\begin{array}{c}\text { Unitatea de } \\
\text { învă ământ în care s-a } \\
\text { realizat cercetarea }\end{array}$ & $\begin{array}{c}\text { Nr. cadre didatice } \\
\text { angajate }\end{array}$ & Nr. responden i & \% & Mediu (U/R) \\
\hline $\begin{array}{l}\text { Liceul Teoretic } \\
\text {,L. Rosetti” Răducăneni }\end{array}$ & 91 & 39 & 25 & $\mathrm{R}$ \\
$\begin{array}{l}\text { SScoala Gimnazială } \\
\text { „Al. I. Cuza” Podu Iloaiei }\end{array}$ & 80 & 32 & 20,5 & $\mathrm{U}$ \\
$\begin{array}{l}\text { Şcoala Gimnazială } \\
\text { „C. Erbiceanu” Erbiceni }\end{array}$ & 34 & 10 & 6,4 & $\mathrm{R}$ \\
$\begin{array}{l}\text { Şcoala Gimnazială } \\
\text { „Petru Rareş” Hârlău }\end{array}$ & 63 & 35 & 22,4 & $\mathrm{U}$ \\
$\begin{array}{l}\text { Şcoala Gimnazială Deleni } \\
\text { Şcoala Gimnazială }\end{array}$ & 51 & 26 & 16,7 & $\mathrm{R}$ \\
Pârcovaci & 26 & 5 & 3,2 & $\mathrm{U}$ \\
NR & - & 9 & 5,8 & \\
Total & $\mathbf{3 4 5}$ & $\mathbf{1 5 6}$ & $\mathbf{1 0 0}$ & \\
\hline
\end{tabular}

Sursa: http://scoli-prietenoase.ro/wp-content/uploads/2020/03/Raport-analiza_chestionareprofesori_preinterventie.pdf accesat pe 06.03.2020

şase unită i au fost încadrate în clasa 4 de defavorizare, din 6 clase posibile (clasa 6 - şcolile cele mai defavorizate). Cinci institu ii sunt şcoli gimnaziale şi una este liceu teoretic, care, însă, are în componen a sa toate nivelurile de învă ământ (preşcolar, primar, gimnazial şi liceal). Responden ii au fost în mare majoritate femei (118 - F; 22 - M; 16 - NR), reflectând structura personalului din învă ământul preuniversitar.

\subsection{Procedura}

Am elaborat un chestionar cu 35 de itemi sub forma unor scale Likert cu şase variante de răspuns, itemi care se referă la indicatori considera i de către noi esen iali pentru ceea ce înseamnă SPC: încrederea elevilor în şcoală (4 itemi), siguran aîn şcoală (4 iemi), incluziunea (6 itemi), eficacitatea (11 itemi) şi rela ia cadrelor didactice din şcoală cu membrii familiilor din care provin copiii (10 itemi). Chestionarul a fost completat în perioada martie - aprilie 2019, cu ajutorul mijloacelor electronice, acolo unde au existat adresele de e-mail ale responden ilor, şi în format creion-hârtie, acolo unde nu a fost posibilă distribuirea prin poşta electronică. În final, au fost centralizate 156 de chestionare, 123 de chestionare completate electronic şi 33 de chestionare completate în format printat. 


\subsection{Validitatea şi fidelitatea instrumentului}

Validitatea se referă la gradul în care o măsură empirică reflectă adecvat conceptul cercetat (Babbie, 2010). În elaborarea acestui instrument nu am avut în vedere un concept acoperitor al celor şase factori lua $i$ în considerare, scopul nostru fiind unul descriptiv. În aceste condi ii, nu vorbim despre validitatea unui anume concept, ci despre măsura în care factorii afla i aici în discu ie reflectă cu adevărat realitatea la care se referă. Pentru a ne asigura de validitatea de con inut a chestionarului, acesta a fost elaborat împreună cu profesori din şcoli identice celor în care el a fost aplicat, fiind discutate fiecare dimensiune şi item în parte; odată elaborat instrumentul, a fost pretestat pe un grup de 10 responden i, ale căror observa ii au fost valorificate. În ceea ce priveşte fidelitatea, aceasta este estimată prin intermediul coeficientului Cronbach $\alpha$, ale cărui valori, pentru fiecare factor luat în considerare, apar în Tabelul nr. 3.

Tabelul nr. 3. Valorile coeficientului Cronbach $\alpha$ pentru subscalele componente ale instrumentului

\begin{tabular}{lcc}
\hline \multicolumn{1}{c}{ Dimensiune } & $\begin{array}{c}\text { Valoarea coeficientului } \\
\text { Cronbach } \alpha\end{array}$ & Număr de itemi \\
\hline Încredere & 0,698 & 4 \\
Siguran ă şi protec ie & 0,549 & 4 \\
Incluziune şi suport & 0,434 & 6 \\
Eficacitate & 0,819 & 11 \\
Rela ia cu familia & 0,832 & 10 \\
Total instrument & 0,874 & 35 \\
\hline
\end{tabular}

Conform lui George şi Mallery (2003), valorile coeficientului Cronbach $\alpha$ au următoarea semnifica ie: $>0,9$ excelent; $0,9-0,8$ bun; $0,8-0,7$ acceptabil; $0,7-0,6$ discutabil; $0,6-0,5$ slab $;<0,5$ inacceptabil.

\section{Rezultate}

Prezentarea rezultatelor urmăreşte eviden ierea punctelor slabe şi a celor tari ale fiecărei şcoli în parte şi în func ie de mediu (urban sau rural). Acolo unde am considerat important, sunt prezentate şi mediile ob inute de fiecare 
item în parte, având în vedere faptul că fiecare oferă informa ii cu privire la contextul educa ional din şcolile avute în vedere.

\subsection{Dimensiunea Încredere}

Variabila, cu toate că se referă la copii, este măsurată indirect, prin intermediul percep iei cadrelor didactice care şi-au exprimat acordul/dezacordul cu privire la patru afirma ii (Tabelul nr. 4).

Valorile mediilor în func ie de mediul de func ionare a organiza iei sunt de 4.85 în urban şi de 4.96 în rural; valorile extreme pe localită ile în care func ionează şcolile se situează între 4.8 (Pârcovaci, urban) şi 5 (Deleni, mediul urban). Diferen a nu poate fi pusă pe seama mărimii şcolilor - care ar genera comportamente particulare - pentru că acestea sunt comparabile ca mărime (Tabelul nr. 2). Dat fiind acest lucru, poate rezulta, ca ipoteză, faptul că, în rural, cadrele didactice se bucură de mai mult respect - încrederea fiind un indicator al acesteia - fa ă de cele care func ionează la oraş.

Tabelul nr. 4. Itemii care compun variabila Încredere (procente)

\begin{tabular}{lcccccc}
\hline \multicolumn{1}{c}{ Item } & DT & D & DR & AR & A & AT \\
\hline $\begin{array}{l}\text { Copiii solicită ajutorul } \\
\text { profesorilor în rezolvarea } \\
\text { problemelor apărute la şcoală }\end{array}$ & - & 1,9 & 1,3 & 10,9 & 53,2 & 32,7 \\
$\begin{array}{l}\text { Elevii se implică cu plăcere } \\
\text { in activită ile zilnice propuse } \\
\text { de cadrele didactice }\end{array}$ & - & 0,6 & 1,3 & 21,8 & 56,4 & 19,9 \\
$\begin{array}{l}\text { Copiii se simt bine la şcoală } \\
\begin{array}{l}\text { Copiii apelează la ajutorul } \\
\text { cadrelor didactice în }\end{array}\end{array}$ & - & 1,3 & 0,6 & 11,5 & 62,2 & 23,7 \\
$\begin{array}{l}\text { rezolvarea dificultă ilor } \\
\text { personale şi familiale }\end{array}$ & - & 4,5 & 9,6 & 35,9 & 40,4 & 9,6 \\
\hline
\end{tabular}

(Notă: DT - dezacord total, D - dezacord, DR - dezacord redus, AR - acord redus, A - acord, $A T$ - acord total)

Sursa: https://scoli-prietenoase.ro/wp-content/uploads/2019/03/Raport-evaluare-profesoriADS_SDS.pdf, accesat pe 06.03.2020

Analiza detaliată în func ie de itemii componen i ai dimensiunii eviden iază faptul că elevii au încredere în şcoală în ceea ce priveşte rezolvarea problemelor educa ionale, se simt bine atunci când sunt la şcoală şi atunci când sunt provoca i să se implice în diverse activită i educa ionale (Tabelul nr. 4). 
Răspunsurile la fiecare dintre aceşti itemi au întrunit acord şi acord total în procent de peste $76 \%$. Doar $50 \%$ în ceea ce priveşte acordul şi acordul total este înregistrat de itemul care men ionează apelul la cadrele didactice în rezolvarea problemelor personale, de unde putem trage concluzia că încrederea se opreşte în bună măsură la poarta şcolii, cadrul didactic nefiind văzut ca un suport în rezolvarea eventualelor probleme personale şi/sau familiale.

\subsection{Dimensiunea Protec ie şi siguran $\breve{a}$}

Nivelul de siguran ă pe care-1 resimt copiii şi cadrele didactice în şcoli a fost măsurat prin intermediul a patru itemi; trei dintre aceştia descriu unele dintre cele mai importante incidente ce pot să apară în context şcolar: distrugeri de bunuri, agresiuni verbale sau fizice. În măsurarea acestor trei itemi am codificat invers răspunsurile, în sensul în care am acordat valoarea 6 unui dezacord total şi 1 unui acord total. Corespunzător, pentru aceşti itemi, cu cât valoarea mediei este mai mare, cu atât şcoala este mai nesigură, mai pu in prietenoasă.

În urma analizei răspunsurilor, rezultă că în şcolile din mediul urban incidentele nedorite sunt mai rare şi, astfel, unită ile pot fi considerate mai sigure (o valoare a mediei de 4.04) fa ă de cele din mediul rural (cu o medie de 3.84). Ne putem imagina faptul că şcolile din urban sunt mai sigure dispun de personal de pază, camere de luat vederi, măsuri mai categorice în privin a evitării incidentelor nedorite - dar asta nu le face neapărat mai prietenoase, mai apropiate de elev, conform variabilei încredere, de mai sus. Se desprind de aici două profiluri diferite ale şcolilor, în func ie de mediu: una mai formalizată la oraş şi o alta mai informală, mai apropiată de copil, dar în care se înregistrează mai multe evenimente negative, în rural.

\subsection{Dimensiunea Incluziune şi suport}

Deorece această scală nu a trecut testul consisten ei (Tabelul nr. 3), prezentăm procentele răspunsurilor fiecărui item în parte, pentru valoarea descriptivă a elementelor pe care le-am avut în vedere, fără a calcula media răspunsurilor.

Conform Tabelului nr. 5, cvasitotalitatea (98.7\%) cadrelor didactice care au răspuns la chestionar apreciază că activită ile educa ionale au în vedere 
cooperarea - şi nu competi ia - între elevi. De asemenea, aproape to $\mathrm{i}$ responden ii (89\%) consideră că şcoala se implică în ajutorarea elevilor atunci când se confruntă cu situa ii familiale/personale dificile, însă în ciuda acestui fapt, aşa cum a rezultat din răspunsurile la un item anterior (Tabelul nr. 4), institu ia nu este percepută ca suport pentru elevi în rezolvarea problemelor extraşcolare. Răspunsurile la itemii individuali pot fi analiza i în vederea unor eventuale interven ii, însă ei nu descriu o dimensiune particulară.

Tabelul nr. 5. Itemii care compun variabila Incluziune şi suport (procente)

\begin{tabular}{lcccccc}
\hline \multicolumn{1}{c}{ Item } & DT & $\boldsymbol{D}$ & $\boldsymbol{D R}$ & $\boldsymbol{A R}$ & $\boldsymbol{A}$ & $\boldsymbol{A T}$ \\
\hline $\begin{array}{l}\text { Copiii se implică cu entuziasm în activită ile } \\
\text { ini iate de şcoală }\end{array}$ & 3,2 & 4,5 & 2,6 & 16,7 & 47,4 & 25,6 \\
\hline $\begin{array}{l}\text { Şcoala dispune de specialişti care pot oferi } \\
\text { servicii de sprijin educa ional (logopezi, } \\
\text { profesori de sprijin, profesori consilieri şcolari) }\end{array}$ & 14,7 & 16,7 & 6,4 & 17,9 & 28,8 & 14,7 \\
\hline $\begin{array}{l}\text { Şcoala asigură programe de educa ie remedială } \\
\text { pentru copiii cu rezultate slabe la învă ătură }\end{array}$ & 4,5 & 6,4 & 5,8 & 19,2 & 42,3 & 21,2 \\
\hline $\begin{array}{l}\text { Şcoala se implică în ajutorarea copiilor afla i în } \\
\text { situa ii deosebite (deces, accidente, interven ii } \\
\text { medicale etc.) }\end{array}$ & 0,6 & 5,8 & 4,5 & 19,2 & 39,7 & 30,1 \\
\hline $\begin{array}{l}\text { Activită ile educa ionale au în vedere cooperarea } \\
\text { între elevi }\end{array}$ & - & - & 1,3 & 6,4 & 53,8 & 38,5 \\
\hline $\begin{array}{l}\text { Există situa ii de segregare între elevi (pe criterii } \\
\text { etnice/socio-economice, fa ă de copiii cu CES, } \\
\text { fa ă de cei afla i sub măsuri de protec ie } \\
\text { specială: plasament de tip familial sau } \\
\text { reziden ial) }\end{array}$ & 10,9 & 21,2 & 17,9 & 14,1 & 20,5 & 14,7 \\
\hline
\end{tabular}

Notă: Ultimul item a fost codat invers: dezacordul total exprimă faptul că există multe cazuri de segregare în şcoala respondentului.

Sursa: https://scoli-prietenoase.ro/wp-content/uploads/2019/03/Raport-evaluare-profesoriADS_SDS.pdf, accesat pe 06.03.2020

\subsection{Dimensiunea Eficacitate}

Valorile mediilor rezultate în urma analizei răspunsurilor la itemii care descriu această dimensiune se situează între 4.7 (Răducăneni) şi 5.01 (Deleni); în ceea ce priveşte mediul în care func ionează şcoala, valorile mediilor sunt de 4.75 (urban) şi 4.96 (rural).

Profesorii care func ionează în mediul rural consideră că sunt mai eficace decât cei din mediul urban, mediile fiind ob inute prin agregarea răspunsurilor la itemii care apar în Tabelul nr. 6. De men ionat că itemii care compun această 
dimensiune nu evaluează direct gradul de atingere a unor obiective concrete, ci mai curând măsura în care cadrele didactice îşi cunosc sarcinile şi colaborează în îndeplinirea lor cu elevii, cu conducerea şcolii şi cu administra ia publică locală. Răspunsurile la fiecare item care compune dimensiunea avută aici în vedere sunt detaliate în Tabelul nr. 6.

Tabelul nr. 6. Itemii care compun variabila Eficacitate şi procentele răspunsurilor

\begin{tabular}{lcccccc}
\hline \multicolumn{1}{c}{ Ittem } & DT & D & DR & AR & A & AT \\
\hline $\begin{array}{l}\text { Elevii au o imagine clară cu } \\
\text { privire la educa ia lor ulterioară }\end{array}$ & 7,1 & 10,3 & 9,6 & 35,3 & 30,8 & 6,4 \\
\hline $\begin{array}{l}\text { Elevii ştiu în ce anume constă } \\
\text { activitatea de evaluare la toate } \\
\text { obiectele de studiu }\end{array}$ & 0,6 & 2,6 & 5,8 & 17,3 & 47,4 & 25,6 \\
\hline $\begin{array}{l}\text { Rezultatele şcolare, inclusiv la } \\
\text { evaluările de parcurs, sunt } \\
\text { înregistrate şi comunicate elevilor } \\
\text { şi, după caz, părin ilor }\end{array}$ & - & - & 1,9 & 3,2 & 36,5 & 57,7 \\
\hline $\begin{array}{l}\text { Produsele activită ii elevilor sunt } \\
\text { expuse în sălile de clasă şi în } \\
\text { celelalte spa ii ale şcolii }\end{array}$ & 0,6 & - & - & 2,6 & 40,4 & 56,4 \\
\hline $\begin{array}{l}\text { Conducerea şcolii eviden iază în } \\
\text { mod constant beneficiile educa iei } \\
\text { nonformale pentru atingerea } \\
\text { obiectivelor educa iei formale }\end{array}$ & 0,6 & 4,5 & 3,2 & 19,9 & 49,4 & 21,8 \\
\hline $\begin{array}{l}\text { Activită ile de învă are propuse } \\
\text { elevilor facilitează aplicarea } \\
\text { cunoştin elor în practică, în via a } \\
\text { reală }\end{array}$ & 0,6 & 3,2 & 5,8 & 32,1 & 41 & 17,3 \\
\hline $\begin{array}{l}\text { Elevii sunt implica i în proiecte } \\
\text { care au ca scop dezvoltarea } \\
\text { comunită ii }\end{array}$ & 5,1 & - & - & 19,9 & 50 & 23,7 \\
\hline $\begin{array}{l}\text { Oferta şi proiectarea CDS/CDL se } \\
\text { realizează pornind de la nevoile } \\
\text { specifice ale elevilor }\end{array}$ & 1,9 & 2,6 & 2,6 & 16,7 & 55,1 & 19,9 \\
\hline $\begin{array}{l}\text { Anual sunt ini iate proiecte } \\
\text { educa ionale în parteneriat cu } \\
\text { reprezentan ii comunită ii locale }\end{array}$ & 1,3 & 3,8 & 5,8 & 16 & 39,1 & 33,3 \\
\hline $\begin{array}{l}\text { Manualele si auxiliarele curriculare } \\
\text { sunt selectate în func ie de nivelul } \\
\text { dezvoltării cognitive a elevilor }\end{array}$ & - & 4,5 & 5,1 & 24,4 & 44,2 & 21,8 \\
\hline $\begin{array}{l}\text { Activită ile de predare, învă are şi } \\
\text { evaluare sunt proiectate în echipă } \\
\text { la nivelul catedrelor şi/sau între } \\
\text { ariile curriculare }\end{array}$ & 0,6 & 7,1 & 6,4 & 15,4 & 44,9 & 25,6 \\
\hline
\end{tabular}

Notă: Acolo unde procentul răspunsurilor nu atinge valoarea de 100\%, aceasta se datorează non-răspunsurilor. 
Din răspunsurile date, rezultă gradul ridicat în care profesorii consideră că îşi îndeplinesc sarcinile solicitate de profesie, împreună cu ceilal i actori implica i în procesul educativ (elev, conducere, comunitate). Cel mai mic nivel de acord este înregistrat de imaginea pe care o au elevii referitor la educa ia lor ulterioară, o activitate care, aparent, depinde şi de elev (şi de familia sa), nu doar de cadrul didactic.

\subsection{Dimensiunea Implicarea familiei elevilor}

Dacă familia nu în elege sau nu poate să asigure suportul şi sprijinul necesare copilului şi şcolii, efortul celei din urmă, oricât ar fi de sus inut, riscă să fie insuficient. Conform opiniei profesorilor, aşa cum rezultă din răspunsurile oferite la chestionar, colaborarea cu părin ii nu este foarte bună, mediile pe localită i ob inute de această dimensiune variind între 4.22 şi 4.44. În func ie de mediul de reziden ă în care func ionează şcolile, mediile sunt de 4.24 (rural) şi 4.32 (urban).

Răspunsurile la itemii care compun această dimensiune apar în Tabelul nr. 7.

În urma centralizării mediilor pentru fiecare dintre cele patru dimensiuni cercetate care au întrunit criteriul de validitate, pentru fiecare şcoală, s-au ob inut rezultatele care apar în Tabelul nr. 8 şi în Graficul nr. 1 .

Problema siguran ei este cea mai importantă, aceasta ob inând mediile cele mai mici în fiecare localitate. Următoarea variabilă care a ob inut cele mai mici medii după siguran ă este cea a rela iei cu familia, ceea ce exprimă distan a semnificativă percepută de către cadrele didactice fa ă de familiile copiilor. Mediile cele mai mari, care reflectă cea mai importantă resursă a şcolii, sunt ob inute de încredere (la Podu Iloaiei, Erbiceni, Hârlău şi Răducăneni) şi eficacitate (la Deleni şi Pârcovaci). Cele două variabile au ob inut cele mai mari medii în fiecare dintre cele şase localită i.

Centralizarea reprezentărilor aceloraşi dimensiuni în func ie de mediul de reziden ă în care func ionează şcoala apar în Graficul nr. 2. 
Tabelul nr. 7. Itemii care compun variabila Implicare a familiei şi procentele răspunsurilor pentru fiecare item

\begin{tabular}{|c|c|c|c|c|c|c|}
\hline Item & DT & D & DR & $\mathbf{A R}$ & $\mathbf{A}$ & AT \\
\hline $\begin{array}{l}\text { Există comunicare } \\
\text { permanentă cu părin ii } \\
\text { (reprezentan ii legali ai) } \\
\text { tuturor elevilor }\end{array}$ & 0,6 & 2,6 & 1,9 & 21,8 & 47,4 & 25 \\
\hline $\begin{array}{l}\text { Părin ii elevilor îşi spun } \\
\text { opinia cu privire la calitatea } \\
\text { procesului educa ional }\end{array}$ & & 6,4 & 3,2 & 27,6 & 50 & 12,8 \\
\hline $\begin{array}{l}\text { Când sunt solicita i, părin ii se } \\
\text { implică în via a şcolară a } \\
\text { copiilor }\end{array}$ & & 5,1 & 4,5 & 32,7 & 46,2 & 11,5 \\
\hline $\begin{array}{l}\text { Familia asigură copiilor } \\
\text { condi ii adecvate pentru } \\
\text { pregătirea lec iilor }\end{array}$ & & 10,9 & 15,4 & 46,2 & 25 & 2,6 \\
\hline $\begin{array}{l}\text { Părin ii acordă importan ă } \\
\text { educa iei ca şansă de } \\
\text { dezvoltare a copiilor }\end{array}$ & 0,6 & 5,1 & 13,5 & 41,7 & 35,9 & 3,2 \\
\hline $\begin{array}{l}\text { Părin ii sunt interesa i de } \\
\text { dezvoltarea şi progresele } \\
\text { realizate de proprii lor copii }\end{array}$ & 0,6 & 5,1 & 6,4 & 36,5 & 37,2 & 14,1 \\
\hline $\begin{array}{l}\text { Părin ii vin din proprie } \\
\text { ini iativă la şcoală pentru a se } \\
\text { sfătui cu cadrele didactice în } \\
\text { privin a problemelor copiilor } \\
\text { lor }\end{array}$ & 1,9 & 11,5 & 9 & 51,3 & 20,5 & 5,8 \\
\hline $\begin{array}{l}\text { În şcoală se organizează } \\
\text { pentru părin i sesiuni de } \\
\text { consiliere individuală sau în } \\
\text { grup mic (discu ii cu } \\
\text { psihologul sau consilierul } \\
\text { şcolii) }\end{array}$ & 3,8 & 7,1 & 9,6 & 26,3 & 37,2 & 16 \\
\hline $\begin{array}{l}\text { Şcoala organizează cursuri } \\
\text { pentru părin i, întâlniri cu } \\
\text { specialişti în diferite domenii } \\
\text { (medici, logopezi, psihologi, } \\
\text { consilieri etc.) }\end{array}$ & 3,8 & 12,2 & 10,3 & 32,1 & 30,1 & 11,5 \\
\hline $\begin{array}{l}\text { Părin ii participă la luarea } \\
\text { deciziilor privind via a şcolii } \\
\text { (de ex., privitoare la } \\
\text { curriculum, evaluare, } \\
\text { gestionare a resurselor) }\end{array}$ & 1,9 & 10,9 & 11,5 & 32,1 & 34,6 & 9 \\
\hline
\end{tabular}

Sursa: https://scoli-prietenoase.ro/wp-content/uploads/2019/03/Raport-evaluare-profesori ADS_SDS.pdf, accesat pe 06.03.2020 
Tabelul nr. 8. Centralizarea răspunsurilor pe localită $i$ şi pe dimensiuni

\begin{tabular}{lcccccc}
\hline & $\begin{array}{c}\text { Podu } \\
\text { Iloaiei }\end{array}$ & Erbiceni & Hârlău & Deleni & Pârcovaci & Răducăneni \\
\hline Incredere & 4,86 & 4,87 & 4,90 & 5 & 4,80 & 4,82 \\
\hline Siguran ă & 4,04 & 4,07 & 4,39 & 3,75 & 3,55 & 3,78 \\
\hline Eficacitate & 4,81 & 4,83 & 4,76 & 5,01 & 4,92 & 4,70 \\
\hline $\begin{array}{l}\text { Rela ia cu } \\
\text { familia }\end{array}$ & 4,33 & 4,23 & 4,40 & 4,25 & 4,22 & 4,25 \\
\hline
\end{tabular}

Sursa:http://scoli-prietenoase.ro/wp-content/uploads/2020/03/Raport-analiza_chestionareprofesori_preinterventie.pdf, accesat pe 06.03.2020

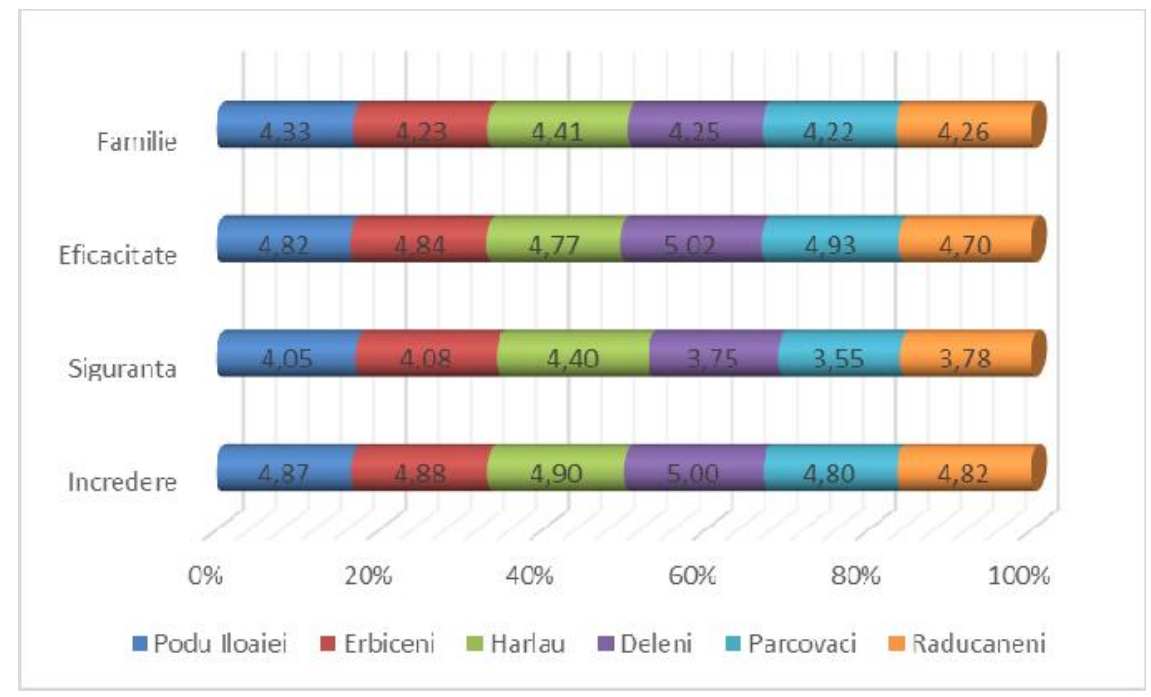

Graficul nr. 1. Centralizarea răspunsurilor pe localită i (şcoli) şi pe dimensiuni 


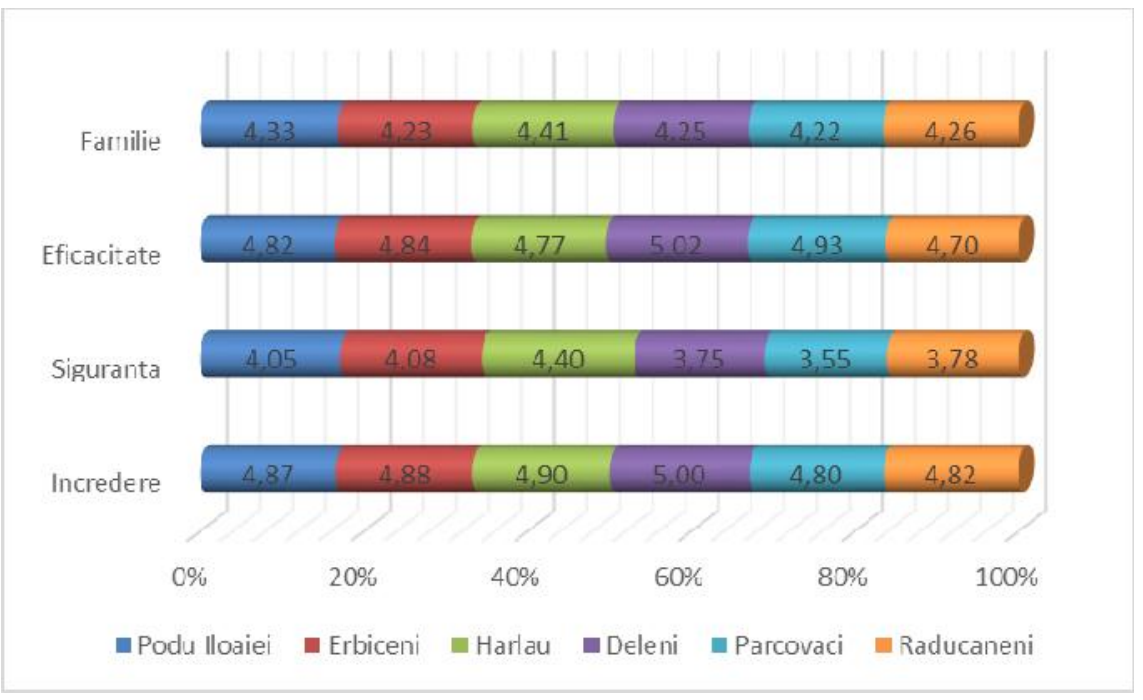

Graficul nr. 2. Centralizarea răspunsurilor în func ie de mediul de reziden ă în care func ionează şcolile şi pe dimensiuni

Notă: În acest grafic au fost excluse răspunsurile responden ilor care nu au precizat localitatea de provenien $\breve{a}$

Aşa cum am men ionat în cazul fiecărei variabile şi cum reiese din Graficul nr. 2, în mediul rural cadrele didactice consideră că elevii au mai multă încredere în ei şi în şcoală şi că dau dovadă de mai multă eficacitate, în compara ie cu colegii lor din mediul urban. Totuşi, în rural, siguran a şi rela ia cu familia sunt percepute ca fiind probleme mai grave decât la oraş, în condi iile în care acestea sunt evaluate negativ în toate şcolile în care am făcut cercetarea.

\section{Discu ii}

Datele prezentate permit eviden ierea punctelor tari şi punctelor slabe ale şcolilor avute în vedere din perspectiva modelului SPC. Un aspect pozitiv este reprezentat de faptul că datele statistice ob inute de noi confirmă că încrederea este promovată ca element-cheie al culturii şcolare, fiind astfel valorizate integrarea în grup şi starea de bine a tuturor copiilor. Încrederea în şcoală este tratată în literatura de specialitate ca o caracteristică de grup (Adams, 2014), fiind rezultanta interac iunii şi a experien elor comune ale elevilor. 
Totodată, cadrele didactice recunosc faptul că elevii apelează în relativ mică măsură la ajutorul lor atunci când se confruntă cu probleme personale sau familiale. Constatăm existen a unei rupturi în ceea ce priveşte contextul intern şi cel extern al organiza iilor şcolare, elevii obişnuind să separe via a personală de ceea ce se întâmplă la şcoală. Considerăm că acest aspect reprezintă un punct slab al şcolilor, ştiut fiind faptul că factorii din mediul extern modelează atitudinile, credin ele şi comportamentele elevilor (Adams, 2014), contribuind la dezvoltarea lor ca persoane independente şi autonome. Şcolile eficiente şi prietenoase copilului sunt preocupate să creeze un echilibru între mediul extern şi cel specific şcolii, realizând adaptarea cerin elor educa ionale la specificul şi nevoile concrete ale elevilor (Forsyth et al., 2011).

Medii mari au fost înregistrate şi pentru dimensiunea eficacitate, care a fost evaluată chiar de către cadrele didactice. În Graficul nr. 2 se poate observa că în mediul rural, ambele dimensiuni - încredere şi eficacitate - au valori mai mari decât în cel urban. Cu toate acestea, clasamentul rămâne relativ, dimensiunile fiind comparate între ele şi nu în valori absolute în care maximul mediei ar fi fost 6 . Eficacitatea, din perspectiva SPC, presupune relevan a curriculumului pentru via a de zi cu zi a copiilor şi dezvoltarea motiva iei acestora de a planifica un parcurs educa ional de lungă durată. Valorile mici ale mediilor care se referă la aceste aspecte demonstrează faptul că este necesar ca şcolile să realizeze o adaptare mai accentuată a demersului educa ional la nevoile specifice elevilor.

Cea mai gravă problemă care a rezultat din analiza răspunsurilor este siguran a de care se bucură copiii şi cadrele didactice în şcoală. Deşi profesorii au răspuns, în majoritate, că şcoala în care muncesc este un mediu sigur, aceiaşi responden i au precizat că în şcoală se înregistrează, în diferite grade, distrugeri, abuzuri verbale, bătăi. Este discutabil în ce măsură aceşti indicatori dau într-adevăr măsura siguran ei în şcoală. Modul în care au fost formulate întrebările şi răspunsurile şi-a propus să cuantifice starea de lucruri pe un continuum de la minim la maxim. Este însă posibil să nu fi reuşit acest lucru şi întrebarea să fi fost percepută ca una dihotomică, în sensul în care oricât de pu ine incidente ar fi înregistrate în şcoală, ele există, sunt considerate a fi intolerabile, deci grave. Aceasta ine şi de o percep ie subiectivă a acestor evenimente care influen ează răspunsurile. Cel care a trăit sau măcar a auzit de un abuz, de exemplu, îl va considera un eveniment 
extrem de grav, deşi evenimentul respectiv poate fi singular în şcoală.

Statistic, prin calculul mediilor răspunsurilor a rezultat că problema siguran ei este cea mai gravă în viziunea celor care au răspuns la chestionar, mai preocupantă această problemă fiind în mediul urban (medie de 4.04), fa ă de mediul rural (medie de 3.84).

Urmează, în ordinea preocupărilor responden ilor, rela ia pe care o are şcoala cu familiile elevilor, în sensul împlicării părin ilor în sprijinul copiilor şi al cadrelor didactice. Mediile sunt mai mari decât cele care descriu siguran a şi protec ia, însă semnificativ mai mici decât cele care se referă la încredere şi eficacitate, ceea ce poate duce la concluzia, în acest clasament relativ, că rela ia cadrelor didactice cu familiile elevilor este mai curând mediocră. Din Tabelul 8 rezultă că părin ii - aşa cum consideră cadrele didactice - au o implicare redusă în sprijinul procesului educativ, ceea ce poate să influen eze negativ rezultatele şcolare ale copiilor şi atingerea obiectivelor şcolii. Meta-analize recente în care au fost incluse studii realizate între 2000 şi 2013 sugerează că implicarea părin ilor în activită i asociate cu şcoala are un efect pozitiv moderat asupra performan ei şcolare a elevilor, la toate nivelurile de învă ământ (Castro et al., 2015, apud oc, 2016).

\section{Concluzii}

inând seama de literatura de specialitate, resursele sociale ale şcolii - care in de organizare şi de rela ii - pot fi opera ionalizate pe numeroase dimensiuni. Noi am construit un astfel de instrument structurat pe cinci factori - încrederea copiilor în şcoală, siguran ă şi protec ie, incluziune şi suport, eficacitate, implicarea familiei - pe care le-am opera ionalizat prin intermediul a 35 de itemi. În urma analizei consisten ei instrumentului, am constatat faptul că dimensiunea incluziune şi suport, care se referă la capacitatea şcolii de a fi un sprijin pentru elevi, mai ales al celor vulnerabili (cu dizabilită i, săraci, afla i în măsuri de protec ie etc.) nu a întrunit criteriile de fidelitate şi, din acest motiv, nu am mai inclus-o în analiza comparativă cu celelalte variabile. Cu toate acestea, ne păstrăm convingerea că un instrument care îşi propune să măsoare resursele sociale ale şcolii trebuie să con ină o astfel de dimensiune, dar care să întrunească standardele statistice de consisten $\breve{\text { a. }}$ 
Instrumentul propus, la care au răspuns 156 de cadre didactice din şase şcoli din zone defavorizate din jude ul Iaşi, ne-a permis să constatăm că nesiguran a în şcoală şi calitatea rela iei cu părin ii sunt dimensiunile ce pot fi considerate puncte slabe din perspectiva cadrelor didactice respondente. Este nevoie ca şcolile să manifeste preocupare pentru realizarea unui echilibru între mediul extern şi cel intern al organiza iei, prin orientarea aten iei cadrelor didactice spre adaptarea demersului educa ional, pentru satisfacerea nevoilor personale şi educa ionale ale elevilor.

Din punct de vedere metodologic, considerăm că un astfel de demers trebuie completat cu date ob inute prin aplicarea de tehnici calitative. $\mathrm{O}$ abordare metodologică mixtă va permite ob inerea de informa ii esen iale şi complete, necesare deciden ilor în vederea transformării organiza iilor şcolare din medii defavorizate, în şcoli eficiente şi prietenoase copilului, în factori pozitivi de dezvoltare individuală şi comunitară.

\section{Mul umiri}

Precizăm că datele au fost ob inute în cadrul Proiectului „Şcoli prietenoase în comunită i implicate", proiect cofinan at din Fondul Social European, derulat în cadrul Programului Ocupa ional Capital Uman (2014-2020), Axa prioritară Educa ie şi competen e OS 6.2, 6.3, 6.4, 6.6, Cod contract POCU/74/6/18 - Cod SMIS: 106616. Proiectul este implementat în perioada 2018-2021 de Inspectoratul Şcolar Jude ean Iaşi în parteneriat cu Asocia ia HoltIS Iaşi şi Funda ia COTE Iaşi.

\section{Referin e}

- Adams, C. M. (2014). Collective Student Trust: A Social Resource for Urban Elementary Students. Educational Administration Quarterly, 50(I), 135-159. https://doi.org/10.1177/001361X13488596

- Babbie, E. (2010). Practica cercetării sociale. Polirom.

- Bowles, S., \& Gintis, H. (1976). Schooling in Capitalist America. Basic Books.

- Bryk, A. S., Sebring, P. B., Allensworth, E., Luppescu, S., \& Easton, J. Q. (2010). Organizing schools for improvement: Lessons from Chicago. The University of Chicago Press.

- Coleman, J. S., Campbell, E., Hobson, C., McPartland, J., Mood, A., Weinfeld, F., \& York, R. (1966). Equality of Educational Opportunity. USPO. 
- Corwin, R. G., \& Borman, K. M. (1988). School as a workplace: Structural constraints on administration. In N.J. Boyan (Ed.), Handbook of research on educational administration (pp. 209-237). Longman.

- Cristea, S. (2008). Calitatea în educa ie/educa ia de calitate. Didactica Pro..., 4-5(50-51), 107-112.

- Finley, S. J. (2000). Instructional Coherence: The Changing Role of the Teacher. Southwest Educational Development Laboratory.

- Forsyth, P. B., Adams, C. M., \& Hoy, W. K. (2011). Collective trust: Why schools can't improve without it. Teachers College Press.

- Fullan, M. G. (2007). The Meaning of Educational Change (4th ed.). Teachers College Press.

- Gamoran, A., \& Long, D. (2016). Equality of Educational Opportunity: a 40Year Retrospective. University of Wisconsin-Madison: Wisconsin Center for Education Research.

- George, D., \& Mallery, P. (2003). SPSS for Windows step by step: A simple guide and reference (11th ed.). Allyn \& Bacon.

- Godfrey, B. E., Osher, D., Williams L. D., Wolf, S., Berg, J. K., Torrente, C., Spier, E., \& Aber, L. J. (2012). Cross-national measurement ofschool learning environments: Creating indicators for evaluating UNICEF's Child Friendly Schools Initiative. Children and Youth Services Review, 34(3), 545-557. https://doi.org/10.1016/j.childyouth.2011.10.015

- Hanselman, P., Grigg, J. K., Bruch, S., \& Gamoran, A. (2016). The Consequences of Principal and Teacher Turnover for School Social Resources. In G. Kao \& H. Park (Eds.), Family Environments, School Resources, and Educational Outcomes (pp. 49-89). Emerald Group Publishing Limited.

- Hargreaves, A. (1995). Development and Desire: A Postmodern Perspective. In T. Guskey \& M. Huberman (Eds.), Professional Development in Education: New Paradigms and Practices. Teachers' College Press.

- Hargreaves, A. (1998). The emotional practice of teaching. Teaching and Teacher Education, 14(8), 835-854.

https://doi.org/10.1016/S0742-051X(98)00025-0

- Hatos, A. (2019). Impactul structurii familiei asupra rezultatelor la testele de competen e PISA 2012. In G. Bădescu (Ed.), Şcoala din România din perspectiva datelor PISA (pp. 33-58). Presa Universitară Clujeană.

- Hoy, W. K., Tarter, C. J., \& Bliss, J. (1990). Organizational climate, school health, and effectiveness: A comparative analysis. Educational Administration Quarterly, 26(3), 260-279. https://doi.org/10.1177/0013161X90026003004

- Hopkins, D. (2004). School Improvement for Real. Taylor \& Francis e-Library.

- Jensen, A. (1969). How much can we boost IQ and scholastic achievement? Harvard Educational Review, 39(1), 1-123. 
- Kaplan, S. L., \& Owings, A. W. (2013). Reinvigoreiting School Culture to Improve Student Outcomes. SAGE Publications Ltd.

- Miles, M. B. (1967). Some properties of schools as social systems. In G. Watson (Ed.), Change in Schools Systems. National Training Laboratories.

- Seashore, L. K., \& Lee, M. (2016). Teachers' capacity for organizational learning: the effects of school culture and context. School Effectiveness and School Improvement, 27(4), 534--556.

https://doi.org/10.1080/09243453.2016.1189437

- Tufiş, P. A. (2008). Predictors of school success in Romania. Family background, school factors, and community factors. Revista Calitatea Vie ii, XIX(3-4), 389-405.

- oc, S. (2016). Familie, şcoală şi succes şcolar în învă ământul liceal românesc. Revista Calitatea vie ii, 27(3), 189-215.

- Uline, C. L., Miller, D. M., \& Tschannen-Moran, M. (1998). School Effectiveness: The Underlying Dimensions. Educational Administration Quarterly, 34(4), 462-483. https://doi.org/10.1177/0013161X98034004002

- UNICEF. (2012). Şcoala prietenoasă copilului: Raport de evaluare externă a Ini iativei „Şcoala prietenoasă copilului” (2007-2011).

https://www.unicef.org/evaluation/files/Moldova_2012_002_CFS_RO_PRINT.pdf

The online version of this article can be found at: http://revped.ise.ro/category/2020-en/

\section{(oc) EY-NC-SA}

This work is licensed under the Creative Commons Attribution-NonCommercial-ShareAlike 4.0 International License.

To view a copy of this license, visit http://creativecommons.org/licenses/by-nc-sa/4.0/ or send a letter to Creative Commons, PO Box 1866, Mountain View, CA 94042, USA.
Versiunea online a acestui articol poate fi găsită la: http://revped.ise.ro/category/2020-ro/

\section{(cC) DY-NC-SA}

Această lucrare este licen iată sub Creative Commons Attribution-NonCommercial-ShareAlike 4.0 International License.

Pentru a vedea o copie a acestei licen e, vizita $i$ http://creativecommons.org/licenses/by-nc-sa/4.0/ sau trimite i o scrisoare către Creative Commons, PO Box 1866, Mountain View, CA 94042, SUA. 


\title{
THE PRESENCE OF ROMA LIFE'S EXPERIENCES, TRADITIONS AND HISTORY IN THE ROMANIAN TEXTBOOKS - A CONTENT ANALYSIS FROM A SOCIAL JUSTICE PERSPECTIVE
}

\section{Cristina Tunegaru*}

\author{
University of Bucharest, \\ Faculty of Psychology and Educational Sciences, \\ Bucharest, Romania \\ cristina.tunegaru@gmail.com
}

\begin{abstract}
Roma people have been victims of oppression in Romania for many centuries, "in the long course of the Gypsy experience in Eastern Europe, none has been worse than that in Romania" (Crowe \& Kolsti, 1991, p. 61). Nowadays, education can play a key role in assuring that the Roma are treated with respect and dignity, in assuring that they receive recognition, while dismantling the stigma.

This paper is the outcome of a study of the representation of minority students in Romanian textbooks. While many educational reforms were targeted to increase Roma students' attendance and results - schools with Roma language teaching, textbooks in Roma native language, affirmative actions for high school and university students of Roma origin - it's an open question as to whether the Romanian textbooks are sufficiently inclusive and effective in combating racial discrimination and stereotyping.

By employing a social justice perspective, I argue that textbooks systematically discriminate against Roma children by under- and misrepresenting the Roma experiences, traditions and history. My argument unfolds through two main directions from the data analysis. Firstly, we examine primary and middle school (2nd grade 6th grade) textbooks in search for representations of Roma realities and culture. Secondly, we explore the presentation or absence of historical facts regarding Roma. This exploratory study hopes to become a starting point for a discussion about
\end{abstract}

* PhD Candidate, University of Bucharest, Faculty of Psychology and Educational Sciences, Bucharest, Romania. 
applied curriculum in Romania, specifically the textbook component. Limited comparative data was collected and stark differences can be inferred between the attention devoted to Hungarian culture and realities versus the Roma, but further research is warranted.

Keywords: minorities, oppression, Roma, social justice.

\section{Rezumat}

Persoanele apar inând minorită ii rome au fost victime ale opresiunii în România timp de mai multe secole, , în lunga prezen ă a romilor în Europa de Est, nicăieri experien a lor nu a fost mai grea decât în România" (Crowe \& Kolsti, 1991, p. 61). În prezent, educa ia poate juca un rol cheie în a garanta că romii sunt trata $i$ cu respect şi demnitate, că primesc recunoaştere fără a fi stigmatiza $i$.

Această lucrare este rezultatul unui studiu privind reprezentări ale minorită ilor în manualele româneşti. În vreme ce multe reforme educa ionale au avut ca obiectiv îmbunătă irea prezen ei la cursuri şi a rezultatelor şcolare - şcoli cu predare în limba romani, manuale în limba romani, locuri rezervate la liceu şi facultate pentru elevii de etnie romă - rămâne o intrebare deschisă măsura în care manualele româneşti sunt suficient de incluzive şi eficiente în combaterea discriminării rasiale şi a stereotipurilor.

Utilizând perspectiva justi iei sociale, argumentăm că manualele discriminează sistematic elevii romi prin subreprezentarea experien elor, a tradi iilor şi a istoriei rome. Analiza datelor permite explorarea a două direc ii de argumentare. In primul rând, am examinat manualele pentru şcoala primară şi gimnazială (clasele a II- $a$ - a VI-a) căutând reprezentări ale realită ilor şi culturii rome. În al doilea rând, am explorat prezen a sau absen a datelor istorice referitoare la etnia romă. Sperăm ca această explorare să devină un punct de plecare pentru o discu ie despre curriculumul aplicat din România, componenta analizată în cazul nostru fiind manualele şcolare aprobate de Ministerul Educa iei. S-a colectat, de asemenea, o cantitate limitată de date comparative care sugerează o aten ie dispropor ionată pentru minoritatea maghiară în raport cu cea romă, aceste date deschizând posibilitatea unor cercetări ulterioare.

Cuvinte-cheie: justi ie socială, minorită $i$, opresiune, romi. 


\section{Introduction}

The Roma living in Romania have a long history of socio-economic problems, poverty, marginalization, isolation and invisibility. Only in the second half of the 19th century, the enslaving of the Roma in Romania ceased. However, the free Roma were not given the opportunities to prosper, instead they were segregated at the periphery of the cities and lived in deprivation and returned to their traditional occupations. As has happened throughout the Eastern bloc, the communist regime tried to erase every ethnic characteristic, and the Roma began to be assimilated (Elleh, 2014). Only after 1989, after the fall of the communist regime, the Roma gained their place as a minority, the second biggest minority in Romania. However, the great majority of the Roma still experience poverty and deprivation, with 3 out of 5 Roma still living in destitution in 2008 (Fleck \& Rughiniş, 2008).

Roma children face great challenges in school, as the number of drop outs within the Roma population are more than six time the baseline values, indeed, more than $80 \%$ of drop outs are Roma children (Ivan \& Rostas, 2013). The power dynamic which renders Roma groups as marginals generates a series of survival strategies, in order to resist external forces of assimilation and to preserve the cultural legacy, what Carol Silverman calls "the negotiation of Gypsiness" (as cited in Barany, 1994, p. 325). For this reason, the real number of ethnic Roma is unknown.

In order to address these problems, a series of policies were implemented by the Ministry of Education. First, the Roma groups were acknowledged as a national minority with specific educational demands. Second, affirmative action policies for the Roma were implemented. Third, classes and schools teaching in Rromani language started to develop around the country. Alongside this development, a curriculum for the Roma was implemented and textbooks for the subject of Rromani language were created. In addition, the Ministry of Education developed two optional courses for Roma students, concerning the history and the culture of Roma groups.

However, the issue of Rromani teaching in Romania faces a number of problems. First, Roma groups are very diverse in Romania (Barany, 1994), 
not all groups speak Rromani language. The Roma are not a people, rather they constitute social groups with various characteristics.

Second, there is a shortage of teachers specialized in Rromani language. After the Romanian Revolution, one university in the country started to offer a program for Rromani language (Ştefănescu, 2005). Our own research was unable to identify any new Rromani section being established in the intervening decades, with the exception of optional Rromani language courses. Considering the number of Roma reaching university is very small, only a few teachers specialized in Rromani language graduate each year. When there are not specialized teachers in the school, the optional courses are not available.

Third, due to the stigma associated with being Roma, a great number of people deny their ethnicity. Certain policies of affirmative action are associated with a positive impact on formal ethnical identification of Roma people.

Another problem is school segregation, a phenomenon which manifests at many levels: inside the classroom, when students of low socio-economic background are placed at the back of the classroom; between classes of the same level, when students are placed discriminatory in specific classes according to their background or performance at the school level, when Roma children study in a different building than their non-Roma peers. Segregation has a profound negative impact on the educational provision (Greenberg, 2010). Schools tend to do their best for the high-performance classes: the best teachers, better educational experiences, while lessening their expectation and their involvement for the less-performing classes. In segregated classes, Roma students are enrolled in Roma classes or sent to schools with a predominant Roma population. In both situations the educational provision is poorer than for the rest of the population (Petrova, 2003).

\section{Cultural imperialism and textbooks}

The marginal status of Roma groups in Romania requires a social justice perspective in the educational field. In her theory of social justice, Iris Young 
(1990) develops a framework in which justice is examined through forms of injustice, materialized in oppression and domination. We have employed the concept of oppression in regard to textbook representations in order to explore the textual and visual representations of Roma history, personalities, culture in textbooks for primary and middle education, grades 2 nd-6th.

In Young's view, oppression "refers to systemic and structural phenomena" (idem, p. 270) "that immobilize or reduce a group" (idem, p. 272). The structural nature of oppression relies in the everyday practices, common narratives, gestures, attitudes of people who don't see themselves as oppressors. Oppression acts almost invisibly through social manifestations which are rendered as usual, acceptable. While the oppressor must not be seen as a tyrant who acts intentionally to limit or reduce one specific group, "the oppressed people share some inhibition of their ability to develop and exercise their capacities and express their needs, thoughts, and feelings" (ibidem). When injustice manifests, it affects people who identify with a specific social group. As Young points out, individuals don't choose to be part of a group, instead they find themselves part of a social group. One can identify with more than one group, so groups overlap.

The national curriculum, the result of a consensus regarding educational ideals and objectives, is a communicative tool. Curriculum includes "not only texts, but also other instructional materials, programs, projects, physical environments for learning, interactions among teachers and students, and all the intended and unintended messages about expectations, hopes, and dreams that students, their communities, and schools have about student learning and the very purpose of schools" (Nieto et al., 2008, p. 176). This exploratory study focuses only on the textbook curricular component and it is intended as a starting point for a discussion about minority representation and educational outcomes that should involve the entire educational process. In regard to textbooks, oppression can manifest through cultural imperialism; the term is defined by Young as follows:

"The experience of existing with a society whose dominant meanings render the particular perspectives and point of view of one's own group invisible at the same time as they stereotype one's group and mark it out as the Other." (Young, 1990, p. 285) 
Two key points emerge from the definition: first, cultural imperialism creates a hierarchy of values within society, the point of view of one group becomes the norm, the acceptable, while the others are marked as different, wrong, unacceptable. Second, the universalization together with the validation of the dominant group's experiences, creates a set of stereotypes used to devalue the difference, which furthermore immobilize and limit one's possibilities and potential. Oftentimes, the dominant group's cultural views are described as unique, "representative of humanity as such" (ibidem). We argue that the Roma life's experiences, traditions and history are less present in student textbooks. The absence can be a form of oppression, as it becomes a communicative instrument for what is meaningful.

Textbooks are interpretations of the curriculum by their respective authors and teachers can choose between alternative textbooks. In Romania, textbooks have gained authority, they comprise what is valuable to be transmitted to next generations, what is acceptable and worthy. Through text, image, the presence or the absence, textbooks map the meaningful cultural, social, economic, political knowledge. The choice of integrating one group's experiences and ignoring another group from textbooks are forms of cultural imperialism.

\section{Methodology}

The current study aims to investigate the ways in which Roma realities are portrayed in textbooks of 2-6 grades. The research question is focused around the number of references to Roma, the manner of presentation in textbooks for students, the extent of the references, as well as the illustrations depicting Roma. The choice of the textbook sample is in line with recent curricular reforms that have prompted the publication of new textbooks for children that started school in 2013. The older textbooks for grades 7 and 8 are soon to be obsolete and the 1st grade textbooks are not pertinent to the study. Indeed, even the 2nd grade textbooks include no references to Roma and minorities, the first general references to diversity beginning in the 3rd grade.

The research method used is content analysis which brings together qualitative and quantitative elements. As Holsti $(1969$, p. 14) points out, 
"content analysis is any technique for making inferences by objectively and systematically identifying specified characteristics of messages".

Through this research we have examined a number of 189 student textbooks currently used in primary education (for 2 nd - 4th grades), 5 th and 6th grades. Table 1 comprises the number of textbooks included in the analysis.

The data was collected through content analysis of all the textbooks that matched our criteria made available online by the Education Ministry on the dedicated platform (http://manuale.edu.ro). The platform was accessed in August 2019 and the selection criteria were grades 2-6, published in Romanian, according to the revised curriculum. Publication dates were between 2016 and 2018 inclusively.

Table no. 1. Number of student textbooks by subject and grade

\begin{tabular}{|c|c|c|c|c|c|}
\hline \multirow{2}{*}{ Subject } & \multicolumn{5}{|c|}{ Number of student textbooks } \\
\hline & $2^{\text {nd }}$ grade & $3^{\text {rd }}$ grade & $4^{\text {th }}$ grade & $5^{\text {th }}$ grade & $6^{\text {th }}$ grade \\
\hline $\begin{array}{l}\text { Romanian } \\
\text { Language }\end{array}$ & 4 & 6 & 4 & 9 & 2 \\
\hline Mathematics & 4 & 6 & 2 & 7 & 2 \\
\hline TIC & & & & 6 & 3 \\
\hline Science/ Biology & & 6 & 5 & 9 & 2 \\
\hline Geography & & & 6 & 6 & 1 \\
\hline $\begin{array}{c}\text { Personal } \\
\text { Development }\end{array}$ & & & & 5 & \\
\hline Physics & & & & & 2 \\
\hline History & & & 4 & 8 & 1 \\
\hline Religion & 4 & 6 & 9 & 2 & 2 \\
\hline Music & & 6 & 6 & 2 & 2 \\
\hline Sports & & & & 3 & 1 \\
\hline Technological Ed & & 4 & 2 & 6 & 2 \\
\hline Arts (painting) & & & & 1 & 1 \\
\hline Social education & & 6 & 4 & 8 & 2 \\
\hline Total & 12 & 40 & 42 & 72 & 23 \\
\hline
\end{tabular}


The textbooks were searched for Romanian words pertinent to the research subject: rom/rrom, igan, etnic/etnie, minoritate. When possible, the textbooks were searched digitally for an appropriate stem in order to find all inflexions and diacritical forms (e.g., *igan*, *igăn*, *rom*, minor*, etc.); a minority of textbooks were manually searched as the format precluded digital search. The data was coded and put into themes: visual, textual, historical, etc.

We have employed Zacho's (2017) framework and their categories for analysis: 1) number of references; 2) extent of references: short or long texts; 3) character of the references: positive or negative; 4) manner of description. Zacho's instrument is useful, as it allows to organize and structure the extent to which one group is present in the textbook imaginary. Consequently, the analysis follows, through closely monitored steps, first, a quantitative approach and then a qualitative approach to effectively deconstruct and interpret the data.

\section{Limitations}

This study refers to textbooks for 2nd-6th grades published in 2016-2018. Consequently, we have only analyzed textbooks corresponding to two years out of four years of middle school compulsory education. We have employed a comparative approach focusing on Roma and Hungarian representations in primary school textbooks. This comparative analysis is limited to textbooks until grade 5 .

Notably, the textbooks offer the author's perspective on the themes included in the curriculum. The texts, the classroom activities, the exercises and the projects represent the author's interpretation of the curriculum.

\section{Results}

\subsection{Number of references}

The words rom and igan referring to the Roma minority appear for 76 times. Table 2 includes the number of references and the textbooks where they appear. 
Table no. 2. Number of references by grade and subject

\begin{tabular}{|c|c|c|c|c|c|c|c|}
\hline \multirow{2}{*}{$\begin{array}{c}\text { Student } \\
\text { textbook }\end{array}$} & $\begin{array}{c}\text { Number of references } \\
\text { 2nd and 3rd grade }\end{array}$ & \multicolumn{2}{|c|}{$\begin{array}{c}\text { Number of references } \\
\text { 4th grade }\end{array}$} & $\begin{array}{c}\text { Number of references } \\
\text { 5th grade }\end{array}$ & \multicolumn{2}{c|}{$\begin{array}{c}\text { Number of references } \\
\text { 6th grade }\end{array}$} \\
\cline { 2 - 8 } & Rom/Rrom/ igan & Rom/Rrom & igan & Rom/Rrom & igan & Rom/Rrom & igan \\
\hline $\begin{array}{c}\text { Romanian } \\
\text { Language }\end{array}$ & 0 & 0 & 0 & 3 & 7 & 0 & 0 \\
\hline History & 0 & 9 & & 0 & 0 & 0 & 0 \\
\hline $\begin{array}{c}\text { Social } \\
\text { Education }\end{array}$ & 0 & 2 & & 35 & 1 & 9 & 1 \\
\hline Musics & 0 & 0 & 1 & 0 & 0 & 0 & 0 \\
\hline Geography & 0 & 8 & & 0 & 0 & 0 & 0 \\
\hline Total & $\mathbf{0}$ & $\mathbf{1 9}$ & $\mathbf{1}$ & $\mathbf{3 8}$ & $\mathbf{8}$ & $\mathbf{9}$ & $\mathbf{1}$ \\
\hline
\end{tabular}

As previously explained, the references to Roma are very rare in primary school textbooks - grades 2-4. No references to Roma can be found in textbooks for 2 nd and 3 rd grades. However, diversity is discussed in general terms, rather using international, than local references.

While some discussion about diversity is introduced in 2nd and 3rd grade textbooks, the Roma are mentioned starting with 4th grade History textbooks. Nonetheless, the word Roma is used mainly for the purpose of enumerating the minorities living in the country (Geography, Aramis, 4th grade, pp. 50-51; Geography, Arthur, 4th grade, p. 54; Geography, Intuitext, 4th grade, p. 26; History, Aramis, 4th grade, p. 41; Social Ed., Aramis, 4th grade, p. 16; Social Ed., CdPress, 4th grade, p. 23).

There is little information about the financial, economic or social status of the Roma. Only one paragraph offers general information about this minority. However, it emphasizes the otherness of the Roma, by pointing out the Indian origin, their nomadic character, their traditional occupations which are related to poverty, marginalization and isolation. The discourse conveys a group of people different from the Romanian majority by means of occupation, language and origin which inhabit Romania designated as our land. According to the paragraph reproduced below, the Roma still live in a pre-modern state, strangers among other cultures:

"The Roma have their origin in medieval India. Being nomads (travelers without a stable domicile), they have spread throughout Europe. Today, many Roma living in our country practice trades they inherited from 
their ancestors: they make pots (căldărari), they process gold (zlatari), they put on shows with bears (ursari), etc.

Nowadays, the Roma have become sedentary, adopting the language and culture of the nation in which they have integrated, although many still speak the Romani language."

(History, Aramis, 4th grade, p. 42)

To bring the data into perspective, a similar albeit less detailed analysis was performed for the Hungarian minority, limited to the 4th grade textbooks. As can be seen from the table below, the number of references for Roma is significantly lower than those for "maghiar". A caveat here is that Hungarians had a history of living in Transylvania as part of an empire. Considering this limitation, the references to the Hungarian ethnicity are still more recurrent than what the subject matter would imply:

Table no. 3. Number of references for Rom and Maghiar in primary school textbooks

\begin{tabular}{|l|c|c|}
\hline & Rom / igan & Maghiar/Ungur \\
\hline No. of occurences & 20 & 72 \\
\hline
\end{tabular}

\subsection{Extent of references}

We have distinguished between instances where Roma appear as a word in a sentence, a short paragraph and a long paragraph.

In the first category we include:

1) 16 one word references, mainly for the purpose of enumerating the national minorities in the country (Geography, 4th grade, Intuitext, p. 26, p. 55; Geography, 4th grade, Aramis, pp. 50-51; Geography, 4th grade, Arthur, p. 54; History, 4th grade, Aramis, p. 41; History, 4th grade, Corint Educational, p. 45; Civic Education, 4th grade, Aramis, p. 16; Civic Education, 4th grade, CD press, p. 23; Social Ed., 6th grade, EDP, p. 24, p. 43; Social Ed., 5th grade, Litera, p. 37), their celebration date (Social Ed., 6th grade, EDP, p. 43; Romanian Language, 5th grade, Litera, p. 91), minorities festivals (Social Ed., 6th grade, EDP, p. 41). 
2) one reference to dance (Music and movement, 4th grade, Aramis, 2nd part, p. 51).

3) 4 references related to school activities/ projects regarding the Roma (Romanian Language, 5th grade, Litera, p. 97; Social Ed., 5th grade, Litera, p. 31, p. 32; Social Ed., 5th grade, Aramis, p. 59).

In the second category, which comprises short paragraphs and short texts, each of which includes at least one occurrence of the relevant terms, we include:

1) 21 fragments tackling discrimination, stereotypes and racial issues (Social Ed., 5th grade, Ascedia design, p. 72, p. 95); (Social Ed., 5th grade, Litera, p. 30; Social Ed., 5th grade Litera, p. 32, p. 77); (Social Ed., 5th grade, Cd press, p. 33, p. 47, p. 74, p. 62); (Social Ed., 5th grade, Aramis, p. 13, p. 61, p. 62; Social Ed., 6th grade, EDP, pp. 43-44).

2) Short texts concerning social, economic condition of Roma students (Social Ed., 5th grade, Litera, p. 31), reasons for dropout; economic deprivation, child abuse (Social Ed., 5th grade, Litera, p. 74).

3) Short text concerning Roma history, culture (History, 4th grade, Aramis, p. 42).

On the other hand, references to Hungarian are usually whole paragraphs, even an entire page is dedicated to Hungarian historical personalities (History, 4th grade, Corint Ed., p. 42).

The relatively significant number or references to minorities suggest that the topics are salient in the textbook authors' perspective. However, this interest does not extend to the Roma minority, despite its comparable population to the Hungarians.

4.3. Character of the references: positive, neutral, negative

The character of the references refers to the positive or negative meaning of a context referring to Roma. The positive references are associated with cultural, historical information about the Roma. For example, a note that informs students that 8 of April marks the International Romani day (Social Education, 6th grade, EDP, p. 43). Another positive example is the case of 
the textbook which discourages students to use the pejorative term igan (Romanian Language, 5th grade, Litera).

In the neutral category, we have included one word references which have little value and school activities targeted to combat stereotypes and discrimination against the Roma, as they imagine a desired order of society. References with a negative impact are as follows:

1) 9 contexts which use the term $\operatorname{igan}(i)$;

2) exercises/ classroom activities where the topic of discrimination is introduced, without being explicitly discouraged. For example, one Social Education textbook proposes a role play activity in which students are asked to imagine they are a 14 year old illiterate Roma girl. (Social Education, 6th grade, EDP, p. 43).

Table 4 comprises 4 positive references, 57 neutral references and 15 negative references.

Table no. 4. Character of reference by grade and subject

\begin{tabular}{|c|c|c|c|c|c|c|c|c|c|}
\hline \multirow{2}{*}{ Textbook } & \multicolumn{3}{|c|}{ 4th grade } & \multicolumn{3}{|c|}{5 th grade } & \multicolumn{3}{|c|}{ 6th grade } \\
\hline & Positive & Neutral & Negative & Positive & Neutral & Negative & Positive & Neutral & Negative \\
\hline $\begin{array}{l}\text { Language and } \\
\text { Communication }\end{array}$ & & & & 2 & 2 & 6 & & & \\
\hline Social Education & & 2 & & & 35 & 1 & 1 & 6 & 3 \\
\hline History & & 5 & 4 & & & & & & \\
\hline Geography & 1 & 7 & & & & & & & \\
\hline Music & & & 1 & & & & & & \\
\hline Total & 1 & 14 & 5 & 2 & 37 & 7 & 1 & 6 & 3 \\
\hline
\end{tabular}

\subsection{Manner of description}

The imagine of the Roma is comprised of simple, yet harsh notes, which can strengthen stereotypes and confirm racialized narratives. There is very little information about the present life, the culture, the diversity within the Roma groups. Textbooks offer limited information which concerns: the presence of the group among other minorities, the Indian origin, the nomadic past, some traditional occupations, few remarks on the Romani language. 


\subsection{Absent history}

Historical accounts about the relationships between the Romanian majority and the Roma minority are ignored, even when these are key elements for the comprehension of a text (Romanian Language, 5th grade, Litera). Even when storylines characters are Roma slaves (Vasile Porojan), the context of Roma slavery in Romania is ignored. The enslaving of Roma people which lasted for five centuries created a specific power dynamic between ethnicities and was part to the formation of the Romanian identity, in which oppression against specific groups became hegemonic:

"Forces of domination were generated during the emergence of a panRomania social formation, creating conditions of prejudice that became hegemonic. This form of cultural domination stereotyped ethnicities as natural or biologically determined cultural, social and economic proclivities of certain groups. In this sense, Gypsies came to be seen as universally marginal sub-humans."

(Beck, 1989, p. 54)

Textbooks do little to repel the stereotyping of Roma, choosing the discourse of the absence. However, the cultural contribution of the Roma groups cannot be ignored. During the long period of slavery, the Roma were driven to specific roles within the Romanian society, contributing to the economic and cultural life. The Roma were craftsmen, iron smiths, cooks, they produced music, embroidery (Beck, 1989). Nonetheless, the cultural domination of the Roma assigned them a parallel cultural road which is devalued, just as the Roma slaves were de-humanized.

This domination is seen even in the choice of words which designate Roma groups. Although more than 100 years ago, in 1919, the Roma communities in Romania, at the meeting in Ibasfalau/ Dumbraveni, in Transylvania, have militated for eliminating the derogatory term igan from official documents, the word is still present in students' textbooks:

"As children and citizens of the great Romanian nation, not wanting to be considered foreigners in a foreign country, as we have been considered for centuries, please: from here on, in all official Romanian documents, the naming (nickname) of 'igan' shall no longer be used to ridicule us and our descendants. “" 
Some textbooks use both words (Romanian Language, 5th grade, Litera), and a single instance was found that discourages students to use the form igan(i). The selection of the words is neither justified, nor presented as substantial. Until recently (2012), the Romanian Language Dictionary considered the words rom and igan as synonyms, with the word igan also encompassing a pejorative meaning: person with bad habits. At one point, igan included the sense slave (Achim, 1998, p. 33). At the initiative of NGOs, the definition of the word igan was changed in 2011, so that the offensive connotation is now clear (Annual Report, Agen ia Împreună, p. 25).

Evidently, this linguistic battle, an incontestable evidence of the oppression the Roma have experienced, is yet to be reflected into textbooks approved by the Ministry of Education.

Social Education textbooks (5th and 6th grades) discuss the issues of discrimination, racial stereotypes and have the potential to enable critical thinking strategies through the real-life events they embody. These contexts usually portray Roma children being rejected, victimized, punished, abused by their Romanian colleagues, friends, neighbors or even their parents for being Roma. It is in the teacher's power to appropriately tackle such sensitive situations and to encourage tolerance, acceptance and empathy. However, the decision to rely mainly on teacher's classroom contribution in order to combat discrimination can become oppressive as such. A recent research led by University Babeş Bolyai (Bădescu et al., 2018) revealed that one in seven teachers think Roma students ought to be separated from other ethnicities. Moreover, almost half of the teachers in favor of segregation support it for the benefit of Romanian students, as "Roma students' behavior would make teaching difficult for the rest of the students" (idem, p. 17).

The cited study found that for Romanian teachers, Roma are the third most undesirable group to have as neighbors, after drug addicts and alcoholics more than $40 \%$ of questioned teachers don't want to be neighbors with Roma people (idem, p. 8). This preference is associated with harsh schooling conditions - poor safety, the presence of children from vulnerable groups, poor exam results, bad management (idem, p. 18).

With respect to the interaction between Roma groups and other ethnicities, 
textbooks present very little information. The interactions between the Roma and the Romanians are sources of critical engagement with race issues and are based on fictional events which tackle rejection, domination. Only one picture illustrates a possible communication between people belonging to the two groups. However, the instance suggests a power asymmetry: while the Romanian woman faces the viewer, the Roma woman's face cannot be seen, she is not to be distinguished and treated as an equal person to the other.

\subsection{Minorities' personalities}

While every History textbook for Primary school develops at least one activity concerning people representing minorities, there is no Roma personality depicted in any textbook. We consider this absence especially important in the attempt for intercultural education. Roma realities are invisible, they do not penetrate the dominant culture.

On the other hand, Hungarian personalities can be seen in many instances. Hungarians are inventors - Rubik's cube and the pen were invented by two Hungarians, László Biró and Ernö Rubik (History, 4th grade, Corint, p. 29), military leaders and kings - Tuhutum (History, 4th grade, Corint, p. 42), Matei Corvin (History, 4th grade, Corint, p. 55) and the brilliant ruler Gabriel Bethlen (History, 4th grade, Corint, p. 60), chroniclers writing about injustice such as Ludovic Tubero (History, 4th grade, Corint, p. 59), writers and scientists like János Apáczai Csere (History, 4th grade, Corint, p. 60). Even more, the Hungarian language is described as a language of culture and great achievements in many fields:

"In the Hungarian language, valuable literary works have been written by great cultural people like Sándor Pëtofi, Ady Endre or Imre Kertész.

The Hungarian people gave the world great scholars and scientists, mathematicians and renowned doctors, but also artists like composers Franz Liszt or Bela Bartók."

(History, 4th grade, Corint, p. 28)

Roma people who could represent their ethnicity and are successful in Arts, Science, Journalism are not mentioned in primary school textbooks. No other Roma role models are introduced. This absence is significant not only to 
Roma children, but also to their non-Roma peers, as Roma becomes associated with failure. This absence is an evidence of cultural imperialism, an oppression which narrows educational possibilities; one cannot see behind the cage one is locked into (Frye, 1983).

\subsection{Roma characters in storylines}

Three literary pieces illustrate stories with Roma characters. The most frequent story present in two Romanian Language textbooks (Romanian Language, 5th grade, Aramis, p. 76; Romanian Language, 5th grade, Litera, p. 90) and one Social Education textbook (Social Ed., 5th grade, CdPress, p. 76), Vasile Porojan, is the story of a friendship between a Romanian boy and a igan. Textbooks guide the reading-comprehension differently, either ignoring the racial dimension of the text (Aramis) or exploring the racial theme in depths (Litera). A major contribution in the comprehension process is made through illustrations, which influence the first interaction with the text. One illustration (Romanian Language, 5th grade, Aramis, p. 76) presents the two boys at the first page of the text, running happily and smiling. The differences between them are strongly emphasized through clothing, shoes, color of hair. The Romanian boy is carefully dressed in a clean, traditional white blouse, and smiling while gazing at the sun. On the contrary, at the bottom of the page there lies the figure of the Roma which is created through darker tones, his skin is brown, his hair disheveled, while his clothes are too small and unkempt. The Roma has no shoes and runs bare feet on the ground. He does not look at the sun, but, symbolically, he looks up at the Romanian boy.

When the reading-comprehension strategies focus on the racial theme (Romanian Language, 5th grade, Litera, pp. 90-92), the discourse reveals contradictory attitudes. While the title of the lesson pleads for equality (Beyond social / ethnic differences), for a perspective in which differences could be abolished, the authors' choice for guiding the comprehension has significant flaws. First of all, there is a significant lack of coherent information about the status of the Roma in the past. While the text slightly points out issues of liberty, the comprehension process ignores the reality of slavery. Vasile Porojan was a slave, as many Roma people still were in 
the nineteenth century in Romania. However, the textbook only uses the word $r o b$ which has a double meaning in Romanian, one of them being laborer, thus the textbook allows a degree of confusion. Moreover, the term Rom is never mentioned in referring to the main character, the textbook uses the word igănesc, while discouraging students to use the word igan.

Second, some textbook activities devalue the Roma people by delimiting the spaces they can occupy in society - asking students to place the Romanian and the Roma on an imaginary scale of values (Romanian Language, 5th grade, Litera, p 91). Third, the power asymmetry is validated through the absence of historical information about the living conditions of Roma in the past. The Roma inferior status is presumed, allowed and never contested. The reading comprehension strategies envisage a reality in which the Roma is bound to the lower levels of societies as opposed to his wealthy Romanian friend. The authors choose the sentence He had a brilliant social career (idem, p. 92) in reference to the non-Roma child and the sentence He could not hope for any social achievement due to ethnicity (ibidem) for the Roma child. Ethnicity becomes an unsurmountable confinement.

However, literary pieces must not be treated as mere fictional instances, as through children's books, children shape their thinking about themselves, their peers and society, they sense what is expected from them and they gradually develop modes of thinking and behaving that suit their constructed roles as boys or girls, disabled or non-disabled children, children from ethnic minority groups or children from the dominant culture (Monoyiou \& Symeonidou, 2016). Vasile Porojan is written in the form of a letter which emulates veracity and creates the impression of reality. The realism stimulates a deeper connection with characters.

Reading is transactional (Morrisson \& Wlodarczyk, 2009, p. 111), a continuous negotiation between text and reader, always dependent on a social interaction. Furthermore, "focusing on a figure that is considered different from the dominant group" has the potential to perpetuate "the gap between the dominant characters of a given culture and the perceived Others".

The second text with a Roma character (Romanian Language, 5th grade, 
Art, pp. 159-160) is an ethnic story presented alongside other stories of different origins in a multicultural class reading activity.

\section{Discussion and conclusions}

While the new syllabi for primary and middle school plead for diversity, tolerance and an interest for intercultural education, textbooks fail to put in practice these principles, thus allowing the reproduction of stereotypes and negative attitudes towards the Roma groups. Most significant is the absence of Roma related events, personalities, historical facts. It is relevant to note that, while all 4th grade History textbooks have a chapter dedicated to minorities personalities, no Roma personality is presented or discussed. The only Roma figure present in Romanian textbooks is a successful football player, Bănel Nicoli ă (Social Ed., 6th grade, EDP, p. 67). By contrast, there is ample space dedicated to Hungarian historical figures, authors and scholars.

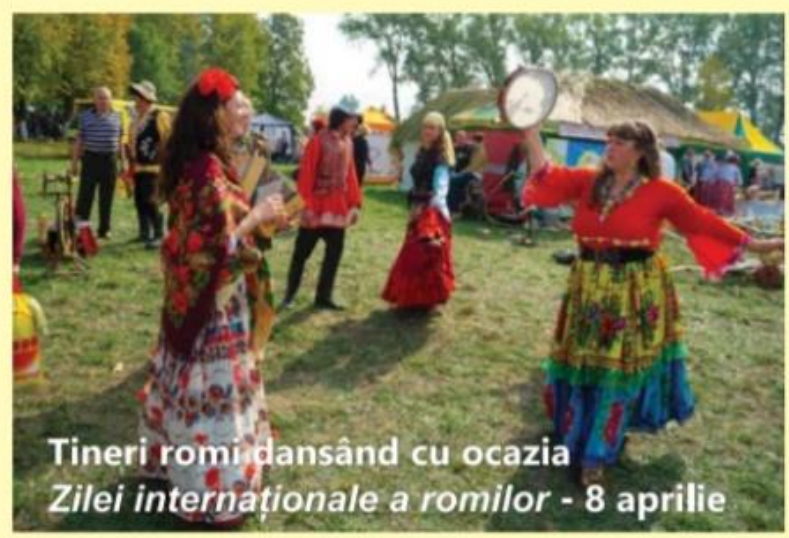

Figure no. 1. Roma young people dancing while celebrating the International Romani Day - 8 April, EDP, Social Education, 6th grade

The Roma appear to have no contribution on the development of the country in any field, as their presence in textbooks is rather ghostly, usually achieved through pictures. The most prevailing illustration (Figure no. 1) shows Roma 
people dressed in traditional clothing, dancing on grass, celebrating, living a leisurely life.

A more realistic perspective is pointed out by Social Education textbooks which allow a glimpse on the conditions faced by many Roma students. A few instances present Roma children as theoretically equals to their Romanian peers, but the social context in which they find themselves limits and reduces their ability to thrive.

In order to reduce the oppression through cultural imperialism, we propose Nancy Fraser's (1995) framework on social justice. One strategy to reduce injustice consists of affirmative remedies which are "aimed at correcting inequitable outcomes of social arrangements without disturbing the underlying framework that generates them" (Fraser, 1995, p. 82). This type of remedy implies that students are rational agents, they learn what they are being told and internalize the rules, which is a contested idea. Some authors suggest an approach that "teaches" rather than "preaches", a strategy of deconstruction and reconstruction since "adolescents do not like to be told" what to do and how to behave (Kenway \& Fitzclarence, 1997, p. 127). Students should be treated as "agents of rather than passive recipient of" reforms (ibidem).

Concentrating on textbooks can leave out a key component of the curriculum, the teachers, as they interpret the textbooks themselves and create local and original discussions in the classrooms. Teachers need adequate guidelines and formation to effectively teach such sensitive matters. Roma realities, lives, personalities, history ought to be integrated in classroom discussions, as well as elements of culture, story lines, traditions. These contents have the potential to reduce the marginalization of Roma students and alleviate the stigma, by raising awareness about Roma groups' present and past, their cultural richness, their essential contribution to the formation of the Romanian identity. Reading literary texts which present credible characters can "empower both children from ethnic minority groups and children from the dominant culture to understand the complicated nature of human experiences" (Monoyiou \& Symeonidou, 2016, p. 2). As long as the text does not solely emphasize the victim and is not centered on the powerlessness and marginalization of the racially marked individual (Rogers \& Christian, 
2007) but questions the "ideology" of "the master", it can be a valuable piece of work in addressing racial interactions.

Through a position paper, UNICEF recommends creating an inclusive, local curriculum:

"The curriculum needs to be reviewed to ensure that it is inclusive of all children, and all teaching and learning materials are free from harmful or negative representations of Roma communities [...]. The curriculum should include the teaching of Roma language, culture and history."

(UNICEF, 2011, p. 56)

In this paper I have critically analyzed the Romanian alternative textbooks in search for the representation of Roma groups. I have employed Iris Young's conceptualization in the field of social justice to argue that textbooks can become an oppressive tool for the Roma minority. My argument follows two directions. Firstly, using Zacho's framework for content analysis of textbooks, I have analyzed the number of references to Roma people, the extent, the character of references and the manner of description.

Secondly, I have explored the presence or the absence of historical figures and events about the Roma in textbooks. Notably, we have identified very little information about the history of Roma people in Romania. The interactions between the Roma and other groups are presented only for the purpose of introducing themes of discrimination, prejudice and racism. However, textbooks do not address the sensible and intricate historical relationship between the dominant population and the Roma minority - which is vital in understanding the status, the narratives surrounding the Roma in Romania today. References to slavery are very rare and achieved through literary texts adding a sense of dimness. The prejudice against Roma today is approached as a given reality, imprinted in the present, but not within a diachronic approach.

Using a comparative strategy, we have employed similar content analysis instruments on the representation in textbooks of the Hungarian ethnic minority. The data, while less detailed and limited to 4th grade textbooks, suggest a significant difference between the positive attitudes and attention devoted to Hungarian themes compared to the Roma ones, though more research is warranted. 


\section{References}

- Achim, V. (1998). iganii in istoria Romaniei. Editura Enciclopedică.

- Agen ia Împreună. (2012). Annual Report, What have we done together in 2011 ?

- Bădescu, G., Ivan, C., Angi, D., \& Negru-Sub irică, O. (2018). Educa ie pentru democra ie în şcolile din România.

http://library.fes.de/pdf-files/bueros/bukarest/14767.pdf

- Barany, Z. (1994). Living on the Edge: The East European Roma in Postcommunist Politics and Societies. Slavic Review, 53(2), 321-344.

https://doi.org/10.2307/2501296

- Beck, S. (1989). The origins of Gypsy slavery in Romania. Dialectical Anthropology, 14(1), 53-61. https://doi.org/10.1007/BF00255926

- Buzducea, D. (2013). Economia socială a grupurilor vulnerabile. Polirom.

- Crowe, D., \& Kolsti, J. (1991). The Gypsies of Eastern Europe. Sharpe.

- Elleh, N. (2014). Reading the Architecture of Underprivileged Classes. Routledge.

- Fleck, G., \& Rughiniş, C. (Eds.). (2008). Vino mai aproape. Incluziunea şi excluziunea romilor în societatea românească de azi. Human Dynamics.

- Fraser, N. (1995). From Redistribution to Recognition? Dilemmas of Justice in a 'PostSocialist' Age. New Left Review, 212, 68-93.

- Frye, M. (1983). The Politics of Reality. Freedom. Crossing Press.

- Greenberg, J. (2010). Report on Roma education today: from slavery to segregation and beyond. Columbia Law Review, 110(4), 919-1001.

- Holsti, O. R. (1969). Content Analysis for the Social Sciences and Humanities. Addison-Wesley.

- Ivan, C., \& Rostas, I. (2013). Părăsirea timpurie a şcolii - cauze şi efecte. Roma Education Fund Romania.

- Kenway, J., \& Fitzclarence, L. (1997). Masculinity, violence and schooling: Challenging "poisonous pedagogies". Gender and Education, 9, 117-133. https://doi.org/10.1080/09540259721493

- Monoyiou, E., \& Symeonidou, S. (2016). The wonderful world of children's books? Negotiating diversity through children's literature. International Journal of Inclusive Education, 20(6), 588-603. https://doi.org/10.1080/09540259721493

- Morrison, V., \& Wlodarczyk, L. (2009). Revisiting Read-Aloud: Instructional Strategies That Encourage Students' Engagement With Texts. The Reading Teacher, 63(2), 110-118. https://doi.org/10.1598/RT.63.2.2

- Nieto, S., Bode, P., Kang, E., \& Raible, J. (2008). Identity, Community and Diversity: Retheorizing Multiultural Curriculum for the Postmodern Era. In F. 
M. Connelly, M. F. He \& J. A. Phillion (Eds.), The Sage Handbook of Curriculum and Instruction (pp. 176-196). SAGE Publications.

- Petrova, D. (2003). The Roma: Between a Myth and the Future. Social Research, 70(1), 111-161.

- Rogers, R., \& Christian, J. (2007). 'What could I say?’ A critical discourse analysis of the construction of race in children's literature. Race Ethnicity and Education, 10(1), 21-46. https://doi.org/10.1080/13613320601100351

- Ştefănescu, P. (2005). Legal rights and educational policies for ethnic minorities in Romania. Paper presented at the International week. Berlin.

- UNICEF. (2011). The Right of Roma Children to Education: Position Paper. UNICEF Regional Office for Central and Eastern Europe and the Commonwealth of Independent States (CEECIS).

https://www.unicef.org/eca/media/1566/file/Roma\%20education\%20 postition\%20paper.pdf

- Young, I. M. (1990). Justice and the Politics of Difference. Princeton University Press.

- Zachos, D. T. (2017). Roma, Curriculum, and Textbooks: The Case of Greece. Creative Education, 8(10), 1656-1672. https://doi.org/10.4236/ce.2017.810112

The online version of this article can be found at: http://revped.ise.ro/category/2020-en/

\section{(C) $B Y-N C-B A$}

This work is licensed under the Creative Commons Attribution-NonCommercial-ShareAlike 4.0 International License.

To view a copy of this license, visit http://creativecommons.org/licenses/by-nc-sa/4.0/ or send a letter to Creative Commons, PO Box 1866, Mountain View, CA 94042, USA.
Versiunea online a acestui articol poate fi găsită la: http://revped.ise.ro/category/2020-ro/

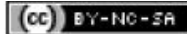

Această lucrare este licen iată sub Creative Commons Attribution-NonCommercial-ShareAlike 4.0 International License.

Pentru a vedea o copie a acestei licen e, vizita $i$ http://creativecommons.org/licenses/by-nc-sa/4.0/ sau trimite i o scrisoare către Creative Commons, PO Box 1866, Mountain View, CA 94042, SUA. 


\title{
WALKING THE TIGHTROPE: CHALLENGES ENCOUNTERED IN NOVICE TEACHERS' PRACTICE
}

\author{
Miruna Luana Miulescu* \\ National Center for Policy and Evaluation in Education, \\ Education Research Unit, \\ Bucharest, Romania \\ miruna.miulescu@gmail.com
}

\begin{abstract}
The first years of teaching experience are crucial for beginning teachers as they face numerous challenges. Moreover, the way novices succeed in handling challenges during their first year of field work is a key determinant of their decision to continue working in the system or not. In this respect, a notable theme within the literature considers the experiences and challenges of beginning professionals, as more and more researchers talk about the "praxis shock", "reality shock" or "transition shock" to better depict the process through which new teachers pass in order to get accustomed to their new professional context. Our study seeks to investigate the challenging experiences that novice kindergarten teachers encounter, as well as the strategies they adopt in order to overcome them. The participants of the present study are beginning teachers $(n=16)$ with a maximum of three years' teaching experience from six public inner-city kindergartens. By making use of a phenomenological qualitative inquiry, data was collected through participating at semi-structured interviews, focus groups and by filling in logbooks. After the data was recorded and transcribed, five main themes were identified. The key findings indicate that a new professional context can often lead to uncertainty and discomfort. Moreover, beginning teachers' "challenging moments" descriptions generally emphasize their struggles concerning their own professional development, the school organizational aspects, as well as their relationships with students, colleagues, principals and parents. The results of the study show the need to restructure the collaboration process between novices and kindergartens, in order to improve
\end{abstract}

* Researcher, PhD, National Center for Policy and Evaluation in Education (NCPEE), Education Research Unit, Bucharest, Romania. 
collaborative relationships and provide the appropriate context for the professional development of kindergarten teachers at the beginning of their careers.

Keywords: challenging experiences, novice teachers, qualitative study, teacher education.

\section{Rezumat}

Primii ani de experien ă didactică sunt cruciali pentru profesorii începători, deoarece aceştia se confruntă cu numeroase provocări. Mai mult decât atât, modul în care debutan ii reuşesc să gestioneze provocările în primul lor an de muncă este un factor cheie în ceea ce priveşte decizia lor de a continua să lucreze în sistem. În acest sens, o temă importantă din literatura de specialitate explorează experien ele şi provocările educatorilor debutan $i$, întrucât tot mai mul $i$ cercetători vorbesc despre „şocul practicii”, „şocul realită ii” sau „şocul de tranzi ie" pentru a descrie mai bine procesul pe care noii profesori îl parcurg pentru a se obişnui cu noul lor context profesional. Studiul nostru investighează experien ele solicitante pe care le întâmpină profesorii începători din grădini ă, precum şi strategiile adoptate pentru a le depăşi. Participan ii studiului sunt cadre didactice debutante $(n=16)$ cu o experien a de predare de maximum trei ani, din şase grădini e de stat. In cadrul unei investiga ii calitative de tip fenomenologic, datele au fost colectate prin interviuri semi-structurate, focus grupuri şi prin analiza jurnalelor completate de participan ii la studiu. După prelucrarea şi analiza datelor, au fost identificate cinci teme principale. Cele mai importante constatări indică faptul că un nou context profesional poate duce adesea la incertitudine şi disconfort. Mai mult, descrierile „momentelor provocatoare" ale debutan ilor se referă, în general, la experien e legate de propria lor dezvoltare profesională, aspecte organizatorice, precum şi rela iile cu elevii, colegii, managerii şcolari şi părin ii. Rezultatele studiului arată necesitatea restructurării procesului de colaborare între debutan $i$ şi grădini e, în vederea imbunătă irii raporturilor de colaborare şi oferirii contextului adecvat pentru dezvoltarea profesională a educatorilor afla i la început de carieră.

Cuvinte-cheie: experien e solicitante, formarea profesorilor, profesori debutan $i$, studiu calitativ. 


\section{Introduction}

The successful retention of teachers has been on the international agenda for many years (OECD, 2005). A great deal of research has been dedicated to studying the effects of teachers' practices on student achievement (Darling-Hammond, 2014; Goe, 2007; Hattie, 2009) and consistent evidence suggests that teacher effectiveness actually contributes a great deal to student learning (Blömeke et al., 2016; Kunter et al., 2013). Evidences of both qualitative and quantitative analyses indicate that quality of teachers is undoubtedly the strongest correlate in student performance enhancement (Darling-Hammond, 2014).

Nevertheless, in spite of strong evidence that teacher quality is key to student success, there is no general agreement on which teacher characteristics have a significant contribution to student learning outcomes (Hattie, 2009; Rivkin et al., 2005; Scheerens, 2016). Student achievement has been linked to diverse factors from teacher's personal characteristics, such as verbal intelligence, self-efficacy and locus of control (Scheerens, 2016) to attributes which refer to professional's years of teaching experience, certification status or educational background (Darling-Hammond, 2000, 2014; Goe, 2007). Nonetheless, research which connects the educator's attributes to pupils' learning results is still relatively scarce.

In the context of quality teaching and learning, the current policy debate is focused on hiring and retention of teachers with major emphasis on professionals working with kindergarten children, as early childhood education plays a paramount role in children's development, learning, and well-being (OECD, 2019). It is a well-known fact that the first few years are decisive for teacher retention, as high quality professionals are expected to exit the system due to diverse factors. The body of literature which addresses why teachers leave the profession attributes the following reasons to the unsuccessful retention process, apart from personal reasons: lack of administrative support (Liu \& Meyer, 2005; Tye \& O’Brien, 2002), weakly organized or insufficient mentoring (Gratch, 1998), low salary (Tye \& O’Brien, 2002) or accountability issues (Darling-Hammond \& Sykes, 2003). 
In the present study, we will investigate in-depth the challenging experiences that novice teachers encounter during their work in kindergarten, as well as the strategies adopted in order to overcome them.

\section{Literature review}

The way novice teachers succeed in handling challenges in their first year of field work is a key determinant of their decision to continue working in the system or not (Sözen, 2018).

In this respect, a notable theme within the literature considers the experiences and challenges of beginning professionals. Kelchtermans and Ballet (2002) take notice of the "praxis shock" endured by novices when entering the new profession. On a similar note, Gordon and Maxey (2000) talk about "reality shock", and Corcoran (1981) refers to the "transition shock" to better depict the process through which new teachers pass in order to get accustomed to their new professional context.

Learning the ropes requires great effort on the novice's part, as he/she struggles with getting to know the students and learning the school's policies and procedures. Contrary to popular beliefs on the teacher's roles, beginning teachers spend a large amount of time on classroom management and administrative issues and less on teaching and learning (OECD, 2005). Being a teacher involves multiple and demanding tasks that most of them had not been adequately prepared for in their pre-service training (Nieme, 2002). Therefore, their expectations are not met and often frustration takes control. In addition, a newly graduate teacher cannot have the same competences as an experienced one. In spite of this, research shows that beginning professionals are expected to perform like their more experienced colleagues (Smith \& Sela, 2005); for instance, it is expected from them to handle the same workload as their more qualified fellow teachers, implement classroom activities efficiently, contribute substantially to their students' development progress, contribute to school development, etc.

The first years of teaching experience are crucial for beginning teachers as they face numerous challenges. According to prior research, novices need 
to find strategies to adapt to a new professional environment, interact with their colleagues, their students and their students' parents, efficiently organize their time, manage their class, organize their lessons, etc. (Çakmak et al., 2018).

Taking into account that they find themselves in unfamiliar conditions in which immediate decisions are required, it is imperative to find customized solutions to every particular problem which arises in practice. But their situation is not to their advantage: they have limited repertoires gained during pre-service practicum which translates to a lack of relevant experience to successfully cope with all the challenges. They often rely on their competences developed through their pre-service teacher training programme, but most of the time those are just not enough.

The educational literature of recent years is rich in scientific attempts to explore the complex process through which beginning teachers pass in order to successfully meet work demands. An expansion of interest has specifically been given to investigating newly qualified teachers' experiences related to stressful work contexts (McCann \& Johannessen, 2004; Veenman, 1984). Due to the nature of the topic, most of the studies deployed qualitativefocused research. For instance, McCann, Johannessen and Ricca (2005) analyze through structured interviews the challenges beginning teachers face, as well as their coping strategies. In their research, data shows that there are major categories that lead to novices' concern: relational problems (with students and their parents, fellow workers and supervisors); understanding of subject/curriculum, workload; evaluation of students' performances; autonomy and authority; appearance and teacher identity. As part of the research, the authors advance some possible solutions to the problems they are confronted with: carefully designed mentoring programs, the expanding of the network of teacher contacts or realistic teaching assignments.

On a similar note, Aarts, Kools and Schildwacht (2019) discuss the complex difficulties graduates experience in their first years of teaching. The researchers conducted a study on 35 secondary school teachers in their first and second year of employment. Even though the results show a shift in their challenges between the less experienced group and the more experienced one (one year apart), their major tension is attributed to the teaching process 
itself. More specifically, early-career teachers are confronted mainly with choosing the best teaching strategies for their students, concentrating on student's learning process, objectively assessing students' performances, efficiently managing the group of students or combating discipline issues. Other areas of tension for novices are related to workload and organizational aspects of the school (i.e., multitude of non-teaching tasks).

Pillen, Beijaard and den Brok (2013) carried out a study with the aim of assessing 141 novice teachers' daily uplifts and hassles, as well as their well-being. By using a diary method, the researchers gained a deeper understanding of the work-related stressors in the early-graduates' transition to their profession. Data shows that daily stressful moments are related to the teaching process and relation with other colleagues. At the same time, the study investigates the uplifting moments, which bring satisfaction to beginning teachers, as compared to other studies which direct their attention to the negative picture of the novices' professional life.

The complex nature of teaching was also depicted in a study conducted by Britt (1997) in which she investigates the new teachers' perceptions of their first teaching experiences. The findings show that these experiences are not all positive, many new graduates facing stress as they try to navigate the new work context. The problematic aspects perceived by novices fall into the following themes: class and school discipline, time management, preparation for lessons and parental involvement.

\section{Methodology}

As we already stated, this study's main objectives are to explore the challenging experiences that novice teachers encounter during their work in kindergarten, as well as the strategies adopted in order to overcome them. In this direction, we will discuss the meaning of these experiences and its significance in the process of building their professional identity. To accomplish this aim, the study is designed as a phenomenological qualitative inquiry. The phenomenology design was chosen because the focus is on comprehensively understanding the participants' experiences on a particular phenomenon. The particular phenomenon under study is explored through 
collecting data (qualitative methods) and discovering commonalities between the participants' perceptions (Marshall \& Rossman, 2011). Thus, the phenomenological design contributes to the real-life experiences of novice teachers about challenging experiences in public kindergartens in the Romanian educational system.

\subsection{Research participants}

In the case of beginning teachers, the person who is not yet experienced in teaching is called "novice". Although this term refers to a professional who is just at the start of his/her teaching career, there are still debates on whether this stage lasts for one, two or five - year period. For instance, according to Haynes (2011), teachers cease to be called novices after two or less years of teaching experience. Contrary to this opinion, Kim and Roth (2011) argue that newly qualified teachers can be called this way up to five years of field work. Another relevant study (Davis et al., 2006) defines a beginning teacher as pre-service professionals as well as those in their first year of work. Even though the literature defines distinct novice teacher profiles, for the purpose of this paper, beginning teachers are considered the professionals who have been working for less than 3 years.

In the present study, the participants were selected based on availability (or convenience sampling; i.e. collecting samples that are conveniently located and willing to be involved in the study) (Teddlie \& Yu, 2007). As Patton (2002) pointed out, convenience sampling is extensively used in qualitative research for analyzing cases that can yield richness of information related to the phenomenon of interest. Therefore, the selection of participants resorted to a convenience sample of individuals, and was based on certain criteria, such as: professional experience of a maximum of three years of teaching experience, teaching the same age group (teaching in kindergarten), recently completed Bachelor degree studies in Pre-School and Primary Educational Pedagogy, as well as availability and eagerness to participate.

The participants of this study are novice teachers $(n=16)$ meeting the above written criteria, alumna of the Pre-School and Primary Educational Pedagogy programme in the Faculty of Psychology and Educational Sciences, 
part of the University of Bucharest in Romania. Moreover, they are between ages of 22 and 31 years old, and work in similar contexts (6 inner-city kindergartens).

In the first phase of the sampling process, we contacted 28 novice teachers and gave them an extensive explanation of their future involvement in the research process. Only 16 of them agreed to take part in the study. The fact that almost half of the initial group decided to be out can be explained by the demands of keeping record of various experiences in a logbook. The logbook serves to keep record of important events and must be filled in daily for two weeks. It seems that this was the main constraint as perceived by the beginning teachers.

\subsection{Data Collection}

Since data gathering process is an essential part of a research, careful consideration had been given to developing data collection procedures, choosing the most suitable methods to gather qualitative information on specific variables and building a robust monitoring strategy of the entire process. Specifically, novice teachers were requested to use logbooks for the first two weeks of their practice in kindergarten. The participants had to write in the logbook on a daily basis about their most challenging experiences during their teaching. This autobiographical tool was not filled in thoroughly with their field experiences by all teachers, the reason being its timeconsuming nature. Therefore, because this technique did not work out as expected, two other qualitative instruments were employed in order for the teachers to elaborate on their field experiences: semi-structured interviews (with the 5 teachers who did not successfully complete the logbooks) and focus groups (3 focus groups which involved all participants).

The logbook was selected as a methodological tool so the teachers could describe their subjective perception of challenging moments in their teaching. As evidenced by numerous authors (Clemente et al., 2017; Romano, 2005), this narrative tool has descriptive purposes through which the researcher can explore and better understand the person's experiences about a phenomenon. 
Prior to this research, a study employing the phenomenological approach was conducted by Romano (2005), in which she explored "bumpy moments" in teacher education as a way to analyse pre-service teachers' understandings of their teaching experiences. In our study, the investigative tools (logbook, interview and focus group) were designed based on the methodological instruments developed through Romano's study. The logbook and interview items were the following:

(1) Please describe the challenging experiences you encountered during your teaching.

(2) How did you deal with it?

(3) Did you need anyone's help in handling it?

(4) Do you feel you have learned something from this experience? Please elaborate on your answer.

The semi-structured interview was chosen as a data gathering instrument as it is one of the most applied tools for generating information in educational research and gaining insight into people's thoughts and experiences (Denscombe, 2010). The focus group was selected as an appropriate methodological tool in the context of the present study based on its potential to elicit information and view sharing between participants in a short period of time (Kuckartz \& Rädiker, 2019). The semi-structured interviews and focus groups lasted approximately 20-30 minutes and 60-70 minutes, respectively. The teachers agreed to be audiotaped for a further analysis of their answers.

\subsection{Data analysis}

The logbook, interview and focus group data were analysed using qualitative content analysis (Bernard \& Ryan, 2010; Strauss \& Corbin, 1990) in order to delve more into the data. The data was transcribed verbatim and then analysed. The first phase consisted of identifying codes, then the codes were divided into different 15 categories across the data. Finally, these were listed under five main themes: 
Table no. 1. Teacher challenges - Coding Scheme

\begin{tabular}{|l|l|}
\hline Theme & Category \\
\hline The teacher & $\begin{array}{l}\text { Professional autonomy } \\
\text { Professional identity }\end{array}$ \\
\hline \multirow{3}{*}{ School organization } & $\begin{array}{l}\text { Workload } \\
\text { Bureaucracy } \\
\text { Teaching commitments } \\
\text { School and classroom resources }\end{array}$ \\
\hline \multirow{3}{*}{ Relationships with students } & $\begin{array}{l}\text { Motivating students } \\
\text { Individual differences } \\
\text { Classroom management } \\
\text { Dealing with undisciplined students }\end{array}$ \\
\hline \multirow{2}{*}{ Relationships with colleagues and principals } & $\begin{array}{l}\text { Collaboration with other teachers, } \\
\text { principal, other kindergarten workers } \\
\text { Feedback and guidance } \\
\text { Mentoring }\end{array}$ \\
\hline \multirow{2}{*}{ Relationships with parents } & $\begin{array}{l}\text { Interaction with parents/child's family } \\
\text { Parents' involvement in kindergarten } \\
\text { activities }\end{array}$ \\
\hline
\end{tabular}

\section{Findings}

\subsection{The teacher - identity and autonomy}

Veenman (1984) explains that the first-year experience of teaching can be "a dramatic and traumatic one" (p. 143), as most novices experience the transition from initial teacher training period to teaching profession with emotional distress and many struggles. The wide-ranging demands are also reflected in the category concerning the teacher's identity and autonomy. During the last few decades, the teacher's professional identity has become a prominent area of research (Beauchamp \& Thomas, 2009; Olsen, 2010), as it can be used as a resource for researchers to analyze teacher's learning and development.

In our study, reality shows that all beginners had experienced tensions regarding their professional identity. Most of them characterized the first few weeks of kindergarten as a "struggle". As the shift between faculty and workplace is a very dynamic and complex process, the novice is often in the situation where she/he has to count on the others' experiences and advice or their own (from practicum period). The tensions are caused when all these sources are experienced as conflicting or clashing. 
Researchers have agreed that tensions can have a considerable significance in professional identity development, as stressful experiences force the novice to question his/her own beliefs and practices (Alsup, 2006; Olsen, 2010). Nevertheless, some experiences could lead to profound emotional consequences for their development and functioning, as a novice explained:

"I feel at a loss right now because I was taught in a, let's say, constructivist teaching approach, and in my kindergarten, my mentor has a very traditional approach. I just feel it isn't right. I know it because the children are not happy, are not satisfied. I am afraid I will become like the teacher I had when I was young." (Participant with 2-years teaching experience)

Teacher autonomy is perceived as a pivotal element in quality teaching and learning (Huang et al., 2019). Researchers stress the importance of teacher autonomy, since a sense of powerlessness among newly qualified teachers could potentially lead to stress and anxiety (Aoki, 2002; Billett, 2001). In terms of describing the autonomous teacher, different views can be identified, the most prominent being the one belonging to Gabryś-Barker (2017): "fully competent, motivated by having a calling and a positive attitude to his or her students, which allows him or her to facilitate the learning process by creating a favorable classroom atmosphere" (p.175).

In our study, the majority of newly graduates (13 out of 16) have emphasized their struggles regarding the need to keep a balance between their work in the classroom and the organizational aspects of the kindergarten. Not surprisingly, many have confessed that they find all the demands confusing: "There are so many tasks every single day and I always leave the kindergarten drained of my energy. And I find perplexing that there are more and more tasks (not all concerning my class)." (Participant with 1-year teaching experience)

\subsection{School organization}

All novice teachers reported that bureaucracy represents a major constraint on their teaching-related assignments. Moreover, factors such as workload and limited amount of time cause many beginning teachers to feel a sense of unfulfillment. Such situations could lead to weakened morale and job dissatisfaction, as some participants have reported: 
"I feel taken aback by all the assignments that are not related to teaching. I really wanted to be a teacher, but these days I really struggle with motivating myself to go to work." (Participant with 1-year teaching experience)

In line with our findings, other studies (Butt \& Lance, 2005; Naylor \& White, 2010) also confirm that all teachers, irrespective of their seniority, are assigned complex tasks, many unrelated to teaching. Some study participants even described that at the end of the day, during their personal time, they still have to keep up with the demands and this interferes with their family time:

"In trying to fulfill all my work responsibilities, I find it very hard to keep a balance between my work and my private life. Needless to say that some parents call me on weekends... I know that I am their children's teacher and I have a huge contribution to their development, but this is just too much." (Participant with 2-years teaching experience)

\subsection{Relationships with students}

Novices found it challenging when they dealt with individual differences among students. This was a pervasive mentioned problem, as all the teachers found it difficult to cope with. Addressing the needs of a diverse student population is a challenge even for experienced teachers, but sometimes early-graduates are expected to take on special needs students since their first day of kindergarten.

"I have 2 children with special education needs in my class. One is diagnosed with Asperger syndrome and the other with ADHD. Sometimes it is really difficult for me to handle a class of 20 fiveyear olds." (Participant with 1-year teaching experience)

In order to successfully manage this kind of situation, beginning teachers make an effort to establish their own strategies, with the help of their colleagues. Some of them even contact their professors at university or former faculty colleagues to get as much professional help as possible:

"From my first year in kindergarten until now I have talked regularly with other former colleagues at faculty and to one of my professors whenever I find myself in a difficult situation." (Participant with 2years teaching experience) 
Another great source of stress is represented by the undisciplined students. Many research participants have highlighted the fact that they are struggling to handle the situations when children misbehave towards the teacher or their colleagues. Discipline issues can be hard to handle, even more so for novices. Also, novices could get frustrated by challenging moments such as the ones where they cannot keep the class quiet. Most of the times, especially when they meet a new group of children, unexperienced teachers find it hard to manage a group of 15-20. One teacher wrote the following in her logbook:

"My first day was chaotic. I did not know where to look, because every time I was getting distracted by a child or a group of children." (Participant with 2-years teaching experience)

In this kind of situation, some novices found help by asking other colleagues for support, reminding themselves the strategies they learned in their initial training or observing how other teachers manage thier own group of children. One teacher explained:

"Seeing that I cannot manage my group properly, I tried to notice how other teachers succeed in handling their classes. I decided that I have to be more firm when I ask them to do something. Also, I have to decide together with the students a set of rules that everyone has to abide by. I need more structure and so do they." (Participant with 2-years teaching experience)

4.4. Relationships with colleagues and principals

New teachers have different needs in comparison to the more-experienced ones. In order to grow professionally, there have to be efficient induction programs in helping newcomers to the kindergarten. Unfortunately, reality shows us that, most of the times, novices persevere and struggle to adjust to the new environment without asking for help. Moreover, they sometimes receive insufficient, inconsistent or no feedback and guidance from colleagues and principals.

"I remember that in my first week I was overwhelmed by everything. I thought of asking my colleagues of better ways of managing the group of children, designing my lessons and communicating with 
parents, but I did not receive any response. [...] It might have been because they were as overwhelmed by activities as much as I were." (Participant with 1-year teaching experience)

Support from colleagues can help newly-graduates in assessing their practices and experiences, as well as help them become more confident in their own career development:

"I remember that in my first year of teaching, one of my colleagues that I greatly respected told me that I should be always asking for help when I find myself lost because it is normal to feel like that in the beginning. With her help, I learned a lot, the mistakes I made." (Participant with 2-years teaching experience)

Encouragement from principals and older colleagues is much appreciated from the novices' part, but constructive feedback is much more valued. New teachers feel the need to learn and improve, and genuine support gives them a sense of confidence in their own practice. As a teacher with one year of teaching experience noted:

"I feel that my principal believes in me and my ideas to improve the lessons. I know that I am just starting to get the hang of it, but it helps a lot to know that someone is willing to answer your questions when you need a trustworthy answer." (Participant with 1-year teaching experience)

\subsection{Relationship with parents}

A major area of dissatisfaction was represented by the problematic relationship with parents and families which covered several aspects. On the one hand, some of the novices complained about the lack of interest on behalf of the parents, as well as the insufficient support for their plans for sustaining the children's learning development. On the other hand, other novices described the challenging situation where some of the parents were overeagerly involved in the classroom life, by imposing their own rules (e.g., special emphasis on order and quiet in the classroom, and best pedagogical practices in their perspective), or displaying an overprotective behavior by staying in class and nursing their child for several hours a day, even though the institutional rules do not allow this. 
Moreover, early graduates reported that some parents placed tremendous pressure on teachers through comments made during kindergarten visits or angry phone calls, this being a result of the lack of trust of parents in the novices' abilities to manage the class and provide valuable learning opportunities for their children.

One of the kindergarten teachers wrote the following in her logbook:

"Teaching is a wonderful profession, but I encountered daily so many difficulties with parents that it is starting to get me annoyed. Lately, parents have been giving me lots of suggestions, and some of them sound ridiculous (e.g., to let his child sit in my lap all day long because he dearly misses his parents, even if this is his child's $2^{\text {nd }}$ year in kindergarten and I have other 18 children to take care of; also, I do not have another colleague with me in class). It is really exhausting. I have never believed it could be this tiring to work with parents." (Participant with 1-year teaching experience)

Failing in consolidating a successful parent-teacher relationship could be very discouraging and stress-provoking for novices. Confronting themselves with this kind of challenge, some novices have already asked their more experienced colleagues for advice:

"After the first few days, I observed that I am failing in trying to communicate well with all the parents. [...] Therefore, I asked for help and my more experienced colleagues taught me some strategies and talked about their own experiences with parents. It also helped that I have other first-year colleagues with the same problem. [...] I admit I am glad that I am not the only one who has this problem, because it would have been harder to keep it to myself." (Participant with 1-year teaching experience)

\section{Discussion and conclusions}

Starting a career in teaching brings about substantial change in one's life, both professionally and personally. In the process of taking control over their teaching, novices pass through several experiences and encounter diverse internal and external factors which shape their understanding of the new 
work context. Clark accurately describes the beginning stages of working in kindergarten as "an emotional roller coaster filled with nerves, exhilaration, and uncertainty" (Clark, 2012, p. 197), as the teacher is now not solely responsible for his/her own learning, but for the children's development and well-being. Moreover, the stressful situations can have a strong impact on the teachers' professional performance, as well as on student outcomes, as highlighted by Arens and Morin (2016).

The experiences reported by kindergarten teachers as challenging, often result in emotional stress or even burnout, leading some of the novices to exiting the profession (Dicke et al., 2015). There is wide agreement that the transition from university to the kindergarten/school setting is often associated with feelings of helplessness or frustration. The demands of a new professional context can often lead to uncertainty and discomfort.

This qualitative study, which includes a total of 16 participants, offers some insights regarding the type of situations novice teachers encounter in their daily practice at kindergarten and the strategies they develop in order to handle them successfully. Our findings indicate that beginning teachers' "challenging moments" descriptions generally emphasize their struggles concerning their own professional development, the school organizational aspects, as well as their relationships with students, colleagues, principals and parents. These results were not surprising since most of the studies that investigate novices' concerns come to the same conclusion (Aarts et al., 2019; Çakmak et al., 2018).

The newly graduates often talk about the support and guidance they received from their more or less experienced colleagues, principals and even former faculty colleagues. In most cases, these people are considered to be the most protective factors in the novices' professional development. On the other hand, our research indicates that the attitude of some of the novices' colleagues and children's parents, as well as their lack of solidarity was perceived by some of the beginning teachers as a constraint on their professional development. Oftentimes, seeking help from another person who may provide another perspective can help greatly in dealing with their own struggles. Thus, it is paramount for principals and more experienced teachers to be aware they play a pivotal role in professional support and 
guidance, as well as in building and maintaining relational trust within the teachers' group so the novice feels he/she is part of a trustworthy community.

The situations reported by beginners were perceived as challenging because they used strategies from their own limited repertoires gained during preservice practicum. Also, some even relied on their intuition to solve problems, which of course can be of value at times, but not always. A mentorship program might prove to be helpful for the novices, as some studies show (Gratch, 1998; Haynes, 2011). In the current study, only some beginners benefited from mentoring program, but even in those cases, the relationship was not very structured and handled very well at all times. Our findings illustrate that six of our teachers sought help when confronted with organizational aspects or managing individual differences among students, but they could not get any support. Unfortunately, in these situations the teacher is left to handle all instructional, organizational and emotional difficulties on his/her own.

Some of the literature on novice teachers focuses on blaming initial teacher education for the problems and struggles newly graduates face in kindergartens and schools. While teacher training can indeed have some deficiencies, it is unrealistic to expect such a short period of time (i.e., 3 years) could adequately equip and prepare the new teacher for all the diverse experiences he/she will encounter in daily practice. Also, theoretical courses and initial practice cannot simulate every single future problematic situation.

Therefore, we believe that criticism in this regard is only partly justified and bigger emphasis should be placed upon a well-designed collaboration process between novice and the educational workplace, with the help of principals. Nevertheless, connection with other novice professionals should be encouraged, as they support each other while gradually developing practices. Designing a high-quality mentorship or collaboration program should be based on studies which investigate novice teachers' voices, their successes, as well as their fears and struggles. All these aspects need to be taken into account in order to provide the novice (mentee) - experienced teacher (mentor) relationship a framework for enhancing meaningful collaboration and support. 
With regards to the limitations of our study, we consider that, although we tried to carry on a thorough research on the novice teachers' struggles, this is a small-scale study mainly based on collecting data from 16 beginning kindergarten teachers through qualitative instruments. Furthermore, the results cannot be transferred to other situations (e.g., higher grades or kindergartens in rural areas), and there is an evident limitation of gender parity, but this situation is a consequence of the fact that there are only a few male educators in the whole country. However, individual experiences and reflections on the most challenging moments newly graduates are confronted with can communicate to us a great deal about the type of situations these professionals encounter on a daily basis and the way they succeed in managing them. Our findings are consistent with those of other studies and nuance them to some extent.

Although there are some limitations of the study, such as the involvement of different ages of novice teachers and a small sample size, these findings contribute to some extent to shaping the future of education. Furthermore, we must be aware of the impact of novices' experiences on their decision to continue or end their teaching journey. Nevertheless, further studies are necessary in order to deepen on what novices, kindergartens and universities can develop and put into practice to foster novices' professional development and well-being.

\section{References}

- Aarts, R., Kools, Q., \& Schildwacht, R. (2019). Providing a good start. Concerns of beginning secondary school teachers and support provided. European Journal of Teacher Education, 1-19.

https://doi.org/10.1080/02619768.2019.1693992

- Alsup, J. (2006). Teacher identity discourses: Negotiating personal and professional spaces. Erlbaum.

- Aoki, N. (2002). Aspects of teacher autonomy: Capacity, freedom and responsibility. In P. Benson \& S. Toogood (Eds.), Learner autonomy 7: Challenges, research and practice (pp. 111-135). Authentik.

- Arens, A. K., \& Morin, A. J. S. (2016). Relations between Teachers' Emotional Exhaustion and Students' Educational Outcomes. Journal of Educational Psychology, 108(6), 800-813. https://doi.org/10.1037/edu0000105

- Beauchamp, C., \& Thomas, L. (2009). Understanding teacher identity: an overview 
of issues in the literature and implications for teacher education. Cambridge Journal of Education, 39(2), 175-189. https://doi.org/10.1080/03057640902902252

- Bernard, H. R., \& Ryan, G. W. (2010). Analyzing qualitative data: Systematic approaches. Sage.

- Billett, S. (2001). Learning through work: Workplace affordances and individual engagement. Journal of Workplace Learning, 13(5), 209-214.

- Blömeke, S., Olsen, R. V., \& Suhl, U. (2016). Relation of student achievement to the quality of their teachers and instructional quality. In T. Nilsen \& J.-E. Gustafsson (Eds.), Teacher quality, instructional quality and student outcomes. IEA Research for Education 2 (pp. 21-50). Springer.

- Britt, P. M. (1997). Perceptions of beginning teachers: Novice teachers reflect upon their beginning experiences [Paper presentation]. Annual Meeting of the Mid-South Educational Research Association, Memphis, TN. https://files.eric.ed.gov/fulltext/ED415218.pdf

- Butt, G., \& Lance, A. (2005). Secondary Teacher Workload and Job Satisfaction. Educational Management Administration \& Leadership, 33(4), 401-422. https://doi.org/10.1177/1741143205056304

- Çakmak, M., Gündüz, M., \& Emstad, A. B. (2018). Challenging moments of novice teachers: survival strategies developed through experiences. Cambridge Journal of Education, 49(2), 147-162. https://doi.org/10.1080/0305764X.2018.1476465

- Clemente, V., Tschimmel, K., \& Marques Vieira, R. (2017). Why a Logbook? A backpack journey as a metaphor for product design education. The Design Journal, 20(1), S1530-S1542. https://doi.org/10.1080/14606925.2017.1352677

- Corcoran, E. (1981). Transition Shock. The Beginning Teacher's Paradox. Journal of Teacher Education, 32(3), 19-23. https://doi.org/10.1177/002248718103200304

- Darling-Hammond, L. (2000). Teacher quality and student achievement: A review of state policy evidence. Education Policy Analysis Archives, 8(1), 1-44. https://doi.org/10.14507/epaa.v8n1.2000

- Darling-Hammond, L. (2014). Strengthening clinical preparation: The holy grail of teacher education. Peabody Journal of Education, 89(4), 547-561. https://doi.org/10.1080/0161956X.2014.939009

- Darling-Hammond, L., \& Sykes, G. (2003). Wanted: A national manpower policy for education. Education Commission of the States.

- Davis, E. A., Petish, D., \& Smithey, J. (2006). Challenges new science teachers face. Review of Educational Research, 76(4), 607-651. https://doi.org/10.3102/00346543076004607

- Denscombe, M. (2010). The good research guide for small-scale social research projects (4th ed.). Open University Press.

- Dicke, T., Parker, P. D., Holzberger, D., Kunina-Habenicht, O., Kunter, M., \& Leutner, D. (2015). Beginning Teachers' Efficacy and Emotional Exhaustion: 
Latent Changes, Reciprocity, and the Influence of Professional Knowledge. Contemporary Educational Psychology, 41, 62-72.

https://doi.org/10.1016/j.cedpsych.2014.11.003

- Goe, L. (2007). The link between teacher quality and student outcomes: A research synthesis. National Comprehensive Center for Teacher Quality.

- Gordon, S. P., \& Maxey, S. (2000). How to Help Beginner Teachers Succeed. Association for Supervision and Curriculum Development.

- Gratch, A. (1998). Beginning teacher and mentor relationships. Journal of Teacher Education, 49(3), 220-227.

- Haynes, L. (2011). Novice teachers' perceptions of their mentoring experiences. ProQuest Dissertations \& Theses (PQDT).

- Hanushek, E. A., Kain, J. F., O'Brien, D. M., \& Rivkin, S. G. (2005). The Marketfor Teacher Quality. National Bureau for Economic Research.

- Hattie, J. A. (2009). Visible learning: A synthesis of 800+ meta-analyses on achievement. Routledge.

- Huang, J., Lock, K. Y. N., \& Teng, F. (2019). Autonomy in English Language Teaching: A Case Study of Novice Secondary School Teachers in Hong Kong. Chinese Journal of Applied Linguistics, 42(1), 3-20.

https://dx.doi.org/10.1515/cjal-2019-0001

- Kelchtermans, G., \& Ballet. K. (2002). The Micropolitics of Teacher Induction. A Narrative-Biographical Study on Teacher Socialisation. Teaching and Teacher Education, 18(1), 105-120.

- Kim, K., \& Roth, G. (2011). Novice teachers and their acquisition of work-related information. Current Issues in Education, 14(1), 1-28.

- Kuckartz, U., \& Rädiker, S. (2019). Analyzing Focus Group Data. In U. Kuckartz \& S. Rädiker, Analyzing Qualitative Data with MAXQDA (pp. 201-217). Springer International Publishing.

- Kunter, M., Klusmann, U., Baumert, J., Richter, D., Voss, T., \& Hachfeld, A. (2013). Professional competence of teachers: Effects on instructional quality and student development. Journal of Educational Psychology, 105(3), 805820. https://dx.doi.org/10.1037/a0032583

- Liu, X. S., \& Meyer, J. P. (2005). Teachers' perceptions of their jobs: A multilevel analysis of the teacher follow-up survey for 1994-95. Teachers College Record, 107(5), 985-1003. https://doi.org/10.1111/j.1467-9620.2005.00501.x

- Marshall, C., \& Rossman, G. B. (2011). Designing qualitative research. Sage Publications.

- McCann, T. M., \& Johannessen, L. R. (2004). Why Do New Teachers Cry?. The Clearing House: A Journal of Educational Strategies, Issues and Ideas, 77(4), 138-145. https://doi.org/10.3200/TCHS.77.4.138-145

- McCann, T. M., Johannessen, L. R., Ricca, B. P. (2005). Supporting Beginning English Teachers: Research and Implications for Teacher Induction. National 
Council of Teachers of English.

- Naylor, C, \& White, M. (2010). The Worklife of BC Teachers in 2009. BC Teachers' Federation.

http://bctf.ca/uploadedFiles/Public/Issues/WorklifeWorkload/2009/FullReport.pdf

- Nieme, H. (2002). Active learning — a cultural change needed in teacher education and schools. Teaching and Teacher Education, 18(7), 763-780.

- OECD. (2005). Teachers Matter: Attracting, Developing, and Retaining Effective Teachers. OECD Publishing.

- OECD. (2019). Providing Quality Early Childhood Education and Care: Results from the Starting Strong Survey 2018. TALIS, OECD Publishing.

- Olsen, B. (2010). Teaching for success: Developing your teacher identity in today's classroom. Paradigm.

- Patton, M. Q. (2002). Qualitative research and evaluation methods. Sage Publications.

- Rivkin, S. G., Hanushek, E. A., \& Kain, J. F. (2005). Teachers, schools, and academic achievement. Econometrica, 73(2), 417-458. https://doi.org/10.1111/j.1468-0262.2005.00584.x

- Romano, M. E. (2005). Preservice teachers' reflections on observed "bumpy moments" in teaching: Implications for teacher education. The Teacher Educator, 40(4), 257-277. https://doi.org/10.1080/08878730509555365

- Salvo, J. C., Kibble, L., Furay, M. A., \& Sierra, E. A. (2005). Surviving Day One ... and Beyond. Supporting New Educators, 62(8), 24-28.

- Scheerens, J. (2016). Educational effectiveness and ineffectiveness. A Critical Review of the Knowledge Base. Springer Science+Business Media Dordrecht.

- Smith, K., \& Sela, O. (2005). Action Research as a bridge between pre-service teacher education and in-service professional development. The European Journal of Teacher Education, 28(3), 293-311.

https://doi.org/10.1080/02619760500269418

- Sözen, P. H. (2018). Challenges of Novice Teachers. International E-Journal of Advances in Education, 4(12), 278 - 282. https://doi.org/10.18768/ijaedu.478254

- Strauss, A., \& Corbin, J. M. (1990). Basics of qualitative research: Grounded theory procedures and techniques. Sage Publications.

- Teddlie, C., \& Yu, F. (2007). Mixed Methods Sampling: ATypology with Examples. Journal of Mixed Methods Research, 1(1), 77-100. https://doi.org/10.1177/2345678906292430

- Tye, B. B., \& O'Brien, L. (2002). Why are experienced teachers leaving the profession? Phi Delta Kappan, 84(1), 24-32. http://dx.doi.org/10.1177/003172170208400108

- Veenman, S. (1984). Perceived Problems of Beginning Teachers. Review of Educational Research, 54(2), 143-178. 
http://dx.doi.org/10.3102/00346543054002143

- Wiswall, M. (2013). The dynamics of teacher quality. Journal of Public Economics, 100, 61-78. https://doi.org/10.1016/j.jpubeco.2013.01.006

The online version of this article can be found at: http://revped.ise.ro/category/2020-en/

\section{$(C C)$ EY-NC-BA}

This work is licensed under the Creative Commons Attribution-NonCommercial-ShareAlike 4.0 International License.

To view a copy of this license, visit http://creativecommons.org/licenses/by- $n c-s a / 4.0 /$ or send a letter to Creative Commons, PO Box 1866, Mountain View, CA 94042, USA.
Versiunea online a acestui articol poate fi găsită la: http://revped.ise.ro/category/2020-ro/

\section{(c) DY-NC-BA}

Această lucrare este licen iată sub Creative Commons Attribution-NonCommercial-ShareAlike 4.0 International License.

Pentru a vedea o copie a acestei licen $e$, vizita $i$ http://creativecommons.org/licenses/by-nc-sa/4.0/ sau trimite i o scrisoare către Creative Commons, PO Box 1866, Mountain View, CA 94042, SUA. 


\title{
COMPETEN ELE DE CETĂ ENIE DIGITALĂ ALE VIITORILOR PROFESIONIŞTI ÎN EDUCA IE. ABORDĂRI ÎN CONTEXTUL MĂSURILOR DE DISTAN ARE SOCIALĂ GENERATE DE RĂSPÂNDIREA COVID-19
}

\author{
Mirela Alexandru* \\ Iulia Niya Cui, Carmen Dobri, Cristian-Vasile Ghi ă, \\ Mihaela-Elena Ionică, Alina Andreea Muşescu, \\ Veronica Lulu Viorica Serea** \\ Universitatea din Bucureşti, \\ Facultatea de Psihologie şi Ştiin ele Educa iei, \\ Bucureşti, România \\ alexandru.mirela.elena@gmail.com
}

Leyla Safta-Zecheria***

Universitatea de Vest din Timişoara, Facultatea de Sociologie şi Psihologie,

Timişoara, România

\section{Rezumat}

Măsurile de distan are socială impuse de pandemia COVID-19 au condus aproape peste noapte la digitalizarea activită ilor educa ionale din România şi din lume, iar această transformare a făcut mult mai vizibilă nevoia de dezvoltare a unor comportamente responsabile şi adecvate în mediul online şi ne-a făcut să ne punem întrebarea: „Ce competen e de cetă enie digitală au viitorii profesionişti în educa ie?”.

\footnotetext{
* Drd., Facultatea de Psihologie şi Ştiin ele Educa iei, Departamentul Ştiin ele Educa iei, Universitatea din Bucureşti, Bucureşti, România.

** Studen i Licen ă, Facultatea de Psihologie şi Ştiin ele Educa iei, Departamentul Ştiin ele Educa iei, Universitatea din Bucureşti, Bucureşti, România.

***Dr., Facultatea de Sociologie şi Psihologie, Departamentul Ştiin ele Educa iei,

Universitatea de Vest din Timişoara, Timişoara, România.
} 
Pentru a răspunde la această întrebare am administrat un chestionar online structurat, cu răspunsuri închise, care a vizat identificarea competen elor de cetă enie digitală distribuite pe trei dimensiuni (respect, educa ie şi protec ie), ale studen ilor din programele de licen ă în ştiin ele educa iei din România. Studiul a arătat că responden ii au competen e (în termen de cunoştin e şi atitudini) de cetă enie digitală bine dezvoltate, dar că este nevoie de un accent mai pronun at pe dezvoltarea abilită ilor de a ac iona pentru a transforma aceste cunoştin e şi atitudini în practică. De asemenea, măsurile de distan are socială şi digitalizarea, asociate procesului educa ional, apar atât ca factori de stres, cât şi ca o oportunitate de dezvoltare a competen elor de cetă enie digitală prin învă are experien ială.

Cuvinte-cheie: cetă enie digitală, educa ie în perioada pandemiei COVID-19, formare ini ială a profesorilor.

\section{Abstract}

Social distancing measures imposed by the COVID-19 pandemic have led almost overnight to the digitalization of educational activities in Romania and elsewhere. This transformation has rendered visible the need to develop adequate and responsible online behavior to an unprecedented extent and has led us to ask: "Which are the digital citizenship competencies of the future professionals in the field of education?". To answer this question, we administered an online questionnaire focusing on identifying digital citizenship competences of undergraduate students in educational sciences in Romania. Digital citizenship competences were structured along three dimensions: respect, education and protection. Our study has shown that respondents had well developed digital citizenship competences in terms of knowledge and attitudes and that there is a need to insist more on skills that translate attitudes and knowledge into action. Moreover, the study has shown that social distancing measures and the associated rapid digitalization of educational activities can be interpreted both as stress factors, as well as an opportunity to develop digital citizenship competences through experiential learning.

Keywords: digital citizenship, education during COVID-19 pandemic, pre-service teacher training. 


\section{Introducere}

Lumea este într-o continuă schimbare din perspectiva factorilor sociali şi economici, aceştia lăsându-şi amprenta asupra impactului pe care îl are tehnologia, în spe ă noile tehnologii ale informa iei şi comunicării. Cantitatea de informa ie se dublează la fiecare doi ani (Farmer, 2011), iar oamenii au nevoie să evalueze resursele cu mai mare aten ie şi să afle cum să folosească informa iile într-o manieră relevantă pentru rezolvarea problemelor şi luarea deciziilor. Mai mult ca oricând ac iunile petrecute în online au un impact clar asupra vie ii în offline, de aceea se pune problema comportamentului nostru social în mediul digital, respectiv cum ac ionăm adecvat şi responsabil în online. Pentru sistemul educa ional acest aspect reprezintă o nouă provocare, atât în privin a formării de competen e pentru a ac iona responsabil în mediul online, în rândul specialiştilor în educa ie, cât şi în privin a dezvoltării de politici şi practici educa ionale, care să sus ină la nivel macro şi micro dezvoltarea de competen e necesare unui comportament adecvat în mediul digital în rândul beneficiarilor sistemului educa ional. Sistemul educa ional are o mare răspundere deoarece este sistemul social care facilitează transferul de norme sociale către noua genera ie, o genera ie expusă încă de timpuriu la oportunită ile şi provocările utilizării tehnologiei digitale în compara ie cu genera iile anterioare.

Recenta criză provocată de răspândirea COVID-19 a dus la suspendarea activită ilor educa ionale fa ă în fa ă atât în sistemul preuniversitar cât şi în cel universitar în România, dar şi în multe alte ări. Pentru prima dată în istorie, utilizarea tehnologiei digitale a devenit indispensabilă pentru continuarea activită ilor educa ionale. Această criză a scos la iveală mult mai repede decât ne-am fi aşteptat oportunită ile educa ionale oferite de mediul digital, dar şi lipsa de pregătire în acest domeniu. Alfabetizarea digitală a fost în România un element de interes în ultimii ani, aceasta fiind abordată în 2015 prin Strategia Na ională privind Agenda Digitală pentru România 2020, în care s-a pus accent pe dezvoltarea competen elor TIC (MCSI, 2015). Din păcate, conform studiilor recente, alfabetizarea digitală încă se află la început de drum, România fiind printre ările din Uniunea Europeană cu cele mai slabe competen e digitale şi cu o discrepan ă semnificativă între urban şi rural (Eurostat, 2019). Acest lucru este îngrijorător în rela ie cu elementele centrale ale studiului, respectiv competen ele de cetă enie digitală, deoarece acestea sunt puternic influen ate de alfabetizarea digitală. 
Situa ia slabelor competen e digitale, pe care o considerăm un aspect problematic în contextul actual, a motivat şi fundamentat acest studiu, generând întrebări legate de competen ele de cetă enie digitală ale viitorilor profesionişti în educa ie din România. Cât de bine ştiu studen ii de la programele de licen ă din domeniul ştiin elor educa iei din România să se raporteze la mediul digital? Care sunt atitudinile, cunoştin ele şi abilită ile practice care marchează felul în care ei interac ionează în mediul digital? Câte din aceste competen e au fost dobândite în decursul programului de studiu? Şi cât de pregăti i se simt viitorii profesionişti în educa ie să transfere aceste competen e către mediul şcolar şi alte medii educa ionale în viitor?

Considerăm că rezultatele cercetării vor fi relevante dincolo de prezenta criză provocată de răspândirea COVID-19, deoarece procesul de digitalizare a educa iei şi de întrepătrundere între via ă şi educa ia online şi cea offline sunt în plină desfăşurare. Mai mult decât atât, investigând competen ele de cetă enie digitală contribuim nu numai la discu ii despre abilită i de utilizare a tehnologiei, ci şi la cele despre normativitatea utilizării tehnologiei, vizând comportamentele responsabile ale viitorilor profesionişti în educa ie în utilizarea tehnologiei, dar şi capacitatea acestora de a sus ine transferul acestor competen e în contexte educa ionale către ceilal i.

\section{Cetă enia digitală - valen e şi dimensiuni}

Istoric, cetă enia a fost asociată cu dreptatea şi responsabilitatea de a trăi în comunitate. Într-o epocă digitală, cetă enia străbate atât lumea offline, cât şi online, acestea fiind reprezentate de via a reală, respectiv de via a virtuală. Cetă enia digitală merge dincolo de cetă enia na ională sau regională, oameni de pretutindeni intră în contact în mediul digital, de aceea avem nevoie de norme şi comportamente responsabile, care să ne faciliteze utilizarea acestui spa iu digital împărtăşit.

Conceptual, cetă enia digitală a apărut încă din anii 1980, odată cu apari ia calculatoarelor proprii, când tehnologia a început să se dezvolte, acestea reuşind să capete un rol important în vie ile oamenilor (Hamutoğlu \& Ünal, 2015). 
În rândul profesioniştilor din educa ie, cetă enia digitală a câştigat popularitate odată cu creşterea numărului de instrumente pedagogice bazate pe tehnologie. Recent, această popularitate a atins o nouă dimensiune prin digitalizarea unei bune păr i din activită ile educa ionale în timpul crizei cauzate de răspândirea COVID-19.

Doi teoreticieni centrali ai cetă eniei digitale au definit acest concept ca fiind ,ansamblul de norme care guvernează utilizarea adecvată şi responsabilă a tehnologiei" (Ribble \& Bailey, 2007, p. 10). Prin urmare, din punctul de vedere al proceselor de învă are, cetă enia digitală se situează în primul rând în sfera atitudinală. $\mathrm{Cu}$ toate acestea, având în vedere că utilizarea responsabilă a tehnologiei presupune atât abilită i, cât şi cunoştin e, putem vorbi de mai multe tipuri de competen e din sfera cetă eniei digitale, care pot fi dezvoltate prin învă are în mediul şcolar şi nu numai.

În egală măsură, după cum observă şi Ribble şi Bailey (2007), în general arhitec ii şi actorii procesului educa ional şcolar consideră că elevii vor şti de la sine cum arată un comportament adecvat şi responsabil în mediul digital. De multe ori elevii observă adul ii folosind tehnologia în moduri nepotrivite şi trag concluzia că aceasta este norma pe care trebuie să o urmeze şi ei (Ribble et al., 2004).

De-a lungul timpului, cetă enia digitală a fost abordată de numeroşi autori şi definită în repere de politici publice şi de practici prin diferite dimensiuni. Conform lui Curran şi Ribble (2017), cetă enia digitală se identifică prin nouă elemente: (1) acces, (2) comer, (3) comunicare, (4) litera ie, (5) (n-)etichetă, (6) legisla ie digitală, (7) drepturi si responsabilită i, (8) sănătate şi bunăstare, precum şi (9) siguran ă digitală, aceste elemente fiind organizate în trei mari dimensiuni şi anume: respect, educa ie şi protec ie - REP. Spa iul acestei lucrări nu ne permite o detaliere corespunzătoare a acestui cadru de analiză, dar men ionăm că el a făcut obiectul unei analize detaliate recente în limba română (Mali a \& Grossek, 2019).

Comisia Europeană, prin instrumentul DigiComp 2.0 „Competen a digitală. Cadru pentru cetă eni”, defineş̧te cetă enia digitală ca fiind formată din dimensiunile: informa ii şi alfabetizarea în prelucrarea datelor, comunicare şi colaborare, realizarea de con inut digital, siguran ă şi rezolvarea de probleme 
(Vuorikari et al., 2016). Tot din sfera demersurilor de conceptualizare pentru îmbunătă irea practicilor şi politicilor publice, Consiliul Europei structurează conceptul de cetă enie digitală, prin intermediul Proiectului ,Digital Citizenship Education", în 10 dimensiuni, respectiv: conştientizarea consumatorilor, confiden ialitate şi securitate, drepturi şi responsabilită i, participare activă, prezen ă online şi comunicare, sănătate şi stare de bine, etică şi empatie, acces şi incluziune, media şi alfabetizare în gestionarea informa iilor, învă are şi creativitate (Consiliul Europei, 2019).

Măsurile de distan are socială impuse de guverne peste tot în lume, pentru a încetini răspândirea COVID-19, au avut un impact sim itor asupra organizării proceselor educa ionale, atât în învă ământul obligatoriu, cât şi în ciclurile superioare de învă ământ. Putem remarca o accelerare a procesului de digitalizare a educa iei prin cursuri universitare şi şcolare transferate în online. Putem vorbi despre o digitalizare alertă, în regim de criză, care presupune prezen a competen elor necesare navigării cu succes a spa iului digital la to i profesioniştii din educa ie, fără a construi aceste măsuri pe o pregătire prealabilă. Această stare de fapt ne-a determinat să concepem următorul parcurs de cercetare consolidat de abordările teoretice, prezentate anterior, cu scopul de a afla care sunt competen ele de cetă enie digitală ale viitorilor profesionişti în educa ie (studen i ai diferitelor specializări în ştiin ele educa iei ale mai multor universită i din România).

Demersul nostru de cunoaştere este fundamentat pe presupozi ia că prezen a acestor competen e în rândul acestei genera ii de studen i, majoritar din genera ii de nativi digitali (Prensky, 2001), poate avea un efect multiplicator atât prin digitalizarea demersurilor de practică pedagogică şi implicit prin transferul accelerat către practicieni în şcoli, cât şi pe termen lung prin activitatea profesională în domeniul educa iei a acestei genera ii de studen i.

\section{Metodologia cercetării}

Cercetarea curentă se bazează pe un chestionar cu răspunsuri închise, care a fost administrat online studen ilor din programele de studiu de la nivelul de licen ă din domeniul ştiin elor educa iei din România. Chestionarul a fost trimis utilizând instrumente digitale. A rezultat un eşantion de convenien ă de 
438 de responden i de la 12 universită i din ară, acoperind toate cele trei specializări (pedagogia învă ământului primar şi preşcolar, pedagogie şi psihopedagogie specială). Eşantionul de convenien ă prezentat aici este cel mai probabil distorsionat în direc ia prezentării unui tablou mai favorabil competen elor de cetă enie digitală ale viitorilor profesionişti în educa ie, deoarece este posibil ca studen ii care au răspuns voluntar la rugămintea de a completa un chestionar aflat în mediul digital şi care face referire în mod explicit la această temă, să fie mai conştien i şi dornici să-şi dezvolte propriile competen e de cetă enie digitală comparativ cu studen ii din aceeaşi popula ie care nu au avut acces sau nu au dorit să răspundă la chestionar. Mai mult decât atât, în mod evident responden ii sunt cel mai probabil persoane cu acces relativ constant la mediul digital, lucru care este posibil să nu fie valabil pentru to i membrii popula iei pe care o studiem.

Chestionarul administrat a fost construit cu obiectivul de a identifica prezen a competen elor de cetă enie digitală ale studen ilor de la diferitele specializări din domeniul ştiin elor educa iei, precum şi disponibilitatea şi implicarea lor în transferul acestor competen e către spa iul educa ional în scopul contribuirii la calitatea procesului de digitalizare a educa iei în timpul crizei provocate de răspândirea COVID-19, precum şi dincolo de ea. Investigarea acestor domenii se va face vizând orizontul de timp, atât în rela ie cu prezenta situa ie a digitalizării accelerate în educa ie, provocată de distan area socială, cât şi în rela ie cu un orizont de timp mediu spre lung, care are în vedere transferul acestor competen e către sistemul educa ional, prin intermediul activită ii profesionale educa ionale a viitorilor absolven i ai diferitelor specializări din domeniul ştiin elor educa iei.

Conform celor care au propus acest concept (Ribble \& Bailey, 2007), cetă enia digitală se compune din nouă elemente, pe care chestionarul prezent le opera ionalizează, în rela ie, pe de-o parte, cu mediul universitar, ca un poten ial spa iu al dobândirii acestor competen e, şi cu mediul preuniversitar, ca un poten ial spa iu de implicare, în scopul transferului acestor competen e, pe de altă parte.

Cele nouă elemente, care au fost abordate anterior în partea de fundamentare teoretică, au fost adaptate contextului educa ional studiat, însă nu toate dimensiunile abordate în literatură au fost incluse în studiu, de exemplu: 
comer ul digital, deşi este un element definitoriu al cadrului de analiză al cetă eniei digitale, nu se regăseşte în chestionar, deoarece am considerat că nu este un element cheie pentru analiza pe care dorim să o propunem. Eticheta socială digitală (neticheta) a fost opera ionalizată pornind atât de la întrebările orientative propuse de Ribble şi Bailey (2007), cât şi pornind de la lucrarea de referin ă a lui John Suler (2004), ,Efectul de dezinhibi ie online”, lucrare care a fundamentat atât studiul, cât şi combaterea fenomenului de cyberbullying. Cum no iunea şi combaterea cyber-bullyingului sunt aspecte centrale pentru domeniul educa ional, dimensiunea de netichetă a fost redefinită pentru a include şi fenomenul de cyber-bullying. Foarte recent fenomenul de zoombombing şi-a făcut locul în vocabularul de specialitate, cu referire la comportamentul perturbator şi/sau anonim din timpul cursurilor online. Am inclus un set de întrebări specifice, care să facă referire şi la acest fenomen. De asemenea, am adăugat la elementele care compun no iunea de cetă enie digitală şi no iunea de sănătate şi stare de bine digitală ca un element de sine stătător. Această extindere a conceptului se bazează pe abordarea promovată de Consiliul Europei (Frau-Meigs et al., 2017), dar şi prin dezvoltarea ulterioară a cadrului propus de Ribble (Curran \& Ribble, 2017). Pentru a opera ionaliza această dimensiune am interpretat elemente relevante din scala psihometrică de evaluare a cetă eniei digitale propuse de Nordin et al. (2016). Elementele legate de legisla ia digitală, de drepturile şi responsabilită ile din mediul digital au fost opera ionalizate ca parte a unei singure sec iuni. Mai mult decât atât, am inclus la finalul chestionarului o meta-dimensiune autoreflexivă a cetă eniei digitale, care să ne permită să identificăm raportarea individuală a responden ilor la calitatea de cetă ean digital.

Pentru a facilita analiza datelor într-un mod uşor de urmărit, am folosit cele trei dimensiuni propuse de Curran şi Ribble (2017), care încorporează elementele cetă eniei digitale într-un cadru coerent, anume: I. Respect (încorporează dimensiunea accesului digital şi pe cea a netichetei), II. Educa ie (include elementele legate de comunicare şi de alfabetizare digitală) şi în final III. Protec ie (încorporează sănătatea şi starea de bine digitală, precum şi drepturile şi obliga iile legale în mediul digital). Considerăm că sec iunea din chestionar referitoare la meta-competen e de cetă enie digitală se află la intersec ia celor trei dimensiuni şi include aspecte relevante pentru toate cele trei dimensiuni. 


\section{Analiza şi interpretarea datelor}

Cum am men ionat mai sus, interpretarea rezultatelor s-a făcut pornind de la cele trei dimensiuni sumative ale cetă eniei digitale: respect, educa ie şi protec ie prin analiza statisticilor descriptive, care au rezultat în urma agregării răspunsurilor tuturor responden ilor la întrebările închise din chestionar.

Elementele care constituie cele trei dimensiuni au fost opera ionalizate în chestionar pornind de la contextul actual marcat de transferul activită ilor educa ionale universitare în mediul online, precum şi din punctul de vedere al poten ialului unui transfer de competen e către mediul educa ional pe termen mediu şi lung. Vom aborda rezultatele cercetării cu privire la aceste dimensiuni în cele ce urmează.

\subsection{Descrierea eşantionului}

Eşantionul pentru acest studiu a fost unul de convenien ă, format din 438 de studen i de la ciclul de licen ă din domeniul ştiin elor educa iei, distribu ia pe specializări fiind următoarea: $67,7 \%$ - pedagogia învă ământului primar şi preşcolar, 27,7\% - pedagogie şi 4,6\% - psihopedagogie specială. Responden ii frecventează cursurile la zi $(84,5 \%)$ şi la distan ă $(15,3 \%)$ din 12 universită i din România (Universitatea din Bucureşti - 25,1\%; Universitatea „Lucian Blaga" din Sibiu - 23,1\%; Universitatea de Vest din Timişoara - 19,9\%; Universitatea „Valahia” din Târgovişte - 17,1\%; Universitatea „Eftimie Murgu” din Reşi a - 7,1\%; Universitatea „Aurel Vlaicu” din Arad - 2,5\%; Universitatea „Babeş-Bolyai” din Cluj - 1,5\%; Universitatea Transilvania din Braşov - 1\%; Universitatea „Ştefan cel Mare” din Suceava - 1\%; Universitatea din Piteşti - 1\%; Universitatea „Ovidius” din Constan a - 1\%; Universitatea „Dunărea de Jos” din Gala i-0,5\%). Distribu ia pe gen a acestora este $96,8 \%$ gen feminin, $1,6 \%$ masculin şi $1,6 \%$ care preferă să nu răspundă. Vârstele studen ilor participan i la studiu sunt distribuite astfel: 18 - 25 ani $(65,1 \%)$, 26 - 30 ani (6,4\%), 31 - 40 ani (16,4\%), peste 40 de ani $(11,2 \%)$, iar un procent de $0,7 \%$ preferă să nu răspundă. 


\subsection{Respectul în mediul digital}

Cum am men ionat şi mai sus, dimensiunea respectului digital se compune, în cazul cercetării noastre, din elementele de acces la mediul digital şi acelea de netichetă (de etichetă socială în mediul digital). Pe scurt, din punctul de vedere al accesului, responden ii par o categorie privilegiată, reuşind să continue cu succes studiile în online. Totuşi, este de remarcat că un număr semnificativ de studen i participă folosind mijloace mai pu in adecvate (de tipul telefonului smart) sau împart utilizarea dispozitivului cu alte persoane. Din punctul de vedere al netichetei, responden ii au înfă işat un tablou interesant: deşi mul i sunt de părere că pot recunoaşte comportamente inadecvate în online (cyberbullying, hatespeech, flaming şi zoom-bombing), un număr semnificativ mai mic este şi capabil să ac ioneze pentru a limita astfel de comportamente. Această tendin ă riscă să se perpetueze în mod negativ în mediul şcolar, deoarece viitorii profesionişti în educa ie vor putea într-o mai mică măsură să explice altora cum să ac ioneze pentru a opri aceste comportamente.

Pe larg, majoritatea covârşitoare a responden ilor a putut participa la activită i online în timpul pandemiei $(80,6 \%)$ şi numai o mică parte (19 responden i) nu au putut participa deoarece nu au avut acces la un mijloc tehnologic adecvat. Din punctul de vedere al accesului, este de remarcat că un număr deloc neglijabil de studen i participă la cursuri folosind telefonul smart (mai mult de 30\%) şi că există studen i (în jur de 4\%), care au răspuns la chestionar şi nu pot participa la cursuri online în mod regulat, din lipsa mijloacelor tehnologice. Luând în considerare lipsa de reprezentativitate a eşantionului, discutată la sec iunea metodologică, numărul real de studen i afla i în această situa ie este cel mai probabil semnificativ mai mare. De asemenea, $8,4 \%$ nu au putut participa la cursuri online din cauza prezen ei altor responsabilită i.

Dacă ne uităm cu aten ie la modalitatea de participare, doar pu in peste $60 \%$ folosesc laptopul pentru a participa la cursuri, iar mai mult de 30\% folosesc telefonul smart, fapt care ne face să deducem că, pe termen lung, o participare la cursuri prin intermediul telefonului smart poate duce la o scădere a calită ii învă ării, precum şi la o stare de bine diminuată, cauzată de utilizarea improprie şi îndelungată a unui instrument care nu a fost destinat participării frecvente la întâlniri virtuale. 
Procent din activitățile universitare de învăţare care se petreceau online înainte de criza provocată de răspândirea COVID-19 (prin intermediul platformelor educaționale google classroom, Kahoot, mentimeter etc.) conform studenților.

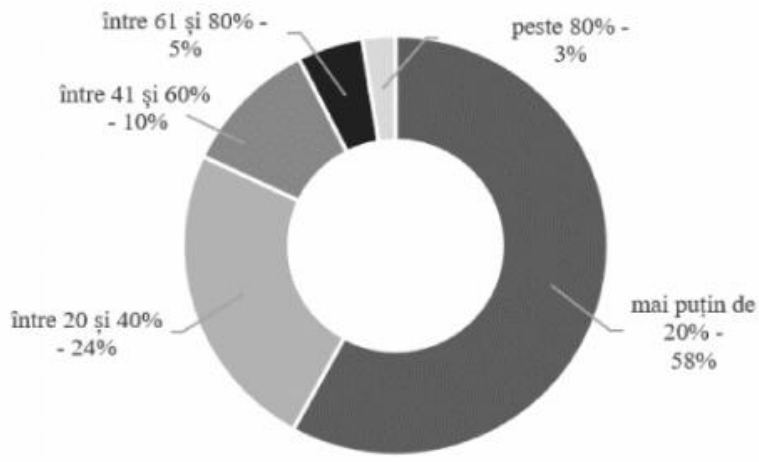

Figura nr. 1. Activită ile de învă are în online înainte de criza COVID-19

Întreba i despre entitatea care ar trebui să asigure instrumentele necesare participării la activită ile universitare online a studen ilor care nu de in aceste mijloace, numai 50,9\% sunt cu totul de acord că universitatea ar avea această răspundere. Când vine vorba despre mediul preuniversitar, tabloul se schimbă, întrucâtva coerent cu diferen a între învă ământul obligatoriu şi învă ământul facultativ. Mai mult de 66,2\% sunt complet de acord că Ministerul Educa iei şi Cercetării sau şcoala ar trebui să asigure instrumentele necesare, în aşa fel încât elevii să poată participa la şcoala online, iar 47,4\% sunt complet de acord că şi autorită ile locale ar trebui să aibă aceeaşi responsabilitate.

Este, de asemenea, important să remarcăm că măsurile de distan are socială, impuse pentru diminuarea răspândirii COVID-19, au avut un impact sim itor asupra digitalizării educa iei universitare, dacă $58 \%$ dintre responden i apreciază că, înainte de criza COVID-19, mai pu in de $20 \%$ din activită ile de învă are academică se petreceau online, iar după măsurile de distan are socială, $62,6 \%$ dintre responden i sunt de părere că este vorba de mai mult de $80 \%$ din activită i. 
Procent din activitățile universitare de învàțare care se petrec online dupã criza provocată de răspândirea COVID-19 (prin intermediul platformelor zoom, google meet, dar și google classroom, spre deosebire de activități coordonate telefonic, reprogramate, etc) conform studenților.

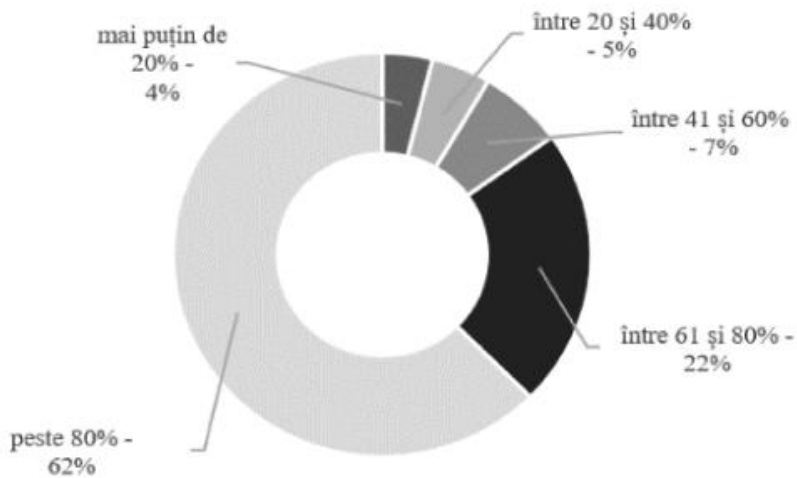

Figura nr. 2. Activită ile de învă are în online după criza COVID-19

Din toate elementele constitutive ale cetă eniei digitale, neticheta este poate cea mai importantă, deoarece explorează dintr-o perspectivă normativă comportamentul online în rela ie cu cel offline. Studen ii responden i demonstrează un grad înalt de reflexivitate în rela ie cu propriul comportament online (majoritatea covârşitoare este relativ sau complet conştientă de faptul că oamenii pot ac iona mai pu in cumpătat online şi se gândesc relativ mult sau chiar foarte mult la consecin ele ac iunilor lor online pentru alte persoane şi mai ales pentru viitorul propriu). De asemenea, majoritatea covârşitoare a responden ilor ştie să recunoască o situa ie de cyber-bullying sau o situa ie de zoom-bombing (comportamente anonime şi/sau răuvoitoare afişate în timpul unor cursuri online), o majoritate relativă ştie să recunoască o situa ie de propagare de ură în mediul digital. Totuşi, întreba i dacă ar şti să ac ioneze pentru a opri aceste comportamente, un număr mult mai mic de responden i a fost de acord că ar şti cum să ac ioneze, iar un număr similar de responden i s-ar sim i capabili să explice altcuiva cum ar trebui să ac ioneze. Din aceste date putem concluziona că, deşi viitorii profesionişti în educa ie de in elemente extinse de cetă enie digitală la nivel de cunoştin e, ei nu de in în aceeaşi măsură abilită i în acest sens. De aceea, ar fi important ca abilită ile de a ac iona în mediul online în solidaritate cu persoane sau grupuri vulnerabile 


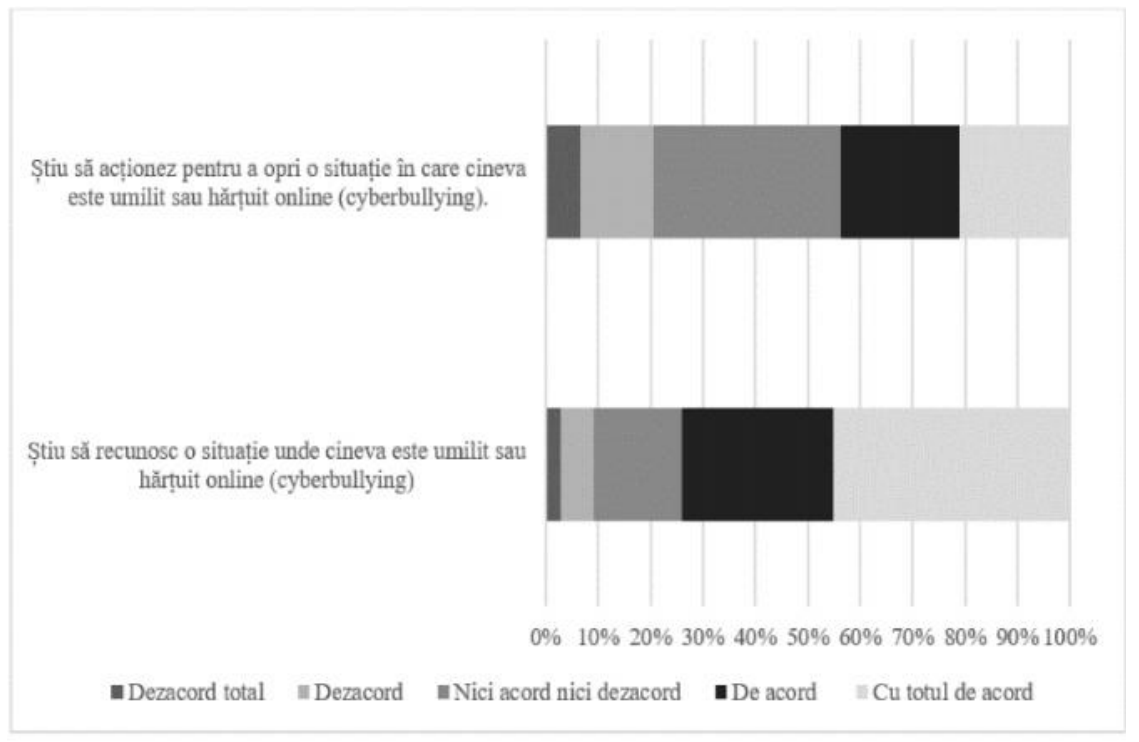

Figura nr. 3. Cyberbullying

sau pentru a păstra un climat favorabil de studiu, să fie dezvoltate în cadrul programelor de ştiin ele educa iei.

\section{3. $\quad$ Educa ie digitală}

În ultimele luni, lumea a cunoscut o creştere a utilizării tehnologiei în scopuri educa ionale şi personale, această pandemie făcând ca tehnologia să devină o parte vitală a modului în care noi interac ionăm unii cu al ii, dar şi cum ne educăm, afectând multe aspecte ale vie ii cotidiene. Tinerii din ziua de azi (nativi digitali) şi nu numai sunt obişnui i să acceseze sursele media oriunde şi oricând, dar fără alfabetizare digitală, ei rămânând simpli utilizatori amatori de tehnologie.

În ceea ce priveşte dimensiunea educa iei pentru cetă enia digitală, comunicarea în mediul online se bucură de aten ia responden ilor. De exemplu, $56,2 \%$ se gândesc bine înainte să formuleze un mesaj scris către colegi sau cadrele didactice, deoarece ştiu că mesajele rămân salvate. Doar 1,4\% nu acordă niciodată aten ie acestui aspect. 


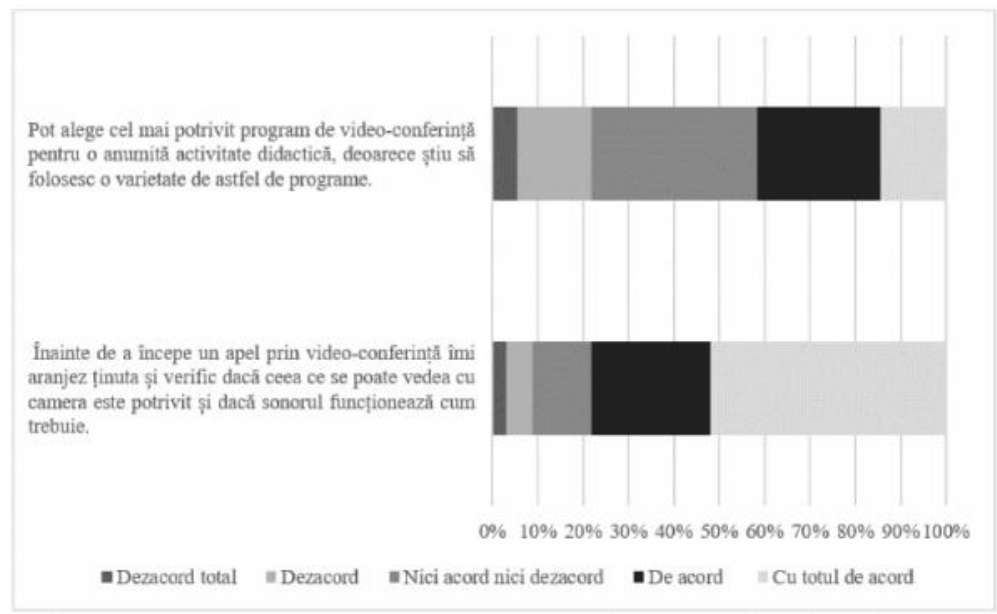

Figura nr. 4. Video-conferin e

Pregătirea pentru sus inerea unui curs în mediul online nu primeşte o aten ie la fel de mare ca pregătirea unei întâlniri fa ă în fa ă, în mediul universitar. Mai mult de jumătate dintre responden i sus in că sunt aten i întotdeauna la inuta pe care o au într-un apel prin video-conferin ă. 114 (26\%) sus in că uneori sunt aten i la inuta pe care o au şi la ce se poate vedea în jurul lor în timpul unui apel prin video-conferin ă. Comunicarea online se poate realiza şi fără a fi camera pornită, acesta putând fi un motiv care îi face pe studen i să nu acorde aten ie mereu inutei pe care o au în timpul unui curs prin video-conferin ă, lucru pe care, de cele mai multe ori, nu îl neglijează când merg la facultate. Totuşi, lipsa contactului vizual poate afecta climatul interac iunii din timpul videoconferin ei.

În ceea ce priveşte procesarea informa iei, o componentă esen ială a albabetizării digitale mai ales în mediul academic, doar 41,8\% declară că ştiu să folosească cu încredere motoarele de căutare online, inclusiv pentru identificarea de surse academice precum: Google Scholar, Jstore etc., acest număr fiind mai redus decât ne-am fi aşteptat.

Deşi competen ele de cetă enie digitală implică utilizarea cu încredere şi în mod critic a tehnologiei din societatea informa ională, doar $26,7 \%$ dintre responden i au declarat că pot face diferen a între o sursă de încredere, care poate fi folosită în contextul educa ional şi o sursă mai pu in de încredere, în timp ce 29,9\% 
declară că nu sunt foarte siguri că pot face diferen a. Viitorii formatori trebuie să fie creatori de con inut responsabili, pe lângă consumatorii de con inut, însă doar 14,4\% declară că pot alege cel mai potrivit program de video-conferin ă pentru o anumită activitate didactică şi doar $16,6 \%$ că pot alege cea mai potrivită aplica ie educa ională digitală pentru o anumită activitate didactică.

Având în vedere meta-competen ele de cetă enie digitală, putem afirma că tehnologia joacă un rol important în via a responden ilor. Astfel, aceştia consideră în propor ie de $49,3 \%$ că pentru a se bucura pe deplin de beneficiile tehnologice trebuie să respecte anumite norme de comportament, într-o foarte mare măsură. Totodată, ei sus in în propor ie de $50,7 \%$ că în foarte mare măsură universitatea ar trebui să promoveze valori şi norme necesare pentru o utilizare responsabilă şi adecvată a tehnologiei, depăşind chiar şi familia $(43,6 \%)$ în ceea ce priveşte acest aspect.

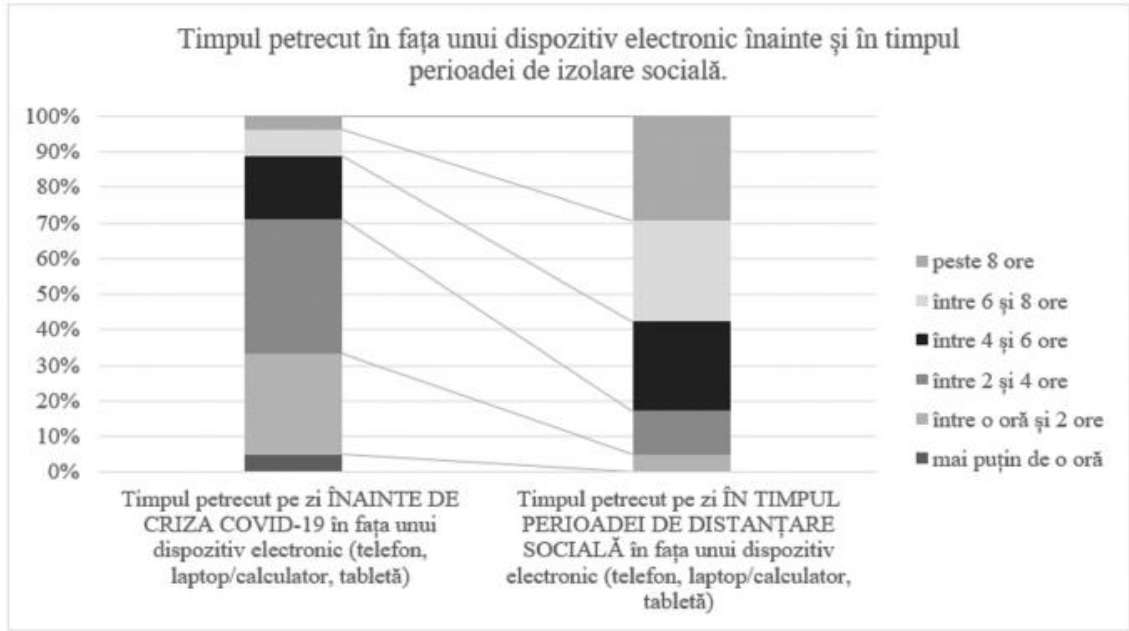

Figura nr. 5. Timpul petrecut în fa a unui dispozitiv electronic înainte şi în timpul perioadei de distan are socială

4.4. Protec ie digitală

Dimensiunea „Protec ie” în contextul cercetării noastre şi în acord cu abordarea dezvoltată de Curran şi Ribble (2017) îmbină elementele ,sănătate 
şi stare de bine digitală” şi „,drepturi şi obliga ii legale în mediul digital”. Protec ia în mediul online este un element foarte important al competen elor de cetă enie digitală, iar modul în care studen ii se raportează la acest lucru afectează atât siguran a cât şi starea lor de bine şi a celorlal i.

Analiza relevă o aten ie scăzută pentru modul în care studen ii se raportează fizic atunci când lucrează la calculator. Aceştia tind mai degrabă să nu aibă grijă cu postura lor la calculator şi manifestă comportamente care, în timp, le pot afecta sănătatea, precum lipsa utilizării scaunelor ergonomice, nerespectarea distan ei fa ă de ecran sau utilizarea inadecvată a mouse-ului şi a tastaturii. Acesta reprezintă un aspect care ridică îngrijorări, cu atât mai mult în această perioadă, când timpul petrecut în fa a calculatorului a crescut semnificativ.

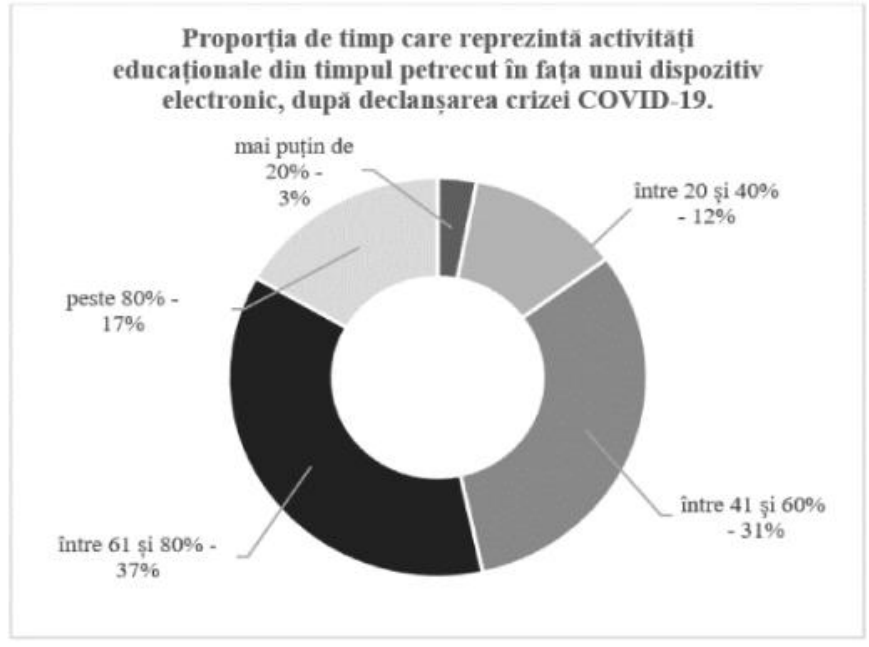

Figura nr. 6. Procent timp pentru activită i educa ionale

Dacă înainte de criza COVID-19 majoritatea studen ilor petreceau între o oră şi patru ore pe un dispozitiv electronic, pe durata pandemiei acest timp a crescut exponen ial, iar cea mai mare parte dintre studen i utilizează un dispozitiv electronic zilnic pentru o durată mai mare de 6 ore. Din acest timp, $82,2 \%$ dintre responden i afirmă că în propor ie de peste $40 \%$ îl alocă activită ilor educa ionale. Având în vedere ponderea mare de timp petrecut pe dispozitive electronice, starea de bine digitală capătă o valen ă foarte importantă. Datele 
cercetării arată o stare de bine care tinde să fie uşor afectată negativ, deoarece timpul aproape dublu pentru activită i în online din această perioadă este resim it ca fiind în mare măsură epuizant (43\%) şi stresant (34\%).

Un factor suplimentar care contribuie la diminuarea stării de bine este şi nesiguran a în utilizarea tehnologiei, o mare parte dintre studen i considerând că alte persoane se descurcă mai bine decât ei (46,8\%). În contextul actual, o tendin ă descendentă a stării de bine este de aşteptat, având în vedere faptul că studen ii declară că reuşesc, într-o mare măsură, să men ină un anumit echilibru, între via a reală şi cea virtuală şi că reuşesc să gestioneze interac iunile în mediul virtual, neavând tendin a de a se compara cu ceilal i, putându-se remarca cu această ocazie o premisă pentru consolidarea stării lor de bine în mediul online, o dată cu adaptarea la context.

Un alt aspect al dimensiunii protec iei în mediul online, pe care l-am analizat în cercetarea noastră, este cel legat de drepturi şi obliga ii legale în mediul digital, care vizează necesitatea raportării adecvate la norme pentru a ne asigura şi a facilita celorlal i siguran ă şi o stare de bine, pozitivă, în mediul online, în raport cu protec ia în acest mediu. Conform datelor din studiul nostru, studen ii în eleg într-un procent semnificativ drepturile şi obliga iile din mediul online, însă există perspective de dezvoltare în această direc ie. Un procent de $15,1 \%$ dintre studen ii afirmă că nu ştiu să facă diferen a între ac iunile legale şi ilegale din mediul online. De asemenea, un procent crescut de $32 \%$ dintre studen i se află la mijloc, remarcându-se astfel o nevoie de consolidare a cunoştin elor în această direc ie.

Când aspectele privind drepturile şi obliga iile din mediul online sunt tratate specific, observăm că studen ii în eleg în mare parte toate aceste aspecte, dar şi modul de operare pentru respectarea drepturilor. Astfel, în propor ie de 75,3\% ştiu că este ilegal să împărtăşească informa iile primite confiden ial în mediul digital, fără să aibă acordul celui care le-a distribuit. De asemenea, studen ii în eleg într-o propor ie foarte mare $(68,3 \%)$ că nu este etic să folosească con inuturile de pe internet ca şi cum ar fi personale. Acest aspect este întărit şi de faptul că $63,7 \%$ sus in că ştiu cum trebuie citată o sursă digitală şi că realizează acest lucru în activită ile lor.

Având în vedere datele anterioare, putem genera un rezultat pozitiv în vederea cunoştin elor pe care studen ii le de in în legătură cu drepturile şi obliga iile 
pe care le au în mediul digital, întrucât o mare parte dintre aceştia cunosc normele de bază şi modul în care este necesar să protejezi atât informa ia externă, cât şi modul de a opera cu aceasta, existând totuşi perspective de dezvoltare mai aprofundată în această direc ie.

Studen ii au o bază solidă privind dimensiunea protec iei în mediul online, în eleg în mare măsură drepturile şi obliga iile din mediul online şi se raportează relativ sănătos la mediul digital pentru a-şi sus ine starea de bine. Cu siguran ă, am observat că situa ia generată de criza COVID-19 a influen at negativ starea de bine a studen ilor, în special în raport cu timpul prea îndelungat petrecut pe dispozitive, timp care, conform acestora, a devenit epuizant şi stresant într-o măsură semnificativă, însă studen ii prezintă clare semne de capacitate de rezilien ă. În egală măsură, trebuie să avem în vedere faptul că responden ii sunt acei studen i care de in anumite competen e digitale şi că au avut disponibilitatea de a completa un chestionar digital, însă şi în acest context există structuri de competen e de cetă enie digitală preexistente care pot fi dezvoltate.

\section{Concluzii şi recomandări}

Rezultatele noastre sugerează că atât cunoştin ele cât şi competen ele atitudinale de cetă enie digitală ale viitorilor profesionişti în educa ie sunt relativ bune în multe domenii. Totuşi, acestea nu sunt dublate de abilită i de a ac iona în concordan ă. Acest lucru se face remarcat când vorbim de dimensiunea respectului în mediul digital, unde studen ii afirmă că pot recunoaşte situa ii violente şi problematice online (de cyber-bullying, hate speech, flaming şi zoom-bombing), dar nu sunt la fel de siguri cum ar putea ac iona pentru a le opri. O nevoie similară de a dezvolta mai bine abilită ile de a ac iona se remarcă şi în domeniul sănătă ii şi stării de bine digitale (componentă a protec iei în mediul digital). Aici rezultatele cercetării noastre arată că studen ii au tendin a de a neglija aspectele de raportare fizică la tehnologie (pozi ie corporală ergonomică etc.). Această tendin ă se face sim ită şi în dimensiunea educa iei digitale unde, de exemplu, studen ii nu de in într-o măsură satisfăcătoare abilită i de a selecta platforme educa ionale adecvate procesului didactic sau de a căuta şi identifica informa ii online prin intermediul motoarelor uzuale de căutare (inclusiv celor academice). 
Impactul măsurilor de distan are socială asupra transferării procesului educa ional către online s-a făcut puternic resim it în cadrul eşantionului studiat. Acest lucru se remarcă în primul rând în digitalizarea procesului educa ional academic - educa ia în mediul digital, de la un fenomen marginal a devenit o practică curentă şi indispensabilă. Deşi în cadrul eşantionului nostru accesul la aceste noi practici cotidiene nu a fost puternic limitat, ne punem totuşi întrebarea dacă acesta nu este un efect al distorsiunii eşantionului. Digitalizarea bruscă şi de mare amploare are şi un efect negativ, mai ales raportându-ne la dimensiunea de protec ie în mediul digital. Cu această ocazie, putem observa faptul că starea de bine a responden ilor a suferit influen e negative din cauza timpului crescut petrecut în fa a unui dispozitiv electronic, studen ii resim ind acest lucru ca fiind epuizant şi stresant. Digitalizarea bruscă a avut şi un impact pozitiv, prin crearea unor competen e de cetă enie digitală, prin învă area experien ială, datorită timpului petrecut pe platforme educa ionale online care a crescut sim itor.

În concluzie, viitorii profesionişti în educa ie au nevoie să-şi dezvolte mai bine abilită ile de a ac iona responsabil şi adecvat în mediul online, un lucru care ar putea fi mai bine încorporat în programele de studiu din domeniul ştiin elor educa iei. În acelaşi timp, perioada de distan are socială şi transferul activită ii educa ionale în mediul online pot constitui o experien ă formativă care, pe termen mediu, poate duce la dezvoltarea unei genera ii de profesionişti în educa ie cu competen e pronun ate de cetă enie digitală.

\section{Referin e}

- Consiliul Europei. (2019). Digital Citizenship Education Handbook. https://rm.coe.int/16809382f9

- Curran, M. B. F. X., \& Ribble, M. (2017). P-20 Model of Digital Citizenship. New Directions for Student Leadership, 2017(153), 35-46. https://doi.org/10.1002/yd.20228

- EUROSTAT. (2019). People with basic or above basic digital skills. https://ec.europa.eu/eurostat/web/products-eurostat-news/-/EDN-20200207-1

- Farmer, L. S. J. (2011). Teaching Digital Citizenship. Selected Topics in Education and Educational Technology, 387-392.

- Frau-Meigs, D., O’Neill, B., Soriani A., \& Tome, V. (2017). Digital citizenship education: Volume 1: Overview and new perspectives. Council of Europe.

- Hamutoğlu, N. B., \& Ünal, Y. (2015). Digital citizenship in Turkey and in the 
world: educational applications and technology. The Online Journal of Quality in Higher Education, 2(3), 39-43.

- Mali a, L., \& Grossek, G. (2019). Educa ia adul ilor pentru cetă enie digitală. In S. Sava \& R. Paloş (Eds.), Educa ia adul ilor: Baze teoretice şi repere practice. Polirom.

- Ministerul Comunica iilor şi Societă ii Informa ionale. (2015). Strategia Na ională privind Agenda Digitală pentru România. https://epale.ec.europa.eu/sites/ default/files/strategia-nationala-agenda-digitala-pentru-romania-20202c-20feb.2015.pdf

- Nordin, M. S., Ahmad, T. B. T., Zubairi, A. M., Ismail, N. A. H., Rahman, A. H. A., Trayek, F. A. A., \& Ibrahim, M. B. (2016). Psychometric Properties of a Digital Citizenship Questionnaire. International Education Studies, 9(3), 71-80. http://doi.org/10.5539/ies.v9n3p71

- Prensky, M. (2001). Digital Natives, Digital Immigrants. https://www. marcprensky.com/writing/Prensky\%20-\%20Digital\%20Natives,\%20Digital\%20 Immigrants\%20-\%20Part1.pdf

- Ribble, M., \& Bailey, G. (2007). Digital Citizenship in Schools. International Society for Technology in Education.

- Ribble, M. S., Bailey, G. D., \& Ross, T. W. (2004). Digital citizenship: Addressing appropriate technology behavior. Learning \& Leading with Technology, 32(1), 6-9.

- Suler, J. (2004). The Online Disinhibition Effect. CyberPsychology \& Behavior, 7(3), 321-326. http://doi.org/10.1089/1094931041291295

- Vuorikari, R., Punie, Y., Carretero, S., \& Van den Brande, G. (2016). DigComp 2.0: The digital competence framework for citizens. Update Phase 1: The Conceptual Reference Model. https://ec.europa.eu/jrc/en/publication/eurscientific-and-technical-research-reports/digcomp-20-digital-competenceframework-citizens-update-phase-1-conceptual-reference-model

The online version of this article can be found at: http://revped.ise.ro/category/2020-en/

\section{(CC) $\mathrm{BY}-\mathrm{NC}-\mathrm{BA}$}

This work is licensed under the Creative Commons Attribution-NonCommercial-ShareAlike 4.0 International License.

To view a copy of this license, visit http://creativecommons.org/licenses/by-nc-sa/4.0/ or send a letter to Creative Commons, PO Box 1866, Mountain View, CA 94042, USA.
Versiunea online a acestui articol poate fi găsită la: http://revped.ise.ro/category/2020-ro/

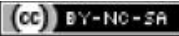

Această lucrare este licen iată sub Creative Commons Attribution-NonCommercial-ShareAlike 4.0 International License.

Pentru a vedea o copie a acestei licen e, vizita $i$ http://creativecommons.org/licenses/by-nc-sa/4.0/ sau trimite i o scrisoare către Creative Commons, PO Box 1866, Mountain View, CA 94042, SUA. 


\title{
A CRITICAL LOOK AT THE PORTFOLIO AS A TOOL FOR REFLECTIVE LEARNING: STUDENTS' PERCEPTION
}

Elena Marin*

\author{
University of Bucharest, \\ Faculty of Psychology and Educational Sciences, \\ Bucharest, Romania \\ elena.marin@fpse.unibuc.ro
}

\begin{abstract}
The new challenges faced by the future teachers make them assume a new role, that of reflective practitioner. Therefore, university programs should give future teachers the opportunity to engage in practical experiences that will stimulate their reflective skills and which can help create a strong and authentic teaching career. In this sense, a series of interventions, at a simulated level, were put into practice by the students in Pedagogy enrolled in year II at the University of Bucharest. After participating in the proposed activities, the students had to write a reflective essay. A series of focus-groups were organised in order to identify the students' opinion towards the use of a reflective essay as a way of professional training. The results show that the reflective essay is a tool that plays a significant role in building better and more meaningful learning experiences and helps in providing evidence-based methodological decisions.
\end{abstract}

Keywords: pre-service teachers, portfolio, reflective practice, university.

\section{Rezumat}

Noile provocări cu care se confruntă viitorii profesori îi determină să-şi asume un nou rol, acela de practician reflectiv. De aceea, programele universitare ar trebui să le ofere viitoarelor cadre didactice oportunitatea de a se implica în experien e practice, care le vor stimula abilită ile de reflec ie şi care pot ajuta la crearea

* Lecturer, PhD, Faculty of Psychology and Educational Sciences, University of Bucharest, Bucharest, Romania. 
unei cariere didactice autentice. In acest sens, o serie de interven ii, la nivel simulativ, au fost puse în practică de către studen ii înscrişi în anul II la programul de studiu Pedagogie de la Universitatea din Bucureşti. După participarea la activită ile propuse, studen ii au avut de redactat un eseu reflectiv. O serie de focus-grupuri au fost realizate cu scopul de a identifica atitudinile şi opiniile studen ilor/viitorilor profesori despre utilizarea unui eseu reflectiv ca o modalitate de formare profesională. Rezultatele arată că eseul reflectiv este un instrument care are un rol semnificativ în construirea unor experien e de învă are mai bune şi mai semnificative şi ajută la furnizarea de decizii metodologice bazate pe dovezi.

Cuvinte-cheie: portofoliu, practică reflectivă, universitate, viitori profesori.

\section{Introduction}

The international movement to reform teaching and improve the quality of education started by OECD (OECD, 1989) was based on the John Dewey's philosophy that emphasizes reflection as a deliberate and active process. As Dewey stated, reflection is an 'active, persistent and careful consideration of any belief or supposed form of knowledge and further conclusions to which it leads' (Dewey, 1933, p. 118). Reflection has been included in initial teacher training study programmes as part of a mandatory competency in many universities. In the new education paradigm, reflection is seen as an important aspect whose aim is to support the transition from a teacher training system that is based on competence towards a more professionally-oriented teacher training system.

This change is due to the new challenges that prospective teachers face and to the need to assume a new role calling for other skills than the subject matter (Eurydice, 2002). Particularly, these skills target the ability to critically reflect with an emphasis on the ability to link theory and practice and create and make use of specific strategies in order to deal with different and innovative learning situations, as well as develop an 'understanding of what they actually did know and also how the knowledge has been acquired' (Sultana, 2005, p.14).

Taking into consideration all these shifts that put a greater emphasis on the professional development of pre-service teachers rather than on their level of knowing and using information from their subject area, it seems natural to 
focus on developing a cognitive stimulating process based on the use of a reflective portfolio. The reflective portfolio is seen as a tool which would allow pre-service teachers to participate in critical reflection and lead to further learning. In this respect, Klenowski (2000) portrays reflective teachers as self-directed professionals that have the capacity to question, frame and resolve dilemmas of classroom practice, while Lyons regards the use of portfolios in assessment as a move towards a 'new professionalism' in teaching that has the potential to foster 'collaborative, interpretive communities of teacher learners who can interrogate critically their practice and uncover and make public what counts as effective teaching in today's complex world of schools and learners' (Lyons, 1998, p. 20).

\section{Reflective learning as a key concept in the teacher training programme}

Even though reflective learning is recognized by lots of professions to be an important tool for growth and development (Marzano, 2012), there is a lack of common vision regarding its value and its limitations in the literature. As presented in Dewey's work (1933), reflection provides the perfect background for discovery, argumentation, belief-disclosure, internalization of principles, all of these which are drawn from their learning experience. Moreover, Richards and Lockhart (1994) argue that reflective learning aims at examining the teaching experience as a source for change.

A constructivist view on the initial teacher training system, sees reflective practices and evidence-based training as an important asset for the $21^{\text {st }}$ century learners. However, reflection, regardless of its form, can produce change only if it is used in a systematic way, in a cyclical and spiraling process (Pollard, 2008).

As many educationalists agree, reflection is a process that is directly related to critical thinking, looking deep at an act or experience from the memory and trying to remember the details that can be connected to this particular event. Remembering the event and retrieving all the small details, just as a guided process, can facilitate the learning process to be more fruitful and more meaningful (Gough, 2007; Pollard, 2008; Richards \& Lockhart, 1994). 
Due to its multiple use, reflection can be considered vital in the teacher training programme. As Costa and Kallick (2000) state, reflection can support teacher learning through: promoting new understanding of their work through the insights of others; supporting teachers in making commitment to plans and innovations; documenting learning to provide a wide opportunity for shared knowledge. Several authors (Brockbank \& McGill, 2007; Henderson et al., 2004; Van Woerkom, 2010) concur that reflective practice strengthens values such as sustaining a better understanding or the process of deep learning; enables students to understand their own process of learning; helps students to development professionalism; helps put an emphasis on the process of constructing, deconstructing, and reconstructing knowledge based on rich learning experiences; ensure that the learning process is not restricted to formal settings only; helps create an authentic learning environment that is essential for deep learning (Iucu \& Marin, 2014).

\section{The importance of the reflective portfolio in the pre- service teacher training programme}

Yasin et al. (2012) show that the portfolio can also give evidence on the developmental process of each student. Zubizarreta (2004) sees the portfolio as a reflexive, evidence-based process that merged two important processes - the reflection and research process and, at the same time, emphasizes the importance of collaborative analysis of their own learning and their experiences that are related to a certain topic. More specifically, in preservice teacher education programmes, portfolios have multiple purposes starting with giving pre-service teachers the option to make up their personal philosophy regarding the teaching process (Hildebrand, 2005); also provides the chance to document his/her learning experiences (Loughran \& Corrigan, 1995); can boost pre-service teachers process of reflection on his/her individual strengths and weaknesses, leading to personal growth and development (Klenowski, 2000); encourages pre-service teachers to document and describe their skills and competence as teachers (Mosely, 2005); promotes student learning, professional development and reflection, as well as provides evidence for evaluation (Stone, 1998); and last but not least, it can be seen as a 'showcase' document that provides perspective on the teaching and learning achievements of the pre-service teachers and 
valuable insights for a prospective employer (Andrews et al., 2002). Berrill and Whalen (2007) see portfolios as a way to support a more focused reflection, instead of a vaguer thinking about internal learning experiences. Thus the portfolio becomes an important tool for empowering pre-service teachers to take control of their own learning process (Marin, 2015). As seen above, the advantages of using portfolio are wide, but McMullan et al. (2003) note that while the 'summative' aspect of the portfolio undermines student ownership, pre-service teachers did not give value to the portfolio unless they were going to get some credit for having completed it.

All in all, we can conclude that portfolios are a tool that students can use in order to develop reflective practice, especially in their pre-service teacher training; it provides pre-service teachers with a summative document outlining their achievements and a means to perceive themselves as future professionals (Chetcuti, 2007).

\section{Methodology}

\subsection{Methods}

The methodology used in this study consists of focus-groups developed at the end of the university course after pre-service teachers had gone through a full semester of teaching simulation. The focus-groups were organised yearly, for 4 years, when the course ended. The focus-group study aims:

- to identify the attitudes and beliefs of pre-service teachers with respect to the use of the reflective portfolio;

- to find out how relevant the reflective portfolio is for the pre-service teachers;

- to identify the pre-service teachers' autonomy during the process of reflection;

- to identify the benefits of using reflection activities in their future teaching career.

The focus-groups lasted approximately 60 minutes each. Then the transcribing and analyzing process began by using a coding system. The coding system is based on the theoretical framework developed during the literature review. 
In order to facilitate coding, the Maxqda 11 software was used so all the respondents' quotations were introduced and patterns were identified across different responses. The interviewers are identified by code, from I1 to I56.

\subsection{Participants}

A group of pre-service teachers $(n=56)$ representing students enrolled in their $2^{\text {nd }}$ year of study and finalizing their compulsory course (i.e., Classroom management) participated at these focus-groups. The structure of this course is based on a series of teaching activities that pre-service teachers must plan in groups, organize into the least details, put into practice and then evaluate their performance. Every teaching activity is based on the six dimensions of the classroom management as described by Iucu (2006): ergonomic, psychological, sociological, operational, normative and innovative classroom dimensions. Apart from planning a teaching activity, students have the task to write a reflective portfolio where they write their own reflection on the respective learning activity. On the one hand, we have pre-service teachers that prepare and implement a teaching activity and, on the other hand, we have pre-service teachers that observe their colleagues delivering a teaching activity. This provides pre-service teachers to a unique opportunity to develop a broader understanding of the process of teaching. The sample does not reflect the general population or appropriate population of students, but it is relevant for the institution in which this research was developed.

\section{Results}

5.1. Pre-service teachers' attitudes and beliefs about the reflective portfolio seen as a way to develop understanding through reflection

The aim of the reflective portfolio is to help students make connections to theories or to their own experiences while emphasizing their attention on how to use concepts related to the teaching and learning subject. While interviewing students on the relevance of portfolio as a way to acquire knowledge, three main aspects arose. The first one is related to the possibility of helping student to have a better understanding of what they really know 
and helping them to identify possible gaps. Also, another goal was to help students identify the benefits of the process of writing a reflective portfolio. First, students were faced with looking introspectively at what they know, what is the information they lack or the information that is somehow not deeply understood. One student agrees that:

'Being a process that spread through an entire semester there was a lot of time to start writing and putting into words the ideas that I had, related to the course, but somehow, mostly at the beginning of the course, I found myself not being able to express my ideas in the way that I wanted, and this was due to the fact that I lacked content and was not too familiar with the terminology.' (I23)

The process of writing a reflective portfolio is seen as an ongoing process that helps students to discover their gaps, with an emphasis on constructing a clear discourse. One interviewer agrees that:

'This inability to use terminology may show a lack of content mastery and furthermore can make the crucial difference between a professional in this field of classroom management and an amateur that expresses an opinion without having any theoretical background to sustain his/her arguments.' (I8)

Another aspect was related to pre-service teachers' autonomy in the learning process that is seen as the ability to keep a high level of motivation. In this respect, one interview stated that:

'The writing process of the reflective portfolio was overwhelming, I began with writing my beliefs which allowed me to express what teaching means for me, I don't think I had this opportunity before, and most importantly, it has encouraged me to continue with an innovative and energetic approach to improve and try to overcome my current teaching skills.' (I8)

Even though the process of improving our own teaching skills is mostly a personal one, the process of reflecting can have a boost from peer discussions. Also, it provides with a great opportunity to highlight some strengths and weaknesses that may interfere in teaching practices. Sustaining the ideas presented above, students stated that:

'This task went beyond just being a classroom task for which I would 
get a grade, for me it meant that I had to reflect on my personal beliefs and values, as well as my still <under the process> teaching skills [...] I strongly believe that reflective portfolios, though not an easy task, represent an essential tool that not only can help students to put in order and to give a clearer picture of what are their strengths and weaknesses when it comes not only to have a solid knowledge, but on the process of translating that knowledge into practice, when you start teaching. Also, I would like to bring into discussion the fact that the reflective portfolio can go beyond our university learning and can also be considered an important asset in the ongoing process of workplace learning and reflection on one's career.' (I32)

If the idea above is more thoroughly explored, it seems that there is a correlation between the process of reflection and the growth of the school community as a learning community. The school community, represented mainly by teachers, have to put pressure on the process of reflection on its own or as a group.

If the process of reflective thinking becomes a routine in the teaching career, it could be a step forward in the process of constantly improving teaching skills and also can be a useful tool to showcase the positive aspects and achievements of the teaching career that can increase job motivation, leading to the closing of the teacher gap as it is presented in the UNESCO report (UNESCO, 2016).

The third aspect brought into discussion during the focus-groups was the fact that the portfolio can be used in order to gather evidence that can help and support a better understanding of what it means to construct a fruitful teaching career in the $21^{\text {st }}$ century. Having a wide range of reflective portfolios that focus on different aspects of the teaching career can offer us the possibility to create a bank of experiences that teacher students go through and this can be seen as extremely useful in the process of updating and upgrading the teacher training programmes.

5.2. The level of autonomy of the pre-service teachers within the reflective process

The first aspect worth mentioning when talking about the pre-service teacher's 
autonomy level in handling the reflective process is the impact that the reflective portfolio has on promoting autonomous learning. In this respect, the process of sitting back and reflecting on the good practices that you can draw from the experience of observing someone's teaching or from evaluating your own teaching experience can have a great impact on the continuous professional development and growth as a professional in the educational field. One interviewee replied:

'The most important thing was realizing that my learning process depends mostly on myself and, because I am such a critical evaluator, I found out that sometimes I get stuck on going on and on through events that influenced my teaching [...] but overall it helped me consciously create my own educational philosophy.' (I13)

But too much autonomy during this process of professional development can have some negative impact on improving your teaching practices. For example, having too little direction from the coordinator may lead to a superficial reflection while writing a portfolio. Thus, the reflective portfolio will just simply be seen as a report, just as an interviewee observed:

'At the beginning, I wasn't used to thoroughly go through my learning process, so it was easier for me to just write the portfolio by describing that I did this and this and this [...] without having any valuable comments about what I really focused on, what worked and what did not, what students actually learn or what they will be able to do in the future based on what they have learned within this lesson.' (I34)

Moreover, having the autonomy to decide about the management of writing the reflective portfolio triggered some time management issues for these students. For them, the process of writing a reflective portfolio was somehow difficult due to the fact that they could not find the proper words to start writing and this information is supported by an interviewee who agrees that: 'The portfolio took many hours of preparation and searching, but mostly it took a lot of courage to start writing because I have the feeling that nothing special happened during the teaching process' (I51) or 'For me, the starting of the writing process was so painful because I would start writing, but after reading what I had written I immediately found it irrelevant and somehow feeling embarrassed 
of what I had written [...] maybe the presence of a tutor that asked for our pieces of writing to look over them and give us feedback more often could have helped me overcome this insecurity'. (I47)

5.3. Possible benefits from using this tool in future teaching career

The teaching career has and always will be an increasingly important aspect, as Europe constantly tries to address its educational, social and economic challenges. As pointed out in the Teaching Careers in Europe: Access, Progression and Support Report launched by the European Commission in 2018, teaching today focuses on lifelong career development, while adapting to new challenges, and collaborating with peers and does not forget the importance of using new technologies in the learning process. The teaching career is constantly changing and teachers 'need policy reforms in order to be able to respond proactively to the new requests' (European Commission, 2018). But in order to have strong and relevant policy reforms we have to deeply understand the dimensions of the teaching career. And what a better way to do this than by reflection. That is why we asked the participants of this study to think and evaluate the possible benefits that a reflective portfolio can bring in terms of their future teaching career. One of the main things which stands out is that this tool can help future teachers have a clearer and more objective perspective on their professional pathway:

'This tool enabled me to be very objective and to honestly think at the idea if this career is really for me, if I see myself doing this for the next 10 or more years on.' (I31)

Meanwhile, other respondents emphasized the experience of writing a reflective portfolio as a meaningful yet difficult process by:

'... critically evaluate myself as a future teacher but as I thought more about what works and what doesn't, for me as a teacher, I began to relax a little bit and allow myself to learn from my own mistakes; it was a hard period, of admitting that being good in one field does not necessary mean that you can teach that subject.' (I9)

Still, other interviewed students started this reflection journey from a positive perspective, showcasing the advantages and focusing on the process of 
learning and discovering the mysterious pathways into the teaching career: 'Reflecting back and forth was actually the most rewarding and helpful process because it enabled me to question what I was really doing, something that most teachers have insufficient time to do.' (I13)

Maybe one of the most important ideas that was identified by the interviewed students was the fact that it is not only important to reflect critically on personal and professional experiences, but also explore how these experiences can be translated into methodological decisions, further reflection that can be the activator of starting to build a community of practice amongst other teacher colleagues.

\section{Conclusions}

In this article we explored pre-service teachers' perspective regarding the importance of the process of writing a reflective portfolio. One main aspect that comes into light when talking about the use of a reflective portfolio is related to the opportunities that the students may have to identify their tacit knowledge and at the same time to identify the gaps in that knowledge, while being faced to look introspectively at what they know, what are the information they lack or the information that is somehow not deeply understood. Being able to reflect on your own level of understanding a subject can help you as a future teacher by supporting others to discover and better understand their own learning process. In other words, the results confirm previous studies that showed that being able to engage in a true and authentic reflection process can have an immediate impact on current and future classroom practices, sustaining the improvement of developing new practices (Russell, 1999).

Also, within this study, another relevant result focused on bringing into discussion the fact that the portfolio can be used in order to gather evidence that can help and support a better understanding of what it means to be a teacher-researcher, just as various researchers (Girod \& Pardales, 2001; Mills, 2000) revealed in their studies. Moreover, looking at the impact on the class and effects on the positive educational change that this practice of 
reflective portfolio use can bring, the results correlate with the findings that several authors declared in their studies (Mertler \& Charles, 2008; Wink, 2018) showing that having a critical perspective on your work does not only give you a clear image of your achievements, but it can also help you develop a better understanding of your learning process.

In terms of level of autonomy of the pre-service teachers that engaged in writing a reflective portfolio, it is believed that the process of sitting back and reflect on the good practices that you can draw from the experience of observing someone's teaching or from evaluating your own teaching experience can have a great impact on the continuous professional development. Other studies (Hariprasetya, 2017; Vangrieken, 2017) showed that the process of writing a reflective portfolio promotes growth as a professional in the educational field by enabling pre-service teacher's autonomy and collaborative attitude.

From a systematic point of view, the portfolio can be seen as a tool to gather evidence that can help and support a better understanding of what it means and what are the key elements which sustain the development of a fruitful teaching career in the $21^{\text {st }}$ century. Using the data that prove the importance of reflective portfolios, teacher training programmes can open the possibility to create a bank of experiences that teacher students go through and this can be seen as extremely useful in the process of updating and upgrading the existing teacher training programmes.

In conclusion, we strongly rely on the idea that it is not only important to critically reflect on personal and professional experiences, but also to explore how this experiences can be translated into methodological decisions, further reflection that can be the activator of starting to build a community of practice among the school community (Fry \& Venneman, 2018; Wang, 2018).

\section{References}

- Andrews, S., Ducharme, A., \& Cox, C. (2002). Development and use of electronic portfolios in preservice education. In Society for Information Technology \& Teacher Education International Conference (pp. 528-530). Association for 
the Advancement of Computing in Education (AACE).

- Berrill, D. P., \& Whalen, C. (2007). "Where are the children?” Personal integrity and reflective teaching portfolios. Teaching and Teacher Education, 23(6), 868884. https://doi.org/10.1016/j.tate.2007.02.002

- Brockbank, A., \& McGill, I. (2007). Facilitating Reflective Learning in Higher Education. McGraw Hill.

- Chetcuti, D. (2007). The use of portfolios as a reflective learning tool in initial teacher education: a Maltese case study. Reflective Practice: International and Multidisciplinary Perspectives, 8(1), 137-149.

http://dx.doi.org/10.1080/14623940601139111

- Costa, A. L., \& Kallick, B. (2000). Discovering and exploring habits of mind. Explorations in Teacher Education, 36.

- Dewey, J. (1933). How We Think: A Restatement of the relation of Reflective Thinking to the Educative Process. Henry Regnery Comp.

- European Commission/EACEA/Eurydice. (2018). Teaching Careers in Europe: Access, Progression and Support. Eurydice Report. Publications Office of the European Union. http://dx.doi.org/10.2797/309510

- Eurydice. (2002). The teaching profession in Europe: Profile trends and concerns: Report 1: Initial training and transition to working life. Eurydice.

- Fry, J., Klages, C., \& Venneman, S. (2018). Using a written journal technique to enhance inquiry-based reflection about teaching. Reading Improvement, 55(1), $39-48$.

- Girod, M., \& Pardales, M. (2002). Who am I becoming? Identity development in becoming a teacher-researcher [Paper presentation]. Annual Meeting of the American Educational Research Association 2001, Seattle, USA.

- Gough, D. (2007). Weight of Evidence: A Framework for the Appraisal of the Quality and Relevance of Evidence. In J. Furlong \& A. Oancea (Eds.), Applied and Practice-based Reasearch. Special Edition of Research Papers in Education, 22(2), 213-228. http://dx.doi.org/10.1080/02671520701296189

- Hariprasetya, A., Wiyono, B. B., Imron, A., \& Arifin, I. (2017). The relationship of academic supervision, educational profession insentive and teacher competence with teacher performance at the performing middle schools in Malange, East Java, Indonesia. Journal of Social Sciences (COES\&RJ-JSS), 5, 595-605.

- Henderson, K., Napan, K., \& Monteiro, S. (2004). Encouraging reflective learning: An online challenge. In R. Atkinson, C. McBeath, D. Jonas- Dwyer \& R. Philips (Eds.), Beyond the comfort zone: Proceedings of the 21 st ASCILITE Conference (pp. 357-364). Perth.

- Hildebrand, V. (2005). Returns to education in the European Union: a reassessment from comparative data. European journal of education, 40(1), 13-34.

- Iucu, R. (2006). Managementul clasei de elevi. Aplica ii pentru gestionarea situa iilor de criză educa ională ( $2^{\text {nd }}$ ed.). Polirom. 
- Iucu, R., \& Marin, E. (2014). Authentic Learning in Adult Education. ProcediaSocial and Behavioral Sciences, 142, 410-415.

- Klenowski, V. (2000). Portfolios: promoting teaching. Assessment in Education: Principles, Policy \& Practice, 7(2), 215-237. https://doi.org/10.1080/713613329

- Loughran, J., \& Corrigan, D. (1995). Teaching portfolios: A strategy for developing learning and teaching in preservice education. Teaching and teacher Education, 11(6), 565-577. https://doi.org/10.1016/0742-051X(95)00012-9

- Lyons, N. (1998). With portfolio in hand: validating the new teacher professionalism. Teacher College Press.

- Marin, E. (2015). Experiential Learning: Empowering Students to Take Control of Their Learning by Engaging Them in an Interactive Course Simulation Environment. Procedia-Social and Behavioral Sciences, 180, 854-859. http://dx.doi.org/10.1016/j.sbspro.2015.02.224

- Marzano, R. (Ed.). (2012). Becoming a Reflective Teacher. Marzano Research.

- McMullan, M., Endacott, R., Gray, M. A., Jasper, M., Miller, C. M., Scholes, J., \& Webb, C. (2003). Portfolios and assessment of competence: a review of the literature. Journal of Advanced Nursing, 41(3), 283-294. https://doi.org/10.1046/j.1365-2648.2003.02528.x

- Mertler, C. A., \& Charles, C. M. (2008). Introduction to education research $\left(6^{\text {th }}\right.$ ed.). Pearson.

- Mills, G. E. (2000). Action research: A guide for the teacher researcher. PrenticeHall, Inc.

- Mosely, C. (2005). The Value of Professional Teaching Portfolios to Prospective Employers: School Administrators' Views. Professional Educator, 27, 58-72.

- OECD. (1989). School and quality: an international report. Paris.

- Pollard, A. (Ed.). (2008). Reflective Practice: Evidence-informed Professional Practice. Continuum.

- Richards, J. C., \& Lockhart, C. (1994). Reflective Teaching in Second Language Classroom. University Press.

- Russell, T. (1999). The challenge of change in teaching and teacher education. In J. R. Baird (Ed.), Reflecting, teaching, learning. Perspectives on educational improvement (pp. 219-238). Hawker Brownlow Education.

- Stone, B. A. (1998). Problems, pitfalls, and benefits of portfolios. Teacher Education Quarterly, 21(1), 105-114.

- Sultana, R. G. (2005). The initial education of high school teachers: A critical review of major issues and trends. Studying Teacher Education, 1(2), 225-243. https://doi.org/10.1080/17425960500288390

- UNESCO. (2016). Education 2030: Towards inclusive and equitable quality education and lifelong learning for all (Incheon Declaration and Framework for Action). http://unesdoc.unesco.org/images/0024/002456/245656e.pdf.

- Van Woerkom, M. (2010). Critical Reflection as a Rationalistic Ideal. Adult 
Education Quarterly, 60(4), 339-356. http://dx.doi.org/10.1177/0741713609358446

- Vangrieken, K., Meredith, C., Packer, T., \& Kyndt, E. (2017). Teacher communities as a context for professional development: A systematic review. Teaching and teacher education, 61, 47-59. https://doi.org/10.1016/j.tate.2016.10.001

- Wang, L. (2018). On the Content of the Pre-service Teachers' Teaching Reflection in the Practicum. Theory and Practice in Language Studies, 8(9), 1195-1199. http://dx.doi.org/10.17507/tpls.0809.13

- Wink, D. J., Gane, B. D., Ko, M.-L., George, M., Zeller, L., Goldman, S. R., Pellegrino, J. W., \& Kang, R. (2018). Developing interdisciplinary competencies for science teaching and learning: A teacher-researcher professional learning community. Proceedings of International Conference of the Learning Sciences, ICLS, 3(2018), 1521-1522.

- Yasin, R. M., Rahman, S., \& Ahmad, A. R. (2012). Framework for reflective learning using portfolios in pre-service teacher training. Procedia-Social and Behavioral Sciences, 46, 3837-3841. http://dx.doi.org/10.1016/j.sbspro.2012.06.156

- Zubizarreta, J. (2004). The learning portfolio: Reflective practice for improving student learning. Anker.

The online version of this article can be found at: http://revped.ise.ro/category/2020-en/

\section{(oc) BY-NC-SA}

This work is licensed under the Creative Commons Attribution-NonCommercial-ShareAlike 4.0 International License.

To view a copy of this license, visit http://creativecommons.org/licenses/by-nc-sa/4.0/ or send a letter to Creative Commons, PO Box 1866, Mountain View, CA 94042, USA.
Versiunea online a acestui articol poate fi găsită la: http://revped.ise.ro/category/2020-ro/

\section{(cc) BY-NC-sh}

Această lucrare este licen iată sub Creative Commons Attribution-NonCommercial-ShareAlike 4.0 International License.

Pentru a vedea o copie a acestei licen e, vizita $i$ http://creativecommons.org/licenses/by-nc-sa/4.0/ sau trimite i o scrisoare către Creative Commons, PO Box 1866, Mountain View, CA 94042, SUA. 



\title{
THE EFFECTS OF EXTRACURRICULAR AND EXTRASCHOOL ACTIVITIES ON SCHOOL PERFORMANCE
}

\section{Andrea Barabás*}

\author{
University of Debrecen, \\ Doctoral School of Human Sciences, \\ Debrecen, Hungary \\ andrea.barabas17@gmail.com
}

\begin{abstract}
The socio-economical background of the family influences the school efficiency, but beside this, many other factors have outstanding effect on pupils' results. Most of these factors can be found outside of the educational institutions. The studies which focus on the performance of schooling highlight the idea that extracurricular activities have enormous benefits on the school performance as well as on the overcoming of school failure and abandonment. Our research is focusing on the extracurricular and extraschool activities as well as their effect on the development of competencies. We would like to find out how the extracurricular/ extraschool activities influence the results of competence measurements. We created our background questionnaires, that analyse the effects of influencing factors, since there aren't such questionnaires in the national assesments in Romania. Our study is based on the analysis of the KOV-ET-OM-2017 database $(\mathrm{N}=1054)$, which contains the results of the competency assesment of the 4th grade students belonging of the Hungarian minority from Covasna county and information related to contextual factors from the background questionnaires. The outcome of the research highlights the fact that the extracurricular activities have beneficial effect on the development of the school competences. Among the activities organized by the schools, the camps and the activities supporting the prodigies seem to be the most effective.
\end{abstract}

Keywords: afterschool, extracurricular activities, extraschool activities, school performance.

PhD Candidate, University of Debrecen, Doctoral School of Human Sciences, Debrecen, Hungary. 


\section{Rezumat}

Situa ia socio-economică a familiei influen ează foarte mult performan a şcolară, insă şi al i factori au efecte asupra rezultatelor şcolare. Studiile eviden iază că activită ile extraşcolare şi extracurriculare au beneficii asupra performan ei şcolare, precum şi asupra depăşirii eşecului şi a abandonului şcolar. Cercetarea noastră se concentrează pe studierea efectelor activită ilor extracurriculare şi extrașcolare asupra rezultatelor de la evaluările na ionale de la clasa a 4-a. Intrucât evaluările na ionale nu sunt înso ite de chestionare informative, nu cunoaştem impactul factorilor contextuali asupra rezultatelor elevilor. De aceea, am creat un chestionar care să ne ajute în identificarea factorilor ce influen ează performan a şcolară a elevilor. In acest studiu ne concentrăm pe analiza bazei de date KOV-ET-OM-2017, care con ine rezultatele evaluării competen elor elevilor din clasa a 4-a cu predare în limba minorită ilor maghiare $(N=1054)$ din jude ul Covasna şi informa ii legate de factorii contextuali. Rezultatele cercetării eviden iază faptul că activită ile extraşcolare au efect benefic asupra dezvoltării competen elor şcolare. Dintre activită ile extracurriculare organizate de şcoală se observă efectul pozitiv al taberelor şi activită ilor de dezvoltare.

Cuvinte-cheie: activită i extracurriculare, activită i extraşcolare, afterschool, performan ă şcolară.

\section{Introduction}

International measurements of PISA, PIRLS or TIMSS highlight the strong influence of family background and the fact that Romanian students perform more below average (Singer, 2013). In schools where the proportion of disadvantaged pupils is high, teachers make parents responsible for their child's failure at school (Fehérvári, 2015; Széll, 2015). Students with a poorer socio-economic background often perform poorly. In many places, however, the school would increase the differences from the social background (Fehérvári, 2015; Széll, 2015). In educational contexts where the parent is unable to help the child prepare for the afternoon, the school has an important role to play in increasing student achievement. Positive effects of teachers' well-functioning professional relationships and cooperation can be demonstrated in examining student performance (Bacskai, 2015). In addition to the appropriate teacher attitude, preparedness and quality of classroom activities, extracurricular activities can make a major contribution to academic achievement (Pusztai, 2015), the prevention of early school leaving (MEN- 
MB, 2015ํ) and more successful further education (Széll, 2015).

The use of the results of national competency assessments raises many questions. Although national measurements are taken at the end of grades 2 and 6, feedback is used for individual assessment and is designed to improve student performance and should be used to develop individual learning plans based on the type and amount of defective or unresolved tasks. It is beneficial because it can be motivating for the learner as he/she receives a personalized assessment. But it has little informativeness (Buda, 2011). The most important goal of competency measurement at the end of fourth grade is to evaluate lower-level education - "benchmark student performance against curriculum requirements, measure individual student performance against national average, determine performance improvement attributable to preparatory class introduction, and comparing it with the results of international measurements" (Szántó, 2015, p. 2). It should be mentioned that, while in the international measurements background factors play a central role in the analysis, in Romania there is no background questionnaire focusing on the influencing factors.

In our study, we investigate the relationship between extracurricular, extraschool activities and the result of competence measurements.

There are many definitions in the scientific literature that define activities beyond the boundaries of the curriculum. Thus, in extracurricular activities, we can meet the concepts like all-day school, full-day school, after school, second school, shadow education, which very often overlap or complement each other.

Extracurricular and extraschool activities can produce many positive effects. Part of them are correction, catch-up, compensatory programs, which are used to fill gaps in classroom and overcome social handicaps, the other part is aimed at developing sports activities, physical education, the third type is music literacy, the fourth type is participation in school life, the fifth type is religious or charitable education. The positive impact of extracurricular and extraschool activities in sport, art and science can be directly demonstrated by improved academic performance and successful admission examinations (Pusztai, 2009). 
Extracurricular activities organized in schools are characterized by organized circumstances, multiple purposes and supervision by teachers. They can be nationally sponsored, local initiatives or even organized by schools. Extraschool activities can be varied in their added pedagogical value. Countries that implement systematic school-based programs based on research results can really benefit from these ( $F$ z, 2017). There are studies that show that the extracurricular effect is particularly evident in underperforming students who need correction and compensation (Imre, 2015).

However, we must not forget the fact that coaching, pre-admission, special clubs, camps, excursions, cultural programs are increasingly found in shadow education more than in the extracurricular field within educational institutions.

\subsection{Extracurricular activities}

Báthory (1997) identifies the learning outside school and within school walls as arenas of learning. Within the school, he distinguishes between the curriculum and the extracurricular. The former focuses on curricular learning and the latter refers to learning outside the classroom but within the school walls. It emphasizes the importance of the extracurricular, as it is a proven fact that motivation to learning is not achieved through classroom learning alone. Classroom learning can be completed with other forms and spaces like libraries, laboratories, workshops. In Hungary, the introduction of optional activities has allowed the removal of rigid boundaries and has enabled students, at their choice, to deepen, supplement or even explore new areas of study.

Similar activities can be organized within the framework curriculum hours, which appear as an optional ('optional') subject as part of the local curriculum (Fóris-Ferenczi, 2008; Péter, 2012). In the international research there is a field of specialization that can be regarded as an enrichment program supporting middle-class students rather than as an extracurricular form of training for outstanding students (Gordon Gy ri, 1998). An important feature of talented pupils' development activities is that students can meet peers with similar interests and abilities. These can help them to judge their abilities 
more realistically (Páskuné Kiss, 2014). At the same time, we emphasize that specialization, corrective / compensatory activities and talent development activities help to enhance learning motivation and student performance. In Hungary, religious and community building, sports activities are predominant in church-maintained schools. For those working in these educational institutions, this is a task that requires more preparation and volunteering. Public education focuses mainly on school-related programs. Weekend programs and day trips are much more common in church institutions (Pusztai, 2009).

However, their impact on social skills is only significant if extracurricular activities are regular, lasting, and involve students in collaborative tasks ( $\mathrm{F} \mathrm{z}$, 2018).

\subsection{The all-day school}

The social changes of the last 30 years have confronted educational institutions with new challenges. Increased involvement of parents in the labor market has created a situation in which those who work spend a significant part of their day at work; the number of parents who are unemployed is constantly increasing; the multi-generational, collaborative family model disappears. Globally, it has become necessary to develop and operate a new type of parenting model, integrating and synthesizing the efforts previously pursued by educational institutions and families. In several countries initiatives taken to improve efficiency include the introduction of a all-day school. The allday school aims to achieve equal opportunities so that all children have access to services, some of which can be found in profit-oriented shadow education. Its characteristics distinguish it from programs organized after other classes, as they offer more than one activity (for example, homework solving, art, sports, leisure activities). By merely supplementing what is learned at school, if the activity is purely homework, its beneficial effects are diminished or even eliminated (Darvas \& Kende, 2010; Imre et al., 2015).

The all-day school focuses on making the school with quality classroom and leisure content more efficient. It is part of the development of the education system, but without other pedagogical and infrastructural improvements, it 
alone cannot provide a solution. In most cases, initiatives to extend time frames are not just learning time, school tasks and roles are also often transformed and the relationship between the school and its environment is also reconsidered (Imre et al., 2015). Teacher cooperation is more common in disadvantaged schools where teachers spend more time developing and catching up in order to develop individual students (Bacskai, 2015). It should also be noted that the individual's use of personalized methods (Mihály, 2004) is highly attributed to the effectiveness of teacher work.

Extending teaching time serves a variety of purposes: it can serve to strengthen socialization, increase school performance, and compensate for drawbacks stemming from disadvantage (Imre et al., 2015). The all-day school can be an important institution in overcoming disadvantages and increasing equal opportunities if its content, quality and standard are appropriate (Darvas \& Kende, 2009).

In Romania, the methodology for organizing the 'School after school' program provides the legal framework for organizing the programs. In 2017, methodological changes and additions were made to this methodology. Accordingly, the 'School after School' program is a supplementary compulsory education program aimed at: prevention of early school leaving, increasing school performance, recovery, accelerating the learning process through various learning, educational and recreational activities, personal development, promoting social inclusion; organizing the students' afternoon program in a secure space. The program is open to children in primary and secondary schools, with special attention to vulnerable children. The program is organized by educational institutions in the form of a project based on an assessment of the needs of stakeholders (students, parents, teachers, local community and partner organizations/foundations). Each educational institution must have developed the Operating Regulations for the 'School after school' program ${ }^{2}$. Education and leisure activities are aimed at personal development and social inclusion. However, educational institutions are not obliged to organize an after-school program after school, but in many cases schools do so. The school can do it with parental support, sponsorship, own income, various applications. In schools with a low socio-economic status, county and local governments, foundations and associations support the 'School after School' program. 
In Covasna County this works with the support of the county local government, through applications and sponsored by parents. In order to help children from disadvantaged families, municipalities also provide lunch to students in need. Qualified educators help with the afternoon activities: students solve their homework, participate in teambuilding games and group activities (https://www.kvmt.ro/index.php). Research results show that where there is a possibility to participate in other extra activities throughout the day (special clubs, sports activities, cultural and artistic activities, correction and compensation programs), there is a clear positive effect as opposed to simply preparing for the next day (Darvas \& Kende, 2010; Imre et al., 2015; Pusztai, 2015).

\subsection{The extraschool activities and the shadow education}

Today, there is a worldwide expansion of shadow education. Many people attribute this to the decline in the quality of formal education worldwide and the economic austerity in education. Others, however, explain that the rigid education systems of our accelerated world are not able to respond flexibly to the needs of those involved in education. As the services available in the field of shadow education are not accessible to all due to different socioeconomic backgrounds, Mihály (2004) concludes that shadow education further increases the chances of differences between students from different social background.

According to Stevenson and Baker (1992), shadow education is a nonformal, private education that facilitates the advancement and success of students in the educational system through the effect of coaching, compensating and/or talent gains. They attribute the most prominent development role in talent management to this type of education. Participation in private lessons is usually the result of parental decisions, as every parent tries to choose the best activities for his or her child (Pásku \& Münnich, 2000). Private lessons are additional enriching activities for the development of successful students.

Bray (2010) emphasizes the role of extracurricular activities as a remedy, corrective and repetitive of school learning. However, in underfunded 
educational institutions facing financial difficulties, many extracurricular activities have become optional. In many cases it can be observed that these activities have disappeared completely from school life and can be found in the field of shadow education (Pusztai, 2015).

Worldwide, most of the commercially available out-of-school education and training services, also referred to as 'second schools', operate in the 'forprofit' sector as a private enterprise, but many nonprofit organizations run similar programs (Pásku \& Münnich, 2000). While in the past there was one-on-one training or preparation for exams and competitions, this sector has now reached enormous proportions. Nowadays, during the holidays, programs for similar topics are organized for larger groups. Programs in mathematics, mother tongue and foreign languages have the highest proportion (Bray, 1999).

The main feature of shadow education is that it is complementary to mass education and is intended to increase the student's performance, but has not (yet) created a comprehensive education system. These effects can increase the gap between those with weak and better socio - economic status, even during school breaks, leading to an increase in performance differences (Gordon Gy ri, 2008).

In Romania, there are institutions within the education system that make access to extraschool activities available to everyone free of charge. These institutions, under the name of Children's Palace/ clubs, offer a number of nonformal activities with qualified instructors that would be less feasible within the school walls. The institutions have legal personality and specialize in extracurricular activities that allow them to deepen and enrich children's knowledge. The operation of these institutions is regulated by the 2011 Education Law and the Ministry of Education Decree 4624/2015. Children's palaces and clubs are state educational units, with legal personality, specialized in extracurricular activities, within which specific instructiveeducational actions are carried out, through which knowledge is deepened and diversified, formed, where competencies are developed and practiced according to the children's vocation and option and that capitalize the children's free time by involving them in educational projects. The Education Law considers that non-formal learning is integrated and has learning 
objectives but does not explicitly follow a curriculum and may vary in duration. The activities take place in different organizational frameworks: there may be special clubs, but workshops, laboratories, gyms, sports fields, and camps can also host the programs.

In the field of shadow education, there is even a plethora of programs initiated by associations, museums, foundations, and libraries. In many cases, student participation in extraschool and extracurricular activities appears to be an effective investment in both social and cultural capital (Bourdieu, 1999; Pusztai, 2009).

\section{Methodology}

\subsection{Research questions, hypothesis}

In our research, we are examining the correlation between participation in extracurricular and extraschool activities and the results of competency measurements in national assessment.

Our hypothesis: It is supposed that there is a correlation between the participation in development activities, talent development activities, and other school-based leisure activities and the competency performance (Báthory, 1997; Darvas \& Kende, 2010, Imre et al., 2015; Pusztai, 2015). We also supposed that there is a correlation between the students' participation in extraschool activities (private classes, out-of-school camps, extraschool activities) and high-performance of the national competence measurements (Bray, 1999; Gordon Gy ri, 2008; Imre et al., 2015; Pásku \& Münnich, 2000; Pusztai, 2015).

\subsection{Research methodology}

Our research sample consisted of students from the Hungarian 4th graders in Covasna County $(\mathrm{N}=1054)$. No background questionnaires are collected during the Romanian national competence measurements. Introducing a background questionnaire as part of the Grade 4 assessment will help to 
better understand the impact of contextual factors on student learning.

In order to explore the factors influencing the results of the competence measurements, we used a self-prepared background questionnaire. The questionnaire contains 19 questions about the student's school life, study situation, extracurricular and extraschool activities, reading habits, parents' education. The results of the competence measurement (the codes) were also filled in the table attached to the questionnaire. The survey was carried out in May 2017 during national measurements. We created our database from the results of the questionnaire and competency measurements. Based on our database (KOV-ET-OM-2017 Database), we analyze the relationship between participation in extracurricular, extraschool, after-lesson activities and the school performance. School performance is interpreted in terms of the results of national assessments. Our research is based on comprehensive data collection, so we cannot speak of a representative sample, but it does provide very useful information for drawing many lessons and shaping the educational strategy.

\section{Results of the research}

The national assessments are only coded, score values are assigned to the codes to allow statistical analysis of the results. Based on the scores, we divided students into three categories: low, medium and high performing.

Based on the results, $29.5 \%$ of the students were classified as high-performing from Hungarian competency test results (their mother tongue), 25.9\% from Romanian competency test results and $24.1 \%$ from mathematics test results. In the case of medium performance, $46.2 \%$ were classified from mathematics, $40.2 \%$ from Romanian, and 35\% from Hungarian. On the other hand, almost one third of the sample can be classified into the lowperforming category: $35.5 \%$ from Hungarian, 33.9\% from Romanian and $29.7 \%$ from mathematics fall into low performance categories. 
Table no. 1. Results of competency measurements

\begin{tabular}{lccc}
\hline & Hungarian & Romanian & Maths \\
\hline Low performance & $35.5 \%$ & $33.9 \%$ & $29.7 \%$ \\
\hline Medium performance & $35.0 \%$ & $40.2 \%$ & $46.2 \%$ \\
\hline High performance & $29.5 \%$ & $25.9 \%$ & $24.1 \%$ \\
\hline
\end{tabular}

Source: KOV-ET-OM-2017 database

3.1. Relationships between extracurricular school activities and school performance

First, we mapped the effects of extracurricular activities within the school. We wanted to find out whether there is a correlation between the participation in development activities, talent development activities, and other schoolbased leisure activities and the competency measurement results. The analysis revealed that the majority of students do not participate in extracurricular activities. There is a low participation rate in talent development activities, with $20.2 \%$ attending these activities. $70.3 \%$ of the students do not participate in leisure activities organized by the school. However, the lowest rate is participation in coaching/development activities, with only $14.2 \%$ of the sample being involved in such activities.

Table no. 2. Percentage of participation in extracurricular activities

\begin{tabular}{lccc}
\hline & $\begin{array}{c}\text { Free time } \\
\text { activities }\end{array}$ & $\begin{array}{c}\text { Talent developing } \\
\text { activities }\end{array}$ & $\begin{array}{c}\text { Coaching, developing } \\
\text { activities }\end{array}$ \\
\hline Take part & $29.7 \%$ & $20.2 \%$ & $14.2 \%$ \\
\hline Do not take part & $70.3 \%$ & $79.8 \%$ & $85.8 \%$ \\
\hline
\end{tabular}

Source: KOV-ET-OM-2017 database

No significant correlation was found between the results of the national assessments and the coaching/development and leisure activities organized within the school in any of the competencies.

However, when looking at the relationship between the school afternoon program and effectiveness, we find that only $18.6 \%$ of our sample require school after school activities. No significant correlation was found between the results of 
competency measurements and the participation in coaching/development and leisure activities organized within the school in any of the competencies.

This can be explained by the fact that many institutions in the county have not yet implemented the 'School after School' program. In many cases, it is not feasible due to funding problems, while in other situations, it is not undertaken by teachers, complaining about the fact that they are overloaded with work. According to our research results, of the pupils attending the after school programe only $25.4 \%$ are successful at Hungarian competency test, $23.7 \%$ at Romanians competency test and $22.9 \%$ at mathematics competency test. Of the children who take part in after school activities, $40.5 \%$ fall into low category at Hungarian, $40.3 \%$ at Romanian and $35.1 \%$ at mathematics in competency test results.

Table no. 3. The relationship between after-school activities and the results of the national assessments

\begin{tabular}{lccccccccc}
\hline & \multicolumn{3}{c}{ Hungarian } & \multicolumn{3}{c}{ Romanian } & \multicolumn{3}{c}{ Maths } \\
\hline & low & medium & high & low & medium & high & low & medium & high \\
\hline $\begin{array}{l}\text { Parents, } \\
\text { grandparents }\end{array}$ & $31.8 \%$ & $\underline{38.0 \%}$ & $30.3 \%$ & $31.2 \%$ & $42.6 \%$ & $26.2 \%$ & $26.0 \%$ & $48.9 \%$ & $25.1 \%$ \\
\hline After school & $40.5 \%$ & $34.1 \%$ & $25.4 \%$ & $\underline{40.3 \%}$ & $36.0 \%$ & $23.7 \%$ & $35.1 \%$ & $42.0 \%$ & $22.9 \%$ \\
\hline $\begin{array}{l}\text { Individual } \\
\text { study }\end{array}$ & $37.3 \%$ & $29.8 \%$ & $32.9 \%$ & $33.2 \%$ & $38.3 \%$ & $28.5 \%$ & $30.7 \%$ & $44.4 \%$ & $24.9 \%$ \\
\hline
\end{tabular}

NHungarian: 989, $P=0,006$, adj. resid $>2$ NRomanian: 1003, $P=0,048$, adj. resid $>2$ Nmaths: 1011, $P=0,007$, adj. resid $>3$

(In the table, we underlined the data of the cells that had more randomly distributed cells.

We also examined the effect of talent management activities and found a strong significant correlation $(\mathrm{p}=0.000)$ between the results of participation in talent management activities and the result of each of the three competence areas. Of those who take part in the school-organized talent-promotion activities, $41.7 \%$ at Hungarian, $39.4 \%$ at Romanian and $34.3 \%$ at mathematics fall into high performance categories, while those who do not attend the above activities $26.3 \%$ at Hungarian, at Romanian $22.5 \%$ and at Mathematics $21.7 \%$ fall into high performance categories. Even in the average successful group, those who participate in talent development are more likely to perform than those who do not. The results of the study confirm that the enrichment activity can become an effective complement to classroom instruction (Páskuné Kiss, 2014). 
Tabel no. 4. Relationships between participating in talent development and the results of the national assessments

\begin{tabular}{lccccccccccc}
\hline & \multicolumn{3}{c}{ Hungarian } & & & Romanian & & \multicolumn{2}{c}{ Maths } \\
\hline & low & medium & high & low & medium & high & low & medium & high \\
\hline Takes part & $19.4 \%$ & $38.8 \%$ & & $\underline{41.7 \%}$ & $20.7 \%$ & $39.9 \%$ & $\underline{39.4 \%}$ & $17.9 \%$ & $47.8 \%$ & $\underline{34.3 \%}$ \\
\hline $\begin{array}{l}\text { Does not } \\
\text { take part }\end{array}$ & $\underline{39.5 \%}$ & $34.2 \%$ & $26.3 \%$ & $\underline{37 \%}$ & $40.5 \%$ & $22.5 \%$ & $\underline{32.4 \%}$ & $45.9 \%$ & $21.7 \%$ \\
\hline
\end{tabular}

NHungarian: 984, NRomanian:999, Nmaths: 1006, Sig.***, Adj.resid>3

(In the table, we underlined the data of the cells that had more randomly distributed cells.)

We found a significant correlation between student performance and participation in school camps $(\mathrm{p}=0.000)$. In all three areas of competence, the benefits of attending a school camp can be demonstrated. Of the children who have taken part in school camps, 35\% at Hungarian, 29.6\% at Romanian and $29.2 \%$ at maths fall into high performance category, while $20.1 \%$ at Hungarian, $19.8 \%$ at Romanian and $16 \%$ at maths achieve high performance category from the non-participants. In terms of average performance, there is no significant difference between those who attend and do not attend school camps.

For all three areas of national assessment, we find that those who do not participate in the above mentioned and analysed activities are more likely to fall into the low performance category. In the context of increasing academic performance and extracurricular activities, it can be stated that "especially for students away from school culture, integration into the school normative system must first be promoted through inter- and intrageneration building relationships and building trust" (Pusztai, 2015, p. 36). A very good opportunity is provided by such activities.

Most interesting is the correlation between school-organized camps and the mother tongue competence measurements results. Here, too, it is noticeable that the average performance is less different between participants and non-participants. $35 \%$ of those who participate in camps achieve high results, while those who do not participate make up $20.1 \%$ of this category. There is also a striking difference between participants and non-participants: $45.7 \%$ of those who do not participate are among the low achievers, and only $29.6 \%$ of those who participate fall into this category. 
Table no. 5. Relationships between Hungarian/mother tongue performance and participation in school-organized camps

\begin{tabular}{llcccc}
\hline & & \multicolumn{3}{c}{ Hungarian/Mother tongue performance } \\
\hline \multirow{2}{*}{ Takes part } & $\%$ & Low performance & Medium performance & High performance \\
& Adj.resid & $29.6 \%$ & $35.4 \%$ & $35 \%$ \\
\hline \multirow{2}{*}{$\begin{array}{l}\text { Does not } \\
\text { take part }\end{array}$} & $\%$ & -5.0 & .4 & 4.8 \\
\hline
\end{tabular}

$N=942$, Sig. $* * *$

3.1. The relationships between shadow education/extraschool activities and school performance

The effect of camps organized outside the school on performance is similar to that of school camps ( $\mathrm{p}=0.000)$. From the participants, $35.7 \%$ at Hungarian, $31.2 \%$ at Romanian and $34.4 \%$ at maths achieved high performance. We can also state that $42.9 \%$ of non-participants at Hungarian, $38.8 \%$ at Romanian and $34.9 \%$ at mathematics are in the low performance group. With respect to average performance, it can be noted that, with the exception of mathematics, students enrolled in out-of-school camps have a higher proportion in the middle category than those who do not attend out-of-school camps).

Table no. 6. Relationships between participation in camps outside the school and the results of the national assessments

\begin{tabular}{lccccccccc}
\hline & \multicolumn{3}{c}{ Hungarian } & \multicolumn{3}{c}{ Romanian } & \multicolumn{3}{c}{ Maths } \\
\hline & low & medium & high & low & medium & high & low & medium & high \\
\hline $\begin{array}{l}\text { Takes } \\
\text { part }\end{array}$ & $26.4 \%$ & $37.9 \%$ & $\underline{35.7 \%}$ & $28.1 \%$ & $40.7 \%$ & $\underline{31.2 \%}$ & $21.7 \%$ & $43.9 \%$ & $\underline{34.4 \%}$ \\
\hline $\begin{array}{l}\text { Does } \\
\text { not take } \\
\text { part }\end{array}$ & $\underline{42.9 \%}$ & $32.3 \%$ & $24.8 \%$ & $\underline{38.8 \%}$ & $38.8 \%$ & $22.3 \%$ & $\underline{34.9 \%}$ & $48.1 \%$ & $17.0 \%$ \\
\hline
\end{tabular}

Nmaths: 946, NHungarian: 925, NRomanian: 940, Sig.***, Adj.resid>3

(In the table, we underlined data for cells that have more random distribution)

Examining the effects of private lessons, we found that our results did not show a significant correlation between mathematics lessons and competency measurement. 
Table no.7. Relationships of participation in sports, foreign language and music in private lessons and the results of the national assessments

\begin{tabular}{|c|c|c|c|c|c|c|c|c|c|c|}
\hline & \multicolumn{4}{|c|}{ Hungarian } & \multicolumn{3}{|c|}{ Romanian } & \multicolumn{3}{|c|}{ Maths } \\
\hline & & low & medium & high & low & medium & high & low & medium & high \\
\hline \multirow[t]{2}{*}{ Sports } & $\begin{array}{l}\text { Takes } \\
\text { part }\end{array}$ & $21.7 \%$ & $39.1 \%$ & $\underline{39.1 \%}$ & $19.6 \%$ & $\underline{48.8 \%}$ & $\underline{31.5 \%}$ & $14.2 \%$ & $44.6 \%$ & $\underline{41.2 \%}$ \\
\hline & $\begin{array}{l}\text { Does } \\
\text { not } \\
\text { take } \\
\text { part }\end{array}$ & $\underline{40.2 \%}$ & $33.7 \%$ & $26.1 \%$ & $\underline{38.8 \%}$ & $37.3 \%$ & $24.0 \%$ & $\underline{35.0 \%}$ & $46.7 \%$ & $18.2 \%$ \\
\hline \multirow[t]{2}{*}{ Music } & $\begin{array}{l}\text { Takes } \\
\text { part }\end{array}$ & $13.0 \%$ & $39.0 \%$ & $\underline{48.0 \%}$ & $19.0 \%$ & $43.0 \%$ & $\underline{38.0 \%}$ & $10.9 \%$ & $45.5 \%$ & $\underline{43.6 \%}$ \\
\hline & $\begin{array}{l}\text { Does } \\
\text { not } \\
\text { take } \\
\text { part }\end{array}$ & $\underline{38.0 \%}$ & $34.7 \%$ & $27.4 \%$ & $\underline{35.5 \%}$ & $39.9 \%$ & $24.6 \%$ & $\underline{31.7 \%}$ & $46.3 \%$ & $22.0 \%$ \\
\hline \multirow[t]{2}{*}{$\begin{array}{l}\text { Foreign } \\
\text { language }\end{array}$} & $\begin{array}{l}\text { Takes } \\
\text { part }\end{array}$ & $18.2 \%$ & $41.8 \%$ & $\underline{40.0 \%}$ & $20.7 \%$ & $\underline{49.5 \%}$ & $29.7 \%$ & $12.5 \%$ & $50.0 \%$ & $\underline{37.5 \%}$ \\
\hline & $\begin{array}{l}\text { Does } \\
\text { not } \\
\text { take } \\
\text { part }\end{array}$ & $\underline{37.7 \%}$ & $34.2 \%$ & $28.1 \%$ & $\underline{35.4 \%}$ & $39.1 \%$ & $25.4 \%$ & $\underline{31.8 \%}$ & $45.7 \%$ & $22.5 \%$ \\
\hline
\end{tabular}

NHungarian: 984, NRomanian: 999, Nmaths: 1006, Sig.***, Adj.resid>3. (In the chart, we underlined data for cells where more than the random distribution is located)

A strong significant correlation $(\mathrm{p}=0.000)$ was found between foreign language, music and sports activities out of school and performance. The sports, art, academic activities outside the classroom have a positive effect on performance (Pusztai, 2015). About $41.2 \%$ of the participants registered in sports activities fall into the high performance zone and only $14.2 \%$ into the low performance category. While only $18.2 \%$ of those who do not participate can be classified as high achievers. There is a slight difference in average performance between those who attend (44.6\%) and those who do not attend sports $(46.7 \%)$. There is a strong correlation between attending music and competence measurements results. Those who do not attend private music classes are more likely to fall into the low category in all three measurement areas. The impact of a foreign language is also very pronounced: $40 \%$ of those who take private lessons in a foreign language are included in the high performance category for native speakers. In the Romanian language area, 29.7\% are classified as high-performing. Analyzing the impact of sports, foreign language and music private lessons, we can conclude that the benefits of participating in these activities are evident in all three areas of competence. The sports, music and foreign language extracurricular activities seem to be effective extracurricular investments, as their positive effect is confirmed in mathematical and linguistic outcomes (Pusztai, 2015). Our results are in unison with the outcomes of other similar 
researches which show that supplementary private education may apply to educational content/areas such as mathematics that every student must master at a certain level, but can also target other areas such as music education, art education, and various sports (Gordon Gy ri, 2008).

Positive effects of out-of-school clubs are also evident in the study. Significant correlation can be found between out-of-school visits and competency assessment results. Those who participate in such activities are much more likely to be classified in the high performance group than those who do not attend extracurricular activities.

Table no. 8. Relationships between extracurricular activities and the results of the national assessments

\begin{tabular}{lccccccccc}
\hline & \multicolumn{3}{c}{ Hungarian } & \multicolumn{3}{c}{ Romanian } & \multicolumn{3}{c}{ Maths } \\
\hline & low & medium & high & low & medium & high & low & medium & high \\
\hline $\begin{array}{l}\text { Takes } \\
\text { part }\end{array}$ & $22.1 \%$ & $34.8 \%$ & $\underline{43.1 \%}$ & $25.3 \%$ & $39.7 \%$ & $\underline{35.0 \%}$ & $15.4 \%$ & $47.1 \%$ & $\underline{37.5 \%}$ \\
$\begin{array}{l}\text { Does not } \\
\text { take part }\end{array}$ & $\underline{42.3 \%}$ & $35.3 \%$ & $22.4 \%$ & $\underline{38.2 \%}$ & $40.5 \%$ & $21.4 \%$ & $\underline{36.8 \%}$ & $45.9 \%$ & $17.3 \%$ \\
\hline
\end{tabular}

NHungarian: 984, NRomanian: 999, Nmaths: 1006, Sig.***, Adj.resid>3.

(In the table, we underlined the data of the cells that had more randomly distributed cells)

The highest rate can be observed in the field of Hungarian competency measurement results: $43.1 \%$ of the participants in the professional groups are in the high performance group, compared to $35 \%$ in Romanian and $37.5 \%$ in mathematics. Regarding low efficiency, $42.3 \%$ at Hungarian, $38.2 \%$ at Romanian, and $36.8 \%$ at maths have poor results. There is no significant difference in medium scores between those who attend and those who do not attend extracurricular activities. Strong significance $(\mathrm{p}=0.000)$ can be detected if parents' educational level and participation in extracurricular activities and camps are examined. Similarly, there is a strong correlation $(p=0.000)$ between participation in activities in these areas of shadow education and the labor market situation of parents. The children of parents with higher education and regular employment are more involved in these activities.

\section{Discussion}

In our analysis, we focused on the effects of extracurricular activities organized by the school and extraschool activities/shadow education. Our 
results show that there is no significant correlation in terms of performance and the participation in extracurricular activities, except of talent management activities and school camps. We found a weak significant relationship between afternoon school activity and effectiveness. A school-after-school program would be important in overcoming disadvantages and increasing equal opportunities if content and quality are appropriate. However, pushing time frames alone will not lead to increased efficiency. The proportion of participants in the coaching/development and leisure activities is very low, but the results of the national competency assessment show that there is a great need for such programs and activities. If out-of-class activities are being incorporated into an all-day school program, the benefits of these activities could be manifested within appropriate organizational frameworks, implemented with quality content. If we look at the mother tongue results, in line with Pletl's (2012) research, we find that the proportion of highperforming individuals decreases and the average layer's performance slips below the $50 \%$ performance range. This draws attention to the fact that students with low levels of reading literacy in primary education are no longer able to catch up. Therefore, greater involvement of students in appropriate corrective, development and/or compensatory activities is essential.

The benefits of extraschool activities, music, foreign language and sports, private lessons/activities, and the various camps are clearly demonstrated in all three areas of competences. Our research results show a significant correlation between performance and attendance of extraschool activities. The beneficial effects of activities in different areas of shadow education are evident, but in many cases parents have to pay, which is almost impossible for disadvantaged families. In addition to the beneficial effects of shadow education, it should also be mentioned that it greatly enhances educational inequalities.

The right content and quality are essential for successful development activities and preparation for school afternoons. In order to compensate for the disadvantages, schools should pay particular attention to integrating students into the school standard system, offering a wealth of communitybuilding extracurricular activities and successfully implementing the afterschool program. By spending time on preparing for the day ahead, together with well-organized, quality leisure content and personality development activities, in the gap between those with different socio-economic status 
can be reduced and school performance increased.

\section{NOTES}

1 MEN and WB (2015), Strategy on reducing early school leaving, Bucharest, available at http://www.edu.ro/sites/default/files/_fi\%C8\%99iere/InvatamantPreuniversitar/2015/Strategie-PTS /Strategia-PTS-2015.pdf.

2 ORDER for the modification and completion of the Methodology for organizing the 'School after school' Program, approved by Order of the Minister of Education, Research, Youth and Sports no. 5349/2011 in accordance with Government Decision no. 26/2017.

\section{References}

- Bacskai, K. (2015). Iskolák a társadalom peremén. Belvedere Meridionale Kft.

- Báthory, Z. (1997). Tanulók, iskolák, különbségek. Okker Kiadó.

- Bray, M. (1999). The Shadow Education System: Private Tutoring and its Implications or Planners. Fundamentals of Educational Planning No. 61. UNESCO International Institute for Educational Planning.

- Bray, M. (2010). Researching Shadow Education: methodological challenges and directions. Asia Pacific Education Review, 11, 3-13. https://doi.org/10.1007/s12564-009-9056-6

- Bourdieu, P. (1999). Gazdasági tõke, kulturális tõke, társadalmi tõke. In R. Angelusz (Ed.), A társadalmi rétegzõdés komponensei (pp. 156-178). Új Mandátum Kiadó.

- Buda, A. (2011). Értékelési filozófiák és pedagógiai mérés. Debreceni Egyetem Tudományegyetemi Karok.

- Darvas, Á., \& Kende, Á. (2009). Az egész napos iskola nemzetközi tapasztalatai, hazai lehetõségei. Esély.

http://www.esely.org/kiadvanyok/2010_3/02darvaskende.indd.pdf

- Fehérvári, A. (2015). A hátrányos helyzetû tanulók oktatásának változása 20062014. In A. Fehérvári \& G. Tomasz (Eds.), Kudarcok és megoldások. Iskolai hátrányok, lemorzsolódás, problémakezelés (pp. 32-52). Oktatáskutató és Fejlesztõ Intézet.

- Fóris-Ferenczi, R. (2008). A tervezéstõl az értékelésig. Tanterv-és értékeléselmélet. Ábel Kiadó, Kolozsvár.

- Fûz, N. (2017). Iskolán kívüli színterek az általános iskolai oktatásban. Magyar Pedagógia, 117(2), 197-220.

- Fûz, N. (2018). Az iskolán kívüli tanórák hatékonyságának megítélése általános iskolás diákok és pedagógusok körében. Iskolakultúra, 28(8-9), 38-53. 
- Gordon Gyõri, J. (1998). Mitõl hatékony még a japán oktatás? Magyar Pedagógia, 4(98), 273-317.

- Gordon Gyõri, J. (2008). Tömegoktatás és kiegészítõ magánoktatás-ipar. Educatio, 2, 263-274.

- Imre, A. (2016). Lehetõségek és akadályok a tanórán kívüli tanulásban: délutáni foglalkozások és pedagógusi munkaterhek. In M. Szemerszki (Ed.), Hátrányos helyzet és iskolai eredményesség (pp. 75-100). Oktatáskutató és Fejlesztõ Intézet.

- Imre, A. (2015). Eredményesség és társadalmi beágyazottság. Oktatáskutató és Fejlesztõ Intézet.

- Imre, A. et al. (2015). Az iskolai tanulás (idõ) kereteink és határainak kérdései nemzetközi tapasztalatok tükrében. In A. Imre (Ed.), Eredményesség és társadalmi beágyazottság (pp. 37-50). Oktatáskutató és Fejlesztõ Intézet.

- MEN \& BM. (2015). Strategia privind reducerea părăsirii timpurii a şcolii. http://www.edu.ro/sites/default/files/_fi\%C8\%99iere/Invatamant-Preuniversitar/ 2015/Strategie-PTS/Strategia-PTS-2015.pdf

- Mihály, I. (2004). Tanulás „árnyékban”, avagy a tanügyi második gazdaság mûködése. Új Pedagógiai Szemle.

- Páskuné Kiss, J. (2014). Tanórán kívüli iskolai és iskolán kívüli programok a tehetséggondozásban. Magyar Tehetségsegítõ Szervezetek Szövetsége.

- Pásku, J., \& Münnich, Á. (2000). Az extrakurrikuláris oktatás nem specifikus hatásai. Magyar Pedagógia, 100(1), 59-77.

- Péter, L. (2012). Reform és visszhangok. A közoktatási reform fogadtatása romániai magyar pedagógusok körében. Kolozsvári Egyetemi Kiadó, Kolozsvár.

- Pletl, R. (2012). Helyzetjelentés az erdélyi magyar diákok olvasási és szövegértési képességének színvonaláról. Ábel Kiadó, Kolozsvár.

- Pusztai, G. (2009). A társadalmi tõke és az iskola. Kapcsolati erõforrások hatása az iskolai pályafutásra. Új Mandátum Könyvkiadó.

- Pusztai, G. (2015). Az eredményesség kapcsolati beágyazottsági háttere. In A. Imre (Ed.), Eredményesség és társadalmi beágyazottság (pp. 23-36). Oktatáskutató és Fejlesztõ Intézet.

- Szántó, B. (2015). A IV. osztályos tanulók anyanyelvi szövegértésének szintje a 2013/2014-es országos felmérések tükrében. PedActa, 5(1), 1-10.

http://padi.psiedu.ubbcluj.ro/pedacta/article_5_1_1.pdf

- Stevenson, D. L., \& Baker, D. P. (1992). Shadow education and allocation in formal schooling: Transition to university in Japan. American Journal of Sociology, 97(6), 1639-1657.

- Széll, K. (2015). Szegregáció és hátránykompenzáció - Pedagógusattitûdök. In A. Fehérvári \& G. Tomasz (Eds.), Kudarcok és megoldások. Iskolai hátrányok, lemorzsolódás, problémakezelés (pp. 53-72). Oktatáskutató és Fejlesztõ Intézet.

- Singer, F. M. (2013). Romanian Research in Education: Where to?. Revista de Politica Ştiin ei şi Scientometrie, 2(4), 286-302. 
The online version of this article can be found at: http://revped.ise.ro/category/2020-en/

\section{$( \mathrm { Cc } ) \longdiv { \mathrm { B } - \mathrm { Ne } - \mathrm { BA } }$}

This work is licensed under the Creative Commons Attribution-NonCommercial-ShareAlike 4.0 International License.

To view a copy of this license, visit http://creativecommons.org/licenses/by-nc-sa/4.0/ or send a letter to Creative Commons, PO Box 1866, Mountain View, CA 94042, USA.
Versiunea online a acestui articol poate fi găsită la: http://revped.ise.ro/category/2020-ro/

\section{(oc) EY-NC-SA}

Această lucrare este licen iată sub Creative Commons Attribution-NonCommercial-ShareAlike 4.0 International License.

Pentru a vedea o copie a acestei licen e, vizita $i$ http://creativecommons.org/licenses/by-nc-sa/4.0/ sau trimite i o scrisoare către Creative Commons, PO Box 1866, Mountain View, CA 94042, SUA. 


\title{
ACADEMIC SKILLS SELF-EFFICACY AND COLLEGE-GOING OUTCOME EXPECTATIONS AS PREDICTORS OF UNDERGRADUATES' SATISFACTION WITH THEIR CHOSEN AREA OF STUDY AND DROPOUT INTENTIONS
}

\author{
Raluca Livin i* \\ Dragoş Iliescu**
}

University of Bucharest,

Faculty of Psychology and Educational Sciences, Bucharest, Romania

raluca_livinti@yahoo.com,dragos.iliescu@fpse.unibuc.ro

\begin{abstract}
Building on the integrative model from the Social Cognitive Career Theory, the present study investigates in a longitudinal approach the association between students' academic skills self-efficacy, college-going outcome expectations, and intention to drop out of their academic studies, as mediated by satisfaction with their chosen area of study. It also investigates whether vocational fit/congruence adds an increment to the aforementioned variables in explaining the intention to drop out of university. The sample included 167 freshmen students in various areas of study who filled in questionnaires of self-efficacy, outcome expectations, and vocational fit in the first weeks at university. In the second semester, six months later, they filled in instruments that measure satisfaction with the chosen area of study and dropout intentions. The results showed that the best fit was that of a model in which satisfaction with the area of study is a full mediator of the relationship between self-efficacy and dropout intentions and between outcome expectations and dropout intentions. The Iachan and Zener-Schnuelle fit indices alone were a predictor of dropout intentions. However, its addition to the model does not bring an explanatory increment but rather leads to a poorer fit of the model. Implications are discussed.
\end{abstract}

* PhD Candidate, University of Bucharest, Faculty of Psychology and Educational Sciences, Bucharest, Romania.

** Professor, PhD, University of Bucharest, Faculty of Psychology and Educational Sciences, Bucharest, Romania. 
Keywords: academic skills self-efficacy, college-going outcome expectations, Holland congruence index, Social Cognitive Career Theory, university dropout.

\section{Rezumat}

Având drept cadru teoretic modelul integrativ din Teoria social-cognitivă a carierei, studiul de fa ă investighează într-o abordare longitudinală rela ia dintre autoeficacitatea cu privire la deprinderile academice, aşteptările pozitive legate de calitatea de absolvent al unei facultă $i$ şi inten ia de a renun a la facultate, având ca mediator satisfac ia cu profilul ales. Studiul investighează, de asemenea, dacă potrivirea/congruen a voca ională aduce un increment peste variabilele men ionate anterior în explicarea inten iei de a renun a la facultate. Eşantionul a fost format din 167 de studen i înscrişi în primul an în domenii diverse, care au completat instrumente de măsurare a autoeficien ei, a aşteptărilor și a potrivirii/ congruen ei voca ionale în primele săptămâni ale anului universitar. În al doilea semestru, şase luni mai târziu, au completat instrumente de măsurare a satisfac iei fa $\breve{a}$ de profilul ales şi a inten iei de a renun a la facultate. Rezultatele au arătat că cea mai bună potrivire o are un model în care satisfac ia fa ă de profilul ales este un mediator total în rela ia dintre autoeficien ă şi inten ia de a renun a la facultate şi în rela ia dintre aşteptări şi inten ia de a renun a la facultate. Indicii de potrivire Iachan şi Zener-Schnuelle au prezis inten ia de a renun a la facultate. $\mathrm{Cu}$ toate acestea, adăugarea lor la model nu aduce un increment explicativ, ci din contra, conduce la o potrivire mai mică a modelului. Sunt discutate implica iile.

Cuvinte cheie: abandon universitar, autoeficien $\breve{a}$ cu privire la deprinderi academice, aşteptări pozitive legate de calitatea de absolvent al unei facultă $i$, indicele de congruen ă Holland, Teoria social cognitivă a carierei.

\section{Introduction}

University dropout is an important topic in educational research, due to its economically, socially, and psychologically important implications. The social and economic importance of completing tertiary education has been acknowledged in the Europe 2020 strategy of the European Commission (European Commission, 2010), which proposed as target the growth of the population aged 30-34 that finished tertiary education from $31 \%$ to at least $40 \%$ by 2020 . For 2018 , the European average was $40.7 \%$, while the average in Romania was much lower, at $24.6 \%$ (European Commission, 2019). The same study showed the impact of tertiary level education on the employment rate. For Romania, the employment rate for an ISCED 5-8 educational level 
is $88.9 \%$, while for an ISCED 3-4 educational level the employment rate is much lower, at $67.7 \%$ (European Commission, 2019). Dropout has a significant economic effect, in the US people with college degrees earning an average hourly wage that is $65 \%$ higher than college dropouts (Gould, 2019). A synthesis of the statistical analyses conducted on the Romanian population regarding the beneficial effect of education on both occupation rate and salary can be found in Varly, Iosifescu, Fartuşnic, Andrei and Her eliu (2015). Also, dropout has important psychological effects on self-esteem (Hoeschler \& Backes-Gellner, 2017). We did not identify studies reporting on the psychological effects of dropout in Romania.

The statistical results regarding educational dropout in Romania inform the interest for this line of research, in order to limit its expansion and effects. For example, Eurostat shows that Romania was in 2018 in the third place in the European Union regarding early leavers from education and training between 18 and 24 years old, with 15.1\% (Eurostat, 2020). Although lower than in the previous years (for example, $18.5 \%$ for Romania in 2016), this level is still much higher than the average of the European Union (10.2\% in 2019).

Although the Romanian universities compute statistics regarding student dropout, those are seldom available publicly. Rare published examples are statistics presented in ANOSR (2014) and Stăiculescu and Richi eanuNăstase (2018). ANOSR (2014) reported that university dropout was as high as $40 \%$ for the graduating year 2012-2013, based on data from 20 state universities, bachelor degree studies. The results suggest that out of those $40 \%$ dropouts, $48 \%$ of students drop out in the freshman year, and $40 \%$ in the senior year. Stăiculescu and Richi eanu-Năstase (2018) reported statistics for the freshman year at the Bucharest University of Economic Studies (ASE), the biggest university with an economics profile in Romania, with more than 20000 students. For the academic years between 2013 and 2017, the lowest dropout rate was in the 2015-2016 academic year (14.32\%), while the highest was in the 2013-2014 academic year (16.28\%).

The psychological mechanisms of the dropout process have been under scrutiny especially due to the rise of the studies conducted in the Social Cognitive Career Theory (SCCT; Lent, Brown \& Hackett, 1994) framework. 
The present study contributes to the literature by reporting on research focused on academic dropout, conducted through the lens of SCCT and Holland's vocational interest theory.

\subsection{University dropout}

Dropout is defined in many alternative ways (Lee \& Choi, 2011; RodríguezGómez et al., 2015). In its most common meaning, university dropout focuses on students leaving university studies before earning a degree (Heublein, 2014); this is the definition that is habitually used in most studies. It has, however, a number of limitations, most notably an inherent difficulty in distinguishing between dropout and different forms of mobility (Heublein, 2014). For example, students may choose to transfer to another local or international university, give up their current enlistment in order to pursue a different area of study, finish university without the final exam, dissertation or thesis defense, or leave temporarily and come back later to graduate. In Romania, there is also a separate category of students who were declared accepted in the summer admission session, but whom, for various reasons (usually, because they have been admitted to several universities), do not confirm and sign the study contract in October and are officially declared dropouts by withdrawal. Other categories of officially reported dropouts are students who got expelled because they did not get the credits necessary to pass the undergraduate academic year or because they did not pay their fees - some of whom, to complicate matters even more, do not attend their exams and do not pay their fees as an implicit form of giving up on their studies.

The two models that were traditionally used in university dropout research are the Student Integration Model (Tinto, 1975) and Bean and Metzner's model of student dropout (1985).

Tinto's model states that student dropout is caused by a lack of congruency between themselves and the academic institution. Student motivation, academic achievement, and intellectual ability, along with social interaction with peers and the institution are postulated in this model to lead to goal and institutional commitment. Dropout occurs when goal commitment is present, 
but institutional commitment is absent. According to Bean and Metzner's model, several categories of factors, such as academic variables (the student's approach to study), academic outcomes (GPA), and environmental variables (such as finances and family context) lead to psychological outcomes (utility, satisfaction, goal commitment, and stress), to attitudes (that then lead to intention to leave) and finally to dropout behavior. The two models have their merits, especially by emphasizing the joint role of social and environmental factors and of academic factors in shaping dropout/persistence decisions. They also show a major limitation, in that that they both fail to consider intrinsic factors as predictors of college dropout (Cabrera et al., 1993).

Some individual factors have long been demonstrated to be positively related to the intention to withdraw from the university. Among them, there are factors such as gender (with male students being more prone to dropping out than female students), high school GPA, SAT scores, academic-related skills, and other numerous predictors (see Robbins et al., 2004). Studies also show that a key period for dropout is the second semester of study (GrauValldosera \& Minguillón, 2014).

\subsection{The SCCT and persistence intentions}

The SCCT is a vocational psychology theory that has been intensely researched in the past 25 years. It consists of several models that explain interest formation, career decision making, and performance (interest, choice action, performance, work and academic satisfaction models, and career management model) (Lent et al., 1994; Lent \& Brown, 2006; Lent \& Brown, 2013). The SCCT focuses on key concepts such as self-efficacy (domainspecific confidence about successfully engaging in an activity/task), outcome expectations (positive expectations from engaging in an activity), interest in specific activities, goals, and choice actions (e.g., pursuing a certain career, dropping out of college, etc.).

Social-cognitive factors play a central role in studies conducted in recent years and they prove to be good predictors for university persistence. Lent et al. (2013) suggested a combination of some of the paths in the other 
SCCT models and worked towards an integrative model, with academic persistence as a final outcome. Satisfaction with the pursued area of study, although initially not a part of the various SCCT models, began thus to be studied in relation with other SCCT variables, such as self-efficacy, outcome expectations, academic satisfaction, environmental supports and barriers, formed interests, personality features, and affective disposition.

A number of studies explored and supported the paths of this model. Selfefficacy has been found to be a predictor of academic satisfaction (Flores et al., 2014; Morris \& Lent, 2019; Mujica et al., 2019), as well as of academic persistence intentions, in cross-sectional designs (Garriott et al., 2017; Mujica et al., 2019) in longitudinal designs (Lent et al., 2015; Navarro et al., 2014), and in meta-analyses (Robbins et al., 2004), and it has also turned out to be a predictor of actual persistence four undergraduate semesters later (Lent et al., 2016). Academic satisfaction turned out to be an antecedent of intentions to persist (Lent et al., 2015; Lent et al., 2016; Morris \& Lent, 2019; Navarro et al., 2014). Satisfaction with major emerged as a mediator in the relation between the social-cognitive factors and intention to persist in the chosen major (Lent et al., 2016). Outcome expectations emerged as an antecedent of academic satisfaction and persistence in some of these studies, but not in all of them (Truong \& Miller, 2018).

However, all these studies conducted in the SCCT framework focused on persistence. To our knowledge, there are no studies focusing on actual dropout. At first sight, the two are conceptually opposed, persistence focusing on remaining enrolled in a chosen major until graduation - hence, not dropping out. Depending on the educational system and area of study, the focus can be on one of the two concepts. Studying persistence makes more sense for the US academic system, where not persisting may imply changing majors, but most of the time remaining with the same university or department. In Romania, where the educational system does not imply majors and minors, not persisting in one area of study is equivalent to dropping out, and therefore has more implications: students lose all of their credits, they lose their government-subsidized spots (if they had one); pursuing another area of study implies another entrance process/exam at another department or university, generating significant costs in terms of time and money for those students who decide to follow this route. Previous studies rarely involved 
other majors/areas of study than Engineering and while diverse ethnic samples have been studied (Hispanic, African American, and Asian American) (Flores et al., 2014; Navarro et al., 2014; Truong \& Miller, 2018), few studies were conducted outside of the US (Mujica et al., 2019). Additional studies should be conducted in other cultures and countries, and our study aims at filling this gap in research by using a Romanian sample, with conclusions that could both add validation data to the SCCT models and have practical implications for the Romanian practices in preventing university dropout.

Building on previous research that shows that the paths of the integrative model work for the prediction of persistence in other cultures and area of study, we expect that the longitudinal data collected in Romania will support the hypotheses below:

H1. Academic self-efficacy is a predictor of (and is negatively related

to) the dropout intentions, and this effect is mediated by satisfaction with the chosen area of study.

H2. Academic outcome expectations are a predictor of (and are negatively related to) the dropout intentions, and this effect is mediated by satisfaction with the chosen area of study.

\subsection{Holland's theory and vocational fit/congruence}

Holland's theory is an exponent of the larger realm of person-environment fit theories and postulates that there are 6 types of vocational interests/ personality traits that may be characteristic both for individuals and environments; these 6 form a hexagonal structure (the RIASEC hexagon): realistic $(\mathrm{R})$, investigative (I), artistic (A), social (S), enterprising (E), and conventional (C) (Holland et al., 1994). This career theory suggests that vocational congruence (fit) occurs when there is a match between one's interests and those required by different environments (e.g., work, study). When there is a match, the individual will be more satisfied and more inclined to persist in a job, educational environment, or field of study. Several types of vocational congruence indices were proposed to this effect and can be readily computed: hexagonal, Iachan, and Zener-Schnuelle (Holland et al., 1994). 
While in work environments vocational fit has been shown to be a predictor of important outcomes (Iliescu et al., 2015), the literature is split regarding the utility of vocational fit in academic contexts. Some results show that vocational congruence is associated with satisfaction and persistence in academic contexts (Nye et al., 2012; Tracey \& Robbins, 2006; Tsabari et al., 2005), while others show that it is not (Fu et al., 2019). To our knowledge, no published study investigated the utility of using SCCT and vocational congruence together. Given the split opinion about the utility of the congruence indices and the fact that the SCCT seems to explain well the persistence intention, we will investigate the following research question:

Research question: Do vocational fit indices bring an increment over social cognitive variables in explaining the intention to drop out of university?

\section{Method}

\subsection{Participants and procedure}

The sample consisted of 167 university students enlisted in a variety of programs, with ages between 17 and $32(\mathrm{M}=19.09, \mathrm{SD}=1.73)$, among them 26 males $(15.60 \%)$. The inclusion criterion was that the participants were first-year first-time university students.

The participants filled in instruments that measure self-efficacy and outcome expectations in the first weeks of enrollment in the university. Six months later, they filled out a measure of satisfaction with the chosen area of study and assessed their dropout intentions.

The instructions emphasized that the study investigated the opinion of firstyear first-time university students about university life and psychological factors in decision making and that they should answer with their own opinions at the moment of testing, in relation to the area of study they were enrolled in.

\subsection{Measures}

Academic skills self-efficacy. Self-efficacy was measured with the revised form of the Academic Behavioral Confidence (the ABC scale; Sander \& 
Sanders, 2009). In this scale, respondents assess how confident they feel about performing a series of 17 academic activities, for example: "Give a presentation to a small group of fellow students". Answers are coded on a range from 1 (not at all confident) to 5 (very confident). The Cronbach alpha coefficient for this study was .92 .

College-going outcome expectations. Outcome expectations were assessed using the Student Outcome Expectation Scale (SOES; Landry, 2003). The SOES consists of 13 items pertaining to the potential positive outcomes of attending university, with answers coded on a range from 1 (strongly disagree) to 4 (strongly agree). An example of an item is: "Getting my undergraduate degree also means I will do better with the rest of my life". The Cronbach alpha coefficient for the present study was .79.

Vocational fit (congruence). Vocational fit/congruence with the study program was measured with the 3 types of congruence indices recommended by Holland et al. (1994): Hexagonal, Iachan, and Zener-Schnuelle. The indices were computed from the participants' responses to the 66 items Activities section of the Self-Directed Search (SDS; Holland et al., 1994) and were based on two letters Holland codes. We used the official Romanian version of the SDS, with the permission of the publisher. The psychometric properties of the Romanian version of SDS are largely documented in Holland et al. (2010). The method of computation of the indices is described in detail in the technical manual for the SDS.

Satisfaction with the area of study. Satisfaction with the area of study was measured with the Academic Major Satisfaction Scale (AMSS; Nauta, 2007). This scale consists of 6 items assessing general satisfaction with the area of study on a scale ranging between 1 (strongly disagree) and 5 (strongly agree). One example of an item is "I feel good about the major I've selected". The Cronbach alpha coefficient for this study was .90. For the Romanian version, we replaced the word "major" in the items, because it does not have a correspondent in the Romanian educational system, with "profil/specializare".

Intention to drop out of the university. Dropout intentions were measured with the item "I intend to drop out this faculty", scaled between 1 (strongly disagree) and 7 (strongly agree). 
The translation and adaptation process of the ABC scale, the SOES, and the AMSS was conducted according to the guidelines for translation and adapting tests published by the International Test Commission (2017). Specifically, we employed a process of guided forward translation. Each of the authors of the present paper translated individually each item. In the process, in order to ensure the quality of the Romanian adaptation, we also used for each of the items the Item Translation and Adaptation Review Form proposed by Hambleton and Zenisky (2011). This is a 25-item checklist that assesses the translation of the items on several dimensions, such as General, Item format, Grammar and phrasing, and Culture. After the individual translation, the team reunited and analyzed the results and reached a final version of the items.

\section{Results}

Means, standard deviations, reliabilities, and correlations among variables were computed with IBM SPSS Statistics 22 (IBM Corp, 2013). The results are shown in Table no. 1. Mediation analysis was performed using both the Process macro in SPSS (Hayes, 2013) and Mplus7 (Muthén \& Muthén, 1998-2012). Full models were tested with Mplus.

Table no. 1. Means, standard deviations, reliabilities, and correlations among variables

\begin{tabular}{|c|c|c|c|c|c|c|c|c|c|c|c|}
\hline & \multirow[b]{2}{*}{ Variable } & \multirow[b]{2}{*}{$M$} & \multirow[b]{2}{*}{$S D$} & \multirow[b]{2}{*}{ Alpha } & \multicolumn{7}{|c|}{ Correlations } \\
\hline & & & & & 1 & 2 & 3 & 4 & 5 & 6 & 7 \\
\hline 1 & Self-efficacy & 92.34 & 16.50 & .92 & - & & & & & & \\
\hline 2 & Outcome expectations & 41.32 & 4.68 & .79 & $.33^{* *}$ & - & & & & & \\
\hline 3 & $\begin{array}{l}\text { Satisfaction with area of } \\
\text { study }\end{array}$ & 24.14 & 4.84 & .90 & $.30^{* *}$ & $.35 * *$ & - & & & & \\
\hline 4 & Dropout intentions & 1.49 & 1.02 & - & $-.17 *$ & $-.30 * *$ & $-.68 * *$ & - & & & \\
\hline 5 & Iachan index & 16.54 & 8.51 & - & $.16^{*}$ & .01 & $.20 *$ & $-.26 * *$ & - & & \\
\hline 6 & Hexagonal index & 3.05 & 0.90 & - & .06 & -.08 & .12 & -.13 & $.67 * *$ & - & \\
\hline 7 & Zener-Schnuelle index & 3.44 & 2.80 & - & $.17 *$ & -.01 & $.16^{*}$ & $-.20 * *$ & $.90^{* *}$ & $.54 * *$ & - \\
\hline
\end{tabular}

Note: * $p<.05, * * p<.01$

First, because the significant correlations conditions were met, we performed the mediation analyses to test $\mathrm{H} 1$ and $\mathrm{H} 2$ (Figures 1 and 2). Self-efficacy alone is related with satisfaction with area of study, $b=0.09, \mathrm{t}(165)=4.07, p<.001$. Self-efficacy alone is related with dropout intentions, $b=-0.01, \mathrm{t}(165)=-2.16$, $p<.05$. Satisfaction with area of study alone is related with dropout intentions, $b=-0.15, \mathrm{t}(165)=-11.43, p<.001$. The direct effect of self-efficacy on dropout intentions becomes statistically insignificant once we consider satisfaction with 
area of study. The Sobel test in this case supports mediation $(z=-3.82, p<$ $.001)$. For $\mathrm{H} 2$, outcome expectations alone are related with satisfaction with area of study, $b=0.36, \mathrm{t}(165)=4.81, p<001$. Outcome expectations alone are related with dropout intentions, $\mathrm{b}=-.07, \mathrm{t}(165)=-4.04, p<001$. Satisfaction with area of study alone is related with dropout intentions, $b=-.14, \mathrm{t}(165)=$ $-10.63, p<.001$. The direct effect of outcome expectations on dropout intentions becomes statistically insignificant once we consider satisfaction with area of study. The Sobel test in this case supports mediation $(z=-4.37, p<.001)$. In conclusion, the results presented above show that in both cases, satisfaction with area of study is a full mediator and $\mathrm{H} 1$ and $\mathrm{H} 2$ are supported by the data.

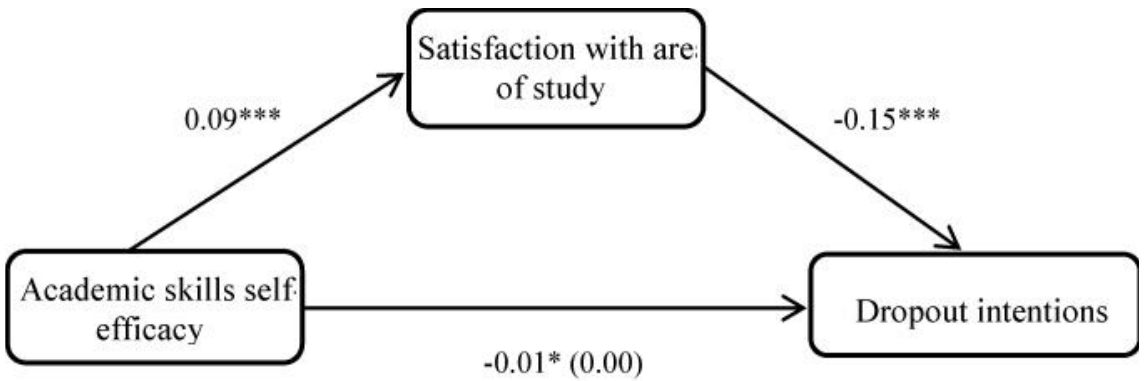

Note: * $p<.05, * * * p<.001$

Figure no. 1. Results of the mediation analysis, with satisfaction with area of study as a mediator between academic skills self-efficacy and dropout intentions

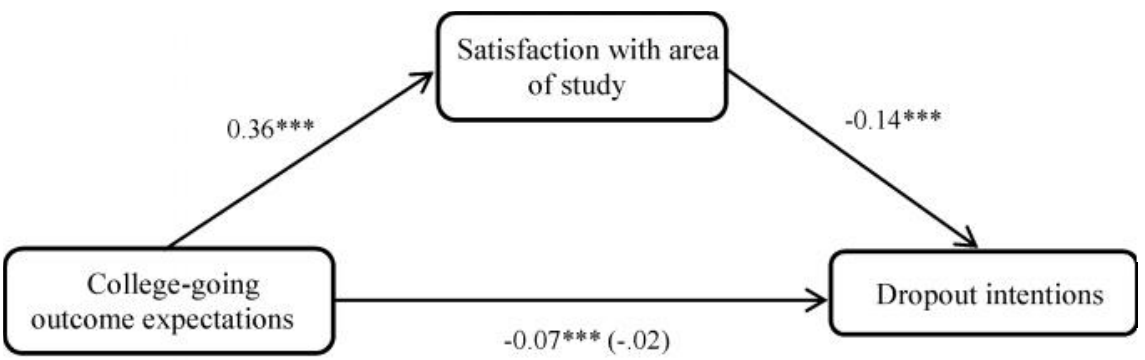

Note: $* * * p<.001$

Figure no. 2. Results of the mediation analysis, with satisfaction with area of study as a mediator between college-going outcome expectations and dropout intentions 
Furthermore, we tested different models in Mplus, in order to explore if vocational congruence has an incremental value over the social-cognitive factors in the prediction of dropout intentions. We used the Iachan and ZenerSchnuelle indices (the Hexagonal index was not used, because it was not related to the other variables).

In the first model (M1), we included the two mediations described above. Additionally, we included a path from self-efficacy to outcome expectations, which has been consistently supported in the literature (Lent \& Brown, 2019). In the second and third models (M2 and M3, respectively), in addition to $\mathrm{M} 1$, we included a path from vocational congruence (Iachan and ZenerSchnuelle, respectively) to satisfaction with area of study, because Holland's theory postulates that vocational congruence is a predictor for academic/job satisfaction. In the fourth and fifth models (M4 and M5), we also added a path from vocational congruence (Iachan and Zener-Schnuelle, respectively) to dropout intentions. For all models, we used latent variables. The fit indices for the 5 models are presented in Table no. 2. The results show that M1 has the best fit. M2 is not well fitted. In M3 and M5, although the fit indices are almost adequate, the paths from the Zener-Schnuelle congruence index are not significant. In M4, the paths from the Iachan congruence index are borderline significant $(p<.05)$. In conclusion, the best fitting model based on our data is M1, while models including congruence indices do not bring an increment in the prediction of dropout intentions. The visual representation of this model is shown in Figure no. 3.

Table no. 2. The goodness of fit statistics for the five variants of models of prediction of dropout intentions

\begin{tabular}{|c|c|c|c|c|c|c|c|}
\hline & $\chi^{2}$ & $D f$ & CFI & TLI & RMSEA & SRMR & WRMR \\
\hline M1 & $118.260^{*}$ & 6 & 0.999 & 0.998 & $0.013(0.000-0.154)$ & 0.020 & 0.319 \\
\hline M2 & $145.634^{*}$ & 9 & 0.966 & 0.925 & $0.083(0.000-0.160)$ & 0.032 & 0.500 \\
\hline M3 & $142.723^{*}$ & 9 & 0.980 & 0.955 & $0.063(0.000-0.144)$ & 0.028 & 0.477 \\
\hline M4 & $145.634^{*}$ & 9 & 0.994 & 0.983 & $0.040(0.000-0.142)$ & 0.021 & 0.345 \\
\hline M5 & $142.723^{*}$ & 9 & 0.993 & 0.979 & $0.044(0.000-0.144)$ & 0.024 & 0.400 \\
\hline
\end{tabular}

Note. $* \mathrm{p}<.0001$ 


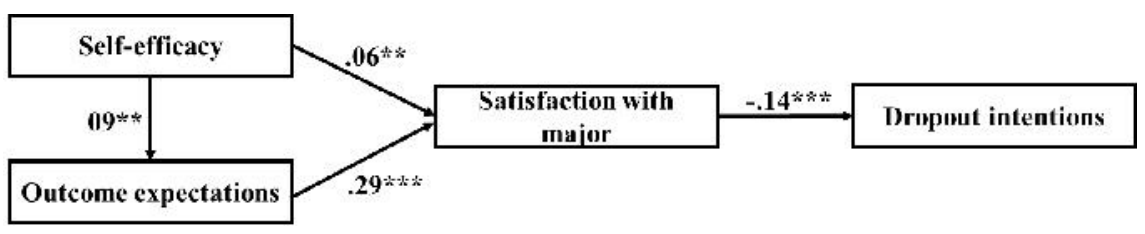

Note. $* * * \mathrm{p}<.001 ; * * \mathrm{p}<.01$

Figure no. 3. Structural path coefficients for M1

\section{Discussion}

The present study investigated the mediating effect of the satisfaction with the area of study in the relationships between self-efficacy and dropout intentions and between outcome expectations and dropout intentions; we also investigated whether Holland's congruence indices could be added to these models, for a better prediction of dropout intentions.

Both mediation hypotheses were supported by our data. This is in line with previous studies that investigated the SCCT integrative model (Lent et al., 2015; Lent et al., 2016). Those studies did not explore as outcome dropout intentions, but rather persistence intentions in the chosen area of study. Exploring dropout rather than persistence as an outcome makes more sense in Romania, because of the particularities of this context.

There are two specific features in our results that need to be discussed. In studies by Lent et al. (2013), Lent et al. (2015), and Lent et al. (2016), academic satisfaction was a partial mediator, while in our study it is a full mediator. All the effect of self-efficacy and outcome expectations is indirect, going through satisfaction with the area of study. While in previous studies self-efficacy emerged as the strongest predictor of intended persistence, for the Romanian sample, the strongest predictor is satisfaction with the area of study. This could be explained by the methodological design because self-efficacy and outcome expectations were assessed at the beginning of the freshman year, while satisfaction with the area of study and dropout intentions were assessed both at the same moment, after 6 months. 
Second, in previous studies, self-efficacy turned out to be the best predictor for academic satisfaction and persistence. In some studies, especially in longitudinal ones (Lent et al., 2016; Morris \& Lent, 2019), outcome expectations were not even a significant predictor. One interesting fact is that for our sample, outcome expectations are stronger predictors than selfefficacy for satisfaction with area of study $\left(\mathrm{r}^{2}=.12\right)$ and intention to dropout $\left(\mathrm{r}^{2}=.09\right)$. This explanatory power is even more relevant as it is obtained in a longitudinal design. This means that the satisfaction of students with their area of study comes less out of the feeling of capability, but rather out of working towards a goal (i.e., the expectation of things to happen after graduation). Future studies should investigate this characteristic in more depth. Cultural differences may play a part in this. For example, in common language in Romania, everybody asks: "what will you become after graduating from this faculty?" and not "what will you know/what will your competence be after graduating?".

The Holland congruence index is a predictor of dropout intentions in the form of Iachan and Zener-Schnuelle indices; the Hexagonal index is not a predictor of dropout intentions. The explanation could lie in the computation method for the 3 indices, with only 2 letter codes being computed for the Iachan and Zener-Schnuelle indices. Our results show that the only model in which there are significant paths from the Holland congruence indices to criteria is M5 - from the Iachan index to satisfaction with area of study and intention to drop out. However, the fit indices of the model are not better than those without the Iachan index, so our conclusion is that the congruence index does not bring an increment over social cognitive variables in explaining dropout intentions so that a model comprised only of social cognitive variables is explanatory enough.

\subsection{Theoretical and practical implications}

To our knowledge, this is the first study using the SCCT academic integrative model for the Romanian population. The study adds to the SCCT literature and validation studies by replicating the paths between the social-cognitive variables in a new culture. Also, although the model has been used in predicting persistence, this is the first longitudinal study that addresses dropout intentions. 
Recent literature recommends combining the SCCT with other theories in explaining vocational behavior (Brown \& Lent, 2019). In our study, we combined the SCCT with Holland's theory. The results show that although they are both very valid and well-studied theories in explaining human decision making, they are not useful when used together, at least for our criterion: the SCCT does a well enough job on its own in explaining dropout intentions.

The practical implications of this study are important, because of the need to devise interventions that decrease university dropout. The present investigation focused on socio-cognitive variables provides some answers in this respect. Our results show that academic self-efficacy and especially outcome expectations predict satisfaction with the area of study, which in turn predicts intentions to drop out. Consequently, the practical implication is that one way for universities to decrease students' intentions to drop out is to build their self-efficacy and outcome expectations in the first semester of the freshman year. A screening testing regarding these variables could be conducted in the first weeks at the university, as part of an "integration month" type of program. Group activities should be organized, in which students should be made systematically aware of the positive outcomes generated by graduating from university in general and from their specific area of study in particular. In these activities, academic staff should describe the opportunities awaiting after graduation, present possible jobs, organize conferences with the university alumni, etc., all with the goal of making students aware of the fact that they are in the right place that can help them to build their desired future. For those students scoring low on self-efficacy and outcome expectations, individual career counseling programs could be implemented. All these activities could be organized by the Career counseling and guidance centers available in universities.

One problem that should be addressed is the funding of these activities. The Ministerial document that governs the functioning of the career counseling and guidance centers (H.G. 650/2014) states a minimum ratio of a counselor/ psychologist per 2000 students. In practice, this number is reached by very few of the higher education career counseling centers. Another approach recommended in the literature is computing the return of investment for these activities (Johnson, 2000). They are legitimate, economically speaking, only if the amount of money lost from student dropout is higher than the 
amount spent on dropout interventions. Other sources of funding could be used for these types of activities.

\subsection{Limitations and future studies}

Several limitations should be mentioned. First, we studied intentions rather than actual drop out. There is no way of knowing how many of the participants will actually drop out. SCCT studies often mention as a limitation the fact that intention/goals are studied intensively, but few studies investigate the actual actions/implementation of career actions (Lent \& Brown, 2019). Stronger designs are also warranted, e.g. studies should investigate longitudinally one entire generation from a university area of study and explore retrospectively what combination of social-cognitive factors better predict academic dropout. However, this might prove to be challenging, because as the students become less and less involved in academic activities, they are also less prone to take part in psychological studies organized by the university. Another limitation is the small number of participants. Third, we draw attention to the sex distribution of our sample, containing many more female than male students; this may be a significant insofar as we know that there are differences between men and women with regard to types of preferred interests (Holland et al., 1994). Fourth, we used congruence indices based on two-letter Holland codes for the Iachan and Zener-Schnuelle indices, which might restrict the range of possible scores for these indices. It was not the case for the Hexagonal index, which is based only on the first letter. We did this because we compared individual codes with those of the possible qualifications offered by different areas of study, which can be very diverse with respect to secondary interest influences. More extended studies could use 3 letter indices.

The present study establishes a good replication of the most important relationships in the SCCT academic integrative model in a longitudinal design for a Romanian sample of freshmen students. It should be the base for further investigation into other variables from this model, such as environmental supports and barriers and personality traits. The results also inform future efforts by universities to build outcome expectations and selfefficacy in order to prevent dropout. 


\section{References}

- Asocia ia Na ională a Studen ilor din România. (2014). http://www.anosr.ro/ organizatiile-studentesti-ii-cer-ministrului-mihnea-costoiu-sa-isi-respectepromisiunile/

- Bean, J. P., \& Metzner, B. S. (1985). A conceptual model of nontraditional undergraduate student attrition. Review of Educational Research, 55(4), 485-540. https://doi.org/10.3102/00346543055004485

- Brown, S. D., \& Lent, R. W. (2019). Social Cognitive Career Theory at 25: progress in studying the domain satisfaction and career self-management models. Journal of Career Assessment, 27(4), 563-578.

https://doi.org/10.1177/1069072719852736

- Cabrera, A. F., Amaury, N., \& Castaneda, M. B. (1993). College persistence: structural equations modeling test of an integrated model of student retention. The Journal of Higher Education, 64(2), 123-139. https://doi.org/10.2307/2960026

- European Commission. (2010). EUROPE 2020. A strategy for smart, sustainable and inclusive growth.

https://eur-lex.europa.eu/legal-content/en/ALL/?uri=CELEX\%3A52010DC2020

- European Commission. (2019). Education and training monitor 2019. Country analysis. https://ec.europa.eu/education/sites/education/files/document-librarydocs/volume-2-2019-education-and-training-monitor-country-analysis.pdf

- Eurostat. (2020). Early leavers from education and training by sex and labour status. https://ec.europa.eu/eurostat/statistics-explainedindex.php?title=Early_ leavers_from_education_and_training

- Flores, L. Y., Navarro, R. L., Lee, H. S., Addae, D. A., Gonzalez, R., Luna, L. L., ... \& Mitchell, M. (2014). Academic satisfaction among Latino/a and White men and women engineering students. Journal of Counseling Psychology, 61(1), 81-92. https://doi.org/10.1037/a0034577

- Fu, M., Zhang, L. F., \& Li, B. (2019). Revisiting the congruence-satisfaction relationship: The role of external forces. Journal of Career Development, 46(3), 203-218. https://doi.org/10.1177/0894845317737379

- Garriott, P. O., Navarro, R. L., \& Flores, L. Y. (2017). First-generation college students' persistence intentions in engineering majors. Journal of Career Assessment, 25(1), 93-106. https://doi.org/10.1177/1069072716657533

- Gould, E. (2019). State of Working America Wages 2018. Wage Inequality Marches On—and Is Even Threatening Data Reliability. Economic Policy Institute.

- Grau-Valldosera, J., \& Minguillón, J. (2014). Rethinking dropout in online higher education: The case of the Universitat Oberta de Catalunya. International Review of Research in Open and Distributed Learning, 15(1), 290-308. https://doi.org/10.19173/irrodl.v15i1.1628 
- Hambleton, R. K., \& Zenisky, A. L. (2011). Translating and adapting tests for cross-cultural assessments. In D. Matsumoto \& F. J. van de Vijver (Eds.), Crosscultural research methods in psychology (pp. 46-70). Cambridge University Press.

- Hayes, A. F. (2013). Introduction to mediation, moderation, and conditional process analysis: a regression-based approach (1st ed.). The Guilford Press.

- Heublein, U. (2014). Student drop out from German higher education institutions. European Journal of Education, 49(4), 497-513.

https://doi.org/10.1111/ejed.12097

- Hoeschler, P., \& Backes-Gellner, U. (2017). Shooting for the stars and failing: college dropout and self-esteem (Working Paper No. 100).

http://repec.business.uzh.ch/RePEc/iso/leadinghouse/0100_lhwpaper.pdf

- Holland, J. L., Powell, A. B., \& Fritzsche, B. A. (1994). The self-directed search $(S D S)$. Psychological Assessment Resources.

- Holland, J. L., Powell, A. B., Fritzsche, B. A., Pitariu, H., Iliescu, D., \& Vercellino, D. (2010). Manual tehnic al SDS (Self-Directed Search) în România. OS România.

- IBM Corp. (2013). IBM SPSS Statistics for Windows (Version 22). IBM Corp.

- International Test Commission. (2005). International Guidelines on Test Adaptation. [www.intestcom.org].

- Iliescu, D., Ispas, D., Sulea, C., \& Ilie, A. (2015). Vocational fit and counterproductive work behaviors: A self-regulation perspective. Journal of Applied Psychology, 100(1), 21-39. https://doi.org/10.1037/a0036652

- Johnson, J. L. (2000). Learning communities and special efforts in the retention of university students: What works, what doesn't, and is the return worth the investment?. Journal of College Student Retention: research, theory \& practice, 2(3), 219-238.

https://doi.org/10.2190/V0PA-BL4B-1X2L-W5VT

- Landry, C. C. (2003). Self-efficacy, motivation, and outcome expectation correlates of college students' intention certainty (Doctoral dissertation).

http://digitalcommons.1su.edu/cgiviewcontent.cgi $?$ article=2253\&context= gradschool_dissertations

- Lee, Y., \& Choi, J. (2011). A review of online course dropout research: Implications for practice and future research. Educational Technology Research and Development, 59(5), 593-618.

- Lent, R. W., \& Brown, S. D. (2006). Integrating person and situation perspectives on work satisfaction: A social-cognitive view. Journal of Vocational Behavior, 69(2), 236-247. https://doi.org/10.1016/j.jvb.2006.02.006

- Lent, R. W., \& Brown, S. D. (2013). Social cognitive model of career selfmanagement: Toward a unifying view of adaptive career behavior across the life span. Journal of Counseling Psychology, 60(4), 557-568.

https://doi.org/10.1037/a0033446 
- Lent, R. W., \& Brown, S. D. (2019). Social cognitive career theory at 25: Empirical status of the interest, choice, and performance models. Journal of Vocational Behavior, 115, 103316. https://doi.org/10.1016/j.jvb.2019.06.004

- Lent, R. W., Brown, S. D., \& Hackett, G. (1994). Toward a unifying social cognitive theory of career and academic interest, choice, and performance. Journal of Vocational Behavior, 45(1), 79-122.

- Lent, R. W., Miller, M. J., Smith, P. E., Watford, B. A., Hui, K., \& Lim, R. H. (2015). Social cognitive model of adjustment to engineering majors: Longitudinal test across gender and race/ethnicity. Journal of Vocational Behavior, 86, 77-85. https://doi.org/10.1016/j.jvb.2014.11.004

- Lent, R. W., Miller, M. J., Smith, P. E., Watford, B. A., Lim, R. H., \& Hui, K. (2016). Social cognitive predictors of academic persistence and performance in engineering: Applicability across gender and race/ethnicity. Journal of Vocational Behavior, 94, 79-88. https://doi.org/10.1016/j.jvb.2016.02.012

- Lent, R. W., Miller, M. J., Smith, P. E., Watford, B. A., Lim, R. H., Hui, K., ... \& Williams, K. (2013). Social cognitive predictors of adjustment to engineering majors across gender and race/ethnicity. Journal of Vocational Behavior, 83(1), 22-30. https://doi.org/10.1016/j.jvb.2013.02.006

- Morris, T. R., \& Lent, R. W. (2019). Heterosexist harassment and social cognitive variables as predictors of sexual minority college students' academic satisfaction and persistence intentions. Journal of Counseling Psychology, 66(3), 308-316. https://doi.org/10.1037/cou0000341

- Mujica, A. D., Villalobos, M. V. P., Gutiérrez, A. B. B., Fernández-Castañón, A. C., \& González-Pienda, J. A. (2019). Affective and cognitive variables involved in structural prediction of university dropout. Psicothema, 31(4), 429-436. https://doi.org/10.7334/psicothema2019.124

- Muthén, L. K., \& Muthén, B. O. (1998-2012). Mplus User's Guide. Seventh Edition. Muthén \& Muthén.

- Nauta, M. M. (2007). Assessing college students' satisfaction with their academic majors. Journal of Career Assessment, 15(4), 446-462. https://doi.org/10.1177/1069072707305762

- Navarro, R. L., Flores, L. Y., Lee, H. S., \& Gonzalez, R. (2014). Testing a longitudinal social cognitive model of intended persistence with engineering students across gender and race/ethnicity. Journal of Vocational Behavior, 85(1), 146-155. https://doi.org/10.1016/j.jvb.2014.05.007

- Nye, C. D., Su, R., Rounds, J., \& Drasgow, F. (2012). Vocational interests and performance: A quantitative summary of over 60 years of research. Perspectives on Psychological Science, 7(4), 384-403. https://doi.org/10.1177/1745691612449021

- Robbins, S. B., Lauver, K., Le, H., Davis, D., Langley, R., \& Carlstrom, A. (2004). Do psychosocial and study skill factors predict college outcomes? A meta- 
analysis. Psychological Bulletin, 130(2), 261-288.

https://doi.org/10.1037/0033-2909.130.2.261

- Rodríguez-Gómez, D., Feixas, M., Gairín, J., \& Muñoz, J. L. (2015). Understanding Catalan university dropout from a cross-national approach. Studies in Higher Education, 40(4), 690-703. https://doi.org/10.1080/03075079.2013.842966

- Sander, P., \& Sanders, L. (2009). Measuring academic behavioural confidence: the ABC scale revisited. Studies in Higher Education, 34(1), 19-35. https://doi.org/10.1080/03075070802457058

- Stăiculescu, C., \& Richi eanu-Năstase, E. R. (2018). University dropout. Causes and solution. Mental Health: Global Challenges Journal, 1(1), 71-75.

- Tinto, V. (1975). Dropout from higher education: A theoretical synthesis of recent research. Review of Educational Research, 45(1), 89-125. https://doi.org/10.3102/00346543045001089

- Tracey, T. J., \& Robbins, S. B. (2006). The interest-major congruence and college success relation: A longitudinal study. Journal of Vocational Behavior, 69(1), 64-89. https://doi.org/10.1016/j.jvb.2005.11.003

- Truong, N. N., \& Miller, M. J. (2018). Family and social cognitive predictors of southeast Asian American college students' academic satisfaction. Journal of Career Assessment, 26(3), 488-502. https://doi.org/10.1177/1069072717714543

- Tsabari, O., Tziner, A., \& Meir, E. I. (2005). Updated meta-analysis on the relationship between congruence and satisfaction. Journal of Career Assessment, 13(2), 216-232. https://doi.org/10.1177/1069072704273165

- Varly, P., Iosifescu, C. Ş., Fartuşnic, C., Andrei, T., \& Her eliu, C. (2015). Costul investi iei insuficiente în educa ie în România: raport final pentru UNICEF. Alpha MDN.

The online version of this article can be found at: http://revped.ise.ro/category/2020-en/

\section{(c) EY-NG-sA}

This work is licensed under the Creative Commons Attribution-NonCommercial-ShareAlike 4.0 International License.

To view a copy of this license, visit http://creativecommons.org/licenses/by-nc-sa/4.0/ or send a letter to Creative Commons, PO Box 1866, Mountain View, CA 94042, USA.
Versiunea online a acestui articol poate fi găsită la: http://revped.ise.ro/category/2020-ro/

\section{$( c c ) \longdiv { B R - N C - s h }$}

Această lucrare este licen iată sub Creative Commons Attribution-NonCommercial-ShareAlike 4.0 International License.

Pentru a vedea o copie a acestei licen e, vizita $i$ http://creativecommons.org/licenses/by-nc-sa/4.0/ sau trimite i o scrisoare către Creative Commons, PO Box 1866, Mountain View, CA 94042, SUA. 


\section{INDUCEREA RUŞINII ŞI VINOVĂ IEI ÎN CONDUCEREA ŞI FACILITAREA ACTULUI DE ÎNVĂ ARE AL ŞCOLARULUI MIC: RELA IA CU DEZVOLTAREA SIMPTOMATOLOGIEI ASOCIATE ANXIETĂ II}

\section{Leti ia Anculete*}

Spitalul de Obstretrică-Ginecologie „Dr. Maria Burghele” Buftea,

Buftea, România

letitia.anculete@yahoo.com

Gra iela Sion**

Universitatea Spiru Haret,

Departamentul de Pregătire a Personalului Didactic,

Bucureşti, România

gratielasion@gmail.com

\section{Rezumat}

Impunerea şi controlul actului de învă are fac uz de emo iile auto-reflexive de ruşine şi vinovă ie ale şcolarului mic, acestea generând simptomatologie, comportamente şi atitudini asociate anxietă ii (frica de evaluare, frauda - ca formă a fricii de eşec, teama de a vorbi în fa a clasei, teama de a adresa întrebări etc.).

Tulburările de anxietate tind să înceapă devreme în via ă şi dau naştere unei cascade de consecin e negative pe termen lung. O meta-analiză a vârstei de debut pentru tulburările de anxietate arată că anxietatea de separare şi fobia specifică au o vârstă de debut de la 10 la 11 ani şi indică faptul că anii de şcoală primară ar putea fi o fază de risc semnificativă pentru dezvoltarea tulburărilor de anxietate.

Cercetarea a fost condusă în perioada ianuarie 2018 - mai 2019 în 10 localită i urbane

* Psiholog Clinician, Psihoterapeut, Spitalul de Obstretrică-Ginecologie „Dr. Maria Burghele" Buftea, Buftea, România.

** Conf. univ. dr., Psihoterapeut specialist - Formator, Departamentul de Pregătire a Personalului Didactic, Universitatea Spiru Haret, Bucureşti, România. 
şi rurale, în rândul a 341 de copii din 20 de institu ii de învă ământ din România, dar şi a părin ilor acestora şi a cadrelor didactice (23 de responden i), utilizând ancheta pe bază de chestionar omnibus, pentru măsurarea nivelului corela iilor dintre ruşine, vinovă ie şi simptomele clinice asociate anxietă ii la şcolari.

Un obiectiv al cercetării a fost verificarea măsurii în care anxietatea este observabilă în familie şi în sistemul educa ional. Analiza datelor a relevat o corela ie între ruşine şi vinovă ie şi comportamentele marcate de anxietate. Totodată, s-a constatat că nu există diferen e de manifestare a simptomelor anxioase între mediul şcolar şi cel familial şi că - în general - părin ii şi cadrele didactice pot observa caracteristicile comportamentale şi atitudinale ce semnalează prezen a anxietă ii.

Cuvinte-cheie: anxietate, mediu educa ional, ruşine, vinovă ie.

\section{Abstract}

Imposing and controlling learning actions which use the self-reflective emotions of shame and guilt of the school students, generate symptoms, behaviors and attitudes associated with anxiety (fear of evaluation, fraud-generated by fear of failure, fear of speaking in front of the classroom, fear of asking questions, etc.). Anxiety disorders tend to start early in life and give rise to long-term negative consequences. A meta-analysis of the onset age for anxiety disorders shows that separation anxiety and specific phobia have an onset 10 to 11 years of age and indicates that elementary school years could be a significant risk phase for the development of the anxiety disorders.

The research was conducted between January 2018 and May 2019 in 10 urban and rural communities in Romania. 341 school children aged between 5 and 12 years old, from 20 Romanian educational institutions, participated together with their parents and teachers (23 respondents), using an omnibus questionnaire which measures the level of correlations between shame, guilt and clinical symptoms associated with anxiety in children.

One of the research objectives was to verify the extent to which anxiety is observable in the school and family environment. The results revealed a correlation between shame, guilt and anxiety. At the same time, it was found that there were no differences between school and family environment in terms of anxiety symptoms, and that - in general - parents and teachers could observe the behavioral and attitudinal characteristics that signal the presence of anxiety.

Keywords: anxiety, educational environment, guilt, shame. 


\section{Studii şi cercetări cu privire la ruşine şi vinovă ie}

Ruşinea şi vinovă ia ajută oamenii să evite să facă greşeli? Este întrebarea cu care începe raportul unui studiu din 2015 cu privire la înclina ia copiilor pentru ruşine şi vinovă ie ca predictor în comportamente riscante şi ilegale la vârsta adultă (Stuewig et al., 2015). Stuewig, Tangney şi Dearing au studiat ruşinea şi vinovă ia pe parcursul a mai multe decenii şi au arătat că persoanele care au tendin a de a sim i ruşine în exces au adesea o stimă de sine scăzută (ceea ce înseamnă, deopotrivă, că stima de sine crescută poate proteja persoana de sentimentele de ruşine excesive). Tangney şi Dearing (2002) sunt printre autorii care au descoperit că predispozi ia la a resim i ruşine în exces poate creşte şi riscul pentru alte probleme psihologice.

Cercetări empirice şi teoretice recente au facilitat crearea unor distinc ii conceptuale puternice între ruşine şi vinovă ie. Anterior ultimelor decenii, ruşinea şi vinovă ia au fost utilizate în mod substan ial nediferen iat, acum fiind recunoscute ca emo ii distincte ce promovează tendin e de ac iune sau motiva ii diferite. Nerespectarea comportamentului considerat social dezirabil şi adecvat, precum şi tensiunea acumulată în anticiparea acestor emo ii, poate predispune o persoană să simtă vinovă ia sau ruşinea (Ferguson et al., 2000). Deşi con in caracteristici de bază similare, autorii sunt de obicei de acord că ruşinea şi vinovă ia sunt emo ii diferite, descriu propriile rela ii, antecedente şi consecin e în sănătatea mintală (Tangney et al., 2007).

O perspectivă clară asupra acestor distinc ii a permis dezvoltarea unei literaturi de specialitate care vizează evaluarea asocierilor diferen iale dintre ruşine şi vinovă ie, cu simptome anxioase şi depresive. Într-un studiu din 2009, au fost analizate în mod special efectele predispozi iei la ruşine asupra simptomelor depresive la preadolescen i şi adolescen i. Proiectul a cuprins aproximativ 140 de voluntari cu vârste cuprinse între 11 şi 16 ani şi a descoperit că adolescen ii care au prezentat o mai mare predispozi ie de a resim i ruşine aveau, de asemenea, mai multe şanse să aibă simptome de depresie (De Rubeis \& Hollenstein, 2009). Este eviden iată, de asemenea, o legătură între predispozi ia de a resim i ruşine şi anxietate, tulburarea de anxietate socială şi tulburarea de anxietate generalizată (Fergus et al., 2010). Ruşinea excesivă este asociată cu probleme de anxietate socială, rumina ie, depresie (Ferguson et al., 1999). 
Pentru a experimenta ruşinea şi vinovă ia este necesar un nivel de conştiin ă de sine şi deci de reflectare asupra sinelui, în elegerea de norme şi valori, precum şi responsabilitatea de a le respecta (Kim et al., 2011; Tracy, Robins \& Tangney, 2007). Aşadar, ruşinea şi vinovă ia sunt aşezate în categoria „emo iilor auto-reflexive” (Tangney, 1990). Fa ă de emo iile de bază sau primare, cum ar fi furia, mânia, bucuria şi fericirea, emo iile auto-reflexive implică mai multă complexitate cognitivă şi, prin urmare, sunt experimentate mai târziu în dezvoltare (Kim et al., 2011). Emo iile auto-reflexive presupun dezvoltarea conştiin ei de sine, a reprezentării de sine şi în elegerea standardelor utilizate în compara ia socială cu al i oameni, apărând mult mai târziu decât emo iile primare sau de bază (de exemplu, frică - opt-zece luni; furie - patru-şase luni; bucurie - trei luni) (Stănculescu, 2011).

Unele emo ii auto-reflexive încep a se dezvolta în cel de-al doilea an de via ă, dar majoritatea, inclusiv vinovă ia, apar în cursul celui de-al treilea an (Stănculescu, 2011).

Sentimentele de vinovă ie semnalează un comportament inacceptabil sau indezirabil social şi motivează ac iuni reparatorii pentru a uşura tensiunea creată (Lewis, 1971; Tangney et al., 2007). Vinovă ia este recunoscută pentru a consolida legăturile sociale şi ataşamentul, trezind dorin a pentru apropierea de ceilal i (Baumeister et al., 1994; Ferguson et al., 1991).

Această emo ie apare ontogenetic după vârsta de doi ani, când copilul este capabil să în eleagă că se află într-o stare de dependen ă de ceilal i (părin i), de sprijinul şi iubirea lor. Atunci când intensitatea vinovă iei este dispropor ionată, este posibil să se transforme într-o experien ă copleşitoare. Capacitatea de a sim i culpabilitatea, la un nivel adecvat gravită ii situa iei care provoacă emo iile de vinovă ie, reflectă începutul maturită ii afective şi capacitatea de a realiza rela ii interpersonale sănătoase (Stănculescu, 2011). Alte studii arată că vinovă ia a fost asociată cu mijloace constructive de combatere a furiei (Tangney \& Dearing, 2002; Tangney, Wagner, Hill-Barlow, Marschall \& Gramzow, 1996), cu comportamentul prosocial (Menesini \& Camodeca, 2008; Olthof, 2012) şi niveluri scăzute de agresiune (Roos et al., 2011; Roos et al., 2014; Tangney et al., 1992; Tangney et al., 1996). O lipsă cronică de vinovă ie este un semn distinctiv al unei tinere i extrem de agresive (Frick \& White, 2008). 
Aşadar, experien a vinovă iei este adesea înso ită de un sentiment de tensiune, de remuşcare şi de regret pentru ac iunile care au încălcat normele şi, în loc să provoace răspunsurile defensive şi de represalii care sunt caracteristicile ruşinii, acest sentiment de tensiune şi regret tinde să motiveze ac iunea reparatorie, ca de exemplu, mărturisirea, scuzarea, repara ia (De Hooge et al., 2007; Ketelaar \& Au, 2003, Lewis, 1971; Sheikh \& Janoff-Bulman, 2010; Tangney, Miller, Flicker \& Barlow, 1996; Tangney et al., 1996).

Unii autori consideră că este posibil ca sentimentele de vinovă ie să fie mai predispuse la schimbări constructive ale comportamentului viitor, deoarece ceea ce este în discu ie nu este un sine defectuos, ci un comportament defectuos.

Privitor la sentimentele de ruşine, cei mai mul i autori sunt de acord că sunt generate de evaluarea negativă a sinelui. Aceasta implică confruntarea cu ceea ce ei numesc ,identitate nedorită” (Olthof et al., 2000) şi teama pentru evaluările sinelui nedorit de către ceilal i. Sentimentele de ruşine implică o concentrare dureroasă asupra sinelui, iar experien a ruşinii este adesea înso ită de un sentiment de lipsă de valoare, neputin ă, micşorare şi expunere (Tangney et al., 1992).

Deoarece ruşinea este greu tolerabilă, oamenii afla i în mijlocul unei experien e ruşinoase recurg adesea la oricare dintre o serie de modalită i defensive, precum căutarea de a ascunde faptele sau pe sine, sau încercarea de a scăpa de sentimentul ruşinos negând responsabilitatea (Lewis, 1971; LindsayHartz et al., 1995; Tangney et al., 1996). Un alt comportament frecvent în situa ia ruşinii copleşitoare este cel de externalizare a vinovă iei şi de a implica pe ceilal i ca fiind responsabili de ac iunea care de fapt le apar ine (Stuewig et al., 1996; Stuewig et al., 2010). Asocierea cu comportamentele agresive este şi ea bine documentată, indicând că ruşinea excesivă conduce la comportamente de furie, ac iuni ira ionale în care îi implică pe al ii şi care pot ajunge uneori la ac iuni excesiv de agresive şi distructive (Tangney et al., 1996).

Unii autori sugerează (Stuewig et al., 2010) că ruşinea ar trebui să fie pozitiv legată de agresiune, în timp ce vinovă ia poate servi drept factor de protec ie, cu toate că aici autorii consideră că sunt necesare studii mai aprofundate pentru clarificări. 
Cercetările au mai arătat că tendin a de a experimenta ruşinea este asociată cu o varietate de probleme psihologice: anxietate, depresie, comportamente obsesiv-compulsive, psihotism, precum şi tulburare de stres posttraumatică (Ferguson et al., 2000; Orth et al., 2006; Tangney et al., 1992).

Un studiu ob inut din meta-analiza a 108 cercetări care au angajat 22.411 participan i (Kim et al., 2011) s-a concentrat pe a rezuma cantitativ amploarea asocierilor ruşinii şi vinovă iei cu simptomele depresive. Astfel, au fost înregistrate asocieri semnificativ mai slabe ale vinovă iei decât ale ruşinii, cu simptomele depresive. Pe de altă parte, asocierea vinovă iei cu simptomele de depresie a fost nediferen iată statistic de asocierea a două variante inadaptative ale vinovă iei: vinovă ia contextual-inadaptativă, implicând responsabilitatea exagerată pentru evenimente incontrolabile, şi vinovă ia generalizată, care inundă, implicând vinovă ia separată de contextele concrete.

În general însă, se pare că ruşinea este adesea emo ia mai distructivă. Putem afirma, aşadar, că părin ii şi profesorii, precum şi to i cei implica i în creşterea şi educa ia copiilor, ce doresc să încurajeze un comportament de răspuns constructiv al copiilor, ar fi bine să evite utilizarea metodelor de interac iune (în cadrul procesului didactic şi al parentajului) care conduc la ruşine şi vinovă ie, alegând în schimb să îi ajute pe copii să în eleagă efectele ac iunilor lor asupra celorlal i şi să producă ac iuni reparatorii şi auto-corective.

Donald L. Nathanson (D.L. Nathanson, interviu, 8 Septembrie 2003), un autor consacrat al domeniului de studiu privind ruşinea şi vinovă ia, creator al modelului teoretic denumit „Busola ruşinii”, în interviul privind rolul afectelor în învă are, respectiv modul cum ruşinea exacerbează dificultă ile de citire, face o observa ie pertinentă: când ne gândim la educa ie - spune el - şi la procesul de educa ie, deseori ac ionăm ca şi cum educa ia este doar despre felul în care un copil primeşte informa ii şi le prelucrează.

Spre surprinderea majorită ii oamenilor, educa ia se referă şi la emo ie, spune autorul. Momentul ruşinii îi face pe copii să nu poată gândi clar. Nathanson numeşte acest moment "şoc cognitiv" şi îl pozi ionează într-un tablou de mecanisme fiziologice. Şocul cognitiv produce reflectarea asupra şi a altor experien e pe care copilul le-a avut legat de această ruşine. Experien e de ineficien ă, inadecvare, nepregătire inundă şi, dintr-odată, mentalul nu mai 
este focalizat asupra materialului tipărit pe pagină sau asupra sarcinii, ci este confruntat cu o mul ime de experien e similare legate de ruşine şi care au de-a face cu acel sine indezirabil, cel mai rău sine posibil.

Într-o situa ie de învă are în clasă, acel moment de ruşine poate deveni copleşitor pentru copilul care se poate sim i expus. Situa ia diferă atunci când învă area are loc ,unul-la-unul” acasă, alături de persoane care oferă siguran ă şi sus inere, momentul de ruşine nefiind atât de toxic. Dar când este la şcoală şi învă area are loc în clasă, pentru copil există riscul constant de ruşine, greşelile sale sunt subiectul discu iei între colegi, al corec iei aspre sau inferiorizante, rezultatul cu valoare scăzută deseori fiind identificat cu persoana copilului. Pentru copilul care este în proces de învă are a citirii, o performan ă slabă poate duce la teama de a nu fi asimilat şi redus la ea.

Cu cât un copil are mai multe probleme de citire într-o situa ie de clasă, continuă Nathanson, cu atât este mai probabil ca acesta să experimenteze ruşine şi să afecteze interesul normal pentru activitatea de lectură. Retragerea ca răspuns la ruşine este una din cele mai frecvente atitudini. Mai mult, ruşinea experimentată frecvent adânceşte incapacitatea: cu cât mai des copilul experimentează întreruperea de la exersarea lecturii, pe care o realizează ocupându-se cu sentimentele de ruşine, cu atât mai pu in sau mai lent va evolua în învă are. Nathanson arată că răspunsul normal la ruşine este accentuarea ambiguită ii şi a confuziei.

Experien ele legate de ruşine oferă copilului răspunsuri despre cine este el şi are consecin e uriaşe asupra modului în care se vede în raport cu ceilal i; ca urmare, spune Nathanson, îl obligă la a se apăra de acest sentiment negativ într-o serie de moduri pe care le numeşte „Busola ruşinii” (Compass of Shame). Cei patru poli ai Busolei ruşinii sunt: retragerea, atac asupra sinelui, evitarea şi atac asupra celuilalt. Destul de curând, copilul înva ă to i cei patru poli. Rolul lecturii în acest context este destul de important, consideră autorul Busolei, pentru că este experien a majoră pe care o au copiii când intră în procesul de educa ie şi, dacă se confruntă cu eşecul şi nu pot citi, atunci ei sunt expuşi unei cantită i inutile de experien ă legată de ruşine, pe care trebuie să o depăşească, atunci când ei sunt cel mai pu in pricepu i la a gestiona sentimentul complex care este ruşinea. 
Societatea oferă multe modalită i de a repara situa iile care provoacă vinovă ie, inclusiv scuze, plata unor penalită i financiare şi executarea unor pedepse; în acelaşi sens, ritualurile religioase, cum ar fi confesiunea, spovedania, pot ajuta, de asemenea, să ne confruntăm cu vinovă ia, de aceea copingul legat de vinovă ie este adesea mai facil decât depăşirea ruşinii. Ruşinea are o persisten ă mult mai dăunătoare pentru că pare că este mult mai uşoară acceptarea unor comportamente dăunătoare sau indezirabile decât acceptarea de sine.

\section{Studiu asupra emo iilor auto-reflexive de ruşine şi vinovă ie ale şcolarului mic în mediul şcolar şi familial: rela ia cu dezvoltarea simptomatologiei, comportamentelor şi atitudinilor asociate anxietă ii}

\subsection{Obiective}

Acest studiu a urmărit verificarea existen ei unei corela ii între nivelul ruşinii şi vinovă iei şi comportamentele / atitudinile marcate de anxietate la copiii şcolari, verificarea măsurii în care anxietatea este observabilă în familie şi în mediul educa ional, iar pe de altă parte, verificarea existen ei unor diferen e de manifestare a simptomelor anxioase la copil în mediul şcolar fa ă de cel familial.

\subsection{Caracteristicile lotului de responden $\mathrm{i}$}

Având în vedere că cercetarea a implicat copii, părin i şi cadre didactice, a fost urmărită respectarea confiden ialită ii, prin reducerea datelor de identificare consemnate (de exemplu, pentru copii s-au solicitat doar ini ialele numelui şi vârsta), şi prin solicitarea făcută responden ilor părin i, de a sigila în plic chestionarele autoadministrate.

Lotul de cercetare este compus din 341 copii, precum şi părin ii acestora (341) şi 23 de cadre didactice (învă ători şi dirigin i). Responden ii sunt copii şcolari cu vârste cuprinse între 5 şi 12 ani, înrola i în clasele 1-5, provenind din mediul urban şi rural. Cercetarea a fost condusă în şcoli din jude ele Prahova, Argeş, Teleorman, Ilfov, Dâmbovi a, Giurgiu şi Bucureşti, lotul de responden i copii fiind compus din 162 de fete (reprezentând un procent de 
47,5\% din totalul participan ilor) şi 179 de băie i (reprezentând un procent de 52,5\%), cu o medie de vârstă de 9,35 ani (std. dev: 1,643).

\subsection{Metoda de cercetare}

Studiul a utilizat o metodă cantitativă, respectiv ancheta pe bază de chestionar administrat (copiilor şcolari) şi autoadministrat (pentru cadrele didactice şi părin i), astfel:

- un chestionar de tip omnibus administrat de către operatorii de interviu copiilor, con inând: date factuale (genul, vârsta, clasa), chestionarul Brief Shame Guilt Questionnaire for Children (BSGQ-C - tradus şi adaptat după Novin şi Rieffe, 2015, cu acordul autorilor), chestionarul Revised Children's Anxiety and Depression Scale (RCADS-25 for Children tradus şi adaptat după Chorpita, Ebesutani şi Spence, 2015, cu acordul autorilor). Chestionarul BSGQ-C este compus din 6 itemi pentru dimensiunea „Ruşine” şi 6 itemi pentru dimensiunea „Vinovă ie”, în timp ce chestionarul RCADS- 25 for Children este compus din 25 de itemi care măsoară nivelul anxietă ii şi al depresiei la copii;

- chestionarul Revised Children's Anxiety and Depression Scale for Caregiver autoadministrat de către părin i şi cadrele didactice (RCADS25 for Caregiver - tradus şi adaptat după Chorpita, Ebesutani şi Spence, 2015, cu acordul autorilor). Chestionarul RCADS-25 for Caregiver este compus din 25 de itemi care măsoară nivelul anxietă ii şi al depresiei la copii, evaluarea făcându-se prin intermediul părin ilor şi/sau cadrelor didactice.

Atât instrumentul BSGQ-C, cât şi RCADS-25 for Children şi RCADS-25 for Caregiver, au înregistrat o bună consisten ă internă după traducerea şi adaptarea în limba română (BSGQ-C: á=.779; RCADS-25-Children á= .864, RCADS-25-Caregiver: á=.866).

\subsection{Rezultate}

Analiza datelor arată că ruşinea nu corelează cu vârsta, ceea ce înseamnă că nivelul ruşinii nu creşte, ci tinde să rămână constant în func ie de vârstă. 
Elementele de maturizare nu produc diferen e, competen ele crescute provenite din evolu ia în vârstă nu arată şi creşterea competen elor de gestionare a răspunsurilor bazate pe ruşine, în contextul situa iilor de via ă. Studiul arată că, până la vârsta de 12 ani, copilul şcolar nu are în mod independent, fără îndrumare specifică, capacitatea de a diminua răspunsurile bazate pe ruşine, atunci când ele sunt disfunc ionale.

Pe de altă parte, vinovă ia corelează slab pozitiv, cu diferen e semnificative, cu vârsta (r=.144, p=.008), copiii mai mari resim ind mai des sentimente de vinovă ie.

Studiul a urmărit să verifice măsura în care anxietatea este observabilă în familie şi în sistemul educa ional. Scorurile înregistrate de copii pentru RCADS-25 (simptomele de depresie şi de anxietate) au corelat mediu semnificativ cu răspunsurile părin ilor $(r=.430, p=.000)$ şi slab pozitiv, cu diferen e semnificative, cu cele ale cadrelor didactice $(\mathrm{r}=.245, \mathrm{p}=.000)$. Totuşi, pentru 159 de copii din cei 341, rata mare a non-răspunsurilor din partea cadrelor didactice, anularea unor chestionare pentru răspunsuri inconsistente, precum şi corela iile de mai sus, arată o reticen ă fie în exprimarea răspunsurilor, fie în aprecierea situa iilor.

Studiul a urmărit, de asemenea, măsura în care ruşinea şi vinovă ia corelează cu simptomele anxioase. Datele au arătat că ruşinea şi vinovă ia la copiii şcolari cu vârsta până în 12 ani corelează slab pozitiv, cu diferen e semnificative (ruşine: $r=.123, p=.023$ şi vinovă ie: $r=.256, p=.008$ ), cu simptomele anxioase şi depresive (RCADS-25).

Totodată, s-a constatat că nu există diferen e de manifestare a simptomelor anxioase între mediul şcolar şi cel familial şi că - în general - părin ii şi cadrele didactice pot observa caracteristicile comportamentale şi atitudinale ce semnalează prezen a anxietă ii. Scorurile RCADS-25 pentru părin i şi pentru cadre didactice au corelat slab pozitiv, cu diferen e semnificative $(\mathrm{r}=.254, \mathrm{p}=.000)$.

\section{Concluzii, discu ii şi recomandări}

O limită întâlnită în evaluările părinte - copil, care trebuie luată în discu ie şi 
în cercetarea de fa ă, este dată de starea de moment a părintelui, atunci când acesta relatează anumite comportamente şi simptome (Friedberg et al., 2013). Cu alte cuvinte, corela ia slab pozitivă dintre răspunsurile date de copil şi cele date de părinte poate fi generată şi de dispozi ia acestuia din urmă. Diferen ele de evaluare copii - părin i - profesori sunt date de motiva iile şi obiectivele diferite: părin ii pot privi evaluarea ca pe un proces de identificare a problemelor, copiii pot avea ca scop minimizarea problemelor etc. Totodată, autorii au mai arătat că, în timp ce părin ii privesc copilul ca fiind sursa problemei respective, copilul priveşte problema ca inând de un alt context; alte studii au arătat că părin ii tind să evalueze mai corect comportamentele şi problemele de externalizare, în timp ce copiii pot relata cu acurate e propriile trăiri emo ionale (Friedberg et al., 2013).

$\mathrm{Cu}$ toate acestea, se recomandă în evaluarea clinică a copiilor cu privire la manifestările anxioase şi utilizarea relatărilor părin ilor. Prin identificarea punctelor de convergen ă şi divergen ă, autorii (Friedberg et al., 2013) au arătat cum apar factori noi de luat în calcul pentru o interven ie, cum ar fi: măsura în care părin ii tind să minimalizeze sau să amplifice simptomatologia copilului, precum şi măsura în care copilul poate să-şi observe propriile comportamente şi trăiri. În plus, atunci când atât părintele, cât şi copilul au scoruri asemănătoare pentru un anumit item, aceasta constituie o dovadă clară că acea problemă este relevantă pentru studiu.

Comparativ cu studiile men ionate, lucrarea de fa ă include şi cadrele didactice. Deşi prezintă limitări precum cele arătate mai sus, datele studiului sunt consistente în legătură cu posibilitatea părin ilor şi a cadrelor didactice de a observa tabloul manifestărilor anxioase la copil. Cu toate acestea, răspunsurile cadrelor didactice au corelat mai slab cu răspunsurile copiilor decât cele ale părin ilor. Rata mare a non-răspunsurilor din partea cadrelor didactice, anularea unor chestionare pentru răspunsuri inconsistente, precum şi corela iile din analiză, sprijină concluziile noastre conform cărora este necesară sus inerea cadrelor didactice prin oferte de educa ie psihologică aplicată.

De asemenea, datele arată că nu există diferen e de manifestare a simptomelor anxioase între mediul şcolar şi cel familial, copiii fiind înclina i să manifeste aceleaşi comportamente la şcoală ca şi acasă. Ca urmare, în 
ambele medii ei pot fi identifica i timpuriu în legătură cu predispozi iile către anxietate şi pot fi dezvoltate metode de preven ie. De asemenea, o bună comunicare şi un parteneriat autentic între şcoală şi familie ar putea confirma observa iile ambelor păr i sau aduce date noi.

Atât părin ii cât şi cadrele didactice au nevoie să cunoască importan a emo iilor autoreflexive în procesele de învă are, să fie antrena i în metode de diminuare a comportamentelor de apărare negative ca răspuns la ruşine şi vinovă ie, cum ar fi retragerea, abandonul sarcinilor, izolarea, răspunsurile agresive sau ostile.

Studiul a ob inut date care sus in perspectiva conform căreia ruşinea şi vinovă ia la copiii cu vârste cuprinse între 5 şi 12 ani pot fi asociate cu simptomele anxioase şi depresive, ca urmare discu iile care se deschid aici pot fi conduse în mai multe direc ii.

Utilizarea în exces de către adul ii responsabili de educa ie a metodelor de interac iune care predispun copilul la răspunsuri de ruşine şi vinovă ie pare să facă parte dintr-o convingere tradi ională că ruşinea şi vinovă ia sunt mai degrabă benefice dezvoltării. Studiul de fa ă sprijină perspectiva în care modalită ile de interac iune cu copilul în educa ie sunt bazate pe identificarea practicilor şcolare, a ac iunilor profesorilor şi a interac iunilor dintre elevi care generează ruşinea, considerând că acesta este primul pas în a face din şcoală un loc mai bun pentru învă are şi dezvoltare. Următorul pas este căutarea şi promovarea strategiilor pedagogice alternative, care reduc sau elimină răspunsurile marcate de ruşine la copii (Monroe, 2009).

Facilitatori ai răspunsurilor marcate de ruşine identifica i în şcoală includ competi ia academică, cultivată în detrimentul cooperării, gruparea pe abilită i şi performan ă, tehnici necorespunzătoare de managementul clasei, ridiculizarea şi intimidarea practicată între colegi, dezinteresul, insensibilitatea sau ostilitatea cadrelor didactice. La acestea se adaugă atitudinea cadrelor didactice, dar şi a colectivului de elevi, fa ă de eşecul academic. Se impune aici, mai întâi, cultivarea la copii a unei cu totul alte perspective fa ă de ,a greşi” ca parte componentă a învă ării. 
În această perspectivă nu dorim să diminuăm răspunderea; copiilor ar trebui să li se solicite asumarea responsabilită ii pentru ac iunile lor; totuşi, aşa cum afirma Tangney şi Dearing (2002, p. 184), ,se pune accent pe comportament şi nu pe persoană". Mai concret, se recomandă evitarea tehnicilor de disciplinare şi de interac iune care se bazează pe ridiculizarea copilului, criticarea cu sensul diminuării şi inducerii ruşinii în condi ii publice pentru a controla comportamentul elevilor. Răspunderea pentru consecin ele faptelor este, de asemenea, un obiectiv al educa iei bazate pe dezvoltare, iar ruşinea şi vinovă ia în exces stimulează mai degrabă comportamente contrare.

\section{Referin e}

- Baumeister, R. F., Stillwell, A. M., \& Heatherton, T. F. (1994). Guilt: An interpersonal approach. Psychological Bulletin, 115(2), 243-267. https://doi.org/10.1037/0033-2909.115.2.243

- Chorpita, B. F., Ebesutani, C., \& Spence, S. H. (2015). Revised Children's Anxiety and Depression scale: users guide. http://www.childfirst.ucla.edu/RCADSUsersGuide20150701.pdf

- de Hooge, I., Zeelenberg, M., \& Breugelmans, S. (2007). Moral sentiments and cooperation: Differential influences of shame and guilt. Cognition \& Emotion, 21(5), 1025-1042. https://doi.org/10.1080/02699930600980874

- De Rubeis, S., \& Hollenstein, T. (2009). Individual differences in shame and depressive symptoms during early adolescence. Personality and Individual Differences, 46(4), 477-482. https://doi.org/10.1016/j.paid.2008.11.019

- Fergus, T., Valentiner, D., McGrath, P., \& Jencius, S. (2010). Shame- and guiltproneness: Relationships with anxiety disorder symptoms in a clinical sample. Journal of Anxiety Disorders, 24(8), 811-815. https://doi.org/10.1016/j.janxdis.2010.06.002

- Ferguson, T. J., Stegge, H., Miller, E. R., \& Olsen, M. E. (1999). Guilt, shame, and symptoms in children. Developmental Psychology, 35(2), 347-357. https://doi.org/10.1037/0012-1649.35.2.347

- Ferguson, T. J., Stegge, H., Eyre, H. L., Vollmer, R., \& Ashbaker, M. (2000). Context effects and the (mal)adaptive nature of guilt and shame in children. Genetic Social and General Psychology Monographs, 126(3), 319-345.

- Ferguson, T. J., Stegge, H., \& Damhuis, I. (1991). Children's understanding of guilt and shame. Child Development, 62(4), 827-839.

https://doi.org/10.2307/1131180

- Frick, P. J., \& White, S. F. (2008). Research Review: The importance of callous- 
unemotional traits for developmental models of aggressive and antisocial behavior. Journal of Child Psychology and Psychiatry and Allied Disciplines, 49(4), 359-375. https://doi.org/10.1111/j.1469-7610.2007.01862.x

- Friedberg, R. D., McClure, J. M., \& Garcia, J. H. (2013). Tehnici de terapie cognitivă pentru copii şi adolescen i. Instrumente pentru optimizarea practicii clinice. Editura ASCR.

- Ketelaar, T., \& Au, W. T. (2003). The effects of feelings of guilt on the behaviour of uncooperative individuals: An affect-as-information interpretation of the role of emotion in social interaction. Cognition and Emotion, 17(3), 429-453. https://doi.org/10.1080/02699930143000662

- Kim, S., Thibodeau, R., \& Jorgensen, R. S. (2011). Shame, guilt, and depressive symptoms: A meta-analytic review. Psychological Bulletin, 137(1), 68-96. http://dx.doi.org/10.1037/a0021466

- Lewis, H. B. (1971). Shame and guilt in neurosis. International Universities Press.

- Lindsay-Hartz, J., de Rivera, J., \& Mascolo, M. (1995). Differentiating shame and guilt and their effects on motivation. In J. P. Tangney \& K.W. Fischer (Eds.), Selfconscious emotions: Shame, guilt, embarrassment, and pride (pp.274-300). Guilford.

- Menesini, E., \& Camodeca, M. (2010). Shame and guilt as behaviour regulators: Relationships with bullying, victimization and prosocial behaviour. British Journal of Developmental Psychology, 26(2), 183-196.

http://dx.doi.org/10.1348/026151007X205281

- Monroe, A. (2009). Shame Solutions: How Shame Impacts School-Aged Children and What Teachers Can Do to Help. The Educational Forum, 73, 58-66.

- Novin, S., \& Rieffe, C. (2015). Validation of the Brief Shame and Guilt Questionnaire for Children. Personality and Individual Differences, 85, 56-59. http://dx.doi.org/10.1016/j.paid.2015.04.028

- Olthof, T. (2012). Anticipated feelings of guilt and shame as predictors of early adolescents' antisocial and prosocial interpersonal behaviour. European Journal of Developmental Psychology, 9(3), 371-388.

https://doi.org/10.1080/17405629.2012.680300

- Olthof, T., Schouten, A., Kuiper, H., Stegge, H., \& Jennekens-Schinkel, A. (2000). Shame and guilt in children: Differential situational antecedents and experiential correlates. British Journal of Developmental Psychology, 18(1), 51-64. https://doi.org/10.1348/026151000165562

- Orth, U., Berking, M., \& Burkhardt, S. (2006). Self-Conscious Emotions and Depression: Rumination Explains Why Shame But Not Guilt is Maladaptive. Personality and Social Psychology Bulletin, 32(12), 1608-1619. https://doi.org/10.1177/0146167206292958 
- Roos, S., Hodges, E. V., \& Salmivalli, C. (2014). Do guilt- and shame-proneness differentially predict prosocial, aggressive, and withdrawn behaviors during early adolescence? Developmental Psychology, 50(3), 941-946.

https://doi.org/10.1037/a0033904

- Roos, S., Salmivalli, C., \& Hodges, E. V. E. (2011). Person $\times$ context effects on anticipated moral emotions following aggression. Social Development, 20(4), 685-702. https://doi.org/10.1111/j.1467-9507.2011.00603.x

- Sheikh, S., \& Janoff-Bulman, R. (2009). The 'Shoulds' and 'Should Nots' of Moral Emotions: A Self-Regulatory Perspective on Shame and Guilt. Personality \& Social Psychology Bulletin, 36(2), 213-224.

https://doi.org/10.1177/0146167209356788

- Stănculescu, E. (2011). Self-reflexive emotions. Revista de Psihologie, 57(4), 340-348.

- Stuewig, J., Tangney, J. P., Kendall, S., Folk, J. B., Meyer, C. R., \& Dearing, R. L. (2015). Children's proneness to shame and guilt predict risky and illegal behaviors in young adulthood. Child psychiatry and human development, 46(2), 217227. https://doi.org/10.1007/s10578-014-0467-1

- Stuewig, J., Tangney, J. P., Heigel, C., Harty, L., \& McCloskey, L. (2010). Shaming, blaming, and maiming: Functional links among the moral emotions, externalization of blame, and aggression. Journal of Research in Personality, 44(1), 91-102. http://dx.doi.org/10.1016/j.jrp.2009.12.005

- Tangney, J. P., Stuewig, J., \& Mashek, D. J. (2007). Moral emotions and moral behavior. Annual Review of Psychology, 58, 345-372.

http://dx.doi.org/10.1146/annurev.psych.56.091103.070145

- Tangney, J. P., \& Dearing, R. L. (2002). Emotions and social behavior. Shame and guilt. Guilford Press. https://doi.org/10.4135/9781412950664.n388

- Tangney, J. P., Wagner, P. E., Hill-Barlow, D., Marschall, D. E., \& Gramzow, R. (1996). Relation of shame and guilt to constructive versus destructive responses to anger across the lifespan. Journal of Personality and Social Psychology, 70(4), 797-809. https://doi.org/10.1037//0022-3514.70.4.797

- Tangney, J. P., Miller, R. S., Flicker, L., \& Barlow, D. H. (1996). Are shame, guilt, and embarrassment distinct emotions? Journal of Personality and Social Psychology, 70(6), 1256-1264. https://doi.org/10.1037//0022-3514.70.6.1256

- Tangney, J. P., Wagner, P., Fletcher, C., \& Gramzow, R. (1992). Shamed into anger? The relation of shame and guilt to anger and self-re-ported aggression. Journal of Personality and Social Psychology, 62(4), 669-675.

https://doi.org/10.1037//0022-3514.62.4.669

- Tangney, J. (1990). Assessing Individual Differences in Proneness to Shame and Guilt: Development of the Self-Conscious Affect and Attribution Inventory. Journal of Personality and Social Psychology, 59(1), 102-111. 
https://doi.org/10.1037/0022-3514.59.1.102

- Tracy, J. L., Robins, R. W., \& Tangney, J. P. (Eds.). (2007). The self-conscious emotions: Theory and research. Guilford Press.

The online version of this article can be found at: http://revped.ise.ro/category/2020-en/

\section{(CC) $B Y-N C-B A$}

This work is licensed under the Creative Commons Attribution-NonCommercial-ShareAlike 4.0 International License.

To view a copy of this license, visit http://creativecommons.org/licenses/by-nc-sa/4.0/ or send a letter to Creative Commons, PO Box 1866, Mountain View, CA 94042, USA.
Versiunea online a acestui articol poate fi găsită la: http://revped.ise.ro/category/2020-ro/

\section{$( C C ) \longdiv { B r - N C - 3 A }$}

Această lucrare este licen iată sub Creative Commons Attribution-NonCommercial-ShareAlike 4.0 International License.

Pentru a vedea o copie a acestei licen e, vizita $i$ http://creativecommons.org/licenses/by-nc-sa/4.0/ sau trimite i o scrisoare către Creative Commons, PO Box 1866, Mountain View, CA 94042, SUA. 


\section{BOARD OF DIRECTORS:}

Researcher Mihai JIGĂU, PhD. Institute of

Educational Sciences, Romania

Prof. emeritus Viorel NICOLESCU, PhD.

University of Bucharest, Romania

Prof. Constantin CUCOȘ, PhD. "Alexandru

Ioan Cuza" University of lași, Romania
REVISTA

DE

PEDAGOGIE
JOURNAL

OF

PEDAGOGY

\section{EDITORIAL BOARD:}

Prof. Gabriel ALBU, PhD. Petroleum-Gas University of Ploiești, Romania

Researcher Otilia APOSTU, PhD. N.C.P.E.E. - E.R.U.*, Romania

Alexandru BOBOC, PhD. Romanian Academy

Researcher Laura Elena CĂPITĂ, PhD. N.C.P.E.E. - E.R.U.*, Romania

Prof. Carmen CRETTU, PhD. "Alexandru Ioan Cuza" University of lași, Romania

Lecturer Alina Narcisa CRIȘAN, PhD. Tehnical University of Cluj-Napoca, Romania

Senior lecturer Roxana ENÁCHE, PhD. Vice-President, Association "Teachers' Academy", Romania

Prof. Irfan ERDOGAN, PhD. University of Istanbul, Turkey

Prof. Natasha Angelska GALEVSKA, PhD. "Cyiril and Methodius" University of Skopje, Macedonia

Prof. Dimitrios B. GOUDIRAS, PhD. University of Macedonia, Thessaloniki, Greece

Researcher Atwell GRAHAM, PhD. University of Wales, United Kingdom

Researcher Irina HORGA, PhD. N.C.P.E.E. - E.R.U.*, Romania

Prof. Violeta MIRCHEVA, PhD. National Institute of Education, Bulgaria

Prof. Ioan NEACŞU, PhD. University of Bucharest, Romania

Prof. Rodica NICULESCU, PhD. "Transilvania" University of Brașov, Romania

Prof. Aleksandra PEJATOVIC, PhD. University of Belgrad, Serbia

Prof. Rossitsa PENKOVA, PhD. "K. Ohridski" University of Sofia, Bulgaria

Lecturer Ana-Maria Aurelia PETRESCU, PhD. "Valahia" University of Târgoviște, Romania

Prof. Dan POTOLEA, PhD. University of Bucharest, Romania

Prof. Athina SIPITANOU, PhD. University of Macedonia, Thessaloniki, Greece

Prof. Emil STAN, PhD. Petroleum-Gas University of Ploiești, Romania

Acad. Alexandru SURDU, Romanian Academy

Prof. Nikos TERZIS, PhD. "Aristotle" University of Thessaloniki, Greece

Researcher Simona Luciana VELEA, PhD. N.C.P.E.E. - E.R.U.*, Romania

Prof. Pavel ZGAGA, PhD. University of Ljubljiana, Slovenia

${ }^{*}$ National Center for Policy and Evaluation in Education - Education Research Unit

\section{ISSUE COORDINATORS:}

Researcher Oana IFTODE, Researcher Ancuța PLĂEȘU, PhD

\section{EDITOR:}

Miruna Luana MIULESCU

\section{GRAPHIC DESIGNER AND DTP:}

Vlad PASCU

\section{JOURNAL BINDING:}

Constantin CHIȚU

Print ISSN: 0034-8678

Online ISSN: 2559-639X

Indexing: CEEOL, Citefactor, Crossref, De Gruyter (IBZ and IBR), DOAJ, EBSCO, ERIH Plus, Google Academic and Ulrichweb. The articles on Higher Education can also be indexed in HEDBIB.

The information and views set out in the published contributions are those of the author(s) and do not necessarily reflect the official opinion of the Journal of Pedagogy.

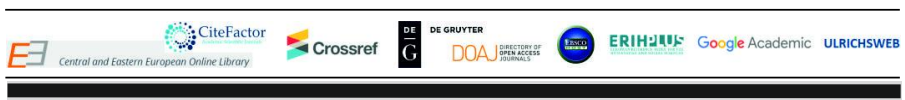

CONTACT: 37 Ştirbei Vodă Street, sector 1, Bucharest 010102

Tel.: 004021 314.27.83 Fax: 004021312.14 .47

E-mail: revped@ise.ro Webpage: http://revped.ise.ro

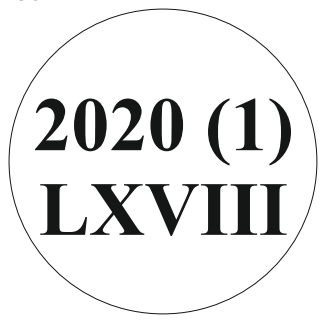




\section{STIMAȚI CITITORI,}

Revista de pedagogie își propune, ca și până acum de altfel, să popularizeze rezultatele cercetării științifice în domeniul educației la nivel național și internațional, să dezbată puncte de vedere și aspecte de actualitate din domenii precum management școlar, curriculum, evaluare, educație permanentă, consilierea și orientarea carierei. Revista contribuie astfel la facilitarea schimbului de experiență și la consolidarea pregătirii riguroase și consecvente a resurselor umane din domeniul educației.

Revista de pedagogie reprezintă o sursă valoroasă de documente care trebuie să facă parte din biblioteca profesorilor, a tinerilor care se pregătesc pentru cariera didactică și a celor interesați de progresele, direcțiile de dezvoltare, inovațiile și bunele practici în domeniul educațional.

Vă informăm că redacția dispune, pentru consultare, de colecția Revistei de pedagogie pe anii 1995-2015, precum și, pentru vânzare, de diferite numere din perioada 2010-2019.

Pentru informații suplimentare privind prețul unui exemplar al Revistei de pedagogie și modalitățile de achiziționare vă stăm la dispoziție la sediul revistei din strada Știrbei Vodă nr. 37, sector 1, București, tel.: 021-3142783, e-mail: revped@ise.ro, http://revped.ise.ro.

Vă mulțumim,

REDACTIIA

\section{Revista de Pedagogie/Journal of Pedagogy $2020(1) \cdot$ LXVIII \\ Print ISSN: 0034-8678 \\ Online ISSN: 2559-639X}

